Illinois State University

ISU ReD: Research and eData

Theses and Dissertations

$9-27-2013$

\title{
Discursive Tactical Negotiations within and across Literacy Coaching Interactions
}

Carolyn S. Hunt

Illinois State University, cshunt@ilstu.edu

Follow this and additional works at: https://ir.library.illinoisstate.edu/etd

Part of the Teacher Education and Professional Development Commons

\section{Recommended Citation}

Hunt, Carolyn S., "Discursive Tactical Negotiations within and across Literacy Coaching Interactions" (2013). Theses and Dissertations. 36.

https://ir.library.illinoisstate.edu/etd/36

This Dissertation is brought to you for free and open access by ISU ReD: Research and eData. It has been accepted for inclusion in Theses and Dissertations by an authorized administrator of ISU ReD: Research and eData. For more information, please contact ISUReD@ilstu.edu. 


\title{
DISCURSIVE TACTICAL NEGOTIATIONS WITHIN AND ACROSS LITERACY COACHING INTERACTIONS
}

\author{
Carolyn S. Hunt
}

259 Pages

December 2013

In this dissertation, the researcher employed de Certeau's theoretical insights into cultural production in everyday life to examine how literacy coaches and teachers discursively negotiated issues of identity, power, and positioning during coaching interactions. The study also explored how literacy coaches and teachers enacted emotions within these discursive negotiations of identity, power, and positioning; and how physical, social, and ideological spaces were shaped by and reflected in coaching interactions. Data were generated during a yearlong qualitative study of literacy coaches and teachers interacting within a mid-size, suburban district in the U.S. Midwest. The researcher used a microethnographic approach to discourse analysis to closely examine brief, video-recorded interactions between coaches and teachers. Other data sources included semi-structured interviews, field observations, and artifact collection. Findings demonstrate how dominant Discourses of best practices, teacher development, collaboration, and coaches' credibility were simultaneously reproduced, resisted, and appropriated within the coaching interactions. Coaches and teachers interacted within 
conditions of vulnerability as they attempted to maintain identities as "good" coaches and teachers and negotiated understandings of what professional learning means, what counts as relevant knowledge for instructional decision making, and who decides. These

findings may encourage coaches and teachers, as well as administrators and educational policy makers, to acknowledge the multiplicities, uncertainties, and ambiguities of professional development and to incorporate less dominant ways of knowing and being into professional learning communities. 
DISCURSIVE TACTICAL NEGOTIATIONS WITHIN AND ACROSS

LITERACY COACHING INTERACTIONS

CAROLYN S. HUNT

A Dissertation Submitted in Partial

Fulfillment of the Requirements

for the Degree of

DOCTOR OF EDUCATION

School of Teaching and Learning

ILLINOIS STATE UNIVERSITY

2013 
(C) 2013 Carolyn S. Hunt 
DISCURSIVE TACTICAL NEGOTIATIONS WITHIN AND ACROSS LITERACY COACHING INTERACTIONS

CAROLYN S. HUNT

COMMITTEE MEMBERS:

Lara J. Handsfield, Chair

Deborah MacPhee

Thomas P. Crumpler

Lisya Seloni 


\section{ACKNOWLEDGMENTS}

I would like to thank the many people who have supported and encouraged me throughout my doctoral studies. This dissertation would not be possible without them. First and foremost, I thank the participants in this study, who graciously opened their schools, classrooms, and lives and allowed me to observe and participate in their daily work.

I extend my deepest thanks to my adviser, Lara Handsfield, who I feel lucky to call a mentor and friend. She constantly pushed me to say more and to delve deeper, and this work is better because of her encouragement and guidance. More importantly, she warmly welcomed me into the academic world by inviting me to writing groups, supporting my research, informing me about conferences, and introducing me to other literacy researchers. She treated me as a colleague, which has built my confidence as a literacy researcher and writer. I am truly grateful and hope that our relationship will extend well into the future.

I am also grateful to my committee members, whose insights and support have been invaluable. Deborah MacPhee's readings and comments, based on her experiences as a literacy coach, have helped me to balance theory and practice and to push myself to communicate to a wider audience. Also, she has been a great listener throughout this

process, and I have enjoyed all of our lunches together. Thanks to Thomas Crumpler for 
involving me in his research and inviting me to write and present with him. Thanks to Lisya Seloni, the first person who helped me to see myself as an emerging scholar and whose research has been an inspiration.

My sincerest appreciation goes to my family. I want to thank my grandparents, who provided stability and love in a chaotic world. They are the bedrock of all happiness and success in my life, and I would not be who I am today without their nurturing guidance. Love and thanks to my mother, who has always been a true friend and has spent many hours listening to my struggles and worries as I strived to complete this project. Finally, I thank my husband, Jonathan, whose pride and belief in me are unwavering. Throughout the process of writing this dissertation, he was always willing to listen to my philosophical ramblings, and our discussions enhanced my analyses and interpretations.

I dedicate this dissertation to my grandfather, who always made me feel like I could do anything. 


\section{CONTENTS}

\section{Page}

ACKNOWLEDGEMENTS

CONTENTS

iii

TABLES

viii

FIGURES

ix

\section{CHAPTER}

I. INTRODUCTION

Statement of the Problem 3

$\begin{array}{lr}\text { Research Questions } & 6\end{array}$

$\begin{array}{ll}\text { Theoretical Framework } & 7\end{array}$

De Certeau and the Practice of Everyday Life $\quad 7$

Discourses $\quad 9$

Social Positioning $\quad 11$

Situated Identities $\quad 12$

Emotions as Discursive Negotiations $\quad 14$

$\begin{array}{ll}\text { Considering Space } & 15\end{array}$

$\begin{array}{ll}\text { Significance } & 17\end{array}$

$\begin{array}{ll}\text { Overview of Chapters } & 18\end{array}$

$\begin{array}{ll}\text { II. REVIEW OF LITERATURE } & 20\end{array}$

Philosophical Foundations of Literacy Coaching 21

Literacy Coaching Models $\quad 21$

Peer coaching $\quad 22$

Technical coaching 23

Cognitive coaching 25

Informal literacy coaching $\quad 26$ 
Literacy Coaching and Vygotsky 28

The Literacy Coach as Expert 30

Positioning Teachers through Literacy Coaching 35

Literacy Coaching and Identity 38

Limitations of Existing Research $\quad 41$

Considering Literacy Coaching as Spatialized Practice $\quad 41$

Considering Emotions $\quad 42$

$\begin{array}{ll}\text { Summary } & 44\end{array}$

III. RESEARCH DESIGN 46

Research Paradigm 46

The Discursive Co-Construction of Selves and Others $\quad 47$

Truth, Knowledge, and Power 48

A Microethnographic Approach to Discourse Analysis 49

Research Setting $\quad 52$

Participants 53

Researcher Positionality $\quad 57$

$\begin{array}{ll}\text { Data Sources } & 60\end{array}$

Observations $\quad 62$

Video Recorded Observations 65

Semi-structured Interviews $\quad 67$

Artifacts $\quad 69$

$\begin{array}{ll}\text { Research Journal } & 70\end{array}$

$\begin{array}{ll}\text { Data Analysis } & 70\end{array}$

$\begin{array}{ll}\text { Phase One } & 71\end{array}$

Phase Two $\quad 76$

$\begin{array}{ll}\text { Phase Three } & 78\end{array}$

$\begin{array}{ll}\text { Trustworthiness } & 79\end{array}$

Thick Description $\quad 80$

Triangulation $\quad 80$

Member Checking $\quad 81$

$\begin{array}{ll}\text { Peer Debriefing } & 82\end{array}$ 
$\begin{array}{lr}\text { Ethical Considerations } & 84\end{array}$

$\begin{array}{ll}\text { Summary } & 85\end{array}$

IV. LITERACY COACHING IN THE LOCAL CONTEXT 86

$\begin{array}{ll}\text { Local Expectations for Literacy Coaching } & 87\end{array}$

$\begin{array}{ll}\text { Purposes of Literacy Coaching } & 87\end{array}$

$\begin{array}{ll}\text { Coaching Tasks } & 89\end{array}$

Mentoring $\quad 89$

Modeling $\quad 89$

Observations and feedback $\quad 90$

Resources 91

Conversation 93

Providing professional development 94

Data management 95

Interventions 95

Discussion of Dominant Discourses within the Coaches' Work 96

$\begin{array}{lr}\text { Best Practices } & 96\end{array}$

Valued local practices $\quad 97$

Best practices as a de facto mission and vision $\quad 98$

Counter Discourses 100

$\begin{array}{ll}\text { Development } & 101\end{array}$

Professional development and best practices $\quad 102$

Stage model of teacher development 103

Sociocultural cognitive development 104

$\begin{array}{ll}\text { Credibility } & 106\end{array}$

$\begin{array}{ll}\text { Expertise } & 106\end{array}$

$\begin{array}{ll}\text { Trust } & 107\end{array}$

$\begin{array}{ll}\text { Collaboration } & 108\end{array}$

$\begin{array}{ll}\text { Summary } & 110\end{array}$ 
$\begin{array}{ll}\text { Special Education Team Meeting } & 114\end{array}$

Nina's Small Story 118

Teachers' Request for Localization and Relevance 126

Planning Meeting with Tiffany 129

Reflection Meeting with Luke 138

$\begin{array}{ll}\text { Summary } & 149\end{array}$

VI. COACHING INTERACTIONS AT WESTFIELD PRIMARY SCHOOL 152

Conversation with Katie 154

Reflection Meeting with Sophie 167

$\begin{array}{ll}\text { Summary } & 179\end{array}$

VII. COACHES AND TEACHERS AS FRAGMENTED SELVES 181

The Commodification of Best Practices 182

The Productive Consumption of Best Practices 185

Selling Best Practices 186

Tactical Positionings within the Discourse of Development 187

Development and Best Practices $\quad 188$

A Stage Model of Development 189

The ZPD and Deficit Positionings 190

Constructing Identities as "Good" Teachers and Coaches 192

Conditions of Vulnerability 194

Norms of Collaboration and "Making Nice" 196

Summary 198

$\begin{array}{ll}\text { VIII. CONCLUSION } & 199\end{array}$

$\begin{array}{ll}\text { Summary of Findings } & 200\end{array}$

Research Question $1 \quad 200$

Research Question 2

Research Question $3 \quad 204$

Limitations 206

Implications for Practice 208 
The Consumption and Production of Knowledge 208

Development as Breaking Away 211

Trust within Spaces of Discomfort and Ambiguity 212

Emotional Ways of Knowing 214

Implications for Research 216

Research on Literacy Coaching 216

Microethnographic Research 218

$\begin{array}{ll}\text { Final Thoughts } & 219\end{array}$

$\begin{array}{ll}\text { REFERENCES } & 221\end{array}$

APPENDIX A: Research Journal Entry 255

APPENDIX B: Transcript Conventions $\quad 257$

APPENDIX C: Full Transcript of Special Education Meeting 259 


\section{TABLES}

Table $\quad$ Page

$\begin{array}{lll}2.1 & \text { Coaching Models } & 22\end{array}$

3.1 Participant Information 56

$\begin{array}{lll}3.2 & \text { Research Timeline }\end{array}$

3.3 Video Recordings 66

3.4 Teacher Interviews $\quad 68$

3.5 Themes, Categories, and Grounded Codes 72

5.1 Sub-events within the Special Education Meeting 116

5.2 Transcript of Nina's Small Story 119

5.3 Transcript of Teachers' Request for Localization and Relevance 126

5.4 Transcript of Segment One of Planning Meeting with Tiffany 130

5.5 Transcript of Segment Two of Planning Meeting with Tiffany 133

5.6 Transcript of Reflection Meeting with Luke 139

6.1 Transcript of the Conversation with Katie 157

6.2 Transcription of Reflection Meeting with Sophie 170 


\section{FIGURES}

Figure $\quad$ Page

6.1 Reflecting Conference Guide

176

ix 


\section{CHAPTER I}

\section{INTRODUCTION}

As a second grade teacher from 2001-2008, I spent most of my tenure enacting the common "closed-door policy." Like many teachers, I believed that it was sufficient to shut my classroom door and do the best I could for my students based on what I knew about literacy and learning. I was passionate about providing the best possible literacy instruction throughout the day for my students, and I was content to do so without the prying eyes of others or the intrusion of educational policies that were outside of my control. I concentrated on ensuring that all of my students were able to read and write proficiently by the end of their time with me and that they developed less measurable qualities such as critical thinking and self motivation to learn.

Over time, however, I began to see problems with this approach to teaching. First, although I collaborated with the other second grade teachers, there was an overall lack of collaboration within our school, which led to uneven quality of instruction across grade levels. I became concerned that it wasn't enough for a student to have a successful second grade year. They needed teachers that worked and learned together in order to ensure a whole-system quality learning environment and comprehensive literacy instruction (Fishman, Marx, Best, \& Tal, 2003; Fullan, 2011). Furthermore, increasing policy pressures brought on by the implementation of No Child Left Behind (No Child Left Behind [NCLB], 2002) made shutting my door and ignoring policy initiatives much more 
difficult. My colleagues and I were told to implement curriculum and instructional methods in our classrooms that did not align with our instructional goals or the needs of our students. Students who needed the most support from qualified teachers were pulled from the classroom literacy block in order to work with instructional aides or parent volunteers using prepackaged, scripted programs.

This series of events inspired me to encourage and support collaborative learning and problem solving among teachers in an effort to provide the best possible environment for students' literacy learning. I wanted to be a part of ensuring that all students have a quality teacher and that all teachers have the resources and support necessary to provide high quality literacy instruction. As such, I began to organize and participate in professional book studies and to actively seek opportunities to mentor interns and novice teachers. Based on these experiences, I decided to leave my position as a second grade teacher to work as a reading specialist and literacy coach. I began by joining the newly formed staff of an inner-city middle school housed in a high school that was in the process of restructuring to meet NCLB (2002) requirements. I spent two class periods per day working with seventh and eighth graders identified as struggling readers and the rest of the day co-planning and co-teaching with language arts, social studies, and science teachers.

After a year, I moved on to be a literacy coach in a primary school in a midsize suburban district. I spent the majority of my day working with small groups of second and third graders and conducting Reading Recovery lessons with first graders. Although my job responsibilities included supporting teachers in their professional learning, teachers at the school were less comfortable with my presence in their classroom. 
Therefore, my contributions to the professional learning community were directed mostly at assisting in the planning of in-service professional development days and assisting with the Response to Intervention process. These experiences opened my eyes to the complexities and situated nature of literacy coaching. At the same time, literacy coaching was often a rewarding experience that I still believe holds possibilities for decreasing teacher isolation and promoting collaborative professional learning.

\section{Statement of the Problem}

My concern for providing quality professional learning spaces for teachers aligns with current educational agendas that heavily emphasize the importance of highly qualified teachers for improving student achievement (NCLB, 2002). The need for more increased professional development is further supported through policies such as Race to the Top (2009), which encourages districts competing for federal grant money to provide supports to teachers and principals in an effort to enhance teacher effectiveness and improve student achievement (Goldrick, Osta, \& Maddick, 2010). It is increasingly recognized that, in order to implement effective instruction, teachers need ongoing support and professional development rather than isolated in-service trainings through one-shot workshops (International Reading Association, 2004).

To this end, many educational researchers have argued that it is important to move beyond a traditional, linear model of professional development which envisions professional learning as the transmission of knowledge and skills from an outside expert to the teacher (Cochran-Smith \& Lytle, 2006; Elmore, 2002; Fenwick, 2003; Hawley \& Valli, 1999; Newmann, King, \& Youngs, 2000; Richardson \& Placier, 2001). Rather, professional development is most effective when it involves ongoing learning by teachers 
and administrators in the context of collaborative problem solving (Hawley \& Vali, 1999). Furthermore, professional development has been found to be more advantageous when it is conducted on site and is closely associated with teachers' classroom practice (Elmore, 2002). As literacy coaches Burkins and Ritchie (2007) argued, "Professional learning is not simply a workshop we attend, but something we live daily within the walls of our schools and in the classrooms of the teachers with whom we work" (p. 33).

In an effort to respond to increasing pressures to ensure a quality education for all and to act on these principles of effective professional development, many districts have implemented literacy coaching to provide support for teachers' professional learning. Literacy coaching is a promising method for meeting such goals for several reasons (International Reading Association, 2004). First, literacy coaches can work with teachers in the context of the classroom and give teachers the opportunity to see students react in real time to new instructional methods (Poglinco et al., 2003). Secondly, literacy coaching is a powerful vehicle for establishing and sustaining collaborative professional learning communities (Collet, 2012; Matsumura, Garneier, Correnti, Junker, \& Bickel, 2010). In addition, literacy coaching has the potential to develop professional learning opportunities that develop around the concerns that matter to teachers as opposed to topdown initiatives and may support the development of complex understandings over time (Crafton \& Kaiser, 2011). Furthermore, literacy coaching can be an effective way of promoting teacher reflection and dialogic relationships or "knowledge-building partnerships" (Robb, 2000, p. 52), which allow for deeper thinking and professional growth (Burkins \& Ritchie, 2007; Joyce \& Showers, 2002). 
Despite the promising characteristics of literacy coaching, many researchers have highlighted the challenges associated with implementing this emerging form of professional development (Bean, Draper, Hall, Vandermolen, \& Zigmond, 2010; Blamey, Meyer, \& Walpole, 2009; Buell, Han, Blamey, \& Vukelich, 2010; Gibson, 2006; Lynch \& Ferguson, 2010; Mraz, Algozzine \& Watson, 2008; Rainville \& Jones, 2008; Otaiba, Hosp, Smartt, \& Dole, 2008; Peterson, Taylor, Burnham, \& Schock, 2009; Walpole \& Blamey, 2008). One of the most commonly documented barriers to coaching is lack of time to work with teachers in the classroom (Blamey et al., 2009; Duessen, Coskie, Robinson, \& Autio, 2007; Lynch \& Ferguson, 2010; Mraz et al., 2008; Walpole \& Blamey, 2008). Another common concern is the lack of a clear job description and difficulty with defining literacy coaches' roles (Deussen et al., 2007; Steckel, 2009; Walpole \& Blamey, 2008). Other researchers have noted the complexities of literacy coaching such as shifting positions and identities across contexts (Rainville \& Jones, 2009) and the importance of balancing policy demands with the needs of teachers and students (Coburn \& Woulfin, 2012; MacGillivray, Ardell, Curwen, \& Palma, 2004).

I experienced many of these challenges during my work as a literacy coach in two different environments. Moreover, the challenges were quite different in each of the two schools, and different strategies were necessary for building trusting, collaborative relationships with teachers and administration. Similarly, literacy coaches involved in a previous study I conducted (Hunt \& Handsfield, 2013) wrestled with the challenges of literacy coaching differently depending on the contexts of their individual schools and their past experiences with the teachers with whom they worked. These experiences highlighted for me how contextualized literacy coaching is. It is difficult to follow a how- 
to guide for literacy coaching because no one guide or set of advice is sufficient for every coaching context or situation. Rather, coaching is highly dependent on the school contexts as well as on the coaches' relationships with individual teachers. Therefore, a coach's work may differ from district to district, from school to school, or even from classroom to classroom. Such variance contributes to the political, moral, and emotional complexities of literacy coaching, yet little attention has been paid to these issues in the existing research. Thus, as a field, we have little understanding of how these complexities play out in interactions between coaches and teachers.

\section{Research Questions}

The complexity and fluidity of literacy coaching that I witnessed in my own practice and in the practice of other literacy coaches led me to the questions addressed in the current study. I examined the complexities of coaches' daily work in an effort to understand their in-the-moment interactions with teachers across institutional spaces and over time. I asked the following overarching question: How do literacy coaches and teachers discursively negotiate issues of identity, power, and positioning during coaching interactions? Based on previous work examining these issues among first-year literacy coaches (Hunt \& Handsfield, 2013), I also explored the following secondary research questions:

1. How do literacy coaches and teachers enact emotions in their discursive negotiations of identity, power, and positioning?

2. How are physical, social, and ideological spaces shaped by and reflected in interactions between literacy coaches and teachers? 
My exploration was informed by a poststructural theoretical framework based in the work of de Certeau (1984) and others (Davies \& Harré, 1990; Foucault, 1980; Gee, 2011a; Zembylas, 2005b). This theoretical framework informed every step of the research process, so I will begin by outlining the primary understandings and theoretical constructs that influenced my decision making and interpretations throughout the study.

\section{Theoretical Framework}

In this section, I explain how I draw on the work of de Certeau (1984) and others to consider issues of identity, power, and positioning in literacy coaching interactions. First, I outline the major tenets of de Certeau's (1984) theories about everyday practice that informed this study. Next, I expand on de Certeau by integrating his ideas with theories about identity, positioning, and the co-construction of meaning through social interaction. For instance, I clarify my use of the term Discourses and highlight the importance that language and semiotics play in the social construction of the world, the self, and others. Next, I acknowledge the situated nature of peoples' co-constructions of identities and the ways in which they position themselves in relation to Discourses. I further highlight how people discursively enact emotions as they negotiate their identities and social positions. Finally, I argue that it is important to fully consider the spatial contexts in which people perform these discursive negotiations.

\section{De Certeau and the Practice of Everyday Life}

De Certeau (1984) highlighted how ordinary people use tactics within everyday practices to negotiate power, co-construct space, and reposition themselves. Tactics, such as specific rhetorical devices, can be intentional and premeditated. In other cases, individuals may not be fully aware of how they tactically negotiate issues of power, 
positioning, and identity through their discursive moves. de Certeau called these everyday, discursive negotiations "the art of speaking" (p. 24) in which people "dance their way to spontaneous creations of new meaning" (Hartnett, 1998, p. 286). This tacit dance opens up possibilities for reimagining spaces and boundaries and allows for a degree of agency as people tactically negotiate meanings and act upon existing spaces and Discourses (Bloome, Carter, Christian, Otto, \& Shuart-Farris, 2005; Handsfield, Crumpler, \& Dean, 2010; Hunt \& Handsfield, 2013). Bucholtz and Hall (2004) described such negotiations as "tactics of intersubjectivity" or "the local, situated, and often improvised quality of the everyday practices through which individuals, though restricted in their freedom to act by externally imposed constraints, accomplish their social goals" (p. 382).

De Certeau (1984) defined strategies, on the other hand, as the calculations of powerful institutions used to define a "proper" place from which to gain control over subjects. Strategies "create places in conformity with abstract models" (p. 29) and "are actions which, thanks to the establishment of a place of power (the property of a proper), elaborate theoretical places (systems and totalizing discourses) capable of articulating an ensemble of physical places in which forces are distributed" (p. 38). Within literacy coaching, "abstract models" such as coaching roles or conceptions of universal "best practices" could be considered strategies for controlling professional learning and ensuring that coaches and teachers work towards mandated policy initiatives (Hunt \& Handsfield, 2013).

De Certeau's (1984) ideas about production and consumption are also relevant to the work of literacy coaches and teachers. He explained the many "poetic ways of 
making do" by people who are less powerful. Rather than simply consuming a production of the dominant order, everyday people appropriate products and manipulate them for their own purposes. Thus, consumption is "devious, it is dispersed, but it insinuates itself everywhere, silently and almost invisibly, because it does not manifest itself through its own products, but rather through its ways of using the products imposed by a dominant economic order" (p. xii-xiii). In terms of literacy coaching, it is important to consider how coaches and teachers consume educational materials or policies and appropriate them for their own purposes.

\section{Discourses}

Tactics, strategies, and productive consumption occur in relation to the Discourses circulating within local and global contexts. Since the term discourse can have different meanings depending on the field of study and the researcher's theoretical framework, it is important to clearly define the conceptualization of discourse that informs this study. I draw on an understanding of Discourse that looks beyond the basic linguistic aspects of language in use to consider the cultural models that people construct through language and other semiotic tools as they interact in the world (Bloome et al., 2005; Gee, 2011a; Volosinov, 1973; Wodak \& Kroger, 2000). Gee (2011a) referred to these cultural models as Big "D" Discourses, which he defined as "ways of combining and integrating language, action, interactions, ways of thinking, believing, valuing, and using various symbols, tools, and objects to enact a particular sort of socially recognizable identity" (Gee, 2011a, p. 201). Big “D” Discourses are different from, but include, little "d" discourses, which he defined as "language in use or connected stretches of language that make sense, like conversations, stories, reports, arguments, essays, and so forth" (p. 154). 
He argued that people perform "socially situated identities" (Gee, 2012, p. 3) as they act in ways that allow them to be recognized as "certain kinds of people" (Gee, 2004, p. 85) within particular Discourse communities. These Discourses are multiple in that people work within and across a variety of Discourses. They are fluid in that they can be split or melded together, can change over time, emerge or die out, and have contestable boundaries (Gee, 2011a).

I understand Discourses as strongly affected by both local contexts and broader ideologies within society. This understanding is influenced by the work of Foucault, who defined Discourses as "practices which systematically form the objects of which they speak" (Foucault, 1972, p. 49). In other words, "ways of constituting knowledge, together with the social practices, forms of subjectivity and power relations which inhere in such knowledges and relations between them" (Weedon, 1987, p. 108). He argued that society is reproduced through "regimes of truth," which are "the types of discourse which it accepts and makes function as true" (Foucault, 1980, p. 131). He articulated several traits of the dominant discourses within Western societies. First, truth is defined in terms of scientific discourse. Secondly, truth is used for "economic production and political power" (Weedon, 1987, p. 131). Moreover, truth is widely distributed and consumed under the control of a few dominant institutions and its nature and content are influenced by constant ideological struggles.

My understanding of Big D Discourses is further influenced by the concept of intertextuality (Bakhtin, 1981; Kamberelis \& Scott, 1992; Kristeva, 1980; Lemke, 1992). As Lemke (1992) explained, "Every text, the discourse of every occasion, makes its social meanings against the background of other texts, and the discourses of other 
occasions" (p. 257). In this sense, any meaningful artifact can be considered a text whether it consist of written discourses, spoken interactions, or other modes of communication (Kamberelis \& Scott, 1992). Bakhtin (1981) described every text as a heterglossia in which multiple Discourses, or voices, are expressed as people draw on what has come before and on social expectations in order to co-construct dynamic descriptions and understandings of the world. Within these dialogic constructions, multiple systems of meaning are present and there are a variety of possibilities for response as "people borrow and transform others' voices in order to construct their own utterances" (Kamberelis \& Scott, 1992, p. 363). Furthermore, Bakhtin (1981) argued that these heteroglossic, intertextual Discourses are never neutral but that each present voice represents ideologies and dominant Discourses. For literacy coaches, this means that their social positions, their situated identities (Gee, 1999), are co-constructed with others in relation to Discourses within the local professional community and to more global Discourses of literacy, research, collaborative professional learning, and educational policies (Crafton \& Kaiser, 2011; Coburn \& Woulfin, 2012; Hunt \& Handsfield, 2013; MacGillivray et al., 2004).

\section{Social Positioning}

People position themselves and others in relation to Discourses. Harré (2010) defined a position as "a cluster of rights and duties recognized in a certain social milieu" and positioning as "the corresponding act by which a person claims certain rights and opts for certain duties, or has them thrust on a certain social actor" (p. ix). These positions are acted out according to personal attributes, moral orders, and the expectations of others (Tan \& Moghaddam, 1999; van Langenhove \& Harré, 1999). 
Positions are dynamic and fluid as speakers engage in the discursive construction of personal stories that make a person's actions intelligible and relatively determinate as social acts" (Harré \& van Langenhove, 1999, p. 17). In other words, positioning is a discursive process by which speakers locate themselves within a jointly constructed story line (Harré \& Davies, 1992). Furthermore, there are multiple possible positions that people may take up or resist within any given social context (Harré \& van Langenhove, 1999).

Thus, positioning theory recognizes fluidity and affords opportunities for researchers to observe the small, in-the-moment interactional moves that people make as they co-construct stories about who has the right to be heard by whom in which contexts and as they negotiate meanings in relation to local contexts and dominant Discourses. Such a viewpoint allows for a closer examination of the complexities of learning and literacy coaching, a fuller exploration of culturally situated practice, and insight into the power relations inherent within particular positions taken up in real-world interactions (McVee, 2010). Within literacy coaching, attention to social positioning pushes researchers to examine how power works within and around the relationships between coaches and teachers. Furthermore, social positioning is intricately related to coaches' and teachers' co-construction of identities as the positions we take up and are given say volumes about what kind of person we want and are expected to be (Davies \& Harré, 1990, 1999).

\section{Situated Identities}

Situated identities are closely related to social positionings. Gee (1999) argued that people enact "situated identities," by which he meant that they enact different 
identities based on who they are communicating with, when and where they are communicating, and the practices of communication that are acceptable in that context. This view calls for a dynamic understanding of identities as shifting and multiple (Bucholtz \& Hall, 2004; Gee, 2001; Moje \& Luke, 2008). Identity is not viewed as a fixed, individual entity. Rather, as Moje and Luke (2008) explained, “one person might enact many different identities, both across a developmental trajectory or within a variety of different contexts" (p. 418). This multiplicity of identities draws on, but is not fully determined by, a large variety of social contexts such as race, gender, age, class, religion, etc.

In addition, I understand identities as socially co-constructed through the negotiations of everyday interactions (Bloome et al., 2005; Bucholtz \& Hall, 2004; Erickson, 2004; Gee, 2001; Moje \& Luke, 2009). Identities are created through others' recognition of "a certain kind of person" (Gee, 2001). As Moje and Luke (2009) stated, a "person is called into an identity by the recognitions or assignments of others, and the meanings the person makes of the identities available to him or her serve to constitute a sense of self or subjectivity" (p. 419). This set of available meanings depends on local and global contexts in which people live and work. Furthermore, these co-constructed identities are affected by the micro-level workings of social interactions and the macrolevel forces of dominant Discourses. For literacy coaches, the conception of situated identities means that they are not limited to one static identity such as expert or colearner. Rather, their interactions with teachers are performed within a multiplicity of identities which are rooted in, but not fully determined by, a variety of social contexts such as class, race, age, gender, religion, job assignment, and the like. 


\section{Emotions as Discursive Negotiations}

Literacy coaching involves complex emotional work within emotional landscapes, or the physical and ideological spaces that "shape and are shaped by the literacy coaches' [and teachers'] enactments of emotions" (Hunt \& Handsfield, 2013, p.71). Within positioning theory, emotions can be seen as discursive acts, and as such, it is important to consider both what emotions are expressed in a social interaction and how they are used to negotiate issues of identity, power, and positioning. In this study, I view emotions as socially co-constructed discursive acts that are intricately related to identities (Denzin, 1984; Haviland-Jones \& Kahlbaugh, 2000; Harrè, 1986; Schutz \& Zembylas, 2009; Zembylas, 2005b). Within this perspective, emotions index how we view ourselves, our positions within local and global contexts, and how we want to be recognized by others (Bamberg, 1997; Gunthner, 1997; Solomon, 1993). Emotions are performed and co-produced as people “do emotions” (Zembylas, 2005b, p.211) and cannot be separated from enactments of social identities (Cross \& Hong, 2009; HavilandJones \& Kahlbaugh, 2000; Meyer, 2009; Zembylas, 2005b).

Furthermore, emotions can be a means for positioning ourselves and others within a moral order because their expression can indicate acceptance or disproval of the current situation (Parrott, 2003). Similar to Discourses, "emotional rules" develop based on what emotional displays are considered acceptable within a particular context (Zembylas, 2005a). These rules govern and limit the power of emotional expressions, but may be resisted when emotions are used as tactics for resisting and negotiating social expectations (Zembylas, 2005a). This discursive use of emotions is not necessarily intentional but is performed within moment-to-moment interactions between the self and 
others (Davies \& Harré, 1990; Erickson, 2004). As Davies and Harrè (1990) explained, "It would be a mistake...to assume that positioning is necessarily intentional. One lives one's life in terms of one's ongoingly produced self' (p. 48).

\section{Considering Space}

In addition to discursive theories of emotion, I drew on the work of Lefebvre (1991), deCerteau (1984), and others (Sheehy \& Leander, 2004; Soja, 2004) to conceptualize space as lived and practiced. Within this view, space is seen as socially constructed and changeable rather than as a fixed geographical point on a map. Thus, institutional spaces such as classrooms are more than just the physical space enclosed within their walls and are made up of the interactions occurring within and around them over time. Spaces are not always physical but may also consist of the "imagined geographies that shape our lives in various ways" (Soja, 2004, p. x). For example, literacy coaches interact not only in classrooms but also within the confines of intangible spaces such as school literacy models or the relationships formed with colleagues.

As de Certeau (1984) pointed out, there is a difference between space and place. He defined place as a fixed location that is governed by the "law of the proper" in which "the elements" such as buildings or classrooms are "beside one another, each situated in its own 'proper' and distinct location" (p. 117). He argued that place "implies an indication of stability" (p. 117). He further explained that strategies are aligned with places. For example, classrooms are often understood as places in which there are appropriate ways to teach, learn, and behave. There are often fixed ideas about what happens in classrooms and who belongs in them. 
Space, on the other hand, "is a practiced place" (de Certeau, 1984, p. 117) that lacks the stability of the "proper." Space is more fluid and is susceptible to tactics, the maneuvers of the less powerful used to "make do" within a space that does not belong to them (de Certeau, 1984). Similarly, Lefebvre (1991) conceived of "lived space" as the way in which people use space in relation to their understandings of its purposes and boundaries. As Sheehy and Leander (2004) explained, "Social practice is always dominated by particular representations that seem 'natural,' but people's bodily experiences of social life differ, and contradictions to dominant, conceived space enable the impossibility of the production of a fixed, stable space" (p. 4). Other literacy researchers have put forth similar theories about the flexibility of space and how it is created through negotiation in classrooms (Dyson, 2003; Handsfield et al., 2010; Hirst, 2004; Leander, 2004; Leander \& Rowe, 2006). For example, Hirst (2004) stated, There is conflict over the privileging of cultural resources. Who has the resources to claim authority over the public space of the classroom or restrict other's access to this space? This classroom is a site of multilayered spaces, each with its own border, some more flexible than others. The counterspaces are not harmonious or entirely overlapping; their emergence reveals the inherently heterotopic nature of any classroom. The borders between these spaces are constantly being negotiated and monitored. (p. 60-61).

Within this spatial framework, classrooms can be imagined as transformative spaces in which literacy coaches can negotiate their roles in tactical ways in order to leverage positive change. 
A spatial view of literacy coaching also emphasizes how coaches see themselves and others in relation to the spaces in which they work. As Sheehy and Leander (2004) explained, "social space enables performance of particular identities" (p. 7). Moje (2004) argued that "identity can be considered an enactment of self made within particular spaces (geographic, social, electronic, mental, and cultural) at particular points in time" (p. 16). Within a dynamic view of space as socially constructed and fluid, space is more than just a situational context or backdrop for identity construction. Identity and space shape one another (Moje, 2004). Thus, literacy coaches may be constrained by the spaces in which they work, but they also have the power to transform those spaces into something new. Lived space is "space that imagination seeks to change" (Sheehy \& Leander, 2004, p. 4).

\section{Significance}

Within this theoretical framework, literacy coaching occurs within a complex nexus of identity, power, and positioning. From this view, special attention to the in-themoment interactions in which coaches and teachers co-construct their understandings of themselves, each other, and the professional learning community is warranted. In this study, therefore, I will focus on exploring the daily interactions between coaches and teachers in order to glimpse how they navigate the complexities of collaborative professional learning through literacy coaching.

An understanding of how literacy coaches and teachers discursively negotiate issues of identity, power, and positioning has several potential benefits for the field of literacy research and the practice of coaches and teachers. First, such an understanding may shed light on how professional learning spaces can be reimagined and reshaped in 
ways which open up opportunities for positive change in teachers' professional development and students' literacy learning. Second, an open acknowledgement of positioning, power, and identity in the work of literacy coaching may provide spaces for coaches and teachers to grapple with the complexities of collaborative professional learning. Lastly, a recognition of emotions offers a more expansive view of literacy coaching, which highlights the interpersonal nature of building relationships with teachers, and may offer clues to how coaches and teachers negotiate tensions within and across moment-by-moment, day-to-day interactions.

\section{Overview of Chapters}

In chapter two, I begin by providing background information about the historical development of literacy coaching and different models of coaching. Secondly, I review the literature through a lens of identity, power, and positioning with a focus on how coaches and teachers are positioned within the research.

In chapter three, I outline the research design and methodological frame that I used to conduct the study. I begin by summarizing a research paradigm that explains the epistemological and ontological stance with which I approached the project. I also explain the microethnographic approach that served as my primary methodology for answering the research questions. Finally, I provide a detailed discussion of my strategies for data generation and analysis and attend to issues of positionality, subjectivity, reflexivity, and ethics.

In chapter four, I share contextual information about the literacy coaches' and teachers' work. Specifically, I share the participants' definitions, understandings, and expectations of literacy coaching and professional learning. Next, I explain the dominant 
Discourses of best practices, development, credibility, and collaboration that circulated within the schools and district.

In chapters five and six, I present my microanalyses of five video-recorded interactions between coaches and teachers. In chapter five, I give a detailed description of the context and work of a middle school literacy coach, Sarah, and analyze her individual and small group interactions with five teachers. In chapter six, I introduce a primary school literacy coach, Grace, and analyze her individual interactions with two teachers.

Chapter seven includes a summary and discussion of the findings presented in chapters four through six. My discussion highlights how dominant Discourses circulated through the interactions and interviews, thus limiting the coaching interactions. I also highlight how the coaches and teachers simultaneously aligned themselves with and resisted these dominant Discourses.

In the final chapter, I briefly review and summarize the findings in relation to my research questions as well as discuss the study's significance. Then, I discuss the limitations of the study and implications for research and for coaching practice. 


\section{CHAPTER II}

\section{REVIEW OF LITERATURE}

Literacy coaching has developed quickly over the last decade as many districts across the nation have hired literacy coaches in an attempt to keep up with the increasing demands of standardization and high stakes testing as fueled by the No Child Left Behind Act of 2001(Casey, 2006; Toll, 2005; Vogt \& Shearer, 2007). Funding for hiring literacy coaches became available through initiatives such as Reading First, and many states included literacy coaching as part of their comprehensive reform efforts aimed at increasing student achievement in reading and writing in underperforming schools (International Reading Association, 2004). Definitions of literacy coaching vary greatly across states, districts, and from school to school, which often causes confusion among coaches, teachers, and administrators about the purposes of coaching (Bean, Swan, \& Knaub, 2003; Dole, 2004; Deussen et al., 2007; Otaiba et al., 2008; Vanderburg \& Stephens, 2010; Walpole \& Blamey, 2008). Such ambiguities concerning the purposes of literacy coaching produce spaces of negotiation in which coaches, teachers, and administrators must come together to determine what literacy coaching means and how it will be enacted in their schools and classrooms.

In this chapter, I present a review of the research literature on literacy coaching. I begin by outlining its philosophical foundations, including a brief history of the term coaching and a discussion of prominent models. I then present a review of the literature 
from the perspective of positioning theory as outlined in the previous chapter. I explore how literacy coaches and teachers have been positioned in practice, by the research, and how researchers have or have not attended to issues of positioning, power, and identity. Finally, I critique the existing research and point towards possibilities for further research, which I take up in this study.

\section{Philosophical Foundations of Literacy Coaching}

\section{Literacy Coaching Models}

The many different conceptions of literacy coaching are based on broader models of coaching dating back to the early 1980s (Showers \& Joyce, 1996). The most common and influential models include peer coaching (Joyce \& Showers, 1980) and cognitive coaching (Costa \& Garmston, 2002). Other models include instructional coaching (Knight, 1994), content-focused coaching (West \& Staub, 2003), and technical coaching (Joyce \& Showers, 1980). Models that are specific to literacy coaching include informal (Toll, 2005) and formal (Walpole \& McKenna, 2004; Sturtevant, 2006) coaching. These models have distinct features but also overlap and have fluid boundaries with some models fitting into more than one category. For example, Joyce and Showers (2002) refer to their model as peer coaching, but it can also be considered a technical approach (Toll, 2005). Furthermore, each model entertains different assumptions about how students and teachers learn and what the purposes of coaching are. As Toll (2007) argued, "A range of epistemological stances could be reflected by various understandings of coaching” (p. 50). Therefore, it is important to review the different models of coaching, how literacy coaching is understood in the research literature, and how it is implemented in schools. 
See Table 2.1 for a summary of several prominent models based on a synthesis of the research on literacy coaching.

\begin{tabular}{|c|c|c|}
\hline $\begin{array}{l}\text { Table } 2.1 \\
\text { Coaching Mc }\end{array}$ & dels & \\
\hline $\begin{array}{l}\text { Coaching } \\
\text { Model }\end{array}$ & $\begin{array}{l}\text { Examples from } \\
\text { Literature }\end{array}$ & Description \\
\hline Peer & \begin{tabular}{|l|} 
Joyce \& \\
Showers, \\
1980/1996/2002 \\
\end{tabular} & $\begin{array}{l}\text { Teachers coach each other through practice } \\
\text { and observations of new teaching strategies. }\end{array}$ \\
\hline Technical & \begin{tabular}{|l|} 
Joyce \& \\
Showers, \\
1980/1996/2002
\end{tabular} & $\begin{array}{l}\text { Teachers learn new teaching strategies } \\
\text { drawn from "the knowledge base" of best } \\
\text { practices as presented by outside experts in } \\
\text { a workshop environment. } \\
\text { - Coaching allows for the transfer of new } \\
\text { strategies from the workshop to the } \\
\text { classroom. }\end{array}$ \\
\hline Cognitive & $\begin{array}{l}\text { Costa \& } \\
\text { Garmston, } 1994\end{array}$ & $\begin{array}{l}\text { - Coaches support teachers to improve } \\
\text { existing instructional practices through } \\
\text { reflection and collaboration. } \\
\text { - Includes pre/post conferences around } \\
\text { classroom observations. }\end{array}$ \\
\hline $\begin{array}{l}\text { Content- } \\
\text { focused/ } \\
\text { Instructional }\end{array}$ & $\begin{array}{l}\text { West \& Staub, } \\
\text { 2003/ } \\
\text { Knight,1994 }\end{array}$ & $\begin{array}{l}\text { - Coaches support teachers to improve } \\
\text { content-area instruction. } \\
\text { More common at middle school and high } \\
\text { school levels. }\end{array}$ \\
\hline $\begin{array}{l}\text { Informal } \\
\text { literacy } \\
\text { coaching, } \\
\text { Mentoring }\end{array}$ & Toll, 2005/2006 & $\begin{array}{l}\text { - Coaches wait for invitations to work with } \\
\text { teachers. } \\
\text { - Coaching is teacher directed. }\end{array}$ \\
\hline $\begin{array}{l}\text { Formal } \\
\text { literacy } \\
\text { coaching }\end{array}$ & $\begin{array}{l}\text { Walpole \& } \\
\text { McKenna, 2004; } \\
\text { Sturtevant, 2006 }\end{array}$ & $\begin{array}{l}\text { - Coaches support school-wide reform } \\
\text { initiatives. } \\
\text { - Coaches provide feedback to teachers. } \\
\text { - Includes pre/post conferences around } \\
\text { classroom observations. }\end{array}$ \\
\hline
\end{tabular}

Peer coaching. The term coaching was first used for embedded professional development in education by Joyce and Showers (1980). Their model of peer coaching 
grew out of the research on clinical supervision (Cogan, 1973; Goldhammer, 1969), which advocated collaboration between teachers and supervisors to improve classroom instruction through reflection and conversation about observed teaching behaviors. Like clinical supervision, Joyce and Showers' model of peer coaching involves a preconference with the teacher, observation of a classroom lesson, and a post conference with feedback. Their model, however, differs from clinical supervision in several key ways. Most importantly, coaching occurs between two equal peers rather than from a supervisor. They also include professional development presentations of specific teaching strategies or skills, modeling of these skills, and opportunities to practice in both simulated and authentic classroom settings. More recently, Showers and Joyce (1996) amended their peer coaching model to eliminate feedback. They argued that "when teachers try to give one another feedback, collaborative activity tends to disintegrate" because they find themselves "slipping into supervisory, evaluative comments" (p. 15).

Technical coaching. Joyce and Showers' (1980/2002) model can also be classified as a form of technical coaching, which is based in a scientific-rational understanding of teaching and of professional learning as the transmission of specific instructional techniques (Rainville, 2007; Toll, 2007). Within this model, coaches and teachers are expected to "get it right" (Toll, 2007, p. 8) in terms of implementing instructional strategies and skills into the classroom and maintaining fidelity to an instructional model, program, or reform initiative as determined and presented by outside consultants. Joyce and Showers' (2002) technical stance is evident in several components of their peer coaching model. For example, they argued that there is a general knowledge base of best instructional models such as information processing, scientific inquiry, and 
cooperative learning that should be presented to teachers by an expert in a workshop environment. The teachers should then have opportunities to practice, model, and observe each other in both simulated and authentic classroom situations in order to support the transfer of the presented strategies into their daily teaching practice.

This technical view is common among current conceptualizations and implementations of literacy coaching (Toll, 2007). For instance, much of the work on literacy coaching advocates for a coaching cycle that consists of pre and post conferences around classroom observations and may also include demonstration lessons by the coach (Buell et al., 2010; Casey, 2006; Fountain \& Wood, 2009; Hsieh, Hemmeter, McCollum, \& Otrosky, 2009; Teemant, Wink, \& Tyra, 2010). Furthermore, the purpose of coaching is often to promote fidelity to a particular program or reform initiative (McKenna \& Walpole, 2008). For example, many researchers have documented the work of literacy coaches who work in districts implementing the Early Reading First and Reading First reform initiatives as mandated for low-performing schools under No Child Left Behind (Buell et al., 2010; Coburn \& Woulfin, 2012; Mclean, Mallozi, Hu, \& Dailey, 2010; NCLB, 2002; Powell, Steed, \& Diamond, 2009; Scott, Cortina, \& Carlisle, 2012; Walpole, McKenna, Uribe-Zarain, \& Lamitina, 2010; Walpole, McKenna, \& Morrill, 2011). Other research has focused on literacy coaches who support the implementation of specific instructional programs such as Open Court, Success for All, Reading Mastery, (MacGillivray et al., 2004) or Direct Instruction (Kretlow, Wood, \& Cooke, 2011).

Hargreaves and Dawe (1990) criticized technical approaches to coaching on several grounds. First, they argued that technical coaching and other professional development strategies, which focus on training for specific instructional behaviors, limit 
professional discussions to techniques and procedures and preclude questions of educational purposes and vision. Secondly, technical coaching does not acknowledge the complexities and the deeply moral nature of teaching, and it ignores ecological, contextual, personal and biographical factors. Hargreaves and Dawe envisioned teaching as a moral endeavor because it is steeped in values about "what and how things are taught" (p. 235). Thus, they argued that "what it is to be coached in teaching cannot be reduced solely to matters of technical skill and competence, but involves choices of a personal, moral, and socio-political nature" (p. 236). Lastly, they argued that mandatory partnerships can result in a "contrived congeniality" in which "under the aegis of professional collaboration and personal development, lurks an administrative apparatus of surveillance and control" (p. 239).

Despite these criticisms, there are several strengths to Joyce and Showers' (1980) approach to coaching. For instance, the emphasis on teacher reflection and collaborative professional learning has affected how professional development is delivered in schools by encouraging a move beyond one-shot workshop approaches and a connection between educational theory and practice. Moreover, their model of teachers coaching teachers encourages an equal partnership, which can enhance collegiality and collaboration. They expressed concern over the spreading practice of appointing one teacher to the position of coach and argued that positioning the coach as the expert moves the model away from peer collaboration and towards peer supervision (Joyce \& Showers, 2002).

Cognitive coaching. Most models of coaching, however, are built around the idea of appointing an expert other as the coach. One such model, cognitive coaching (Costa \& Garmston, 2002), focuses on professional learning through reflection and aims to change 
teachers' inner thoughts and belief systems in ways that will improve existing instructional practice. Like Joyce and Showers' model, cognitive coaching includes a preconference, observation of a lesson, and post conference. It differs in that it focuses more on improving existing instructional practice rather than on implementing new teaching strategies. Cognitive coaching also places more emphasis on establishing trusting relationships and mutual learning between coaches and teachers (Vogt \& Shearer, 2007).

Informal literacy coaching. Many current conceptualizations of literacy coaching have a similar emphasis on collaborative professional learning and trust (Bean et al., 2003; Buell et al., 2010; Dowell, 2012; Ferguson, 2011; Gardiner, 2012; Gibson, 2006; Otaiba et al., 2008; Peterson et al., 2009; Rainville \& Jones, 2009; WalkerDalhouse, Risko, Lathrop, \& Porter, 2010). For instance, informal literacy coaching models focus on supporting teachers outside of the classroom through activities such as goal-setting or planning conferences, providing resources and materials, and participating in study groups (Vogt \& Shearer, 2007). Within informal models, the literacy coach is a supportive colleague who "helps teachers to recognize what they know and can do, assists teachers as they strengthen their ability to make more effective use of what they know and do, and supports teachers as they know more and do more" (Toll, 2005, p. 4).

Such informal coaching grows out of the tradition of mentoring in which a more experienced educator assumes a collaborative role and nonjudgmental stance (L'Allier, Elish-Piper, \& Bean, 2010; Vogt \& Shearer, 2007). Such mentoring relationships have the potential to offer valuable emotional and professional support to teachers, especially beginning teachers. However, as Vogt \& Shearer (2007) have argued, "anytime the word 
mentor is used, no matter how egalitarian the intent or thorough the reassurance that the relationship is reciprocal, it is inherently unequal" (p. 199).

Formal literacy coaching. Other models of literacy coaching are more formal and often include elements of technical coaching such as observation and feedback in classrooms (Biancarosa, Byrk, \& Dexter, 2010; Dole, 2004; Ippolito, 2010; Mraz et al., 2008; Walpole \& Blamey, 2008; Walpole \& McKenna, 2004). Additionally, coaches working with a formal model are frequently responsible for school-wide initiatives such as providing whole group professional development workshops and coordinating schoolwide literacy improvement plans and assessments (Kissel, Mraz, Algozzine, \& Stover, 2011; Neufeld \& Roper, 2003; Otaiba et al., 2008; Scott et al., 2012; Stephens et al., 2011). Proponents of formal literacy coaching argue that coaches are in a unique position to connect individual teacher learning with school, district, and state literacy initiatives and to bridge the gap between professional development workshops and classroom practices (Bean, 2004; Blachowicz et al., 2010; Sturtevant, 2006; McKenna \& Walpole, 2008). Caution is warranted, however, as "despite valiant efforts to assume a nonjudgmental stance, those who engage in [formal] coaching encounter increased anxiety on the part of some teachers" (Vogt \& Shearer, 2007) and may experience resistance to their reform efforts. McKenna and Walpole (2008) describe their formal coaching model as "hard coaching," which is grounded in the idea that there are best practices based on empirical research and is intrusive in that it requires literacy coaches to work in and out of the classroom to ensure their implementation. They warn that as literacy coaches work towards this goal, they "may encounter road blocks and resistance" (p. 14). 


\section{Literacy Coaching and Vygotsky}

Although there are several theoretical perspectives that inform different models of literacy coaching, a common thread is an emphasis on Vygotskian sociocultural theories of development (Vygotsky, 1962). Specifically, much of literacy coaching research and practice draws heavily on Vygotsky's notions of learning as a process of social interaction mediated through language and the zone of proximal development, or ZPD (Biancarosa et al., 2010; Blackstone, 2007; Casey, 2006; Collet 2012; McLean et al., 2012; Stover, Kissel, Haag, \& Shoniker, 2011). Teemant et al. (2010) explained the ZPD as embodying "the difference between what a student can do on his/her own and what can be done with assistance from a more knowledgeable other" (p. 4). Working within the students' ZPD, teachers provide supports as the students attempt tasks that are slightly more difficult than what they would be able to do on their own. This kind of scaffolding (Wood, Bruner, \& Ross, 1976) is closely related to the idea that literacy coaches can support teachers and shift their thinking as they work alongside them in the classroom (Casey, 2006). In a similar vein, it is often argued that coaches should assess teacher knowledge in order to meet teachers "where they are as instructors" (Stover et al., 2010). As noted by several authors (Chaiklin, 2003; Engeström, 2005; Gutièrrez, Larson, Enciso, \& Ryan, 2007; Smorgorinsky, 2011), literacy researchers and educators have taken up Vygotsky's theories in a variety of ways that do not always closely align with his original intents. Therefore, I want to acknowledge that the following critiques do not necessarily pertain to Vygotsky's original writings but, rather, to dominant ideas related to his work. His sociocultural theory of development has been incredibly influential in the field of education (Smagorinsky, 2011), but researchers from a variety of theoretical 
perspectives have begun to encourage a more critical reading of his work and the expansion of his theories to include issues of power, positioning, and identity (Harrè \& Moghaddam, 2003; Lewis, Enciso, \& Moje, 2007; Matusov, 1998; Rogoff, 1990; Roth \& Radford, 2010). For example, Lewis et al. (2007) argued, In sociocultural theory, the focus is on how individuals shape identities as they come to belong to communities of practice rather than on how they shape identities in relation to the conflicting discourses that are always present in such communities. Yet, we know, from our own collective research, moments of conflict and disjuncture are often the spaces in which learning occurs. (p. 5) Within a neutral frame, development can be easily misrepresented as universal, normal, and valueless. As Matusov, DePalma, and Dyre (2007) stated, "Developmental theories remain decidedly modernist in their assumption of an objective progression through preexisting stages that are 'out there,' essentialized into being without acknowledging the influence of particular developers and observers in particular spaces and times" (p. 404). For literacy coaching, this means that it is important to consider the contextual factors that comprise local understandings about who coaches are and what they do and how professional learning is defined and achieved.

Positioning theorists have also identified problematic aspects of the ZPD (Harré \& Moghaddam, 2003; McVee, 2011). Namely, within any community, there are diverse understandings of who has the right or duty to act as the supporting expert. As such, the position of expert is locally and discursively co-constructed and is variant and changing. For example, people with mental disorders are often positioned as deficient and "simple minded" in contemporary Western society, but in other times and places their utterances 
were given the high status of prophecies (Harré \& Moghaddam; 2003). Applied to literacy coaching, we might imagine that coaches and teachers are recognized as more or less expert depending on the local norms of the schools and districts in which they work.

Harrè and Moghaddam (2003) pointed to positioning as a missing element of Vygotskian theory. They argued,

In any unfolding social episode, who could perform which actions and so contribute this or that act to the episode structure as a whole depended on subtly varying presuppositions as to right of access to the local repertoire of acceptable conduct and the presuppositions as to the distribution of duties to perform the necessary actions. The concept of 'position' has been introduced to fill this gap. (p. 4)

In other words, positioning theory emphasizes the power structures surrounding the discursive acts that participants in any social event use to construct understandings of self and others (McVee, 2011). When applied to literacy coaching, one might ask who is positioned as the expert and as the novice, what counts as relevant knowledge and context, and how social positionings affect relationships and outcomes.

\section{The Literacy Coach as Expert}

Many researchers have claimed that literacy coaches should be experts (Blachowicz et al., 2005; Deussen et al., 2007; Dole, 2004; Dole, Liang, Watkins, \& Wiggins, 2006; Gibson, 2006; Kissel et al., 2011; Mangin \& Stoelinga, 2011; Mraz, Kissel, Algozzine, Babb, \& Foxworth, 2011; Teemant et al., 2010; Walpole et al., 2011). The International Reading Association (2004) has argued that "Reading coaching is a powerful intervention with great potential; however, that potential will be unfulfilled if 
reading coaches do not have sufficient depth of knowledge and range of skills to perform adequately in the coaching role" (p. 4). They list necessary qualifications for reading coaches, including:

1. Successful experience teaching at the grade level at which they are providing coaching support.

2. In depth knowledge of reading processes and development which may be gained through reading specialist certification, ongoing professional development, or year-long district training for new coaches.

3. Experience with professional development and reflective teaching.

4. Excellent presentation skills and experience speaking at conferences and other professional venues.

5. Experience with or preparation for observing, modeling, and providing feedback and developing trusting relationships with teachers.

Other research on literacy coaching has also asserted the importance of literacy coaches' qualifications and expertise. For example, Dole (2004) argued that literacy coaches must have a greater level of expertise than the teachers that they work with so that they can "move teachers on to more advanced stages of reading instruction" (p. 469).

Some researchers have suggested that literacy coaches should take measures to ensure that teachers view them as experts. Gibson (2006) suggested that it is important for coaches to maintain an "expert stance" during coaching conversations with teachers. Similarly, Mangin and Stoelinga (2011) asserted that literacy coaches should be careful not to compromise their standing as an expert in their attempt to build trusting 
relationships with teachers but should redefine peer relationships to include critique and difficult conversations about instruction. Blachowicz et al. (2005) urged literacy coaches to "establish your credentials" so that teachers will view them as capable and trustworthy.

Despite these claims, there is little evidence that a literacy coach's qualifications (i.e. years of experience, advanced degrees, etc.) positively affect literacy coaching outcomes such as student achievement, teacher satisfaction, and implementation of instructional practices. There are mixed results about the importance of coaching expertise (Bean et al., 2010; Elish-Piper \& L'Allier, 2010; Marsh et al., 2008; Marsh, McCombs, \& Martorell, 2010; Scott et al., 2012). For instance, in a quantitative study of five coaches working with 421 Kindergarten teachers and 13 first grade teachers, Elish Piper and L'Allier (2010) compared the time coaches spent with teachers to student achievement gains. They found that the time spent observing teachers in the classroom predicted student achievement gains as measured by the Illinois Snapshots of Early Literacy Assessment. They noted that the teachers with the lowest gains in student achievement were supported by a reading coach without specific qualifications in reading instruction, and the classrooms with the highest gains in student achievement were supported by a reading coach who had a reading endorsement and was obtaining a masters degree. This result seems to suggest that coaching qualifications are a positive factor in increasing student achievement.

However, other studies were less favorable in their conclusions about the importance of coaching qualifications. In a mixed-methods study of literacy coaching in 113 middle schools across eight districts, Marsh et al. (2008) found that there was no association between the reading credentials of coaches and higher student achievement in 
reading as measured by the Florida Comprehensive Assessment Test. In a similar study, Marsh, McCombs, and Martorell (2012) found significant associations between indicators of coaching experience, knowledge, and skills and teachers' and administrators' perceptions of improvement in student learning but only a small association with improved student achievement scores. They concluded that "although possessing strong reading knowledge and instructional expertise may be important for coaching, it may not be sufficient" (p. 1). Scott et al. (2012) found that qualifications such as holding a masters degree or reading specialist certificate did not correlate with teachers' satisfaction with their literacy coach. Given the paucity of evidence that expertise in coaching, as defined by special qualifications, knowledge, or skills, results in improvements in teacher or student learning, it may be time for researchers to rethink positioning literacy coaches as the expert other.

Although there is little doubt that literacy coaches need to be competent and committed educational professionals, casting them as more expert than the teachers with whom they work can be problematic for a variety of reasons. Several researchers have begun to investigate the power relationships associated with a "coach as expert" view of professional development (Blachowicz et al., 2010; Crafton \& Kaiser, 2011; Hibbert, Heydon, \& Rich, 2008; Lynch \& Ferguson, 2010). In one notable example, Hibbert et al. (2008) conducted a case study of a lead teacher initiative in Ontario, Canada sponsored by the Education Ministry. The goal of the initiative was to develop expert teachers through a hierarchical top-down model of professional development. Those experts, identified as "lead teachers," were then responsible for supporting their fellow teachers in implementing best practices as defined by the ministry's Expert Panel Reports. Hibbert et 
al. found that "persons at all levels of the hierarchy...saw those beneath them as lacking and from lead teachers up, those above them as more expert than themselves (p. 313). From a post-colonial perspective, they argued that this hierarchical transmission model positioned teachers as deficient and restricted their practice. They advocated instead for professional development that promotes teacher knowledge production and offers "a wider array of subject positionings" (p. 314).

Other researchers have made similar arguments. For instance, Bean et al. (2010) argued that coaches must be knowledgeable experts, but literacy coaches should recognize the special expertise of teachers by focusing on collaborative problem solving around students' needs. Jewett and MacPhee (2012) explained how teachers learning to be peer coaches resisted practices such as observation and feedback because they wanted to position themselves as co-learners rather than as experts. Similarly, Crafton and Kaiser (2011) argued that literacy coaches must be careful not to position teachers as less expert through their language choices. They conducted discourse analysis of professional study groups and illustrated how literacy coaches may position teachers as less knowledgeable by leading discussions with traditional Initiate-Respond-Evaluate (IRE) discourse patterns. They also offered an alternative discourse pattern in which turn taking was distributed amongst all participants of the study group and no one person took on the lead expert role. Crafton and Kaiser concluded that literacy coaches should construct discourse that supports equal participation in a community of practice as outlined by Lave and Wenger (1991). They pointed out the role of language in building more equal relationships with teachers stating, "In working with teachers, it matters if an outside expert is called a 'coach' rather than a 'colleague' or 'learning partner'” (p. 108). 


\section{Positioning Teachers through Literacy Coaching}

The research on literacy coaching often negatively positions teachers, presenting them as novices, as deficient, or resistant to change. Although very few researchers have explicitly studied how teachers are positioned by literacy coaching (for exceptions see Crafton \& Kaiser, 2011; Hibbert et al., 2008), a review of the literature reveals certain common assumptions about teachers. For instance, a large portion of the body of research refers to literacy coaching as an intervention (Dowell, 2012; Hsieh et al., 2009; Kennedy \& Shiel, 2010; Kretlow et al., 2011; Lockwood, McCombs, \& Marsh, 2010; Matsumura et al., 2010; Neuman \& Cunningham, 2009; Powell et al., 2009). This view of literacy coaching operates within a behaviorist perspective of learning and a medical model of dosage and treatment (Neuman \& Wright, 2010).

Teachers are often positioned as non-expert technicians within a policy framework of best practices and evidence-based reading instruction (De Alba-Johnson, et al., 2004; Hsieh et al., 2009; Kretlow et al., 2011; Poglinco et al., 2003; Powell et al., 2009; Stephens et al., 2011; Sturevant \& Linek, 2007). A focus on implementation positions teachers in relation to the goals of a body of experts and, as such, teachers must achieve these goals in order to be seen as competent professionals (Beijaard, Meijer, \& Verloop, 2004). Within this perspective, literacy coaches are responsible for ensuring that teachers follow the instructional practices of a particular program required by the district. As Hibbert et al. (2008) noted, the focus of literacy coaching and other professional development measures becomes centered on "teachers needing to do $\mathrm{x}$ and $\mathrm{y}$ to aid student achievement" (p. 305). Other factors contributing to student learning, such as the 
structure of the school system, available resources, and broader societal factors, are not given appropriate attention (Hibbert et al., 2008).

Within this methods paradigm, teachers are positioned as in need of training. As such, the goal of professional development is to transmit knowledge about best practices to teachers so that they can implement programs with fidelity. This model of professional development ignores teachers' existing expertise (Kretlow et al., 2011) and positions teachers as blank slates (Hibbert et al. 2008). As Hoffman and Pearson (2000) argued, training is akin to indoctrination, which situates knowledge with the teacher, or in this case literacy coach, rather than with the learner. They claimed that training is insufficient for preparing teachers for the complex nature of teaching and stated,

It may get teachers through some of the basic routines and procedures they need for classroom survival, but it will not help teachers develop the personal and professional commitment to lifelong learning required by those teachers who want to confront the complexities and contradictions of teaching. (p. 36)

Teachers are further positioned as resistant to change. As Hibbert et al. (2008) argued, teachers often must "either align more closely with the dominant Discourse or suffer the consequences" of "being viewed as resistant to change or unwilling or unable to get on board" (p. 313). Several researchers have highlighted teacher resistance as an obstacle to literacy coaching (Dole \& Donaldson, 2006; Ferguson, 2011; Lynch \& Ferguson, 2010; Morgan et al., 2003; Toll, 2005). In one such study, Lynch and Ferguson (2010) interviewed 13 literacy coaches and used constant comparative analysis to identify teacher resistance as one of the primary barriers to literacy coaching success. They claimed that "perceptions of power inequality may have supported the resistance among 
teachers," which is consistent with "Foucault's assumption that resistance will occur anywhere power exists" (p. 216). Ferguson (2011) used a Foucaldian perspective of power to analyze the social relationships between coaches, teachers, and administrators in Ontario, Canada and identified teacher resistance as a salient power dynamic among them. She noted that teacher resistance was also spoken of as a barrier from the past that had been overcome but that some teachers still resisted reform efforts by participating in literacy coaching interactions less frequently.

Positioning teachers as resistant casts them in a negative light rather than acknowledging the ways they may be tactically negotiating against practices that they view as detrimental for their students (Toll, 2007). It may be beneficial to position teachers instead as advocates for their students and as professionals who can effectively judge the appropriateness of instructional materials and practices and the needs of their students. As Hargreaves and Dawe (1990) argued, teacher resistance is often identified as a personal weakness among individual teachers but may be rooted in warranted objections to the pedagogical paradigm being pushed by the literacy program or initiative.

Furthermore, when teachers are viewed as resistant, it becomes part of the literacy coach's job to overcome their resistance by pressuring them to accept school reform agendas and to implement particular practices in their classrooms. Several researchers have argued that effective literacy coaches should apply pressure to teachers in order to improve teacher practices (Coburn \& Woulfin, 2012; Ippolito, 2010; Mangin \& Stoelinga, 2011). For instance, Mangin and Stoelinga (2011) argued that literacy coaches must incorporate "hard feedback" into their peer relationships with teachers or they will 
not be able to make critical changes to instructional practices in classrooms. Similarly, Ippolito (2010) stated, "specific circumstances foster a balance of responsive and directive moves without damaging coach-teacher relationships" (p. 184).

In contrast, others have argued that literacy coaches should not provide feedback in order to avoid presenting themselves as evaluators or as more expert than teachers (Ferguson, 2011; Showers \& Joyce, 1996; Lynch \& Ferguson, 2010; Toll, 2005). They argue that adding evaluative feedback to coaching conversations impedes the development of trusting, collaborative relationships between literacy coaches and teachers. This line of scholarship recognizes the challenges that arise when teachers are positioned as the less expert other, and it proposes an alternative positioning of teachers as knowledge producers and expert professionals.

\section{Literacy Coaching and Identity}

Literacy coaches are also positioned by different models of coaching and by contextual factors particular to their schools and districts. These positions are intricately linked to their social and professional identities. As Davies and Harré (1990) argued, "Who one is, that is, what sort of person one is, is always an open question with a shifting answer depending upon the positions made available within one's own and others' discursive practices" (p. 35). Several researchers have noted how coaches' identities shift as they position and reposition themselves across school contexts. For instance, Rainville and Jones (2008) conducted one of the first studies that focused on issues of identity, power, and positioning in literacy coaching. They explored how one coach, Kate, enacted "situated identities" (Gee, 1999) as she moved from classroom to classroom to work with different teachers. Through ongoing, cyclical analysis of participant observations, video- 
taped observations, interviews, and artifacts, they investigated how and why literacy coaches negotiate varied identities across school contexts. They argued that "the coach and teacher use language (verbal and nonverbal) to wield power and position themselves in various ways: as friend, colleague, authority, expert, learner, and so forth" (p. 441).

Similarly, Mangin and Dunsmore (2013) used positioning theory to examine how one literacy coach, Diane, managed the conflicting perspectives of a regional literacy coach preparation program and her school and district administration. The district's storyline considered coaching to be a tool for changing teachers' instructional behaviors to align with mandated literacy initiatives such as the Four-Blocks Literacy model and Lucy Calkin's Reading and Writing Strategies. The preparation program had a different storyline in which literacy coaches worked as facilitators and only with teachers who specifically requested a one-on-one conversation. Within these conflicting storylines, Diane struggled with decisions about when and how to work with teachers and with negotiating "under what conditions she could utilize her expertise in literacy and teaching to facilitate instructional reform" (p. 236). The authors argued for the need to acknowledge the contextual nature of coaching and for stakeholders to come to a consensus about the "purposes, processes, and norms associated with a particular coaching model" (p. 246).

Stevens and Hinchman (2011) conducted a case study using critical discourse analysis to explore how one teacher enacted her identities as she completed a graduate literacy specialist program. They found that the teacher drew on her professional identity as an experienced teacher as well as personal identities related to her experiences with motherhood and religion. They argued that the dominant Discourses of the school and the 
wider society may be more powerful than any professional development initiative. Therefore, they concluded that a deeper understanding of the process of identity construction is needed in order to guide educators to "weave experiences into identities that acknowledge social forces in more complex, empathetic, and instructionally effective ways" (p. 26).

Teachers may experience shifting identities as a result of literacy coaching interactions as well. For example, Toll (2005) drew on Holland et al.'s (1998) theory of figured worlds to explain how teacher identities are influenced by teacher-coach interactions. She argued that teachers respond to common stories, or figured worlds, about who they are supposed to be as teachers including the obedient teacher, the good teacher, the teacher who solves problems, and the teacher who has agency. She claimed that "each figured world of teaching that results from literacy coaching constructs at least two ways for teachers' power to be visible: either by living up to the identity... or by working against the identity constructed in the figured world" (p. 62).

Crafton and Kaiser (2011) briefly noted issues of identity in their analysis of discourse practices used by coaches and teachers within a community of practice. They pointed out the dialogic nature of identity construction during professional study groups led by literacy coaches. They argued that identities are relational and are partially constructed and limited by the power relationships within communities of practice. In their study, teachers were more likely to enact identities as inquiring professionals if they were participating in a study group with less hierarchical organization. They concluded that the language literacy coaches use plays a role in determining "how situated identities are shaped" (p. 114). 


\section{Limitations of Existing Research}

In sum, the bulk of the research on literacy coaching has focused on clarifying roles and expectations, identifying effective models, and prescribing coaching behaviors (Ippolito, 2010; Mraz et al., 2008; Peterson et al., 2009; Steckel, 2009; Walpole \& Blamey, 2008). While this research may be helpful for literacy coaches, there is generally an insufficient focus on the complexities of coaching interactions in terms of power, positioning and identity. As Vanderburg and Stephens (2010) argued, research needs to move beyond what coaches "ought to do" (p. 158) in order to closely examine their lived experiences and to explore how they negotiate understandings about literacy and professional learning with teachers and other stakeholders. In this study, I examine such complexities by drawing from a wider research base that includes theories about identity, power, positioning, space, and emotions.

\section{Considering Literacy Coaching as Spatialized Practice}

Shifting identities and multiple positions do not occur in isolation but are shaped by and reflected in the institutional spaces in which literacy coaches and teachers interact (Hunt \& Handsfield, 2013). Nevertheless, much of the research on literacy coaching treats space as merely a backdrop for professional learning (Asaf, 2005; McKinney \& Giorgis, 2009; Scott et al., 2012; Smith, 2007). A few studies have acknowledged the importance of space in the coproduction of literacy coaching Discourses (Crafton \& Kaiser, 2011; McLean et al., 2010; Stevens \& Hinchman, 2011). Such scholars have pointed to Bakhtin's (1981) dialogic imagination in which literacy coaches and teachers discursively negotiate spaces in order to "merge old and new identities" (Stevens \& Hinchman, 2011), create new meanings of professional learning (Crafton \& Kaiser, 
2011), and reposition themselves in relation to authoritative Discourses (McLean et al., 2010).

An acknowledgement that "space matters" (Soja, 2004) is important for literacy coaching research because it opens up transformative possibilities (Hunt \& Handsfield, 2013). As Soja (2004) argued, when literacy scholars and educators attend to the coproduction of space,

The traditional confines of the classroom explode with new possibilities of interpretation, as this preeminent learning space is opened up to a wider, real and imagined world of ethnic, gender, and class consciousness, conflicting identity formations, creative cultural hybridities, new political positionings, an extensive microcosm of everyday life at multiple geographical scales, from the local to the global. (p. x)

Within this spatial perspective, literacy coaches, teachers, and administrators have opportunities to renegotiate the meanings of professional learning, collaboration, and the purposes of literacy coaching.

\section{Considering Emotions}

The research is peppered with mentions of literacy coaches' emotions in relation to the unique challenges of literacy coaching, but there are few substantive discussions of how emotions are enacted within literacy coaching interactions. Rather, researchers mention literacy coaches' specific emotions, such as frustration with unclear expectations or struggles with barriers such as teacher resistance (Gibson, 2005; Gibson, 2006; Davis\& Harris, 2003; Kissel et al., 2011; Mangin \& Stoelinga, 2011; McKinney \& Girogis, 2009; Smith, 2007), but do not consider them as an essential element of analysis. 
Teachers' emotions are most often considered in relation to whether they resist or value literacy coaching (Matsumura et al., 2010). For instance, Otaiba et al. (2008) noted that teachers felt overwhelmed by the pressures of learning a new reading program and participating in professional development activities. In Buell et al.'s (2010) qualitative study of three Head Start sites that were implementing literacy coaching as part of the Early Reading First Project, they noted that the relationships between teachers and coaches were "highly personal and expressed more on emotive dimensions such as trust and guidance rather than the more emotion neutral description of peer-to-peer feedback" (p. 49) common in previous research on literacy coaching in elementary settings.

Although emotions are mentioned in many studies, they are rarely a primary focus of the research. One notable exception is Bullough's (2009) case study of a beginning teacher and a new teacher mentor, Barbara. Bullough argued that the experiences of these two professionals "illustrate the tight link that exists between emotion and identity" ( $\mathrm{p}$. 43). The study highlighted Barbara's emotional labor as she strived to enact a new professional identity as nurturer. Bullough concluded that it is crucial to consider teachers' and mentors' emotions so that they can flourish in their daily practice. In another study focusing on emotions, Darby (2008) noted that teachers involved in a school-university partnership for school reform felt fear and intimidation during their initial interactions with university faculty and the school-based literacy coach. Over time, however, they felt more positive emotions such as pride and gratitude as their students' achievement scores increased and they felt a greater sense of self efficacy.

Given the tensions that are inherent in literacy coaching, it is important to consider the role emotions play in the interactions between literacy coaches and teachers. 
To do so, it can be helpful to draw on existing research on teacher emotions (Hargreaves, 2001; Schutz \& Zembylas, 2009; Zembylas, 2005a, 2005b). More specifically, it is increasingly valuable to examine emotions in teachers' lives and work especially in the context of high-stakes accountability and reform (Schutz \& Zembylas, 2009). Since literacy coaching is an outgrowth of the current educational climate, it may be worthwhile to investigate how power and positioning within accountability structures impacts teachers' and coaches' "emotional labor" (Hargreaves, 2001). As Schutz and Zembylas (2009) argued, "there is often an underestimation of the complexity of teaching: teaching is often perceived as a rational activity, but the emotional complexity of teaching is neglected" (p. 10). Literacy coaching is emotionally complex as well, so it is essential to examine the role of emotions in coaches' work and interactions with teachers if it is to be a successful endeavor.

\section{Summary}

Although much attention has been paid to coaching in the field of literacy research in the last few years, there remains a large degree of confusion and disagreement among teachers, administrators, coaches, and researchers about the purposes of literacy coaching. This lack of consensus means that coaches, teachers, and administrators must negotiate their understandings of how, where, when, and why professional learning should occur. Such social negotiations are inherently rife with issues of power, positioning, and identity, yet these topics are rarely addressed by researchers or practitioners. More research is needed into the complexities of literacy coaching and the relationships between literacy coaches and teachers in order to understand how 
successful, collaborative spaces for meaningful professional development and enhanced student learning can be co-constructed.

As I illustrate in coming chapters, such negotiations were present in the interactions between the coaches and teachers in this study, and they occurred in relation to dominant Discourses concerning best practices, development, collaboration, and credibility. These Discourses can be found within the review of literature that I have presented in this chapter. For instance, technical coaching aligns with a Discourse of best practices, which suggests that there are best, correct ways of teaching that are universal and that expert, research-based knowledge is more important than teachers' practical knowledge. Moreover, common notions about teacher development as a stepwise progression from novice to veteran are problematic because they position coaches as more expert than teachers (Crafton \& Kaiser, 2011; Hunt \& Handsfield, 2013). Vygotskian concepts of sociocultural development and the ZPD can intensify such expert/novice dyads and complicate collaborative efforts. Finally, Discourses of collaboration and credibility affect coaches' and teachers' shifting positions and identities as they negotiate the local expectations for coaching and work to develop trusting, collaborative relationships. Through microanalysis of such negotiations, I highlight the complexities of coaching interactions and argue that, in order for literacy coaching to reach its full potential, it is vital to acknowledge and work through the ambiguities and uncertainties of collaborative professional learning. 


\section{CHAPTER III \\ RESEARCH DESIGN}

In this chapter, I explain my methods for data collection and analysis and the theoretical framework that supported my choices as a researcher. I employed microethnographic discourse analysis as well as elements of narrative inquiry and critical discourse analysis to explore the overarching question: How do literacy coaches and teachers discursively negotiate issues of identity, power, and positioning during coaching interactions? Based on previous work examining these issues among first-year literacy coaches (Hunt \& Handsfield, 2013), I also explored the following secondary research questions:

1. How do literacy coaches and teachers enact emotions in their discursive negotiations of identity, power, and positioning?

1. How are physical, social, and ideological spaces shaped by and reflected in interactions between literacy coaches and teachers?

\section{Research Paradigm}

My research was informed by certain assumptions about the nature of being, truth, and knowledge. It is important to carefully consider such assumptions in order to distinguish between paradigms and methods so as to avoid using qualitative methods in a manner that upholds the positivistic research tradition, thus limiting what sorts of knowledge and whose truth counts as legitimate (Collins, 2000; Harrison, MacGibbon, \& 
Morton, 2001). Such an examination can help the researcher form a theoretical base for choosing methods. As Bloome et al. (2005) argued,

The separation of theory from methods results in researchers engaging in unreflected action and holding magical beliefs; that is they conduct research without questioning why they do what they do or how their actions are connected to understandings of knowledge, people, or language. (p. xviii)

In order to avoid such unreflected action, I began by examining my assumptions to lay a solid research paradigm on which to build my methodological plan. A research paradigm is a set of "assumptions, concepts, values, and practices" that makes up "an approach to thinking about and doing research" (Johnson \& Christensen, 2010). Paradigms include the researcher's ontology (understandings about the nature of being and reality), epistemologies (beliefs about the nature of truth and knowledge), and methodologies (approaches for seeking knowledge) (Crotty, 1998; Denzin \& Lincoln, 2000). In the following sections, I outline my assumptions about the co-construction of being and reality through language and other discursive moves, my understandings about the role of power in the construction of knowledge and truth, and how I connect these ideas to literacy research.

\section{The Discursive Co-Construction of Selves and Others}

My research is partially based in social constructionism, which asserts that language and other semiotic resources are the fundamental building blocks of socially constructed understandings about ourselves and the world (Geertz, 1973; Vygotsky, 1962). Within this paradigm, language is not a set of autonomous referents to objects and ideals (Fish, 1990). That is, words do not have meaning apart from our cultural 
understandings and social relationships. As Kamberelis and Dimitriadis (2005) explained, "Language is theorized not as a vehicle for representing an already existent world but as the most powerful means available to human beings for constructing what is 'really real' (Geertz, 1973) and fundamentally meaningful about the world” (p. 36). Thus, language and other semiotic modes aid us in dynamically co-constructing the world around us and positioning ourselves within it. In this sense, knowledge and truth are not objective but are produced through inter-subjective discursive practices within social interactions (Geertz, 1973; Vygotsky, 1962). Even our very beings cannot be reduced to a fixed set of characteristics that mark gender, religion, class, sexual orientation, race, or other social categories (Gee, 1999). Rather, our social identities shift as we position and reposition ourselves within social interactions in various spaces across time and in relation to Gee's (2007) “Big D Discourses" (p. 3).

\section{Truth, Knowledge, and Power}

I further rooted the study in poststructural understandings about the nature of truth and knowledge (deCerteau, 1984; Foucault, 1972). Within this perspective, truth and knowledge are produced and reproduced through complex networks of power and are always political and ideological (Foucault, 1972). As McWilliam (1994) explained, Foucault was concerned with the "struggles of power/knowledge that determine the forms and possible domains of knowledge" (p. 35). He noted how certain understandings of truth and particular ways of knowing have been privileged over others. Similarly, many researchers have noted that other ways of knowing, such as oral traditions, everyday life experiences, and emotions, are often dismissed in favor of traditional scientific claims (Brayboy, 2005; Collins, 2000; deCerteau, 1984; Lutrell, 2003; 
Zembylas, 2005b). I aimed to complicate such power-laden ontologies and epistemologies to allow room for alternative understandings that have the potential to push boundaries and offer new perspectives. For instance, in an effort to trouble the tradition of rationality and scientific observation, I resisted the essentialism inherent in the application of labels and categorization and worked to include emotional and artistic knowing.

These understandings about the nature of being, truth, and knowledge have several implications for my methodological choices. First, when participants are seen as active and agentive co-producers of knowledge, it becomes important to observe their meaning making in action within interactional events. The observation and analysis of moment-to-moment interactions allows the researcher to glimpse how participants “create new meanings, new social relationships, and new futures that eschew the reproductive tendencies of what is and what was" (Bloome et al., 2005, p. xvi). Second, an understanding of the role of language and other semiotic modes in the social construction of meaning warrants a close analysis of the microdiscursive moves that participants use to position themselves and others within socially constructed Discourses about literacy and learning. A microethnographic approach to research is appropriate within such a perspective.

\section{A Microethnographic Approach to Discourse Analysis}

For this dissertation, I employed a microethnographic approach to discourse analysis, which utilizes a social interactional perspective that "combines attention to how people use language and other systems of communication in constructing language and 
literacy events in the classrooms with attention to social, cultural and political processes" (Bloome et al., 2005, p. xv). It is an approach developed by educational researchers such as Erickson (2004) and Bloome et al. (2005) and builds on a large variety of research traditions such as New Literacy Studies (e.g. Barton \& Hamilton, 1998; Heath, 1983; Street, 1998), interactional sociolinguistics (Gumperz, 1986), ethnomethodology (e.g. Baker, 1993; Mehan, 1979), conversational analysis (Sacks, Schegloff, \& Jefferson, 1974), critical discourse analysis (Gee, 1999; Fairclough, 1995), Russian literary theory (Bakhtin, 1935/1981, Volosinov, 1929/1973), and French poststructuralism (DeCerteau, 1984).

A microethnographic approach to discourse analysis has been used with some variation by several educational researchers (Bloome et al., 2005; Botzakis, 2008; Erickson, 2004; Green \& Wallat, 1981; Handsfield et al., 2010; Heron-Hruby, Hagood \& Alvermann, 2008; Hunt \& Handsfield, 2013; Kim, 2103; Larson \& Gatto, 2004; Seloni, 2008). There are, however, main tenets which are typically included in microethnographic research (LeBaron, 2005). First, microethnography centers on audio or video recordings of literacy events that occur naturally within the course of participants' everyday lives (Erickson, 2004; Bloome et al., 2005). A literacy event is a "bounded series of actions and reactions that people make in response to each other at the level of face-to-face interaction" in which they co-construct and negotiate meaning and significance surrounding literacy practices as understood by the participants (Bloome et al., 2005, p. 6). Secondly, microethnographers select brief, bounded literacy events, sometimes called small stories (Bamberg, 2004; Juzwik \& Ives, 2010; LeBaron, 2005), that are particularly rich in meaning and significance. The boundaries of these literacy 
events or small stories are socially constructed, must be actively maintained, and are contestable (Bloome et al., 2005). In order to identify the boundaries of these literacy events, which are constructed at different levels, the researcher must pay close attention to how the participants construct thematic coherence. That is, we must ask what the event is about and what the participants are talking about. As such, these literacy events are bounded topically and by participants' intentions and expectations (Bloome et al., 2005). After identifying significant stretches of interaction based on these criteria, detailed transcriptions are constructed that include speech and nonverbal behaviors. Lastly, the detailed transcripts are scrutinized with a close analysis of how participants use language and other communicative resources to co-create meaning and to position themselves within a social order (Bamberg, 2004; Bloome et al., 2005; Erickson, 2004). For the purpose of the current study, I applied these foundational concepts about literacy events to video-recorded interactions between coaches and teachers, which I refer to as coaching events.

A microethnographic approach is appropriate for answering my research questions for two primary reasons. First, it is a valuable tool for connecting micro-level, everyday interactions with classrooms and schools to macro-level policies and ideologies (Bloome et al., 2005; Erickson, 2004). While the social interactions of everyday life are unique, they are influenced and have influence on processes and ideals beyond the immediate context of the classroom (Erickson, 2004). Microethnographic discourse analysis, through its attention to intertextuality and interdiscursivity, allows for a greater understanding of this interplay between the local and the global. 
Secondly, microethnographic discourse analysis is an appropriate tool for examining complicated issues such as power and identity within everyday interactions (Bloome et al., 2005). A close focus on people's language in use within everyday interactions highlights tactical negotiations (Handsfield et al., 2010) -- that is, people's efforts to position themselves and others as certain kinds of people and to construct particular meanings in relation to dominant and marginalized ideologies. Through this micro analysis of language in use, researchers can acknowledge the personal agency that people have despite the top-down forces of policies, ideologies, and other institutional structures. As Bloome et al. (2005) explained, "Every event provides opportunities for people to create new meanings, new social relationships, and new futures that eschew the reproductive tendencies of what is and what was" (p. xvi). Such microanalyses of socially co-constructed meanings require an in-depth understanding of the contexts in which everyday interactions are situated.

\section{Research Setting}

The current study was situated within a large elementary school district in a midsize suburb in the U.S. Midwest to which I had ties as a former employee. The district consisted of ten schools, including six elementary schools (grades K-3), two intermediate schools (grades 4-6), and two junior high schools (grades 7-8). The student population was $93.6 \%$ White and 50\% low income, and the total student enrollment at the time of the study was approximately 3,400 . The district faculty population was $98.4 \%$ White and 88.7\% female with an average of 13.7 years of teaching experience. There were ten school-based literacy coaches in the district, one for each school building, and two 
district-wide literacy coaches, who supported the school-based literacy coaches and acted as intermediaries between schools and district administrators.

The school district had recently implemented literacy coaching within the Partnerships of Comprehensive Literacy Model (PCL). PCL is a school reform model that originated at the University of Arkansas at Little Rock and aims to increase student achievement through the implementation of a workshop model for core instruction and a layered model of intervention. PCL has four main components: a classroom literacy framework which includes balanced literacy methods such as guided reading and writing workshop, school-embedded professional development, intervention programs for struggling readers, and accountability and research. School-embedded professional development is provided by literacy coaches who collaborate with teachers to improve classroom literacy learning, design instruction based on ongoing assessment data, and provide interventions for students who are struggling with the general curriculum (www.arliteracymodel.com).

\section{Participants}

The primary participants were two school-based literacy coaches and seven teachers. Two principals and two district-wide literacy coaches were included in the study as secondary participants. I obtained permission from district administration to speak with the literacy coaches and their principals at a previously scheduled meeting to invite them to participate in the study. In order to conduct research in the school, I needed the consent of both the principal and the school's literacy coach. Out of the ten schools, two principal/literacy coach pairs agreed to participate in the study. Next, I attended faculty meetings at each of the two schools, Westfield Primary School and Norwood 
Middle School (all people and place names are pseudonyms), to explain the study to teachers and invite them to participate.

Westfield Primary School served 304 students in Kindergarten through third grade. Ninety-three percent of the students were white and $64 \%$ were classified as low income. The school had received honors from the state for being a high performing, high poverty school as assessed by standardized state tests. Grace was the literacy coach at Westfield. At the time of the study, it was her third year as a literacy coach and her third year at the school. Grace was a white, middle-class female in her late thirties with 10 years of teaching experience and a Masters degree in administration. Two teachers from Westfield agreed to participate in the study. Katie was a white, middle-class $2^{\text {nd }}$ grade teacher in her late thirties who had taught at Westfield for 16 years and held a Masters degree in Reading. Sophie was a white, middle-class woman in her late twenties who was a first-year teacher assigned to the first grade.

Norwood Middle School served nearly 400 students in the seventh and eighth grades. Approximately $92 \%$ of the students were white, and $46 \%$ were classified as low income. The school had met adequate yearly progress with approximately $85 \%$ of their students meeting or exceeding standards in reading and math. Sarah was the literacy coach at Norwood Middle School. At the time of the study, it was her first year as a literacy coach at that school, but she had previously served as a district literacy coach for three years. She was a white, middle class literacy coach in her forties with 22 years of teaching experience and a Masters degree in Reading. The majority of her experience was spent as a sixth grade teacher at another school in the district. As such, she had a long 
history within the district and pre-existing relationships with many of the teachers in her new school.

Seven teachers from Norwood volunteered to participate in the study: Tiffany, Luke, Amy, Nina, Danielle, Lindsey, and Nicole. I conducted initial interviews with all seven teachers. However, I discovered during initial interviews that Lindsey and Nicole rarely worked with Sarah. I did not want her to schedule literacy coaching interactions with these two teachers solely for the research study, so I included them as secondary participants and did not conduct further observations or interviews with them. Lindsey was a white, middle class teacher in her late twenties, who had been teaching seventh grade language arts for three years. Nicole was a white, middle class art teacher in her thirties with six years of experience.

There were five teachers from Norwood who were primary participants in the study. Tiffany was a white, middle class, first year special education teacher in her early twenties and taught seventh and eighth grades. Luke was a white, middle class, secondyear teacher who taught social studies and language arts to seventh and eighth graders. Amy was a white, middle class teacher in her early thirties who taught seventh and eighth grade math in the special education department. She had six years of teaching experience, but it was her first year in the district. She had a Masters degree in special education and began pursuing her doctoral degree in special education during the study. Nina was a white, middle-class, special education social studies teacher with 20 years of teaching experience at Norwood. Danielle was a white, middle class, special education science teacher in her thirties with eight years of teaching experience. The primary participants 
from both schools will be described in more detail along with my analyses in chapters four through six. See Table 3.1 for a list of participant information.

\begin{tabular}{|c|c|c|c|c|}
\hline Participan & Information & & & \\
\hline School & Pseudonym & Role & $\begin{array}{c}\text { Years of } \\
\text { Experience }\end{array}$ & Gender \\
\hline $\begin{array}{l}\text { Westfield } \\
\text { Primary } \\
\text { School }\end{array}$ & $\begin{array}{l}\text { Grace } \\
\text { Katie } \\
\text { Sophie } \\
\text { Donna } \\
\text { Helen }\end{array}$ & $\begin{array}{l}\text { Literacy Coach } \\
2^{\text {nd }} \text { Grade Teacher } \\
1^{\text {st }} \text { Grade Teacher } \\
\text { Principal } \\
\text { District Literacy Coach }\end{array}$ & $\begin{array}{c}10 \\
16 \\
1 \\
19 \\
28\end{array}$ & $\begin{array}{l}F \\
F \\
F \\
F \\
F\end{array}$ \\
\hline $\begin{array}{l}\text { Norwood } \\
\text { Middle } \\
\text { School } \\
\text { (All } \\
\text { teachers } \\
\text { teach } \\
\text { both } 7^{\text {th }} \\
\text { and } 8^{\text {th }} \\
\text { grades) }\end{array}$ & $\begin{array}{l}\text { Sarah } \\
\text { Tiffany } \\
\text { Luke } \\
\text { Amy } \\
\text { Nina } \\
\text { Danielle } \\
\text { Lindsey } \\
\text { Nicole } \\
\text { Larry } \\
\text { Jodi }\end{array}$ & $\begin{array}{l}\text { Literacy Coach } \\
\text { Resource Language Arts } \\
\text { Teacher } \\
\text { Language Arts and Social } \\
\text { Studies Teacher } \\
\text { Resource Math Teacher } \\
\text { Resource Social Studies Teacher } \\
\text { Instructional Science Teacher } \\
\text { Language Arts Teacher } \\
\text { Art Teacher } \\
\text { Principal } \\
\text { District Literacy Coach }\end{array}$ & $\begin{array}{c}22 \\
1 \\
2 \\
\\
6 \\
20 \\
8 \\
3 \\
6 \\
16 \\
23\end{array}$ & $\begin{array}{l}\text { F } \\
\text { F } \\
M \\
\text { F } \\
\text { F } \\
\text { F } \\
\text { F } \\
\text { F } \\
\text { M } \\
\text { F }\end{array}$ \\
\hline
\end{tabular}

The principals were included in the study as secondary participants because administrators often make significant contributions to how professional learning and collaboration occurs within schools. Donna had been the principal at Westfield for six years. She was a white, middle-class woman in her late fifties. The principal at Norwood was Larry, a white, middle-class male in his fifties who had served as the principal for eight years. The two district literacy coaches, Jodi and Helen, were also included as secondary participants because they interacted regularly with the coaches and teachers 
within the schools and offered directives and advice to the literacy coaches about how to promote professional learning among the teachers. They were both white, middle-class women in their late forties with over twenty years of experience in the district as teachers and instructional leaders.

\section{Researcher Positionality}

Since I worked in the district for a year and knew many of the participants prior to the study, it was especially important for me to examine my own positionality. All researchers have subjectivities, or situational identities that they perform as they interact in the field and analyze and interpret what they see and hear (Glesne, 2006). Whether they actively reflect on it or not, researchers' perceptions and interpretations are affected by personal characteristics and experiences and by their assumptions about truth and knowledge (Chiseri-Strater, 1996; Peshkin, 1988; Pillow, 2003). Subjectivites, as Peshkin (1988) explained, can be both helpful and problematic. For instance, it was helpful that I was similar in age, gender and race to the literacy coaches and that, as a former literacy coach and employee in the research setting, I had prior knowledge of the school district, its programs and goals, and interpersonal politics. Such knowledge was helpful because it deepened my understandings of the local context. On the other hand, my pre-established feelings about district policies and my relationships with former colleagues likely affected how I interpreted what I saw and heard in the field.

These subjectivities, rather than being something to avoid as in the positivistic tradition, should be actively explored so that researchers may attempt to identify the ways in which they enable and disable their ability to understand and represent those they study (Peshkin, 1988). As Glesne (2006) stated, "awareness of your subjectivities can guide 
you to strategies to monitor those perspectives that might, as you analyze and write up your data, shape, skew, distort, construe, and misconstrue what you make of what you see and hear" (p. 123). Therefore, researchers' reflexive examination of their own subjectivities is an important element of data generation, analysis, and representation (Auerbach \& Silverstein, 2001).

With these precepts in mind, I reflexively examined my subjectivities in a variety of ways. I began by including my feelings and reactions to what I saw and heard during observations and interviews in my field notes (Glesne, 2006). As Kleinman (1991) argued, such attention to emotions can attune researchers to how their values and preconceived notions are affecting what they pay attention to in the field and how they interpret data. I further reflected upon my feelings and reactions in my research journal and, when appropriate, with the participants. I revisited these reflections often in order to increase awareness of how my ideas and interpretations were developing. As Coffey and Atkinson (1996) argued, "It is vital to recognize that the generation of ideas can never be dependent on the data alone. Data are there to think with and to think about" (p. 153). My analytic notes and research journal served as tools for theorizing about the data generated and for documenting my thinking throughout the research process.

As researchers working from a poststructural feminist perspective (Lather, 1991; Pillow, 2003) have pointed out, being reflexively aware of subjectivities as researchers does not exonerate us from the ethical issues that arise because of them. Pillow (2003) argued for "uncomfortable reflexive practices" in which the researcher "seeks to know while at the same time situates this knowing as tenuous" (Pillow, 2003, p. 188). She suggested that the goal of reflexivity should be to improve accountability to the research 
participants rather than to claim a more accurate representation of the other. As such, it is important to embrace the messiness of qualitative research and to move towards the unfamiliar and the uncomfortable.

This messiness was present throughout this study as I struggled with tensions related to the incongruence between the comfortable stories coaches, teachers and administrators told about literacy coaching in interviews and the uncomfortable unfolding stories told within their in-the-moment interactions. I felt confused and somewhat guilty that the positionings I saw within the coaching interactions conflicted with the overall sense of trust, respect, success and pride that the participants felt in their professional development work. I was afraid that the coaches would feel that I was judging them, and perhaps they did; but one way of working through the messiness was to maintain open communication about my findings despite my fears. It also helped to accept the simultaneous nature of social positionings and to recognize that both stories could be true at the same time. In writing my findings, I have attempted to communicate that my research story presents only one of many possible perspectives on the literacy coaches' work and to acknowledge that, as the researcher, I am also subject to and enact certain Discourses and social positionings.

Moreover, the microethnographic approach urges researchers to consider the power relationships between the researcher and the participants. For instance, Bloome et al. (2005) advocated for an "increased reflexivity" which acknowledges that Discourses of research and academia can influence or impose interpretations that are not in line with the perspectives of the participants. They argued that it is essential that "we ask who is doing what, to whom, where, and how through the use of language in classrooms, and we 
ask that of ourselves as well" (p. 49). There were definitely times throughout this study when I felt that my position as the researcher influenced the way that the participants interacted with me and with each other. For instance, after interviewing participants, they would often make comments such as, "I hope you got what you wanted," and a couple of teachers expressed a fear of "sounding stupid." At times, it seemed that the coaches and teachers tried to interpret my expectations and opinions so that they could tell me what they thought I wanted to hear or figure out what stories I was constructing about them. In my final interview with Sarah, it was evident that she had talked to people I interviewed before her, specifically a teacher and the district literacy coach, because she brought up topics and questions from those interviews without my prompting. In short, the participants cared what I thought about them and their practice, and that may have affected how they interacted in my presence.

\section{Data Sources}

I employed ethnographic and microethnographic methods to generate data over a period of eight months. Data generation procedures included participant observations, semi-structured interviews, video-taped observations of coaching interactions, and artifact collection. See Table 3.2 for the research timeline that I followed.

\section{Table 3.2}

Research Timeline

\begin{tabular}{|l|ll|l|}
\hline \multicolumn{1}{|c|}{ Month } & \multicolumn{1}{c|}{ Task } & \multicolumn{1}{c|}{ Analysis } \\
\hline August & $\bullet$ & Proposal Hearing & \\
\hline September & $\bullet$ & Obtain IRB Approval & Obtain permissions from \\
& & $\begin{array}{l}\text { district and school } \\
\text { administration }\end{array}$ & $\bullet$ Writing up field notes. \\
& $\bullet \begin{array}{l}\text { Recruit participants and } \\
\text { obtain informed }\end{array}$ & & \\
\hline
\end{tabular}




\begin{tabular}{|c|c|c|}
\hline & $\begin{array}{ll}\text { - } & \text { Establish Rapport } \\
\text { - } & \text { Begin weekly visits to } \\
\text { school and taking field } \\
\text { notes. }\end{array}$ & \\
\hline October & $\begin{array}{l}\text { - Interviews with coaches } \\
\text { and principals, } \\
\text { - Weekly observations and } \\
\text { field notes. }\end{array}$ & $\begin{array}{ll}\text { - } & \text { Writing up field notes. } \\
\text { - } & \text { Coding field notes } \\
& \text { joulytic notes in research } \\
\text { - } & \text { Transcribing Interviews } \\
\text { - } & \text { Coding Interviews. } \\
\text { - } & \text { Constant Comparative } \\
& \text { Analysis (CCA) }\end{array}$ \\
\hline November & $\begin{array}{l}\text { - Weekly observations and } \\
\text { field notes. } \\
\text { - Interviews with teachers }\end{array}$ & $\begin{array}{ll}\text { - } & \text { Writing up field notes. } \\
\text { - } & \text { Coding field notes } \\
\text { - } & \text { Analytic notes in research } \\
& \text { journal. } \\
\text { - } & \text { Transcribing Interviews } \\
\text { - } & \text { Coding Interviews. } \\
\text { - } & \text { CCA }\end{array}$ \\
\hline December & $\begin{array}{l}\text { - Weekly observations and } \\
\text { field notes. } \\
\text { - Interviews with teachers }\end{array}$ & $\begin{array}{ll}\text { - } & \text { Writing up field notes. } \\
\text { - } & \text { Coding field notes } \\
\text { - } & \text { Analytic notes in research } \\
& \text { journal. } \\
\text { - } & \text { Transcribing Interviews } \\
\text { - } & \text { Coding Interviews. } \\
\text { - } & \text { CCA }\end{array}$ \\
\hline January & $\begin{array}{l}\text { - Weekly observations and } \\
\text { field notes. } \\
\text { - Videotaped observations } \\
\text { of coach/teacher } \\
\text { interactions } \\
\text { - Video debriefing } \\
\text { Interviews }\end{array}$ & $\begin{array}{ll}\text { - } & \text { Writing up field notes. } \\
\text { - } & \text { Coding field notes } \\
\text { - } & \text { Analytic notes in research } \\
& \text { journal. } \\
\text { - } & \text { Transcribing Interviews } \\
\text { - } & \text { Coding Interviews. } \\
\text { - } & \text { CCA } \\
\text { - } & \text { Microethnographic } \\
& \text { transcription and analysis of } \\
& \text { selected video segments. }\end{array}$ \\
\hline February & $\begin{array}{l}\text { Weekly visits and field } \\
\text { notes. } \\
\text { - Videotaped observations } \\
\text { of coach/teacher } \\
\text { interactions } \\
\text { - Video debriefing }\end{array}$ & $\begin{array}{ll} & \text { Writing up field notes. } \\
\text { - } & \text { Coding field notes } \\
\text { - } & \text { Analytic notes in research } \\
& \text { journal. } \\
\text { - } & \text { CCA } \\
\text { - } & \text { Microethnographic }\end{array}$ \\
\hline
\end{tabular}




\begin{tabular}{|c|c|c|}
\hline & Interviews & $\begin{array}{l}\text { transcription and analysis of } \\
\text { selected video segments. }\end{array}$ \\
\hline March & $\begin{array}{l}\text { - Weekly observations and } \\
\text { field notes. } \\
\text { - Videotaped observations } \\
\text { of coach/teacher } \\
\text { interactions } \\
\text { - Video debriefing } \\
\text { Interviews }\end{array}$ & $\begin{array}{ll}\text { - } & \text { Writing up field notes. } \\
\text { - } & \text { Coding field notes } \\
\text { - } & \text { Analytic notes in research } \\
\text { journal. } \\
\text { - } & \text { CCA } \\
\text { - } & \text { Microethnographic } \\
\text { transcription and analysis of } \\
\text { selected video segments. }\end{array}$ \\
\hline April & $\begin{array}{l}\text { - Weekly observations and } \\
\text { field notes. } \\
\text { - Videotaped observations } \\
\text { of coach/teacher } \\
\text { interactions } \\
\text { - Video debriefing } \\
\text { Interviews } \\
\text { - Final Interviews with } \\
\text { coaches, principals and } \\
\text { teachers }\end{array}$ & $\begin{array}{l}\text { - Writing up field notes. } \\
\text { - } \text { Coding field notes } \\
\text { - } \text { Analytic notes in research } \\
\text { journal. } \\
\text { - } \text { Transcribing Interviews } \\
\text { - Coding Interviews. } \\
\text { - CCA } \\
\text { - Microethnographic analysis of } \\
\text { video segments and possibly } \\
\text { Interview segments. }\end{array}$ \\
\hline May & $\begin{array}{l}\text { - Final Interviews with } \\
\text { coaches, principals and } \\
\text { teachers }\end{array}$ & $\begin{array}{ll}\text { - } & \text { Writing up field notes. } \\
\text { - } & \text { Coding field notes } \\
\text { - } & \text { Analytic notes in research } \\
& \text { journal. } \\
\text { - } & \text { Transcribing Interviews } \\
\text { - } & \text { Coding Interviews. } \\
\text { - } & \text { CCA } \\
\end{array}$ \\
\hline $\begin{array}{l}\text { June- } \\
\text { September }\end{array}$ & \multicolumn{2}{|l|}{$\begin{array}{ll}\text { - } & \text { Further analysis of data set. } \\
\text { - } & \text { Member checks } \\
\text { - } & \text { Writing/Revising Dissertation } \\
\end{array}$} \\
\hline
\end{tabular}

\section{Observations}

Over a period of eight months, from October 2012 to May 2013, I conducted approximately one participant observation per week of each literacy coach's work with teachers during one-on-one teacher-coach interactions, classroom activities, and professional meetings. I spent two to five hours one day per week in each of the 
participating schools in an effort to gain a holistic view (Dewalt \& Dewalt, 2002) of the coaches' and teachers' professional contexts and working relationships and to build rapport, trust, and reciprocity. I observed in a variety of settings depending on the coaches' varying and flexible schedules. At Norwood, I primarily observed departmental and team meetings, professional book studies, leadership meetings, and Sarah working with individual teachers in and out of classrooms. At Westfield, most of my observations occurred on Fridays, which were set aside for coaching sessions with grade level teams. I also observed school-wide improvement meetings, Grace working with individual teachers in her office and in their classrooms, and problem solving meetings in which she assisted the teachers with making decisions about interventions for students.

During this time, I adopted a variety of observer stances (Adler \& Adler, 1994; Kawulich, 2005; Spradley, 1980) depending on the activity being observed and the participants' level of comfort with my participation (Dewalt \& Dewalt, 2002). For observations of classrooms and professional meetings, I took a peripheral (Adler \& Adler, 1994), passive (Spradley, 1980) stance in which I observed activities within the setting but with minimal participation. The purpose of these observations was to develop understandings about how the literacy coaches and teachers interacted in their day-to-day work and, as such, active participation on my part was unnecessary. In these instances, I used an observation protocol (Creswell, 2009) for recording detailed field notes. The protocol consisted of a two-column notebook for recording both descriptive and analytic notes (Glesne, 2006). The descriptive notes focused on the interactions between coaches and teachers, and I documented verbatim speech and other communicative moves such as body positionings, gestures, tone, and expression. Analytical notes included my initial 
thoughts and interpretations, notes about connections to other data, and clarifying questions that I wanted to ask the coaches or teachers.

At times I took a more active (Adler \& Adler, 1994), moderate (Spradley, 1980) stance and contributed to conversations. For instance, I often attended the weekly leadership meetings that were held at Norwood and attended by Sarah, the principal, and a district literacy coach. At times, they asked my opinion about instructional issues or leadership decisions. I also participated in two professional book studies. One occurred at Norwood every Thursday morning for seven weeks. A group of eight teachers signed up to read and discuss Choice Words by Peter Johnston (2004). During these weekly morning meetings, Sarah facilitated the discussions of each chapter, and I often joined in on the conversations. I also participated in a book study that took place as part of monthly district-wide literacy coach meetings. We read and discussed Student-Centered Coaching: A Guide for K-8 Coaches and Principles by Diane Sweeney (2011) and Pathways to the Common Core: Accelerating Achievement by Calkins, Ehrenworh, and Lehamn (2012). These more informal observations allowed me to immerse myself in a wider spectrum of the coaches' daily activities in order to gain "access to the fluidity of others' lives" and to enhance my "sensitivity to interaction and process" (Emerson, Fretz \& Shaw, 1995, p. 2). When working from an active observation stance, I took field notes in the form of "headnotes" and "jottings" (Emerson et al., 1995, p. 19). I recorded brief descriptive notes in a small notebook, which freed me to engage more fully and authentically in the literacy coaches' and teachers' daily work routines.

For each type of observation, I typed full field notes within a forty-eight hour period. These field notes included expansions of the descriptive and analytic notes 
recorded on the observation protocol or jotted in my field notebook as well as extended reflective analysis of the day's events and interactions. I used the field notes to create a "thick description" (Geertz, 1973, pg. 6) of the interactions between coaches and teachers throughout the day. Furthermore, I used my notes to develop questions for follow-up interviews and to inform subsequent observations.

\section{Video Recorded Observations}

In order to obtain a "visual document for thick description" (Rosenstein \& Sheva, 2002, p. 24) and close discursive analysis, I digitally video recorded five literacy coaching interactions. At Norwood, I recorded three videos of Sarah working with teachers. In the first video, Sarah met with Tiffany, a first-year special education teacher, to co-plan a writing workshop lesson. In the second video, Sarah facilitated a meeting in which five special education teachers watched and discussed videos of teachers conferring with students in reading and science. In the final video, Sarah met with Luke, a second-year social studies and language arts teacher, to debrief about a unit that they had planned and taught together. At Westfield, I collected two videos of Grace interacting with teachers. In one video, Grace met with Sophie, a first year teacher, to watch and review a video of writing workshop in Sophie's $1^{\text {st }}$ grade classroom. Grace took the second video herself, which was of an impromptu meeting with Katie, a second grade teacher, about how to encourage students to use new strategies in their independent writing. See Table 3.3 for further information about the video recordings. 


\begin{tabular}{|c|c|c|c|c|}
\hline \multicolumn{5}{|c|}{\begin{tabular}{|l|} 
Table 3.3 \\
Video Recordings
\end{tabular}} \\
\hline School & Date & Participants & Activity & Videographer \\
\hline \multirow[t]{2}{*}{$\begin{array}{l}\text { Westfield } \\
\text { Primary } \\
\text { School }\end{array}$} & $3 / 19 / 13$ & $\begin{array}{l}\text { Grace } \\
\text { Katie }\end{array}$ & $\begin{array}{l}\text { Informal } \\
\text { Instructional } \\
\text { Conversation }\end{array}$ & Grace \\
\hline & $4 / 25 / 13$ & $\begin{array}{l}\text { Grace } \\
\text { Sophie }\end{array}$ & $\begin{array}{l}\text { Post- } \\
\text { Observation } \\
\text { Reflection }\end{array}$ & Carolyn \\
\hline \multirow[t]{3}{*}{$\begin{array}{l}\text { Norwood } \\
\text { Middle } \\
\text { School }\end{array}$} & $1 / 23 / 13$ & $\begin{array}{c}\text { Sarah } \\
\text { Tiffany } \\
\text { Amy } \\
\text { Nina } \\
\text { Danielle }\end{array}$ & $\begin{array}{l}\text { Special } \\
\text { Education } \\
\text { Department } \\
\text { Meeting }\end{array}$ & Carolyn \\
\hline & $1 / 29 / 13$ & $\begin{array}{l}\text { Sarah } \\
\text { Tiffany }\end{array}$ & $\begin{array}{l}\text { Co-Planning } \\
\text { Session for } \\
\text { Writing } \\
\text { Workshop }\end{array}$ & Carolyn \\
\hline & $4 / 9 / 13$ & $\begin{array}{l}\text { Sarah } \\
\text { Luke }\end{array}$ & $\begin{array}{l}\text { Reflective } \\
\text { Discussion } \\
\text { about Co-taught } \\
\text { Social Studies } \\
\text { Unit }\end{array}$ & Carolyn \\
\hline
\end{tabular}

Such video recordings, when used in concert with other ethnographic methods, are a valuable tool for educational research (Erickson, 1992) because they allow the researcher to revisit an event in order to conduct multiple levels of analysis on a variety of scales from the individual to the collective (Baker, Green, \& Skukauskaite, 2008). Obtaining video data is not as simple, however, as focusing a camera lens on participants. The perspective that a camera provides is always contingent upon the methods of videography (LeBaron, 2005). There are many "cinematic decisions" that can affect the quality of the data such as when to turn the camera on and off and what scope to include in the frame (LeBaron, 2005). As such, I carefully chose my methods of camera placement and positioning. Since the interactions that I recorded all occurred around 
tables or desks with minimal movement, it made sense to secure the camera on a tripod and keep the frame constant. I was careful to frame the scene so that all the participants' faces and bodies could be clearly seen. I zoomed in as close as possible while still maintaining the appropriate scope, which allowed for the analysis of details such as facial expressions. For the most part, these filming decisions were effective, but occasionally a coach or teacher would move out of the frame momentarily, preventing the analysis of their movements and gestures.

\section{Semi-structured Interviews}

I conducted semi-structured interviews (Mertens, 1998) with the literacy coaches, teachers, principals and district literacy coaches two to three times throughout the study. All interviews lasted approximately forty-five to sixty minutes and were audio recorded and transcribed verbatim by me. The interviews occurred in the setting of the participants' choosing, most often an office or classroom. My goal was to conduct the interviews in an environment in which each participant felt the most comfortable and to be flexibly considerate of their busy schedules.

I conducted initial, individual, semi-structured interviews with the coaches and teachers during the fall semester of 2012 that focused on their expectations for each other, their goals for professional learning, their existing relationships, and their experiences with literacy coaching. I interviewed seven teachers at Norwood and two teachers at Westfield. At Norwood, these initial interviews revealed that the teachers worked in different capacities with Sarah. Luke and Tiffany worked with Sarah on a weekly, and sometimes daily, basis because of their status as novice teachers; therefore, I chose them to be primary participants who I would video record working individually 
with Sarah and then interview two more times. The remaining three teachers only occasionally worked with Sarah on an individual basis but met with her at least twice a month as a group. Since the entire special education department agreed to participate in the study, I was able to record them in a small-group coaching interaction. I included them as primary participants but only interviewed them one more time, at the end of the study. Nicole and Lindsey rarely worked with Sarah, so I did not have the opportunity to video record any coaching interactions with them and did not conduct further interviews with them. See table 3.4 for an overview of the interviews conducted with teachers.

\begin{tabular}{|c|c|c|c|c|c|}
\hline \multicolumn{6}{|c|}{$\begin{array}{l}\text { Table } 3.4 \\
\text { Teacher Interviews }\end{array}$} \\
\hline School & Participant & $\begin{array}{l}\text { Initial } \\
\text { Interview }\end{array}$ & $\begin{array}{l}\text { Video- } \\
\text { Recorded } \\
\text { Interaction }\end{array}$ & $\begin{array}{l}\text { Paired } \\
\text { Interview }\end{array}$ & $\begin{array}{l}\text { Final } \\
\text { Interview }\end{array}$ \\
\hline \multirow{7}{*}{$\begin{array}{l}\text { Norwood } \\
\text { Middle School }\end{array}$} & Tiffany & $\mathrm{x}$ & $\mathrm{x}$ & $\mathrm{x}$ & $\mathrm{x}$ \\
\hline & Luke & $\mathrm{x}$ & $\mathrm{x}$ & $\mathrm{x}$ & $\mathrm{x}$ \\
\hline & Amy & $\mathrm{x}$ & x (group) & & $\mathrm{x}$ \\
\hline & Nina & $\mathrm{x}$ & x (group) & & $\mathrm{x}$ \\
\hline & Danielle & $\mathrm{x}$ & x (group) & & $\mathrm{x}$ \\
\hline & Lindsey & $\mathrm{x}$ & & & \\
\hline & Nicole & $\mathrm{x}$ & & & \\
\hline Westfield & Sophie & $\mathrm{x}$ & $\mathrm{x}$ & $\mathrm{x}$ & $\mathrm{x}$ \\
\hline Primary & Katie & $\mathrm{x}$ & $\mathrm{x}$ & $\mathrm{x}$ & $\mathrm{x}$ \\
\hline School & & & & & \\
\hline
\end{tabular}

I conducted a second interview with literacy coach/teacher pairs around the viewing of the videos of individual literacy coaching interactions. I interviewed Sarah 
individually about the video of the special education teachers' small-group meeting because scheduling did not allow for them to all come together to discuss the video with me. I showed the coaches and teachers small segments of video that I identified through initial transcribing, coding, microtranscription, and close analysis. These interviews created an opportunity to engage in initial member checking of my analyses and to gain their perspectives about the interaction in relation to community Discourses. I conducted a final individual interview with each literacy coach and primary teacher participant in the spring semester of 2013 during April and May with questions based on previous interviews and observations.

I also conducted individual, semi-structured interviews with the principals of each school and the two district literacy coaches. These interviews occurred in October 2012 and May 2013 and focused on their expectations of literacy coaches and teachers, their goals for school-wide and district-wide professional development, and their perceptions about literacy coaches' work with teachers. These interviews provided context for understanding what coaching meant within the district and the individual schools, about dominant Discourses circulating in the district, and about local norms for professional collaboration and learning.

\section{Artifacts}

In addition to observation and interview data, I collected artifacts in order and to provide data for contextualization such as historical, demographic, and personal information (Glesne, 2006) and to increase trustworthiness by providing triangulation with observations and interviews. Found artifacts (Glesne, 2006) included items such as meeting agendas, coaching cycle notes, reflective journals, and policy documents. Some 
artifacts were collected as paper documents and some through photography. Such artifacts added to my understanding of the local contexts and, at times, provided valuable insights into how the coaches and teachers co-constructed understandings about professional learning and best practices.

\section{Research Journal}

Throughout the study, I kept a research journal in order to document my own subjectivities, to formulate ideas, and to record initial interpretations. As Peshkin (1988) argued, "By monitoring myself, I can create an illuminating, empowering personal statement that attunes me to where self and subject are intertwined" (p. 20). I wrote in this journal weekly and reread it frequently in order to raise my awareness of my own emotions, fears, and reactions. Such factors shaped my interpretations of the literacy coaches' and teachers' interactions within their daily work. As the researcher, it was important to consider my emotions and fears because they reflect my values and affected my decisions in the field, my interactions with participants, how I framed the data, and what I chose to highlight (Kleinman, 1991; Fine \& Weis, 2000). The research journal was a valuable tool because as researchers "we must write about why we chose the setting, who we are at the moment, and how our identity affects our reactions to the setting and its participants" (Kleinman, 1991, p. 195). See Appendix A for an example of how I used my research journal to reflect on the uncomfortable messiness of my inquiry and my accountability to the participants.

\section{Data Analysis}

I used multiple methodological tools for data analysis, including constant comparative analysis (CCA) (Glaser \& Strauss, 1967; Strauss \& Corbin, 1990), 
microethnographic discourse analysis (Bloome et al., 2005; Erickson, 2004), and small story narrative analysis (Bamberg, 2004). In the first phase of analysis, I transcribed and coded audio recordings of semi-structured interviews in order to generate themes through constant comparative analysis (CCA). Next, I coded the video recordings of coaching interactions and used those codes to select short segments, or coaching events, to transcribe in detail according to microethnographic conventions. In the final phase of analysis, I analyzed the microethnographic transcriptions for narrative structure, discursive moves, and instances of positioning. I connected the small slices of social interaction recorded in the microethnographic transcripts to the themes generated from the larger data set. These phases of analysis did not occur across a strictly linear timeline, but were recursive as I simultaneously engaged in multiple phases throughout the research study.

\section{Phase One}

I transcribed verbatim all digitally recorded audio data in order to provide written text for coding and to recursively generate themes through constant comparative analysis (Glaser \& Straus, 1967). I marked lines of transcripts and field notes to generate grounded codes that were generally topical but included the actual words of the participants when appropriate in order to achieve a low level of inference in identifying the codes (Carspecken, 1996). Examples of specific codes included trying out the frameworks, moving in a positive direction, she's so knowledgeable and common planning time. Next, I categorized these codes based on similarity in a process similar to axial coding (Strauss \& Corbin, 1990). Examples of categories include frameworks and models for best practice, professional development goals, coaches' expertise and 
meetings. Finally, I collapsed the categories into common themes, or Discourses, that circulated among the coaches' professional community: Best Practices, Development, Credibility, and Collaboration. See table 3.5 for examples of the grounded codes and categories and how they relate to the four generated themes. Each of themes will be described in greater detail in Chapter Four.

\begin{tabular}{|c|c|}
\hline \multicolumn{2}{|c|}{ Theme 1: Best Practices } \\
\hline Categories & Examples of Grounded Codes \\
\hline $\begin{array}{l}\text { Frameworks and } \\
\text { Models of Best } \\
\text { Practices }\end{array}$ & $\begin{array}{l}\text { - } \text { Readers Workshop } \\
\text { - Writers Workshop } \\
\text { - The workshop approach } \\
\text { - The architecture of a conference } \\
\text { - Trying out the framework } \\
\text { - Comprehension focus groups } \\
\text { - Guided reading plus groups } \\
\text { - Intervention frameworks } \\
\text { - Dorn's frameworks } \\
\text { - Independent reading component } \\
\text { - Word work component } \\
\text { - } \text { Mini lesson framework }\end{array}$ \\
\hline $\begin{array}{l}\text { District } \\
\text { Initiatives for } \\
\text { Implementing } \\
\text { Best Practices }\end{array}$ & $\begin{array}{l}\text { - They have a consistent, across the board model. } \\
\text { - Curriculum mapping } \\
\text { - } \text { Ongoing professional development through the district } \\
\text { - That is what we have to do now. } \\
\text { - That's what I need to do. } \\
\text { - A systemic approach } \\
\text { - The district is just kind of a guide. }\end{array}$ \\
\hline $\begin{array}{l}\text { Training in Best } \\
\text { Practices }\end{array}$ & $\begin{array}{l}\text { - She [the coach] has a lot of trainings. } \\
\text { - I've been to a lot of trainings. } \\
\text { - They train their teachers correctly in it. } \\
\text { - You actually get trained. } \\
\text { - CIM training }\end{array}$ \\
\hline
\end{tabular}




\begin{tabular}{|c|c|}
\hline & $\begin{array}{l}\text { - } \quad \text { Training in writing workshop } \\
\text { - Literacy coach training } \\
\text { - Reading Recovery training }\end{array}$ \\
\hline $\begin{array}{l}\text { Modeling and } \\
\text { Observation of } \\
\text { Best Practices }\end{array}$ & $\begin{array}{l}\text { - I've been modeling for them. } \\
\text { - I went in and modeled a framework. } \\
\text { - She modeled a conference for us. } \\
\text { - Watching someone teach a lesson } \\
\text { - You show us how conferring is supposed to look like. } \\
\text { - I modeled interactive writing. } \\
\text { - I'm modeling for her what that looks like. }\end{array}$ \\
\hline $\begin{array}{l}\text { Resources about } \\
\text { Best Practices }\end{array}$ & $\begin{array}{l}\text { - I'll bring them resources of examples. } \\
\text { - They see me as a person for resources. } \\
\text { - She helps me find resources. } \\
\text { - She gives us different resources. } \\
\text { - She brings us information. } \\
\text { - These worksheets are all from her. } \\
\text { - She gives us the resources to be successful in interventions. }\end{array}$ \\
\hline \multicolumn{2}{|c|}{ Theme 2: Development } \\
\hline Categories & Examples of Grounded Codes \\
\hline New Teachers & $\begin{array}{l}\text { - New teacher mentoring program } \\
\text { - You're a first year teacher. You can make mistakes. } \\
\text { - Brand new teachers }\end{array}$ \\
\hline $\begin{array}{l}\text { Veteran } \\
\text { Teachers }\end{array}$ & $\begin{array}{l}\text { - I would rather be with a veteran teacher by invitation. } \\
\text { - Two veteran teachers don't do workshop. } \\
\text { - Even a veteran teacher, when trying something new, won't } \\
\text { be perfect at it. }\end{array}$ \\
\hline $\begin{array}{l}\text { Lack of } \\
\text { Experience }\end{array}$ & $\begin{array}{l}\text { - They were like, "I don't know how to do that." } \\
\text { - She had never worked with that grade level. } \\
\text { - She doesn't know the curriculum or the content. } \\
\text { - It was their first time through. } \\
\text { - Three of the teachers have not gone through CIM training. } \\
\text { - I don't have very much writing experience. } \\
\text { - That's new to me. }\end{array}$ \\
\hline $\begin{array}{l}\text { Struggling } \\
\text { Teachers }\end{array}$ & $\begin{array}{l}\text { - She was floundering. } \\
\text { - I'm struggling. } \\
\text { - That's hard for me. }\end{array}$ \\
\hline $\begin{array}{l}\text { Supporting, } \\
\text { Helping and } \\
\text { Scaffolding } \\
\text { Teachers }\end{array}$ & $\begin{array}{l}\text { - We need a little bit more help with how to do it. } \\
\text { - She goes in and helps. } \\
\text { - She's helping us with conferring. } \\
\text { - She was very helpful with planning. } \\
\text { - It's been great having support. }\end{array}$ \\
\hline
\end{tabular}




\begin{tabular}{|c|c|}
\hline & $\begin{array}{l}\text { - She's very emotionally supportive. } \\
\text { - This week she's trying it on her own. } \\
\text { - Gradually letting them be on their own. }\end{array}$ \\
\hline $\begin{array}{l}\text { Teachers at } \\
\text { Different Levels }\end{array}$ & $\begin{array}{l}\text { - Teaching styles are very different } \\
\text { - We have very different levels of implementation. } \\
\text { - } \quad \text { There is a big divide in knowledge and experience. }\end{array}$ \\
\hline $\begin{array}{l}\text { Professional } \\
\text { Development } \\
\text { Goals }\end{array}$ & $\begin{array}{l}\text { - Our goal is conferring. } \\
\text { - I wrote my formal goal. } \\
\text { - They never seem to get their goal. } \\
\text { - Helping us accomplish our goal. } \\
\text { - School Wide Improvement Goals }\end{array}$ \\
\hline $\begin{array}{l}\text { Movement } \\
\text { Towards a Goal }\end{array}$ & $\begin{array}{l}\text { - It started her thinking in a different direction. } \\
\text { - I can help move those interventions along. } \\
\text { - She made sure we were on the right track. } \\
\text { - She will help me get where I need to be. } \\
\text { - We're moving in a positive direction. }\end{array}$ \\
\hline \multicolumn{2}{|c|}{ Theme 3: Credibility } \\
\hline Categories & Examples of Grounded Codes \\
\hline $\begin{array}{l}\text { Roles and } \\
\text { Expectations for } \\
\text { Coaches }\end{array}$ & $\begin{array}{l}\text { - Coaching takes on a lot of faces } \\
\text { - They have an understanding of what the role is supposed to } \\
\text { be. } \\
\text { - They don't always understand the coaching role right away. } \\
\text { - If they group me with anyone, they group me with the } \\
\text { office. } \\
\text { - Specific roles: e.g. mentor, co-teacher, interventionist, etc. }\end{array}$ \\
\hline $\begin{array}{l}\text { Coaches' } \\
\text { Expertise }\end{array}$ & $\begin{array}{l}\text { - Teachers give me a little bit of credulity because I've taught } \\
\text { those subjects. } \\
\text { - She's so knowledgeable. } \\
\text { - She is a really experienced teacher. } \\
\text { - She has a lot of training. }\end{array}$ \\
\hline Trust & $\begin{array}{l}\text { - I'm still building that trust. } \\
\text { - It didn't take me long to trust her. } \\
\text { - I trust her fully. }\end{array}$ \\
\hline $\begin{array}{l}\text { Coaches' } \\
\text { Personalities }\end{array}$ & $\begin{array}{l}\text { - She's very open and warm. } \\
\text { - She's very friendly. } \\
\text { - She's subtle. } \\
\text { - I've always like her. }\end{array}$ \\
\hline $\begin{array}{l}\text { Judgment and } \\
\text { Evaluation }\end{array}$ & $\begin{array}{l}\text { - I'm not here to judge them. } \\
\text { - They don't feel like I'm a threat coming in. } \\
\text { - She doesn't make me feel stupid. } \\
\text { - It's good confirmation when she observes. }\end{array}$ \\
\hline
\end{tabular}




\begin{tabular}{|c|c|}
\hline & - She doesn't say you did all these things wrong. \\
\hline $\begin{array}{l}\text { Listening and } \\
\text { Talking }\end{array}$ & $\begin{array}{l}\text { - } \text { Promoting good conversation } \\
\text { - } \text { I reflect with them. } \\
\text { - We have talked through some ideas. } \\
\text { - Getting out there and being part of conversations. } \\
\text { - We talk about everything. } \\
\text { - She's a great listener. } \\
\text { - We are in constant communication daily. }\end{array}$ \\
\hline $\begin{array}{l}\text { Consistency and } \\
\text { Availability }\end{array}$ & $\begin{array}{l}\text { - I have the credibility of following through with things. } \\
\text { - She's here all the time. } \\
\text { - She'll work it right away. } \\
\text { - Flexible scheduling } \\
\text { - } \quad \text { Anything we ask her, she does. }\end{array}$ \\
\hline \multicolumn{2}{|c|}{ Theme 4: Norms of Collaboration } \\
\hline Categories & Examples of Grounded Codes \\
\hline Meetings & $\begin{array}{ll}\text { - } & \text { Problem Solving Meetings } \\
\text { - } & \text { Weekly Coaching Sessions } \\
\text { - } & \text { Department Meetings } \\
\text { - } & \text { Team Meetings } \\
\text { - } & \text { Grade Level Meetings } \\
\text { - } & \text { School Wide Improvement Plan Meetings } \\
\end{array}$ \\
\hline $\begin{array}{l}\text { Co-planning and } \\
\text { Co-teaching }\end{array}$ & $\begin{array}{l}\text { - Common plan time } \\
\text { - I meet with the coach every Tuesday after school. } \\
\text { - We met during her plan time. } \\
\text { - We planned it all together. } \\
\text { - We kind of took turns doing things. }\end{array}$ \\
\hline $\begin{array}{l}\text { Coach-initiated } \\
\text { Coaching }\end{array}$ & $\begin{array}{l}\text { - With some people, it's hard to start the first ball. } \\
\text { - I approached the teachers. } \\
\text { - Sometimes it's going through the back door. } \\
\text { - I listen to what they're wanting. } \\
\text { - The coaching sessions were just mandated. } \\
\text { - I get out there into meetings and classrooms. }\end{array}$ \\
\hline $\begin{array}{l}\text { Teacher- } \\
\text { initiated } \\
\text { Coaching }\end{array}$ & $\begin{array}{l}\text { - A teacher came to me in response to some modeling. } \\
\text { - I go into her office before or after school. } \\
\text { - We make appointments if I need them. } \\
\text { - We have invited the coach to meetings. }\end{array}$ \\
\hline
\end{tabular}




\section{Phase Two}

In phase two of data analysis, I completed rough transcriptions of the videorecorded coaching interactions. Several researchers have noted that the act of transcription cannot be neatly separated from analysis because researchers make choices about what to note and what conventions to use (Ochs, 1979; Gumperz \& Berenz, 1993). As Lapadat and Lindsey (1999) argued, "Because transcription is inherently selective and this selectivity is based in the knowledge, beliefs, and interpretations of the researcher, researchers must strive to explicate their decision making" (p. 70). Thus, it is important to clearly explain the conventions and processes I used for transcription.

I began by watching the entire coaching interaction in full without stopping the recording, and I took field notes as I would in real time observations (Erickson, 1982). This first viewing provided a sense of "the overall course of action" as I took notes about "snatches of conversation" and "description of overall patterns of nonverbal behavior" (Erickson, 1982, p. 219). Next, I watched the interaction again and recorded notes about the content of the discussion for each minute of the video. As I watched the video for a third time, I marked each minute with the codes generated from constant comparative analysis of the interviews and any new codes based on the participants' speech. After coding the entire coaching interaction in this manner, I selected smaller segments of the video data that were multiply coded (i.e. representative of several themes) for detailed transcription. Such multiply coded chunks of data were rich sources for close analysis because they offered insight into how multiple Discourses simultaneously circulated within the local learning community. I defined the boundaries of these segments 
according to Bloome et al.'s (2005) description of a literacy event and Bamberg's (2004) similar conception of a small story.

In constructing the detailed micro transcripts, I relied on the conventions for microethnographic discourse analysis developed by Green and Wallat (1981) and Bloome et al. (2005). See Appendix B for a key of the transcription conventions. The transcriptions included both the participants' speech and contextualization cues (Bloome et al., 2005; Gumperz, 1986). Contextualization cues can include signals such as shifts in volume and tone, gestures, facial expressions, gaze, posture, and register shifts (Bloome et al., 2005; Green \& Wallat, 1981). I divided the participants' speech into message units, which are the "smallest units of conversational meaning," (Bloome et al., 2005, p. 19) and interactional units, which are "a series of conversationally tied message units" (Green \& Wallat, 1981, p. 200). I primarily identified interactional units according to topical shifts in the conversation, but I also attended to ideological shifts and participant structures when appropriate.

Taken together, these elements of social interaction aided in my analysis of how the participants were constructing meaning and positioning themselves and others within the real-time space of face-to-face coaching interactions (Bloome et al., 2005). Through such close analysis, I aimed to achieve an emic perspective (Bloome et al., 2005), which acknowledges participants' viewpoints and aids in identifying the perlocutionary effects of their discursive moves. In other words, microanalysis of literacy coach/teacher interactions assisted in understanding the ecology of the unfolding discourse (Erickson, 2004) or the co-construction of social meaning based on "the effects of the speaker's 
utterances on the listener" (Jaworski \& Coupland, 1999) in relation to the prevailing expectations and Discourses of the school's professional learning community.

\section{Phase Three}

Phase three included a three-level positioning analysis, as recommended by Bamberg \& Georgakopoulou (2008), on each of the small segments of data. These breif segments consisted of several minutes selected from the entire video-recorded event and were divided into interaction units as described above. In the first level of analysis, I attended to the narrative structure of the segment and asked what the story was about, who the characters were, and how they were positioned in relation to one another. Such attention to the narrative structure generally offered valuable insights into the purposes and intents of the participants' unfolding stories and helped to frame their discursive moves.

In the second level of analysis, I focused on what the speakers were trying to accomplish through their discursive moves and by using a particular narrative or interactional structure (Watson, 2007). During this level of analysis, I drew on a range of research tools for discourse analysis. As suggested by Bloome et al. (2005), I examined each message unit, along with contextualization cues, for the signaling and uptakes of identities, conversational functions, social significance, knowledge building, intertextuality, interdiscoursivity, and intercontextuality. I drew on Gee's (2011b) tools for discourse analysis such as examining message units and interactional units for deictics, intonation, framing, vocabulary, speaker intention, integration and cohesion. I also employed Gee's tools for examining broader issues. For example, the Identities Building Tool encourages the researcher to ask "what socially recognizable identity or 
identities the speaker is trying to enact or get others to recognize" (p. 199), and the Politics Building Tool asks "how words and grammatical devices are being used to build what counts as social goods" (p. 199). I further drew on research from the field of conversation analysis (Goffman, 1976; Jucker, 1993; Schegloff, 1982; Sacks et al., 1974) to examine particular words or phrases that the coaches and teachers used in interesting ways.

In the third level of analysis, I attempted to connect the participants' micro-level social interactions to macro-level factors such as the school culture and prominent ideologies about literacy coaching and professional learning. As Barkhuizen (2009) argued, this sort of analysis allows researchers to move "beyond the small story content and telling to consider the normative Discourses (the broader ideological context) within which the characters agentively position themselves and by which they are positioned" (p. 284). In other words, "level 3 draws together the analysis to provide an answer to the question, 'who am I vis-à-vis what society says I should be?” (Watson, 2007). To that end, I drew on the larger data set (i.e. interviews, field notes, and artifacts) to support conclusions made from analyses of the selected video segments and to connect them to common Discourses within the literacy coaches' and teachers' communities of professional learning.

\section{Trustworthiness}

As a researcher applying qualitative methods to explore and share the everyday interactions of others, I have an obligation to the participants and to the research community to provide a trustworthy representation of what I witness in the field and the data set that I generate (Merriam, 1995; Shenton, 2004). Harrison, MacGibbon, and 
Morton (2001) defined trustworthiness as "the ways we work to meet the criteria of validity, credibility, and believability of our research - as assessed by the academy, our communities, and our participants” (p. 3235). I employed several methodological procedures to establish trustworthiness, including thick description, triangulation, member checking, peer review, and reciprocity (Creswell, 2009; Glasne, 2005; Merriam, 1995).

\section{Thick Description}

Thick description (Geertz, 1973; Denzin \& Lincoln, 2000) “goes beyond the mere or bare reporting of an act (thin description), but describes and probes the intentions, motives, meanings, contexts, situations, and circumstances of action" (Denzin, 1989, p. 39). Such rich, detailed description allows the reader to vicariously experience the setting so that they may make their own conclusions about the transferability of the research (Lincoln \& Guba, 2000). Accordingly, I attended to thick description when constructing full field notes and writing up research findings. However, from a microethnographic stance, thick description is not enough to understand how understandings are coconstructed within immediate, moment-to-moment social interactions (Kamberelis \& Dimitriadis, 2005). As Bloome et al. (2005) argued, "methodologically speaking, what we are after is more than thick description; we are after thick description in motion" (p. 52). As such, thick descriptions of observations served as further contextualization for the small moments of social interaction analyzed as micro coaching events.

\section{Triangulation}

I used triangulation to establish the trustworthiness of the data and representations. Triangulation refers to the practice of using multiple methods for 
collecting and analyzing data (Creswell, 2009; Glesne, 2006). The purpose of triangulation is not just to combine different sorts of data but to relate them to each other (Glesne, 2005) in order to "build a coherent justification for themes" (Creswell, 2009, p. 191). I attended to principles of triangulation by including multiple participants and sites as well as drawing on multiple theoretical constructs and methodological traditions (Denzin, 1989; Glesne, 2006).

\section{Member Checking}

To further establish trustworthiness, I employed member checking (Creswell, 2009; Glesne, 2006; Lincoln \& Guba, 1985) in an attempt to ensure that I accurately represented the participants' ideas, views, and perspectives. Throughout the study, I shared pieces of data such as interview transcripts, emerging themes, and my analytic thoughts with the coaches and invited them to comment on the analyses and suggest changes if they disagreed. In addition, I shared the detailed microethnographic transcripts with the participants and invited them to conduct analysis of them alongside me. Neither coach was interested, however, in participating in such analysis due to time constraints.

At the conclusion of the study in the early fall of 2013, I presented findings to the coaches and asked them to provide their own interpretations, feelings and thoughts about my findings. Both coaches agreed, in general, with my interpretations of their interactions. In fact, they both seemed to think that my analyses of their in-the-moment discursive moves were somewhat obvious. For instance, Sarah agreed that she focused on best practices within the coaching interactions but felt that it was inevitable and necessary considering her position as the literacy coach. Grace also agreed with my implications 
and discussed ways that the institutional structures and her coaching practices might change.

\section{Peer Debriefing}

Peer debriefing allows for colleagues who are external to the research process to provide input, review work, and ask questions about ongoing research work (Creswell, 2009; Glesne, 2006). The practice of sharing work with peers helps to ensure that "the account will resonate with people other than the researcher" (Creswell, 2009, p. 192) and adds trustworthiness to the research project. To this end, I invited several "critical friends" (Rossman \& Rallis, 2003, p. 69) to read chapters of the dissertation in progress and to analyze microethnographic transcripts. The chair of my dissertation and other members of the committee provided valuable insights into my analyses and asked questions that required me to revisit the data, to deepen my analysis, and to improve the clarity of my writing.

\section{Reciprocity}

Reciprocity refers to the give and take between the researcher and the researched. In other words, reciprocity is "the exchange of favors and commitments, the building of a sense of mutual identification, and feeling of community" (Glazer, 1982, p. 50) between researchers and participants. Harrison et al. (2001) have argued that reciprocity is an essential element of trustworthiness in qualitative inquiry, particularly in research conducted from a feminist perspective. A feminist theoretical framework encourages researchers to address issues of hierarchy, power, and voice, to ask who is benefiting from the research, and to honor obligations to the participants (Harrison et al., 2001; Lather, 1991). In an effort to achieve reciprocity, researchers resist casting themselves 
"as an aloof outsider" (Glesne, 2006) by employing such strategies as close listening, reflecting with participants, and participating in work alongside participants (Glesne, 2006; Lather, 1991). Researchers may also engage in collaborative research by including the participants in all phases of the study and offering opportunities for collaborative authorship (Coffey \& Atkinson, 1996; Harrison et al., 2001).

Although I did not directly draw on a feminist framework for this study, I applied these precepts to my research design when considering my ethical obligations to and relationship with the participants. For instance, I attempted to achieve a level of reciprocity with the participants by being clear about benefits and obligations, sharing data, inviting coaches and teachers to analyze data and to collaborate on publications, and volunteering to participate in daily school activities and tasks. Throughout the study, I was able to achieve a certain level of reciprocity with the participants. I shared data with them on a fairly regular basis, was open with them about my ongoing findings and related emotions, and participated in some activities alongside coaches. I was not able, however, to achieve as deep a level of reciprocity as I had hoped, and my collaboration with the coaches and participation in school activities was minimal.

Strategies for reciprocity, along with the reflexive stance of microethnography, can help to uncover power relations between participants and between researchers and participants (Bloome et al., 2005). However, as Bloome et al., (2005) argued,

There is no escaping either the characterization of educational research as a social institution, with all of the grand narratives, structures, rituals and rites, language, and culture of any social institution; neither can educational researchers escape being implicated in power relations. (p. 166) 
As such, I tried to remain cognizant of these power relations even as I strived to negotiate them with my participants and to achieve a level of reciprocity.

\section{Ethical Considerations}

The importance of considering ethical issues that may arise throughout the course of a research study has been widely documented by qualitative researchers (Creswell, 2009; Glesne, 2006; Merriam, 198; Spradley, 1980). It is essential that the researcher take steps to protect the "rights, needs, values, and desires" of the participants (Creswell, 2009, p. 198). As Spradley (1980) argued, the research process is inherently obtrusive and often reveals sensitive information about the informants. Therefore, I took several steps to protect the rights of the participants. First, the study was approved by Illinois State University's Internal Review Board as well as by the administration of the two schools included in the study. Secondly, I ensured that the signed letters of informed consent clearly communicated the parameters of the study to the participants. The letters were distributed to teachers, school-based coaches, district literacy coaches, and principals and included an introduction to the purpose and scope of the study and detailed information about the procedures for data collection, transcription, analysis, and dissemination. Furthermore, the letter clearly outlined the potential risks and benefits of participation in the study and communicated the voluntary nature of their participation. Finally, the letter informed the participants of the steps that I took to ensure their confidentiality such as the use of pseudonyms and the secure storage of data.

Ethical considerations do not end with the distribution and signing of the informed consent form. Rather, unanticipated ethical issues often arise throughout the research process (Creswell, 2009). As Glesne (2006) argued, "Ethical codes certainly 
guide your behavior, but the degree to which you research is ethical depends on your continual communication and interaction with research participants throughout the study" (p. 146). Therefore, I attended closely to the issues related to trustworthiness described above and reflected about ethical issues on a weekly basis in my research journal and discussed them with participants when appropriate.

\section{Summary}

In this chapter, I outlined the research paradigms and the ethnographic and microethnographic approaches that I used in this study. I also detailed my research design, including the setting, participants, data sources, and analysis. I explored my positionalities and subjectivies as the researcher, attended to issues of trustworthiness, and addressed the ethical dimensions of research.

In the next chapter, I provide a more detailed description of the participants and the context in which the literacy coaching interactions took place, and I describe the Discourses identified through CCA in greater detail. I present the Discourses as separate categories for ease of discussion. However, it is important to note that there was a great deal of overlap and connections between and across the Discourses. Moreover, these Discourses influenced the coaching interactions in complex, simultaneous, and often conflicting ways. In an effort to communicate the interconnectedness of the Discourses and to avoid oversimplification, I often refer back to previous chapters or attempt to orient the reader to later sections of the dissertation. 


\section{CHAPTER IV}

\section{LITERACY COACHING IN THE LOCAL CONTEXT}

As outlined in chapter two, there are many models and definitions of literacy coaching that differ from school to school and district to district. Literacy coaches enact a wide array of roles, and their job descriptions are often vague and multiply interpreted (Bean et al., 2003; Dole, 2004; Deussen et al., 2007; Jones et al., 2010; Otaiba et al., 2008; Vanderburg \& Stephens, 2010; Walpole \& Blamey, 2008). As in many school districts, the participants' understandings of and expectations for literacy coaching were varied and sometimes conflicting. Coaching is a highly contextualized and political practice, and as such, its meanings and purposes were constantly negotiated within Norwood and Westfield Schools.

In this chapter, I present a broad picture of how the coaches, teachers, and administrators understood literacy coaching. First, I outline the local expectations for the literacy coaches' roles and tasks in order to provide a sense of how the coaches interacted with teachers and administrators in their daily work. In the next part of the chapter, I connect those daily practices to dominant Discourses of best practices, development, credibility, and collaboration that circulated within their learning community. I begin to illustrate how these Discourses influenced their negotiations concerning what professional development means within their schools and district and who decides. This 
overview provides a context for interpreting the in-the-moment tactical negotiations that occurred within the coaching interactions presented in chapters five and six.

\section{Local Expectations for Literacy Coaching}

Since literacy coaching was a relatively new position in the district, the coaches, teachers, and administrators were developing understandings about its purposes and how it should be enacted. Although the expectations for coaches varied between schools and from teacher to teacher, there were commonalities in how they described the coaches' work. In general, literacy coaching was seen as a means to support the successful implementation of workshop methods across the curriculum, and certain coaching tasks were universally expected.

\section{Purposes of Literacy Coaching}

The coaches, teachers, and administrators primarily talked about the purposes of coaching in terms of best practices. Sometimes they used the term best practices specifically, but more often they spoke about how the literacy coach was there to support the teachers in gaining knowledge and skills related to district-supported workshop methods. For example, when I asked Sarah what her personal definition of coaching was, she answered,

I think that a coach is a person in the building who can lift teachers' understanding about, maybe, new concepts and ideas, is there to provide professional development, maybe, around district initiatives and concepts that are new. So, helping to provide that support so that teachers can move forward in that. I think that a coach is there to ultimately move learning forward. (Interview, $5 / 21 / 13)$ 
When asked the same question, Grace answered that a coach helps teachers to find their potential. When I asked her to elaborate, she answered,

I think often times I find in my coaching role that teachers are not doing things because they don't have the knowledge. They don't know what they don't know. So, once you are able to highlight it through a resource or though an article you read or show them by modeling for them or demonstrating or allowing them to visit a colleague to see it in action, then they discover that knowledge. And pretty soon they want to know more about how to implement it themselves. (Interview, $5 / 21 / 13)$

The teachers defined literacy coaching in similar ways. For instance, Katie defined a coach as "somebody who is right alongside of you, giving you advice, giving you help, modeling for you. It can be co-teaching and co-planning, but also there to encourage you and lift your teaching to the next level" (Interview, 5/23/13). When I asked Amy about the benefits of coaching, she said, "I think it's good because I think it fosters open communication between educators to grow, to talk about things that are new, different concepts" (Interview, 12/13/12). In all of these descriptions of coaching, the coaches and teachers focused on knowledge and understanding of "new concepts," which can be understood to be the best practices supported by district initiatives. "Moving forward" or reaching "the next level" implicitly meant gaining knowledge and skill in workshop methods. This conceptualization of the purposes of literacy coaching aligned with a technical model in that it emphasized the implementation of specific practices (see chapter two). 


\section{Coaching Tasks}

Everyone recognized that the coaches performed many different roles, which were sometimes difficult to manage. As Grace shared, "coaching takes on a lot of faces" (Interview, 10/17/12). Similarly, Katie described Grace's work as follows, "She does a lot. I think she has a little bit in each pocket... She has a lot on her plate. I know she dabbles in all those areas" (Interview, 12/3/12). As such, literacy coaching included many different tasks, which were often closely associated with the implementation of workshop methods considered to be best practice within the district.

Mentoring. The district required that all first and second year teachers participate in an induction program. In previous years, other teachers were assigned to be mentors, but in the year of this study, the program changed so that literacy coaches served as mentors for all new teachers. The new teachers were required to log a set number of contact hours with their mentor and to participate in a coaching cycle in which a lesson was videotaped for analysis and reflection. Sarah met with her mentees weekly or biweekly, while Grace met with her mentees on a less regular basis, as needed. The three new teachers in this study, Tiffany and Luke at Norwood and Sophie at Westfield, expressed appreciation of the coaches' mentoring and support. For instance, Tiffany described Sarah as “a very open person...she's just warm. I feel like I can talk to her about anything and feel like she will help me to get to where I need to be" (Interview, 12/10/12). As the last portion of Tiffany's comments suggests, this mentoring was closely associated with supporting the implementation of best practices.

Modeling. Modeling was often mentioned as an important part of the coaching role. For example, Nina described a coach as someone who "comes in and demonstrates 
different things to do in the classroom" (Interview, 12/22/13). Similarly, Danielle stated that Sarah "does a lot of showing. She's come in a couple of times, and I sat and watched her work with kids" (Interview 1/8/13). Modeling was not, however, a frequent part of either coaches' work and occurred primarily in novice teachers' classrooms. It seemed to be a coaching task that everyone thought coaches should do, but one that did not occur regularly because teachers were somewhat reluctant to invite the coaches into their classrooms. Grace described Katie's reluctance as such, 'I've never done a coaching cycle in her four walls side-by-side with her because she hasn't invited me in to that level. I think it's a little of that intimidation because she's focused on pleasing me and what I think about her" (Interview, 5/21/13). This reluctance was partly based in the teachers' fears of looking foolish or failing to properly implement workshop methods.

Observation and feedback. Similar to modeling, the coaches, teachers and administrators mentioned observation and feedback, or "the coaching cycle," as part of an ideal definition of coaching, but it rarely occurred. Coaching cycles were a required part of the induction program for new teachers, but other than that, it was usually something that was going to happen in the future. For instance, Sarah's principal, Larry talked as follows about coaching cycles in our first interview when he explained Sarah's work as a literacy coach.

She hasn't done a real long term coaching cycle yet. She's getting ready to work on one of those. I've talked with her about a teacher that I think would really benefit from a longer-term coaching cycle. I've also encouraged the teacher to seek that out. I think that's my role in helping Sarah be able to do those long-term coaching cycles is to say to the teacher, 'Hey, you really need to focus in on some 
improvement in this area and a really good resource for you is Sarah. (Interview, $10 / 24 / 12)$

That coaching cycle, like most of the plans for coaching cycles, never happened. The formalized cycles were something the coaches thought they should do but felt uncomfortable implementing because the teachers lacked trust or did not value such work. For instance, when I asked Sarah if all teachers should participate in coaching, she explained,

It depends on the role of the coach in the district in which they work and the school in which they work. It's how they're perceived...If there's not that understanding of what a coach can do with teachers...then it might not be a fullblown coaching cycle, but it's at least talking about planning and thinking about the environment. (Interview, 5/21/13)

This quote highlights that the coaching cycle of observation and feedback is a desired outcome, an example of "full-blown" coaching, but is not always achievable due to contextual constraints.

Resources. Both of the coaches considered providing resources to be a major part of their role, especially Grace. She explained, "Resources is certainly one of those ways to coach...I'll bring them resources or examples or something like that because that was a topic that they were wanting" (Interview, 10/17/12). When I asked Sarah what she meant by supporting teachers, she answered, "I've tried to be supportive in being able to find resources and help them go through those resources and talk through how they can use those in their classroom" (Interview, 5/23/13). The coaches saw providing resources as a non-threatening way to provide information and support to teachers. As Grace explained, 
"You can relate to them because you have resources. I try really hard to keep coaching meetings content focused, something applicable to them that they can walk back tomorrow and use" (Interview, 10/17/12).

The teachers appreciated the resources that the coaches provided. When I asked Nina what the benefits of having a coach were, she answered,

Just the resources...All this kind of stuff that she gives us. I don't have time to do that, and I don't even know where to even get all this stuff. And the resources that she gives us for us to be successful in our intervention group. I think that's probably her biggest strength. (Interview, 12/5/12)

When I asked Tiffany what Sarah does at their special education department meetings, she answered, "She gives us different resources, and we looked, the last time, at different questions to ask, and so she had a whole list of nonfiction questions that you can ask students to prompt the student, which was really helpful" (Interview, 12/10/12). Danielle shared, "Sarah has been a really good resource for me to go to just for, you know, help (Interview, 1/8/13). At Westfield School, Katie explained that Grace helped her to access more useful and meaningful resources than the ones that she had been using in the past (Interview, 12/3/12), and Sophie said, "The resources that we get from Grace are really helpful" (Interview, 4/25/13).

The principals saw the coaches themselves as resources. Larry described Sarah as such, saying, "She's not simply a resource allocator or grabber or whatever, she is a resource herself and can provide them with information and things to guide their path, which is a very powerful role" (Interview, 10/24/12). Donna, the principal at Westfield, explained how Grace was a resource for her own administrative work. She shared, "I 
can't do it all. If I didn't have Grace, life here would be different...she'll do a lot of the groundwork for me" (Interview, 10/24/12). Regardless of whether the resources were human or material, the assumed purpose was to support the implementation of particular workshop methods.

Conversation. The coaches explained that much of their work was done subtly through conversations with teachers as opposed to more formalized coaching cycles in teachers' classrooms. Sometimes these conversations were formal, scheduled, mandatory meetings such as departmental or grade level meetings. They saw these meetings as an opportunity to listen to teachers in order to understand their needs and to gain access to classrooms. When I asked Sarah how she decided which teachers to work with, she explained, "I've been trying really hard to follow up on things I've asked about, which has led to other conversations. So, I think just getting out there and trying to be a part of their conversations in meetings. I think that's helped" (Interview, 10/24/12). Similarly, when I asked Grace about her relationships with teachers, she replied, "The more work I do with them and the more conversations I have with them, the closer I am with them" (Interview, 10/17/12). She went on to explain,

Unfortunately, with some people it's hard to start that first ball, you know. Like if they don't want to converse with you that first time. So I do think the coaching meetings help a lot with that because then it's just in conversation in a group I'll hear something, and then I'll want to follow up on that. Like after that meeting like, 'Well, I heard you talking about this, could we work together?' So that kind of opens some doors without them initiating it really. (Interview, 10/17/12) 
Other times, these conversations occurred in passing with individual teachers. The teachers often talked about how such conversations with coaches helped them. For example, Tiffany said that she and Sarah "talk about everything. We talk about how things are going in here, particular students. We talk about interventions" (Interview, 12/10/12). Danielle shared how she has "popped in" to Sarah's office "six or seven times" and asked her to help her problem solve or share ideas (Interview, 1/8/13). At Westfield School, Katie credited her professional growth to her "informal conversations" with Grace. She said, "I think the conversations that we had reaffirmed some of my thoughts I already had about conferring, and it motivated me to do it" (Interview, 5/23/13). These comments speak to the complexities of gaining access to teachers and classrooms.

Providing professional development. The coaches also lead professional development activities such as presentations at meetings, book studies, video discussions, and curriculum planning. The coaches were often involved in planning and leading professional development during school-wide improvement days (SWIP), which were regularly scheduled teacher institute days during the school day. Sarah listed SWIP days as one of the ways she gained credibility with teachers at the beginning of the year. She said, "Larry has already had me lead out professional development at two of the SWIP days" (Interview, 10/24/12). Coaches also lead professional development activities for small groups in department or grade level meetings. As Larry explained, "We have departments meet once a week together. That's a time where she can facilitate some targeted professional development” (Interview, 10/24/12). These sorts of PD activities helped to cement the coaches' reputations as expert leaders because they had been 
provided by administrators and administrators in the past. As such, these activities lent the coaches an air of authority.

Data management. Both coaches were involved in the management and interpretation of student data but at different levels. Larry did not want Sarah's job to be overwhelmed with that role. As Sarah shared, "I'm part of the data meetings, although he [Larry] does not want data to encompass everything that I do...He'd rather see me with teachers" (Interview, 10/24/12). Data management, on the other hand, was a major part of Grace's role. Every Friday morning, she led the problem solving meetings to review data and plan interventions, and she managed the school's input into the district's computerized data management system. Her principal, Donna, considered this work to be a key piece of Grace's instructional leadership and credibility. As she said,

She leads out these Friday morning meetings, which are for problem solving around data, and that's a very important part for me...I think we have the success that we have because she has been able to take that leadership position, and they value her expertise. And I think if I was more of the director she wouldn't have that reputation, and she wouldn't have the relationships. (Interview, 10/24/12)

Interventions. The coaches were considered experts in providing reading and writing interventions for students. Specifically, they were experts in interventions associated with the Comprehensive Intervention Model (CIM), which consisted of comprehension focus groups for the middle level and guided reading plus groups for the elementary level. Both Sarah and Grace coached other interventionists in the proper implementation of the CIM frameworks for intervention. Grace acted as an 
interventionist herself and taught several small groups of students each week. Sarah, on the other hand, did not work directly with students in that capacity. As she explained, I don't have my own intervention group... Larry sees my role more as that support person for intervention, and that I can help move those interventions along and make the interventionists better as opposed to just having a small group of kids. (Interview, 10/24/12).

In both cases, there was a heavy emphasis on particular procedures for interventions and an expectation that coaches were more expert in those procedures than the teachers.

\section{Discussion of Dominant Discourses within the Coaches' Work}

Understandings of literacy coaching and its purposes are dependent on much more than simply what coaches $d o$. The coaches' work was situated within the existing structures of their district and schools, local norms of collaboration, personal relationships, and broader dominant Discourses concerning teacher development and best practices, as described in chapter two. These Discourses served as sites for negotiating issues of power, positioning, and identity, and this negotiation was an emotional process occurring across and in relation to institutional spaces and times.

\section{Best Practices}

Everyone that I interviewed frequently described workshop methods and procedures as the most effective instructional practices and/or recognized them as the prominent district initiative. They often mentioned "training" that they received in workshop methods. Sometimes these trainings were provided by outside experts associated with the Partnerships in Comprehensive Literacy model or with the Teachers 
College writing workshop model. Other times they were provided by district literacy facilitators or school-based coaches in either mandatory sessions during work hours or voluntary workshops after school and in the summer.

This focus on training in a particular method aligned with the Discourse of best practices, which recognizes “evidence-based" practices over teachers' contextual understandings and professional inquiry (Britzman, 2003; Dewey, 1933; Webster, 2009). Within the Discourse of best practices it is assumed "that knowledge related to teaching is universal and generalizable and that the teacher's job is to know that knowledge and apply it with fidelity" (p. 675). As Shannon (2001) explained, all teachers are consumers of products claiming to be best practice, evidence-based, research-based, or scientifically-based. This becomes a problem, however, when teachers are expected to consume best practices without question (Davies, 2003) and when methods replace teachers' professional judgment as the driving force of instruction (Gee, 2011a; Shannon, 2004). Within a Discourse of best practices, "We [as educators] are told that others know better about our work and how to do it, and our lives and how to live them" and "by design and/or default, then, teachers' choices are limited"' (Shannon, 2004, p. 24).

Valued local practices. In this district, workshop methods were considered to be best practice. As Danielle shared, "All of us are working on the workshop, and we just need a little bit more help with how to do it and how to get better at it" (Interview, 1/8/13). The coaches often described the purpose of coaching as sharing knowledge of and encouraging implementation of specific workshop techniques. For instance, Grace considered her main role to be "helping them [teachers] to define and hone in on their own craft and techniques that they're using with their students" (Interview, 5/2/1/13). 
Furthermore, particular ways of doing workshop were considered to be the "real" workshop model. As Katie shared, “Grace's role has been a very important part of my learning with the workshop approach, because before she came, I thought I was doing workshop" (Katie, Interview, 5/23/13). At the junior high level, workshop meant the implementation of mini-lessons, modeling skills, conferring with students on their independent work, student journals, and purposeful observation of students. At the elementary level, workshop meant a mini-lesson followed by independent work time during which the teacher conferred with students or worked with small groups followed by share time. The use of student journals was also a requirement. Any deviation from these practices was considered a failure to implement workshop. For example, Grace complained about teachers who used centers during reading workshop or who had a separate independent reading time (Interviews, 4/25/13 and 5/21/13).

The correct implementation of workshop was defined according to outside experts' models of reading and writing workshop and literacy intervention. Specifically, the district relied on consultation from Teachers College on the Units of Study for Writing (Calkins, 2006) and the Partnerships of Comprehensive Literacy's model for school-wide literacy reform, which included reading, writing, and content-area workshops and frameworks for interventions including comprehension focus groups and guided reading plus. As Donna explained, "We have Linda Dorn and all that basis of the workshop, and we have Lucy Calkins with the writing...These, more or less, are mandates" (Interview, $10 / 24 / 12)$.

Best practices as a de facto mission and vision. To be clear, I am not suggesting that workshop methods are ineffective or undesirable. In fact, I used workshop methods 
in my own second grade classroom, including Calkins (2006) Units of Study for Writing, for years. Instructional methods associated with reading and writing workshop hold much promise for quality literacy instruction, and are considered by many literacy researchers and educators to be highly effective practices (Fountas \& Pinnell, 2001; Graves, 1983; Reutzel \& Cooter, 1991; Serafini, 2001; Whitmore, Martens Goodman, \& Owacki, 2005). I am, however, critical of the best practices Discourse because specific techniques are presented as infallibly true, and teacher knowledge and professional judgment are discounted. Within such a view, the implementation of best practices replaces a shared mission and vision for students' learning as the ultimate goal of professional learning and collaboration.

Indeed, the coaches, teachers, and administrators most often spoke in terms of implementing best practices rather than in terms of a broader vision for student learning. For example, Donna, the principal at Norwood, explained her vision for Westfield School in terms of the districts' initiatives for reading and writing workshop implementation. When I asked her about her mission and vision for the school, she shared,

A lot of the vision that I have for the school has always been tied in to the vision of the district. When you get down to the meat of it, what we're doing in the building has been, the past few years, the language arts focus with the workshop. (Interview, 5/9/13)

When I asked Grace what professional development means, she answered that it is "any resources or techniques that allow you to move forward towards that mission or vision or goal." When I asked her what her vision was, she replied, "To provide differentiation for students and right now that's approached through the workshop model 
because that's the best practice that we know" (Interview, 5/21/13). Similarly, Sarah said, "When I say best practice, I think of reaching all the students in the classroom and thinking about their needs, and so for me it's differentiation" (Interview, 5/21/13). In this sense, best practices were viewed as tools to meet an end goal; however, they were considered to be the only tools for reaching the goal of differentiation. Teachers did not speak to the goal of differentiation, but focused solely on the implementation of workshop methods, doing what they should do, or developing a greater knowledge of best practices.

Counter Discourses. Although the Discourse of best practice was dominant within these two schools, counter Discourses circulated as well. For instance, the coaches sometimes acknowledged the value of teachers' contextualized understandings. When asked to define best practices, Grace shared,

I think best practices are always changing, and I think best practices really often times look a little different in every teacher's classroom. The reason, I think, is the knowledge of the students, the knowledge of the teacher. I think both of those aspects play hugely into the implementation of any technique or any practice. I do think best practices are research based, usually have some evidence behind them as to what's been tried with them before and the proven effectiveness of them. (Interview, 5/12/13)

When explaining her philosophy of coaching, Sarah said,

I don't ever want teachers to come and sit and get and take away information from me. It has to be that they're the ones that are learning it and actively engaged in what they're doing. And so if we sit down to discuss something, I think that we 
have to go try it. We have to be a part of figuring out what works and what doesn't, being reflective about that. (Interview, 5/21/13)

Although there was a heavy emphasis on particular workshop methods, the teachers felt that they had some degree of freedom with how they implemented them. As Katie shared, "Grace came and she was very good at leading us to the water but not really saying, 'No. This is how it works" (Interview, 12/3/2). Similarly, Luke said,

Sarah is not that type where she would be, 'Hey, I really think you should do this.' I feel like I have freedom, because I feel like, not to throw anyone under the bus or anything, but I don't think any social studies teacher here probably does it $100 \%$ either. I mean, we all teach differently. (Interview, 5/16/13)

These quotes from coaches and teachers highlight the complicated ways that conflicting Discourses about best practices were negotiated. The coaches acknowledged that teachers have contextualized knowledge and expertise that they use to interpret best practices. The teachers indicated that they have and appreciate freedom regarding if and how they implement best practices. Nevertheless, it is clear within these quotes that a particular model of teaching was the ideal. These conflicting Discourses were prevalent in the coaches' conversations with teachers as they negotiated tensions concerning what counts as relevant knowledge for making instructional decisions, and I highlight these tensions in more detail in chapters five and six.

\section{Development}

Notions of development were evident in the participants' discussions of novice versus veteran teachers and the need for support and training. Their ideas about 
professional development and their ideas about development in a more general sense affected their views of and participation in literacy coaching.

Professional development and best practices. The primary purpose of professional development (PD), often referred to as training in the local context, was to increase teachers' knowledge and implementation of best practices. Moreover, PD was most often discussed in terms of activities, as something done to teachers, rather than as a mutual exploration or inquiry. When I first asked Sarah to define PD, she listed out activities such as professional book studies, grade level meetings, and workshops. She said, "I think being part of grade level meetings and planning activities, that type of thing, would be professional development to me: moving the craft forward, best practice" (Interview, 5/21/13). When I asked her about the purposes of such activities, she further focused on best practices, saying, "Sometimes we have to grow in our profession and keep up on new practices and new research and knowing what's out there that does help with student growth" (Interview, 5/21/13). Grace also thought of PD as a way to increase knowledge of best practices, and said, "I think, for me, that my PD, my coaching helps others to gain the knowledge they don't know" (Interview, 5/21/13).

Within such a view of PD, the teachers' learning was seen as a linear process of knowledge transmission. The end goal for all teachers was to appropriately implement workshop methods as defined by the coaches and by outside experts. This view limits alternative ways of knowing, doing, and being and inhibits innovation, or as Engeström (1996) described it, "breaking away" (p. 126) into something new and unexpected. As such, the Discourse of development as best practices constrained the coaches and teachers and set their course of development along an inflexible and predetermined path. 
Stage model of teacher development. The literacy coaches, teachers, and administrators frequently drew upon a stage model of teacher development when describing the purposes of coaching. Research in continuing professional development has highlighted problems with this stage model such as the assumption of uniform, stepwise progression, an over emphasis on experience, and the obfuscation of the complexities and uncertainties inherent in professional learning (Britzman, 2003; Dall' Alba \& Sandberg, 2006; Day \& Gu, 2010; Edwards \& Nicoll, 2006; Grossman, 1992). Britzman (2003) argued that the linear stage model of novice and expert teachers normalizes the status quo and prevents the exploration of how teachers learn and come to value certain forms of knowledge and practice. Although she studied student teachers, her insights in this regard are applicable to the first and second year teachers in this study. She argued,

Many student teachers and the professionals who surround them, then, approach the problem of knowing not as an intellectual, emotional, and esthetic challenge, but as a function of accumulating classroom experience. The theory of knowledge asserted here depends upon stasis; knowledge is understood as unencumbered by values, interests, and ideology, and is handled as if it were transcendent. (p. 229) This static view of teacher development was reflected in the participants' comments about who the literacy coaches worked with and why. The coaches worked with novice teachers more often than veteran teachers because they were seen as in greater need due to their lack of experience. For example, Nina explained that "We have two new Special Ed teachers who know nothing about the CIM" (Interview, 12/5/12), so it was important for Sarah to coach them in the frameworks for interventions. Veteran 
teachers were viewed as needing assistance from the coaches if they were trying "something new for them" (Sarah, Interview, 10/24/12). Grace explained that teachers ask her for help when they are "unsure' or "don't know the curriculum or content." She said that teachers often tell her, "I need more help with this, or this is something I haven't tried. I don't have a lot of ideas" (Interview, 10/17/12). Within this stage model, teacher development was seen as a finite and linear process with a universal end goal rather than as sustained professional learning or shared inquiry.

Sociocultural cognitive development. Ideas related to strongly held beliefs about sociocultural cognitive development positioned coaches as authoritative experts and teachers as deficient and in need of help. As highlighted in many of the above quotes, the coaches were considered the experts in literacy and workshop methods and were expected to possess knowledge that the teachers did not. This view of the coaches' expertise aligned with the Vygotskian notion of "the more knowledgeable other" in which "a teacher or peer is more capable than another individual, the learner" (Roth \& Radford, 2009, p. 299).

Within a sociocultural cognitive view of development, the more knowledgeable other provides scaffolding (Wood et al., 1976) within the learner's zone of proximal development (Vygotsky, 1978). Although there is great potential for learning within this theoretical construct, it is often simplistically interpreted to mean that the learner is deficient and needs to move to an improved level of knowledge and understanding (Engeström, 1996; Matusov \& Hayes, 2000; Roth \& Radford, 2009). This view of the learner was evident when coaches and administrators talked about "lifting" teachers thinking, moving them "forward" to "the next level." Sarah described the first and second 
year teachers that she mentored in these terms saying, "They know that I'm there to help support and lift them" (Interview, 5/21/13). Grace evaluated the teachers in her building as "at very, very different levels of implementation now" (Interview, 10/17/12). In a similar vein, Larry described one of the social studies teachers with whom Sarah was working as follows,

He's feeling like he's not doing things as well as he could be. And, he's kind of backslid a little bit so she's going to go in with him and just kind of lift him back up and get him back on target with just some key things that he's not doing that he had done in the past. (Interview, 10/24/12)

Within this Discourse of vertical development across levels, the teachers were characterized as in need of help, and the coaches were characterized as "nurturing" (Donna, Interview, 10/24/12) providers of support. The coaches and teachers used the word "help" repeatedly as they explained how coaches supported them in developing "better understandings" (Tiffany, Interview, 12/10/12; Katie, Interview, 12/13/12). Tiffany shared about Sarah, "She will help me to get to where I need to be" (Tiffany, 12/10/12). Danielle described Sarah in a similar way when she said, "She's helped me a ton this year with comprehension focus groups and also knowing a little bit more about the workshop approach and conferencing (Interview, 1/8/13). When I asked Amy about the benefits and drawbacks of coaching, she explained how Sarah goes into classrooms "for teachers that are struggling" and that puts teachers in a vulnerable position. She shared, "I think acknowledging the fact that you do need help in certain areas, in the areas that you want to improve upon, you have to be willing to do that in the first place, be open to being humble" (Amy, Interview, 12/13/12). 


\section{Credibility}

The coaches and administrators brought up credibility when I asked about the coaches relationships with teachers. They used the term credibility without prompting and considered it to be an essential part of effective literacy coaching. The principals, in particular, emphasized that the success of coaching depends on having "a coach that has that credibility" (Donna, Interview, 10/24/12). As Larry said about Sarah, "She gives them good solid advice that when they take it, it helps them, and that builds that street cred idea of 'Hey, this person actually does know what the heck they're talking about.' That's important" (Interview, 10/24/12). Coaches established this credibility by demonstrating expertise and by developing trusting relationships with teachers.

Expertise. The coaches developed credibility through demonstrating expertise in workshop methods and knowledge of literacy development and instruction. Both principals and teachers expressed a great deal of trust in the literacy coaches' expertise. Tiffany, a first-year teacher, described her trust in Sarah's expertise, saying, "I know that she is a really experienced teacher and that she has a lot of training, so I know that she can be very helpful to me and how I'm growing as a teacher (Interview, 12/1012). Veteran teachers at Norwood thought Sarah was more credible than the previous coach. For instance, Danielle stated, "More people are more comfortable with how knowledgeable she is versus the person who was in that position last year" (Interview, 1/8/13). Grace was equally respected for her knowledge of workshop methods. As Katie shared, "It didn't take me long to trust her and realize how much knowledge she did have and how much knowledge I didn't have" (Interview 12/3/12). Donna said that Grace's credibility came from the fact that "she has taught workshop" and "she's the expert." She 
added that Grace "has years and years of training" (Interview, 10/24/12). The coaches talked about teachers' trust in their expertise as a justification for their work and evidence of their success as coaches. For example, Grace shared, "I think I became a very respected person in the building as far as knowledge and resources" (Interview 10/17/12).

Trust. The coaches and principals rarely mentioned relational trust, but it was an important part of the coaching interactions from the teachers' perspectives. They trusted that the coaches would not judge them or challenge their intelligence and competence. As Danielle shared about Sarah, "She's friendly and kind and does not make me feel stupid" (Interview, 1/8/13). Similarly, Katie said about Grace,

She doesn't judge you, whether she does it behind your back or whatever in her head, but she never shows that. That's what I liked about it [coaching]. She's not going to make fun of me for what I don't know. I just don't know. It's not my fault that I don't know. But now I want to do everything. Like, 'I want to be you, Grace.' She's like the guru. (Interview, 12/3/12)

This trust seemed to be at least partly based in the expectation that the coaches would not push the teachers into discomfort. Both principals described the coaches "subtlety" in leading teachers towards the implementation of workshop. Larry stated that the previous coach at Norwood "tended to be a little bit more bossy, and Sarah is just more subtle... She's not a bossy person. She's more responsive and can take things in a direction if need be but doesn't really push super hard" (Interview, 10/24/12). Donna also called Westfield's previous coach "more of a boss" and explained that Grace takes more of a "back door approach." She said, "Rather than hit them on the head and saying, "This 
is what you're going to do. This is what we're doing next,' she would just do it subtly" (Interview, 10/24/12).

\section{Collaboration}

Collaboration was expected, and both principals spoke of the importance of scheduling time for and otherwise supporting collaboration between teachers and between coaches and teachers. Collaboration was scheduled and mandated in the form of weekly department meetings at Norwood and grade level meetings twice a month at Westfield. In addition, both schools had regularly scheduled problem solving meetings during which administrators, teachers, coaches, and district special education leaders collaborated to plan interventions for students.

Within these collaborative meetings, the principals expected the coaches to "guide teachers in a direction" (Larry, Interview, 10/24/12) that lead them towards greater understanding and implementation of workshop methods and to keep them on task. As Larry stated, “They're collaborating quite well, and she's able to keep that going because if they get stuck they can seek her out as a resource. And she's providing them with information and guiding them in directions" (Larry, Interview, 10/24/12). They considered collaboration to be the most valuable when it helped the teachers to align with district initiatives. For example, Donna explained collaboration as a sort of coach-led peer pressure to implement workshop when she said,

I always kept it in the forefront that these are initiatives that aren't going away. These are not options, you know. We have three years to learn the workshop...So, Grace was able to take the comfort zones of where they were...And again, there was a little peer, I can't call it peer pressure, it was peer collaboration, that some 
were ahead of others, but working together in a nonthreatening way. And Grace is adept at that. She never makes them feel like, you know, that you have to do this. (Donna, Interview, 10/24/12)

Outside of these mandatory, pre-scheduled meeting, collaborative planning and teaching was infrequent and occurred mostly between like-minded teachers. Despite official steps towards collaboration, teachers largely remained isolated in their classrooms. Grace used the metaphor of an island to describe teachers' isolation. She said that some grade levels at Westfield collaborated "when they come to the table" but not on their own. She described other grade levels as non-collaborative with each teacher "like an island" (Interviews, 10/17/12 and 4/25/13). Katie spoke of this isolation when she described how it was difficult to collaborate with another second grade teacher who held different teaching philosophies than her and implemented workshop differently. She shared,

For the last six years, we just have very different philosophies, very different, and so I just pretend to go along, and then I go to my room, and I do my own thing, and she goes to her room and does her own thing. (Interview, 5/23/13)

Collaboration also occurred at an informal, unscheduled level throughout the course of teachers' and coaches' daily work. The teachers characterized such collaboration as more directly relevant to their classrooms. It did not always correspond with workshop methods but rather involved specifics of classroom schedules and discussion of students' academic and behavioral issues. For instance, Tiffany described the daily collaboration that she did with members of her grade level team. She said that they meet several times a week on their own "about anything." She continued, "We talk 
about team procedures... We talk about if we are having issues with one particular student" (Interview, 12/10/12). In sum, the coaches and teachers had many opportunities for collaboration, but they often interacted within these collaborative spaces at a surface level without coming to a consensus about their goals for PD and student learning.

\section{Summary}

Understandings about the purposes and expectations for literacy coaching were fairly consistent across the participants and across schools. However, they differed according to such factors as individual teachers' comfort levels with the coaches and the specific coaching tasks performed. For instance, coaching tasks such as modeling and providing resources aligned with a technical model of coaching in that they primarily supported the implementation of best practices. At times, the coaches and administrators strived to implement formal literacy coaching through coaching cycles of observation and feedback, but the teachers seemed to be largely uncomfortable with such practices. The coaches were more successful at gaining access to teachers and classrooms when they engaged in activities that aligned with an informal model of coaching such as talking with teachers in passing and providing resources. Overall, the literacy coaches were viewed as valuable resources who could support the implementation of writing workshop. However, teachers and administrators felt that it was important for literacy coaches to work in subtle ways and avoid pushing their ideas too forcefully.

These views were connected to Discourses of best practices and development that are dominant within the larger educational community and were both reproduced and resisted within the local context of this study. As such, the Discourses discussed in this chapter circulated throughout the coaches' interactions with teachers. In the following 
microanalyses of coaching interactions, I highlight how the coaches and teachers negotiated complex issues concerning what counts as knowledge, what professional learning and development mean, and who gets to make such decisions. 


\section{CHAPTER V}

\section{COACHING INTERACTIONS AT NORWOOD MIDDLE SCHOOL}

Sarah was a well-respected leader in the district and in the school. Although it was her first year at Norwood Middle School, she had already gained a great deal of respect from the principal and teachers. Her credibility was partially based on her knowledge of best practices. For instance, Amy explained that Sarah "knows her stuff" because she is the one who "presents at the conference, so she's going to follow it to the tee like it should be done" (Interview, 12/13/12). Teachers also spoke about their respect for her many years of teaching experience in which she taught "sixth grade for a long time" (Interview, 12/5/12, Nina). They expressed strong appreciation of her personal qualities such as availability, resourcefulness, openness, and friendliness. Tiffany explained, "She's a great listener to where she knows a lot about me and how I teach... and she just has a way of talking to me where I don't feel like totally inferior" (Interview, 12/10/12). Similarly, Danielle shared, “She's knowledgeable, but she doesn't make me feel stupid when I'm asking these questions" (Interview 1/8/13). As Nina summed up, Sarah is "just very easy to talk to, very friendly, just a good person" (Interview, 12/5/12).

Sarah's daily work involved a variety of tasks and could be seen as aligned with several of the coaching models outlined in chapter two. The majority of her one-on-one work with teachers consisted of working with teachers in the mentoring program. Such 
work aligned with a technical model of coaching because the district's mentoring program included cycles of pre-observation, observation, and feedback as outlined by Joyce and Showers (1980). Her work also aligned with the technical model of coaching in that she focused on specific instructional techniques associated with the workshop model including conferring, modeling, journaling, mini lessons, and the like. The rest of her work aligned more with an informal coaching model in that she maintained a flexible schedule in order to respond to requests for her support. This informal work often included attending weekly departmental meetings, co-teaching in classrooms, and facilitating book studies. More formal aspects of her work included providing professional development at school-wide improvement meetings and district institutes.

It was important to Sarah that the teachers viewed her as a collaborative equal and as one of them. She said, "I want the teachers to see me still as a teacher, and I don't want to get that far removed [from the classroom]" (Interview, 4/9/13). This spirit of collaboration was supported by the principal, who explained that he had been encouraging more collaboration over the past three years by setting aside time for weekly department meetings and by encouraging teachers to work with the literacy coach (Interview, 10/24/12). Teachers consistently spoke of their commitment to collaboration as well. Yet, in the following interactions it is evident that Discourses of best practices and teacher development limited their collaborative discussions. However, it is also clear that Sarah and the teachers navigated these limiting Discourses in unique and surprising ways, poaching in the cracks (de Certeau, 1984) of institutional structures. 


\section{Special Education Team Meeting}

The special education team consisted of five teachers, four of whom participated in this study: Nina, Danielle, Amy, and Tiffany. Nina taught language arts and social studies. Danielle taught all subjects, Amy taught math, and Tiffany taught language arts. All four teachers provided reading and writing instruction during a daily intervention block. At the beginning of the year, the principal instructed each team to collectively choose a professional development goal from a list of three choices: conferring with students, conducting purposeful observations, and implementing student journals. $\mathrm{He}$ offered these three choices because of their status within the district as best practices associated with the workshop model (Interview, 10/24/12). The special education team chose to focus on conferring with students. They were primarily concerned with improving documentation of their conferences. For example, Danielle said, "I don't know what to write down afterwards and how to document what occurred during the conference, and Sarah helps with that" (Interview, 1/8/13). Similarly, Nina argued that conferring was not a new practice since she talks to her students one-on-one all the time but expressed concern about how to document her conversations. She shared, "We have done that [conferring] for years as Special Ed teachers. We confer all the time... Now, you [the district] tell us how you want us to confer with a student and keep track of it and write everything down because that's what we have to do now. We have to confer. We have to write things down" (Interview, 12/5/12).

The teachers participated in a variety of professional development activities about conferring. Each teacher worked one-on-one with Sarah in some capacity. Tiffany was a first year teacher, and Sarah spent a significant amount of time modeling and observing 
conferences in her classroom as part of the requirements for the mentoring program. Since it was Amy's first year in the district, Sarah spent the first intervention cycle coteaching with her so that she could learn how to conduct comprehension focus groups. During that time, they spent a large amount of time conferring with students together. Danielle and Nina each invited Sarah into their classrooms at least once during the fall semester to observe and model reading conferences. Additionally, Sarah attended several of the team's weekly department meetings to deliver professional development about conferring. This professional development varied week to week based on their requests and Sarah's perceptions of their needs. It included such activities as leading a book or article discussion, sharing resources, explaining workshop procedures, and showing videos. The ten-minute coaching event discussed below (see Appendix C for full transcript) was taken from one of these professional development meetings in January of 2013.

The meeting occurred at the beginning of the school day and lasted for approximately one hour. During the meeting, Sarah presented three videos about conferring: one published video of a reading conference (Calkins, 2006) and two selfmade videos of Sarah conferring with students about a science project about simple machines. The selected coaching event consists of an approximately twelve minute discussion that occurred after they watched the first video. The coaching event can be broken down into six sub-events based on the content and flow of the discussion (Table 5.1). 


\begin{tabular}{|c|l|}
\hline \multicolumn{2}{|l|}{ Table 5.1 } \\
Sub-events within the Special Education Meeting \\
\hline $\begin{array}{c}\text { Sub- } \\
\text { Event }\end{array}$ & \multicolumn{1}{|c|}{ Content } \\
\hline 1 & $\begin{array}{l}\text { Interaction with Tiffany and Danielle about Modeling in Reading } \\
\text { Conferences }\end{array}$ \\
\hline 2 & $\begin{array}{l}\text { Interaction with Danielle about Language Use in Conferences and } \\
\text { Conferencing in Content Areas }\end{array}$ \\
\hline 3 & Nina's small story about conferring as accountability * \\
\hline 4 & $\begin{array}{l}\text { Explanation to group about teacher vs. student talk time during conferring } \\
\text { Strategies }\end{array}$ \\
\hline 6 & $\begin{array}{l}\text { Teachers ask for localized and relevant opportunities for observing teachers } \\
\text { confer with students * }\end{array}$ \\
\hline Note. * indicates that the sub-event was selected for close microanalysis. \\
\hline
\end{tabular}

Throughout the six sub-events, the over arching pattern is an Initiation-ResponseFeedback (IRF) discourse (Cazden, 1988) in which Sarah is positioned as the instructor and the teachers are positioned as students. Within this discursive pattern, Sarah is the primary discursive pivot (Goffman, 1981; Leander, 2002) in that the turns of talk and patterns of gaze revolve around and are managed by her. She initiates the discussion by asking teachers what they noticed about the video. While this seems like an open-ended question, Sarah clearly has certain points that she would like the teachers to notice. Namely, she wants them to understand the appropriate structure and purpose of conferences, to focus on strategy instruction, and to consider the amount of teacher talk time. When teachers stray from this unstated agenda, Sarah refocuses them through feedback in the form of lengthy explanations (as in sub-event 1 in IU2, sub-event 2 in IU3; sub-event 3 in IU6, sub-event 4, and sub-event 5 in IU2). Sarah is further positioned as the leader of the group because the teachers primarily direct their gaze at her when speaking. She has much longer, uninterrupted turns of talk then the teachers. 
Furthermore, the interaction rarely takes the form of a group conversation. Instead, each teacher takes their turn conversing with Sarah who is ultimately in charge of the flow and content of the discussion. Throughout the entire coaching event, she often takes up an explanatory stance (indicated by tone, gesture, and gaze), which aligns with an orientation towards professional development as knowledge transfer. The teachers, as evidenced by gazes and the participation framework, accept her position as the expert with the power to explain and give directions.

Sarah appears to have a particular notion of what effective conferences look like based on her conceptions of best practices. This is most evident in sub-event 2 when Sarah discusses the "architecture of a conference" (line 10). She is referring to Lucy Calkin's (2006) explanation of writing conferences in The Conferring Handbook, which is part of the Units of Study in Writing. This set of guide books is a highly valued source among many coaches and teachers in the learning community because the district has modeled their writing workshop based on Calkin's work and have hired consultants from Teachers College to provide professional development in writing for the past several years. The architecture refers to the "predictable structure" (Calkins, 2006, p. iv) of a conference that consists of the following components: research to understand what the student understands and is trying to do, decide how and what to teach the student, teach the student a writing strategy, link the teaching point to future writing practice.

In this sub-event, Danielle seems to be suggesting that the video they have just watched differs from the architecture in some way when she says, "I could use this more in my science and social studies, that type of a conference" (lines 31-35). In response, Sarah argues that the video did match the standard architecture of a conference arguing, 
"so she really covered, you know, everything in there" (lines 58-61). Similarly, in subevent three, Nina argues that there is a "touch base" type of conference (lines 47 and 52), and Sarah redirects her to think about "this type of conference" (line 65) that was shown in the video and focused on strategy instruction. The teachers appear to be suggesting alternatives to the architecture based on their classroom knowledge and experience while Sarah reasserts the structure and purpose of conferences as outlined by outside experts. The following two microanalyses of sub-events 3 and 6 further illustrate this negotiation of what counts as the most valuable source of knowledge and what constitutes best practices when conferring with students.

\section{Nina's Small Story}

In this sub-event (See Table 5.2 for transcript), Nina tells a small story about how she and a co-teacher, Luke, have implemented conferences in language arts. She tells the story in response to Sarah's question to the group in line 1, "Anything else you noticed in this conference?" Nina responds by briefly evaluating the conference in the videotape saying, "I liked that it wasn't a five minute conference" (lines 2-3). This evaluation serves as the entry point for her small story, which follows a problem/solution structure. In IU2 she sets the scene (the language arts classroom), the characters (she and Luke), and the action (conferring about independent reading books). In IU3 she presents the problem as students "fake reading" (line 22) during independent reading time and suggests that one solution is to help them find easier books. In IU4, she proposes short conferences "between 2 and 3 minutes" (line 40) as another possible solution to the problem, arguing that it gives her more time to "touch base with every kid" (line 47) to ensure comprehension. IU5 serves as a coda, wrapping up the story and reiterating her 
point that conferences should be about checking in with each student and "making sure they're understanding it" (line 54). In IU6, Sarah responds to Nina's small story by offering an alternative purpose of conferring, "focusing on the strategy of questioning" (line 66). In IU7, Nina asserts that she and Luke do focus on reading strategies "at the end of each conference" (line 91).

\begin{tabular}{|c|c|c|c|}
\hline \multicolumn{4}{|c|}{ Transcript of Nina's Small Story } \\
\hline Line & Speaker & Transcription & Contextualization Cues \\
\hline \multicolumn{4}{|c|}{ Interactional Unit (IU) 1: Evaluation of Video } \\
\hline 1 & $\begin{array}{l}\text { Sarah } \\
\rightarrow \\
\text { Group }\end{array}$ & anything else you noticed in this conference $\uparrow \mid$ that & \\
\hline $\begin{array}{l}2 \\
3 \\
4 \\
5 \\
6\end{array}$ & $\begin{array}{l}\text { Nina } \rightarrow \\
\text { Sarah }\end{array}$ & $\begin{array}{l}\text { I liked that it wasn't } \\
\text { a five minute conference } \downarrow \\
\text { it was } \\
\text { you know } \\
2 \text { or } 3 \text { minutes }\end{array}$ & $\begin{array}{l}\text { Nina makes a vertical } \\
\text { motion through the air } \\
\text { with her hands to } \\
\text { emphasize what she is } \\
\text { saying and nods. }\end{array}$ \\
\hline 7 & $\begin{array}{l}\text { Sarah } \\
\rightarrow \text { Nina }\end{array}$ & hm.mm & $\begin{array}{l}\text { Sarah mimics the } \\
\text { above gestures. }\end{array}$ \\
\hline $\begin{array}{l}8 \\
9 \\
10\end{array}$ & $\begin{array}{l}\text { Nina } \rightarrow \\
\text { Sarah }\end{array}$ & $\begin{array}{l}\text { And to the point } \\
\text { And it didn't just go on and on and on } \\
\text { I like that } \downarrow\end{array}$ & \\
\hline \multicolumn{4}{|c|}{ IU2: Setting the Scene } \\
\hline $\begin{array}{l}11 \\
12\end{array}$ & $\begin{array}{l}\text { Nina } \rightarrow \\
\text { Sarah }\end{array}$ & $\begin{array}{l}\text { "cause I have kind of found that } \\
\text { we have been conferring in our language arts class } \uparrow\end{array}$ & \\
\hline 13 & $\begin{array}{l}\text { Sarah } \\
\rightarrow \text { Nina }\end{array}$ & hm.mm & Nodding \\
\hline $\begin{array}{l}14 \\
15\end{array}$ & $\begin{array}{l}\text { Nina } \rightarrow \\
\text { Sarah }\end{array}$ & $\begin{array}{l}\text { and | Luke and I have each taken half of the class } \\
\text { and every day at the beginning of the hour }\end{array}$ & \\
\hline 16 & $\begin{array}{l}\text { Sarah } \\
\rightarrow \text { Nina }\end{array}$ & $\mathrm{hm} . \mathrm{mm}$ & Nodding \\
\hline $\begin{array}{l}17 \\
18 \\
19\end{array}$ & $\begin{array}{l}\text { Nina } \rightarrow \\
\text { Sarah }\end{array}$ & $\begin{array}{l}\text { w:e confer with each student } \\
\text { about what they're reading } \\
\text { their independent reading book }\end{array}$ & \\
\hline 20 & $\begin{array}{l}\text { Sarah } \\
\rightarrow \text { Nina }\end{array}$ & hm.mm & Nodding \\
\hline \multicolumn{4}{|c|}{ IU3: Explaining the problem and offering one solution } \\
\hline $\begin{array}{l}21 \\
22\end{array}$ & $\begin{array}{l}\text { Nina } \rightarrow \\
\text { Sarah }\end{array}$ & $\begin{array}{l}\text { and it kinda makes them accountable } \downarrow \\
\text { s:o they're not sitting there fake reading } \mid \underline{\text { or }}\end{array}$ & \\
\hline 23 & $\begin{array}{l}\text { Sarah } \\
\rightarrow \text { Nina }\end{array}$ & hm.mm & Sarah looks down. \\
\hline $\begin{array}{l}24 \\
25 \\
26 \\
27 \\
28 \\
\end{array}$ & $\begin{array}{l}\text { Nina } \rightarrow \\
\text { Sarah }\end{array}$ & $\begin{array}{l}\text { you know } \\
\text { and we know } \\
\text { we can tell if they're comprehending } \\
\text { like I've done } \\
\text { I've changed, }\end{array}$ & \\
\hline
\end{tabular}




\begin{tabular}{|c|c|c|c|}
\hline $\begin{array}{l}29 \\
30 \\
31 \\
32\end{array}$ & & $\begin{array}{l}\text { I had kids } \\
\text { probably } 5 \text { or } 6 \text { ki:ds change books } \downarrow \\
\text { because they're not comprehending it } \\
\text { and I can tell }\end{array}$ & \\
\hline 33 & $\begin{array}{l}\text { Sarah } \\
\rightarrow \text { Nina }\end{array}$ & hm.mm & Sarah looks down. \\
\hline $\begin{array}{l}34 \\
35 \\
36 \\
37\end{array}$ & $\begin{array}{l}\text { Nina } \rightarrow \\
\text { Sarah }\end{array}$ & $\begin{array}{l}\text { you know } \\
\text { I'm like hey you know what } \uparrow \\
\text { this is probably a little bit too hard for you } \\
\text { let's try to find another book }\end{array}$ & \\
\hline 38 & $\begin{array}{l}\text { Sarah } \\
\rightarrow \text { Nina }\end{array}$ & right & \\
\hline \multicolumn{4}{|c|}{ IU4: Offering a second solution } \\
\hline $\begin{array}{l}39 \\
40\end{array}$ & $\begin{array}{l}\text { Nina } \rightarrow \\
\text { Group }\end{array}$ & $\begin{array}{l}\text { but } \mid \text { you know } \\
\text { we're trying to have our conferences between } 2 \text { and } 3 \\
\text { minutes } \\
\text { and that's all }\end{array}$ & \\
\hline 42 & $\begin{array}{l}\text { Sarah } \\
\rightarrow \text { Nina }\end{array}$ & hm.mm & \\
\hline $\begin{array}{l}43 \\
44 \\
45 \\
\end{array}$ & $\begin{array}{l}\text { Nina } \rightarrow \\
\text { Sarah }\end{array}$ & $\begin{array}{l}\text { I mean } \\
\text { you have to so you can } \\
\text { you know }\end{array}$ & \\
\hline 46 & $\begin{array}{l}\text { Sarah } \\
\rightarrow \text { Nina } \\
\end{array}$ & right & \\
\hline $\begin{array}{l}47 \\
48\end{array}$ & $\begin{array}{l}\text { Nina } \rightarrow \\
\text { Sarah }\end{array}$ & $\begin{array}{l}\text { try to touch base with every kid } \downarrow \\
\text { but }\end{array}$ & \\
\hline 49 & $\begin{array}{l}\text { Sarah } \\
\rightarrow \text { Nina }\end{array}$ & hm.mm & $\begin{array}{l}\text { Sarah purses her lips } \\
\text { slightly. }\end{array}$ \\
\hline \multicolumn{4}{|c|}{ IU5: Coda } \\
\hline $\begin{array}{l}50 \\
51 \\
52\end{array}$ & $\begin{array}{l}\text { Nina } \rightarrow \\
\text { Sarah }\end{array}$ & $\begin{array}{l}\text { I like that's it's not } \\
\text { you know } \\
\text { it's a touching base with them } \downarrow\end{array}$ & \\
\hline 53 & $\begin{array}{l}\text { Sarah } \\
\rightarrow \text { Nina }\end{array}$ & $\mathrm{hm} \cdot \mathrm{mm}$ & \\
\hline $\begin{array}{l}54 \\
55\end{array}$ & $\begin{array}{l}\text { Nina } \rightarrow \\
\text { Sarah }\end{array}$ & $\begin{array}{l}\text { And making sure they're understanding it } \\
\text { And stuff like that }\end{array}$ & \\
\hline 56 & $\begin{array}{l}\text { Sarah } \\
\rightarrow \text { Nina }\end{array}$ & yeah & \\
\hline $\begin{array}{l}57 \\
58\end{array}$ & $\begin{array}{l}\text { Nina } \rightarrow \\
\text { Sarah }\end{array}$ & $\begin{array}{l}\text { because that's kind of what we're doing } \\
\text { in language arts class }\end{array}$ & \\
\hline \multicolumn{4}{|c|}{ IU6: Sarah's response to story } \\
\hline $\begin{array}{l}59 \\
60 \\
61 \\
62 \\
63 \\
64 \\
65 \\
66 \\
67 \\
68 \\
69 \\
70 \\
71\end{array}$ & $\begin{array}{l}\text { Sarah } \\
\rightarrow \text { Nina }\end{array}$ & $\begin{array}{l}\text { hm.mm } \\
\text { and there are } \\
\text { I mean } \\
\text { there is that touch base type of conference } \\
\text { and then } \\
\text { you know } \\
\text { there's like this type of conference } \\
\underline{\text { she is focusing on the strategy of questioning }} \text { and so she's giving him that strategy to continue to use } \downarrow \\
\text { and I think } \\
\text { even with their independent books } \\
\text { you can talk about them } \\
\text { you know }\end{array}$ & \\
\hline
\end{tabular}




\begin{tabular}{|l|l|l|l|}
\hline 72 & & have you used some strata.... & \\
73 & & you know & \\
74 & & strategies in your reading $\uparrow$ & \\
75 & & you know & \\
76 & & what did you tr:y \\
77 & & to help you understand the story better $\uparrow$ & \\
78 & & you know & \\
79 & & to see if they've even tried & \\
80 & & sometimes they just give up & \\
81 & & but have you tried some things & \\
82 & & that would help you understand the story better $\uparrow$ & \\
\hline IU7: Nina's response to Sarah & \\
\hline 83 & Nina $\rightarrow$ & yeah & \\
84 & Sarah & and we do that at the very end $\mid$ at the end we & \\
85 & & you know & \\
86 & & okay do you have a prediction $\uparrow$ & you know \\
87 & & tell us $\mid$ tell me about a character or something & \\
88 & & hm.mm & \\
\hline 89 & Sarah & sure & \\
90 & $\rightarrow$ Nina & we try to do that at the end of each conference & \\
\hline 91 & Nina $\rightarrow$ & so & \\
92 & Sarah & &
\end{tabular}

Although this interaction is essentially a disagreement about the purposes of conferring and the appropriate instructional content for reading conferences, it does not immediately appear to be a conflict because both Sarah and Nina use discursive moves to build consensus and lessen the force of their arguments. For instance, Nina uses hedges such as "I have kind of found that" (line 11) and "we try to do that" (line 91). They attempt to build consensus with the frequent use of you know. Additionally, Nina shows her acceptance of Sarah's position as the leader by directing her gaze mostly in her direction. The illusion of agreement and collaboration is co-constructed despite an ultimately unresolved disagreement about the purposes of conferences.

Sarah further maintains this sense of agreement by interjecting with affirmative evaluative comments such as hm.mm, right, and yeah accompanied by enthusiastic nodding and a mimicking of Nina's gestures. She uses such interjections and nodding throughout the entire coaching event, but she uses them with significantly higher 
frequency during Nina's small story. These sorts of interjections are known as back channels within the field of conversation analysis (Goffman, 1976; Schegloff, 1982; Yngve, 1970) and can serve various purposes such as signaling active listening, encouraging the speaker to continue, and indicating understanding. However, they may carry other meanings based on tone, prosody, intonation, and gesture (Heylen \& op den Akker, 2006). In this case, the increased frequency of back channels along with a slight change in tone, an averted gaze in lines 23 and 33, and a pursing of the lips in line 49 indicate that Sarah is not signaling sincere agreement; rather she is attempting to align herself with Nina in preparation for the counter argument that she is about to make in IU6 (McClave, 2000; Ogden, 2006). In other words, she positions herself as a collaborative, agreeable colleague in order to gain a platform from which to assert her opinions about effective reading conferences.

The conflict in this interaction revolves around Nina's two claims about reading conferences. First, she argues that the purpose of reading conferences is to hold students accountable and to make sure that they comprehend what they are reading. Sarah briefly acknowledges that "there is that touch base type of conference" (line 62) but then immediately attempts to redirect Nina to what she considers a more appropriate purpose for conferring, strategy instruction (lines 65-67). Secondly, Nina argues that the appropriate instructional content of the conference should be to question for understanding and then to assist students in choosing appropriate books based on that information. In lines 68-82, Sarah argues for having students try reading strategies to attempt challenging texts rather than having them select an easier book. 
There is, arguably, a third conflict in this small story based on their beliefs about student development and learning. Nina claims that students need to be held accountable to stay on task and that reading development requires practice with easy texts (lines 2122). Sarah, on the other hand seems to believe that students need encouragement because “sometimes they just give up" (line 80). She claims that the students' reading development depends on proper scaffolding to help students "understand the story better" (line 82) through the effective use of reading strategies.

Sarah and Nina draw on different loci of knowledge and power to support their positions about the purposes of conferences and the nature of student learning. For instance, Sarah begins the interaction by referring to the video as the source for the discussion of conferring. She asks, "Anything else you noticed in this conference?" (line 1). Nina offers an alternative knowledge base for conferring by situating her narrative within past collaborative practice when she states, "we have been conferring in our language arts class" (line 12). She claims every day, practical knowledge by emphasizing her routine experience of conferring "every day at the beginning of the hour" (line 15) with "each student" (line 17). She strengthens her arguments by using collective pronouns to align herself with her co-teacher. For example, in line 40 she states, "we're trying to have our conferences between 2 and 3 minutes." With her use of the plural "we're," Nina personalizes her claims and bases them in the group knowledge of the teachers. She further emphasizes the value of teachers' observational knowledge in lines 25 and 26, "And we know. We can tell if they're comprehending."

In contrast, Sarah draws mostly on outside expertise as a knowledge building tool. In lines 65-67, she refers back to expertise of the teacher in the video to support her 
argument that strategy instruction should be the main focus of reading conferences arguing, "She is focusing on the strategy of questioning." She further draws on notions of best practices when she talks about "types" of conferences (lines 62, 65) as if there is a complete and bounded list of possibilities for conferring. Within this Discourse, particular procedures, defined and marketized by outside experts, become a way to "create places in conformity with abstract models" (de Certeau, 1984, p. 29). Nina's ideas about how to confer are only counted as valid if they align with one of the sanctioned "types" of conferences, and there is little room for negotiation of the purposes and proper uses of the instructional practice. "What is counted is what is used, not the ways of using" (de Certeau, 1984, p. 35).

In IU6, Sarah takes an explanatory stance with her long turn of talk and her explanatory gestures. She then attempts, in lines $72-82$ to present her argument in terms of classroom experience as Nina has done, but she does so in a performative modeling of possible future talk with students when she talks as if she if talking to students in lines 72-77 and 81 and 82. She seems to recognize the teachers' desire to situate the discussion within past classroom experience but does not have a proper footing (Goffman, 1981) to do so effectively because she does not currently have a classroom of her own.

Throughout the sub-event, Nina draws on practical, classroom experience with an orientation to the past and collaborative meaning making. Sarah draws on the outside expertise of the video and of "types of conferences" with an orientation to the future and to knowledge transfer.

Power is constructed and contested in interesting ways in this interaction. While Sarah maintains a position of power within the interaction as the facilitator of the 
conversation who largely sets the agenda and confirms what counts as knowledge, that power does not extend outside of the current space into the classroom because Nina ultimately does not change her practice. Sarah aims to change existing practices through her explanation of best practices. Instead, Nina appropriates the idea of conferring as a best practice to match and confirm her existing instructional practices. Indeed, during individual interviews she said, "bring the kid up and talk to them, oh my gosh, well, I do that all the time" (Interview, 12/5/12), and she claimed that the only difference is that now she writes it down. In de Certeau's words, Nina is among the multitude of productive consumers who, through their creative consumption, "make (bricolent) innumerable and infinitesimal transformations of and within the dominant cultural economy in order to adapt it to their own interests and their own rules" (p. xiv).

Throughout this interaction, Sarah and Nina work to present themselves as certain kinds of people in relation to local notions about what constitutes effective teaching practices and professional collaboration. Both Nina and Sarah attempt to position themselves as competent and collaborative professionals who enthusiastically implement best practices and work together well. This indicates a certain level of vulnerability in that they must demonstrate their expertise through alignment with district initiatives (Kelchtermans, 2005; Lasky, 2005; MacGillivray et al., 2004) in order to save professional face (Goffman, 1967). Sarah seems to see her job as ensuring the effective implementation of effective conferring. Nina appears to be concerned with presenting herself as someone who knows about conferences and is working to implement them effectively. Thus, the interaction is ultimately about their desire to be viewed by 
themselves and others as a "good teacher" or a "good coach" rather than about coming to a consensus about the purposes and content of reading conferences.

\section{Teachers' Request for Localization and Relevance}

In the final minutes of the coaching event, after they have finished discussing the video, Sarah asks if they would like to watch another one (See Table 5.3 for a transcript of this sub-event). Danielle says, "I'd love to watch you" (line 2) and the rest of the group agrees. Amy suggests that it would be most beneficial to watch one of their colleagues, Heidi, conduct a math conference. Sarah explains that, although she has video of Heidi, she cannot share it because she does not have her permission. Then, Amy elaborates on her desire to view videos of conferring that are "an actually good source" (line 38). At first glance, this interaction appears to be a simple, fleeting discussion about what to watch next, but it has interesting implications about where to locate knowledge about best practices and which sources are the most valuable.

\begin{tabular}{|c|c|c|c|}
\hline $\begin{array}{l}\text { Table } \\
\text { Tran }\end{array}$ & ript of Teachers' $R$ & est for Localization and Relevanc & \\
\hline Line & Speaker & Transcription & $\begin{array}{c}\text { Contextualization } \\
\text { Cues }\end{array}$ \\
\hline \multicolumn{4}{|c|}{ IU1: Request to see Sarah do a conference } \\
\hline 1 & Sarah $\rightarrow$ Group & so we'll watch another one $\uparrow$ & \\
\hline 2 & Danielle $\rightarrow$ Sarah & I'd love to watch you & Enthusiastic tone \\
\hline 3 & Sarah $\rightarrow$ Group & you want to watch m:e $\uparrow$ & \\
\hline 4 & Group $\rightarrow$ Sarah & ye:ah & Enthusiastic tone \\
\hline 5 & Sarah $\rightarrow$ Group & $\underline{\text { re:ally } \uparrow}$ & $\begin{array}{l}\text { Sarah is at the front } \\
\text { of the room, off } \\
\text { camera and having } \\
\text { trouble finding the } \\
\text { video she wants. }\end{array}$ \\
\hline \multicolumn{4}{|c|}{ IU2: Request to see a local teacher do a conference or to see a produced content area conference } \\
\hline $\begin{array}{l}6 \\
7 \\
8 \\
9\end{array}$ & Amy $\rightarrow$ Sarah & $\begin{array}{l}\text { in Heidi’s class } \\
\text { did Heidi do the conference } \uparrow \\
\text { or did you do the conferencing } \uparrow \\
\text { you said you videotaped it }\end{array}$ & \\
\hline $\begin{array}{l}10 \\
11 \\
12\end{array}$ & Sarah $\rightarrow$ Group & $\begin{array}{l}\text { um | this particular one } \\
\text { um| I did } \\
\text { um | Heidi did math }\end{array}$ & \\
\hline
\end{tabular}




\begin{tabular}{|c|c|c|c|}
\hline 13 & & but I did a science one & \\
\hline 14 & Amy $\rightarrow$ Sarah & so did you videotape Heidi doing math $\uparrow$ & \\
\hline $\begin{array}{l}15 \\
16 \\
\end{array}$ & Sarah $\rightarrow$ Amy & I did but I didn't ask her if I could share it with you & \\
\hline 17 & Amy $\rightarrow$ Sarah & okay & \\
\hline 18 & Sarah $\rightarrow$ Amy & so I'd rather [ask her first but & \\
\hline $\begin{array}{l}19 \\
20 \\
21 \\
22\end{array}$ & Amy $\rightarrow$ Sarah & $\begin{array}{l}\text { well if you'd ask her later } \uparrow] \\
\text { because I } \\
\text { when we watch all these videos } \\
\text { I'm like not seeing math ones }\end{array}$ & $\begin{array}{l}\text { shrugs } \\
\text { laughs as she says } \\
\text { this }\end{array}$ \\
\hline 23 & Sarah $\rightarrow$ Amy & no & \\
\hline 24 & Amy $\rightarrow$ Sarah & I know that this system's set up for reading & $\begin{array}{l}\text { gestures towards } \\
\text { screen }\end{array}$ \\
\hline $\begin{array}{l}25 \\
26 \\
27\end{array}$ & Sarah $\rightarrow$ Amy & $\begin{array}{l}\text { no } \\
\text { I'm sure she would be fine } \\
\text { but I would rather ask her first }\end{array}$ & \\
\hline $\begin{array}{l}28 \\
29 \\
30 \\
31 \\
32 \\
33 \\
34 \\
35 \\
36 \\
37 \\
38 \\
39 \\
40 \\
\end{array}$ & Amy $\rightarrow$ Sarah & $\begin{array}{l}\text { yeah } \\
\text { I just didn't know } \\
\text { like if they do } \\
\text { I know this whole thing is about } \\
\text { like the reading conferring } \\
\text { that's why they put the videos out | the company } \\
\text { but I didn't know } \\
\text { if there was a lot out there } \\
\text { where you could watch } \\
\text { people do |conferring in math } \\
\text { and an actually good | source } \\
\text { not like a you tube video } \\
\text { that you watch someone doing it or something }\end{array}$ & $\begin{array}{l}\text { gestures towards } \\
\text { screen }\end{array}$ \\
\hline $\begin{array}{l}41 \\
42 \\
43 \\
\end{array}$ & Sarah $\rightarrow$ Amy & $\begin{array}{l}\text { right } \\
\text { there are } \\
\text { um| and we're trying to get more videos }\end{array}$ & \\
\hline 44 & Amy $\rightarrow$ Sarah & or science or social studies & \\
\hline
\end{tabular}

In IU1, the teachers are essentially asking for more localized examples of conferences. They also position Sarah as a valuable source of knowledge when they ask her to share a video of herself conferring with students. In IU2, Amy challenges Sarah's position by asking to see Heidi confer instead, thus suggesting that the teacher's work is a more relevant source for learning about conferring. Furthermore, she challenges the relevancy of the published videos because they do not meet her needs as a math teacher. This objection indicates that she does not view the practices modeled within the 
published videos as a universal best practice, but believes that teachers need different instructional strategies when conferring in math.

Although she dismisses "all of these videos" (line 21) as irrelevant for math, she simultaneously acknowledges their authoritative power. She seems to recognize the videos of conferring as a commodity that "the company" puts out to push their own agenda. For example, she says, "this system's set up for reading" (line 24) and "this whole thing is about, like, the reading conferring" (lines 31-32). These comments illustrate Amy's awareness that workshop methods and procedures, which are considered best practices within her learning community, have been "transformed into a thing for sale" (Shannon, 2001, p. 11) within an increasingly marketized educational context (Bartlett, Frederick, Gulbrandsen, \& Murillo, 2002).

Amy does not, however, fully accept a position as a passive consumer of commodified best practices. Instead, she simultaneously accepts and questions the value of the published videos. She wants to know if there are other authoritative sources "out there" (line 35) that are "an actually good source" (line 38). She sees such sources as more trustworthy than "a YouTube video that you watch someone doing it or something" (lines 39-40). This viewpoint reflects her belief that "If this is the model of how you do something, and research shows it's done this way, you can't tweak it the way you want" (Interview, 12/13/12). Thus, Amy wants to see video of teachers, such as Heidi, in daily practice in real math classrooms but only if they "follow the procedure correctly" (Interview, 12/13/12). This belief seems to be at odds with her earlier indications that best practices are not the same for reading and math. 
The tensions in this interaction illustrate Amy's conflicted positions in relation to the Discourse of best practices. They also highlight the complex negotiations occurring within the learning community about what constitutes valuable knowledge, how best practices are identified, and who has the authority to declare practices effective or ineffective.

\section{Planning Meeting with Tiffany}

In January of 2013, Sarah and Tiffany, a first-year special education teacher, worked together on a writing workshop unit on literary essays in an eighth-grade class of eight special education students. They co-planed the unit, and Sarah attended the class two to three times per week and occasionally taught the mini lesson. On the day that I videotaped, they met in Tiffany's classroom after school to plan the next lesson. The focus of the lesson was on using conversational prompts to add details to the essays. The main activity involved a few students reading a script to the class in which they used some of the prompts to retell stories that they had read together previously. I conducted microanalysis of two brief video segments in which Sarah and Tiffany negotiate instructional decisions and whether or not to videotape the lesson.

The first segment occurred approximately five and a half minutes into their coplanning meeting (See Table 5.4 for a transcript of this segment). In IU1, Sarah suggests the script activity and Tiffany agrees "that would be fun" (line 12). In IU2, Sarah suggests that Tiffany write the script ahead of time and Tiffany concurs. In IU3, Sarah talks through the process of writing the plans on a sticky note, and Tiffany follows her lead. Next, in IU4, Sarah asks to videotape the lesson and Tiffany agrees. In the last unit, 
Tiffany expresses doubt about how the lesson will go, and Sarah briefly acknowledges

her feelings before moving onto the next stage of planning.

\begin{tabular}{|c|c|c|c|c|}
\hline \multicolumn{5}{|c|}{ Planning Meeting with Tiffany } \\
\hline Time & Line & Speaker & Transcription & Contextualization Cues \\
\hline \multicolumn{5}{|r|}{ - } \\
\hline \multirow[t]{10}{*}{$5: 32$} & $\begin{array}{l}1 \\
2 \\
3\end{array}$ & Sarah & $\begin{array}{l}\text { um | when I went back and I read } \\
\text { um | through this mini lesson } \\
\text { I'm using the conversational prompts }\end{array}$ & $\begin{array}{l}\text { Pointing at a spot in } \\
\text { the book. } \\
\text { said as an aside }\end{array}$ \\
\hline & 4 & Tiffany & 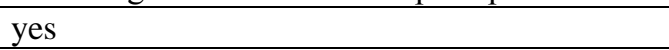 & \\
\hline & $\begin{array}{l}5 \\
6 \\
7\end{array}$ & Sarah & $\begin{array}{l}\text { I wondered } \\
\text { for your } \\
\text { I thought } \| \text { for this class } \| \text { in particular }\end{array}$ & \\
\hline & 8 & Tiffany & [an example $\uparrow$ & \\
\hline & $\begin{array}{c}9 \\
10\end{array}$ & Sarah & $\begin{array}{l}\text { are you thinking that] } \\
\text { you're going to [do that with them } \uparrow\end{array}$ & $\begin{array}{l}\text { Scanning finger up and } \\
\text { down chart in book } \\
\text { that lists the prompts. }\end{array}$ \\
\hline & $\begin{array}{l}11 \\
12\end{array}$ & Tiffany & $\begin{array}{ll}\text { I thought that would be fun } & \text { ye:ah ] }\end{array}$ & $\begin{array}{l}\text { rising pitch on first } \\
\text { syllable and } \\
\text { descending pitch on } \\
\text { second Smiles as she } \\
\text { says it. }\end{array}$ \\
\hline & $\begin{array}{l}13 \\
14 \\
15\end{array}$ & Sarah & $\begin{array}{l}\text { I do too } \downarrow \\
\text { and I think that would be a great way } \\
\text { to have them engaged in it }\end{array}$ & $\begin{array}{l}\text { Sarah moves her hand } \\
\text { in a rotating motion } \\
\text { towards Tiffany as she } \\
\text { speaks and Tiffany } \\
\text { nods. }\end{array}$ \\
\hline & 16 & Tiffany & hm.mm & \\
\hline & $\begin{array}{l}17 \\
18\end{array}$ & Sarah & $\begin{array}{l}\text { and maybe get them to understand it } \\
\text { before we actually have them try it } \mid \text { in writing }\end{array}$ & \\
\hline & 19 & Tiffany & right $\downarrow$ & \\
\hline \multicolumn{5}{|l|}{ IU2 } \\
\hline \multirow[t]{3}{*}{$5: 56$} & $\begin{array}{l}20 \\
21 \\
22 \\
23\end{array}$ & Sarah & $\begin{array}{l}\text { and then I'm wondering to: } \\
\text { this was just a thought that I had } \\
\text { but if we had them go through one } \\
\text { that you already have scripted for them }\end{array}$ & $\begin{array}{l}\text { rising pitch Sarah } \\
\text { places her hand in her } \\
\text { chin } \\
\text { L21: Points at Tiffany, } \\
\text { swipes hand across and } \\
\text { then rests it on her } \\
\text { chest with word "I" } \\
\text { L22: Points to chart in } \\
\text { book } \\
\text { L 23:*rising pitch* } \\
\text { Tiffany nodding }\end{array}$ \\
\hline & 24 & Tiffany & hm.mm & \\
\hline & $\begin{array}{l}25 \\
26\end{array}$ & Sarah & $\begin{array}{l}\text { then have them try it with the other book } \downarrow \\
\text { so maybe if you have scripted }\end{array}$ & $\begin{array}{l}\text { Sarah tilts her head as } \\
\text { she speaks. Tiffany } \\
\text { Nods }\end{array}$ \\
\hline
\end{tabular}




\begin{tabular}{|c|c|c|c|c|}
\hline & 27 & Tiffany & {$[$ Stripes $\uparrow$} & \\
\hline & $\begin{array}{l}28 \\
29 \\
30 \\
31 \\
32 \\
33 \\
34\end{array}$ & Sarah & $\begin{array}{l}\text { Those] } \\
\text { Stripes } \\
\text { then maybe have them try it } \\
\text { with either Those Shoes or Owl Moon } \downarrow \\
\text { and then the one they don't choose to talk about } \\
\text { we could have them write about } \\
\text { so we could }\end{array}$ & $\begin{array}{l}\text { Gives hand gestures to } \\
\text { emphasize choices. } \\
\text { Shakes her head in a } \\
\text { horizontal motion. }\end{array}$ \\
\hline & 35 & Tiffany & okay $\downarrow$ & \\
\hline & 36 & Sarah & build upon what you do [with them first $\uparrow$ & $\begin{array}{l}\text { Drops chin and looks } \\
\text { up at Tiffany. } \\
\text { Flat hand gesture high, } \\
\text { medium, low in air }\end{array}$ \\
\hline & 37 & Tiffany & that'll work |uh,huh] & Nodding \\
\hline & 38 & Sarah & does that make sense $\uparrow$ & \\
\hline & 39 & & ye:ah & $\begin{array}{l}\text { rising pitch on first } \\
\text { syllable and } \\
\text { descending pitch on } \\
\text { second }\end{array}$ \\
\hline \multicolumn{5}{|l|}{ IU3 } \\
\hline \multirow[t]{6}{*}{$6: 25$} & 40 & Sarah & I'm going to put that on a sticky note because & $\begin{array}{l}\text { Both of them write } \\
\text { down plans on sticky } \\
\text { notes as Sarah talks. }\end{array}$ \\
\hline & 41 & Tiffany & so this is Friday & \\
\hline & $\begin{array}{l}42 \\
43 \\
44 \\
45 \\
46 \\
47\end{array}$ & Sarah & $\begin{array}{l}\text { so } \mid \text { Stripes you'll use as |as the |um| scripted } \downarrow \\
\text { right } \uparrow \\
\text { and then |um| they get to choose } \\
\text { either The Shoes or Owl Moon } \\
\text { and then they'll have their own conversation } \\
\text { using the push your thinking prompts }\end{array}$ & $\begin{array}{l}\text { Sarah has hand out } \\
\text { palm up }\end{array}$ \\
\hline & 48 & Tiffany & right $\downarrow$ & \\
\hline & $\begin{array}{l}49 \\
50 \\
51 \\
\end{array}$ & Sarah & $\begin{array}{l}\text { with a partner }\|\| \| \\
\text { and then when they write } \\
\text { they choose the other } \downarrow\end{array}$ & \\
\hline & 52 & Tiffany & yes & \\
\hline \multicolumn{5}{|l|}{ IU4 } \\
\hline \multirow[t]{6}{*}{$7: 01$} & $\begin{array}{l}53 \\
54 \\
55 \\
56 \\
57\end{array}$ & Sarah & $\begin{array}{l}\text { so I'm wondering } \\
\text { I'm just going to ask you this } \\
\text { and you can say no } \uparrow \\
\text { but I'm wondering } \\
\text { if you would want me to video tape this } \\
\text { lesson } \downarrow\end{array}$ & $\begin{array}{l}\text { Tiffany smiles. } \\
\text { Sarah nodding her } \\
\text { head as she speaks. }\end{array}$ \\
\hline & 58 & Tiffany & okay $\downarrow$ & \\
\hline & $\begin{array}{l}59 \\
60\end{array}$ & Sarah & $\begin{array}{l}\text { for us to then look at } \\
\text { to see how it motivates your kids and }\end{array}$ & $\begin{array}{l}\text { Sarah moves her hand } \\
\text { in a rotating motion } \\
\text { towards Tiffany as she } \\
\text { speaks. }\end{array}$ \\
\hline & 61 & Tiffany & hm.mm & \\
\hline & $\begin{array}{l}62 \\
63\end{array}$ & Sarah & $\begin{array}{l}\text { I mean } \mid \\
\text { would that be something you would want to } \\
\text { have [ videotaped } \uparrow\end{array}$ & $\begin{array}{l}\text { Sarah leans slightly } \\
\text { towards Tiffany, } \\
\text { nodding head. }\end{array}$ \\
\hline & 64 & Tiffany & * ye:ah* & $\begin{array}{l}\text { rising pitch on first } \\
\text { syllable and }\end{array}$ \\
\hline
\end{tabular}




\begin{tabular}{|c|c|c|c|c|}
\hline & & & & $\begin{array}{l}\text { descending pitch on } \\
\text { second }\end{array}$ \\
\hline & $\begin{array}{l}65 \\
66 \\
67\end{array}$ & Sarah & $\begin{array}{l}\text { to kind ] of see } \\
\text { you know } \\
\text { if through doing this layered type of }\end{array}$ & $\begin{array}{l}\text { Sarah moves her hand } \\
\text { in a rotating motion } \\
\text { towards Tiffany as she } \\
\text { speaks and Tiffany } \\
\text { nods. }\end{array}$ \\
\hline & 68 & Tiffany & I think so & \\
\hline & 69 & Sarah & then we could see if their [understanding & $\begin{array}{l}\text { Sarah has hand out } \\
\text { palm up. Tiffany } \\
\text { nodding. }\end{array}$ \\
\hline & 70 & Tiffany & hm.mm & \\
\hline & $\begin{array}{l}71 \\
72\end{array}$ & Sarah & $\begin{array}{l}\text { is better ] } \\
\text { or land like the engagement }\end{array}$ & \\
\hline & 73 & Tiffany & yeah I would like that & \\
\hline & 74 & Sarah & okay $\downarrow$ & \\
\hline IU5 & & & & \\
\hline $7: 27$ & 75 & Tiffany & because I think this could be really $\mid$ good $\downarrow$ & \\
\hline & 76 & Sarah & I do too $\downarrow$ & $\begin{array}{l}\text { Nodding head } \\
\text { vigorously. }\end{array}$ \\
\hline & $\begin{array}{l}77 \\
78\end{array}$ & Tiffany & $\begin{array}{l}\text { or it could be really ba:ad } \\
\text { That's why I'm like }\end{array}$ & $\begin{array}{l}\text { *laughing through this } \\
\text { phrase, drawing out } \\
\text { bad because of } \\
\text { laughter. } \\
\text { They both laugh and } \\
\text { lean in a little bit } \\
\text { towards each other. } \\
\text { Sarah leans back in } \\
\text { chair and covers her } \\
\text { mouth then leans } \\
\text { forward again. }\end{array}$ \\
\hline & 79 & Sarah & I know & smiling \\
\hline & 80 & Tiffany & [like all the blank & $\begin{array}{l}\text { smiling and waves } \\
\text { hand in front of her } \\
\text { face }\end{array}$ \\
\hline & 81 & Sarah & I know & smiling \\
\hline & 82 & Tiffany & $\begin{array}{l}\text { faces] } \\
\text { and then [oh no }\end{array}$ & $\begin{array}{l}\text { looks up towards } \\
\text { ceiling briefly. }\end{array}$ \\
\hline & 83 & Sarah & well & $\begin{array}{l}\text { leaning body and head } \\
\text { to one side. }\end{array}$ \\
\hline & 84 & Tiffany & what ] am I going to do $\uparrow$ & $\begin{array}{l}\text { Tiffany laughing. } \\
\text { Sarah leaning over text }\end{array}$ \\
\hline
\end{tabular}

The second segment consists of the last few minutes of the meeting when Sarah remembers that she will be absent on the day of the lesson and will not be there to videotape it (See Table 5.5. for a transcript of this segment). Tiffany responds by expressing nervousness about doing the lesson without Sarah there. In IU2, they negotiate 
whether or not they will videotape the lesson, and they discuss the logistics of obtaining the video. I present segments one and two before providing an analysis because the conversational thread and my discussion of their interaction spans both segments.

\begin{tabular}{|c|c|c|c|c|}
\hline \multicolumn{5}{|c|}{ Tranccrint of Sogmont Two of Plannino Meoting with Tiffany, } \\
\hline Time & Line & Speaker & Transcription & Contextualization Cues \\
\hline \multicolumn{5}{|c|}{ Interactional Unit (IU) 1} \\
\hline \multirow[t]{6}{*}{$27: 00$} & $\begin{array}{l}1 \\
2 \\
3 \\
4 \\
5 \\
6\end{array}$ & Sarah & $\begin{array}{l}\text { *o:h my goodness* }^{*} \\
\text { you know what } \uparrow \\
\text { I can't come in and videotape Tuesday } \\
\text { it's my mom's surgery } \\
\text { I won't be here } \\
\text { in the building | so }\end{array}$ & $\begin{array}{l}\text { *said with a rising then } \\
\text { falling intonation* }\end{array}$ \\
\hline & 7 & Tiffany & okay & \\
\hline & $\begin{array}{c}8 \\
9 \\
10 \\
11 \\
12 \\
13 \\
\end{array}$ & Sarah & $\begin{array}{l}\text { let's see if we can get someone else to do it } \\
\text { no| well | } \\
\text { because I want to be the one to videotape } \\
\text { or actually lit doesn't matter } \\
\text { because I'll need to look at it again } \\
\text { you know |I mean it's }\end{array}$ & \\
\hline & $\begin{array}{l}14 \\
15\end{array}$ & Tiffany & 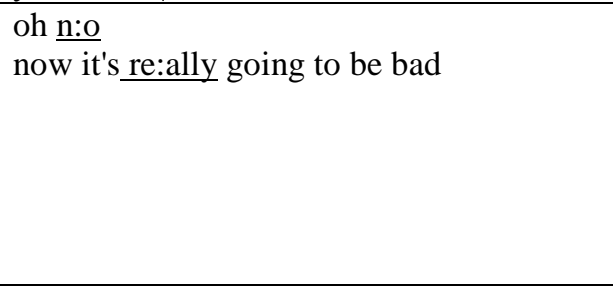 & $\begin{array}{l}\text { Tiffany smiles and } \\
\text { laughs slightly at end of } \\
\text { sentence. Sarah opens } \\
\text { mouth wide, throws } \\
\text { down pen and leans } \\
\text { way forward and then } \\
\text { back, laughing. }\end{array}$ \\
\hline & $\begin{array}{l}16 \\
17\end{array}$ & Sarah & $\begin{array}{l}\text { it's not going to be ba:d } \\
\text { because you're doing the lesson *anyway* }\end{array}$ & $\begin{array}{l}\text { *high pitched* } \\
\text { Sarah leans forward and } \\
\text { tilts head, smiling. } \\
\text { Tiffany leans back in } \\
\text { chair, laughing. }\end{array}$ \\
\hline & 18 & Tiffany & I know & laughing \\
\hline \multicolumn{5}{|l|}{ IU2 } \\
\hline \multirow[t]{4}{*}{$28: 16$} & $\begin{array}{l}19 \\
20 \\
21 \\
22\end{array}$ & Sarah & $\begin{array}{l}\text { but if | if we could just } \\
\text { I don't care } \\
\text { I mean we don't have to videotape that day } \\
\text { it's up to you }\end{array}$ & $\begin{array}{l}\text { Sarah sits up straighter } \\
\text { and folds hands in front } \\
\text { of her. } \\
\text { Sarah shakes her head. } \\
\text { Tiffany nods. }\end{array}$ \\
\hline & 23 & Tiffany & okay & \\
\hline & $\begin{array}{l}24 \\
25 \\
26\end{array}$ & Sarah & $\begin{array}{l}\text { I just remembered that } \downarrow \\
\text { that I'm not going to be here Tuesday } \\
\text { *darn it* }\end{array}$ & $\begin{array}{l}\text { *whispered with } \\
\text { scrunched up face* }\end{array}$ \\
\hline & $\begin{array}{l}27 \\
28\end{array}$ & Tiffany & $\begin{array}{l}\text { I forgot that } \\
\text { I remember you saying that }\end{array}$ & \\
\hline
\end{tabular}




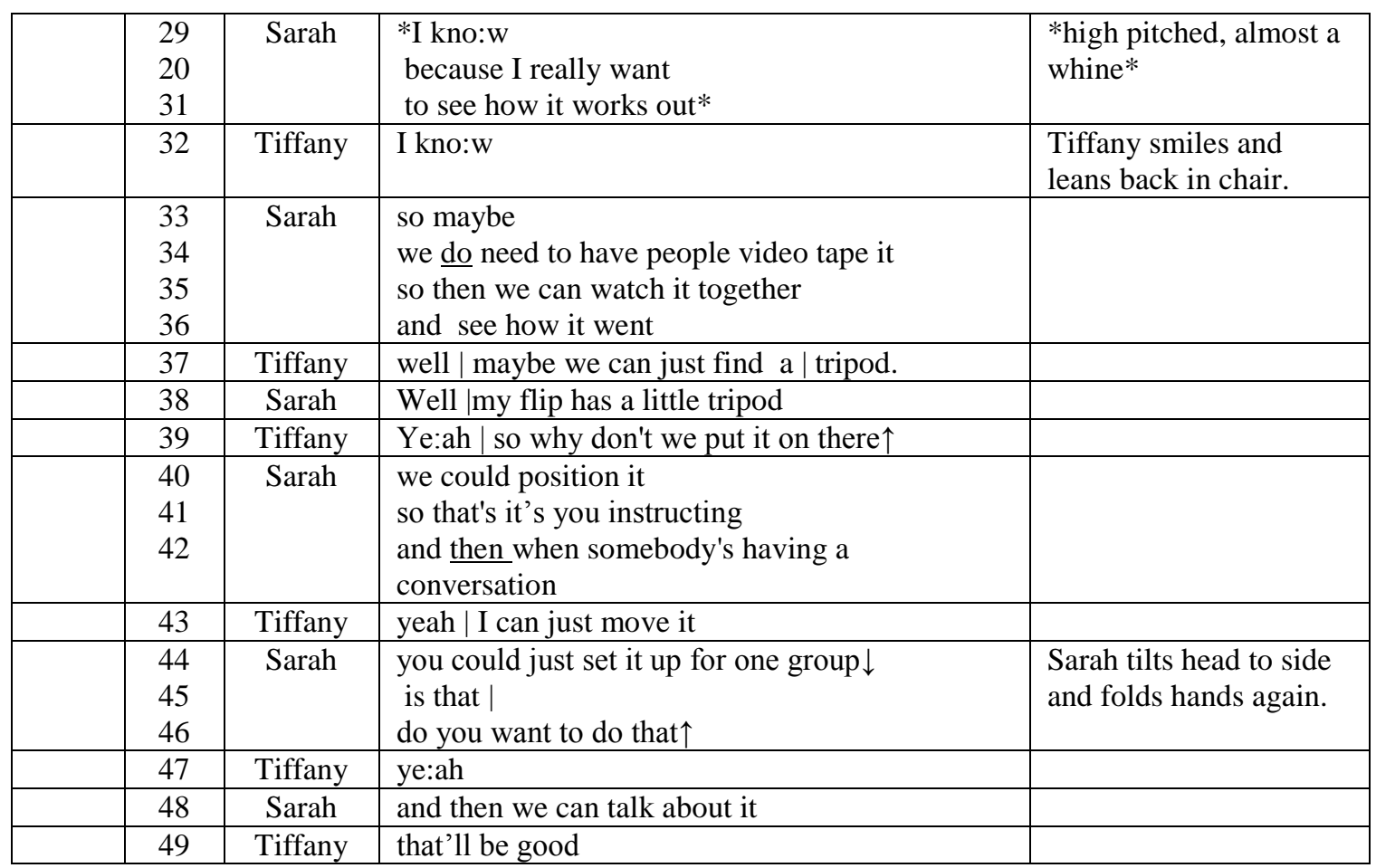

In the first segment, Sarah simultaneously positions herself as a collaborator and as an expert leader. She positions herself as the leader by dominating the flow and content of the conversation, doing most of the talking, taking an explanatory stance, and making all of the suggestions for the lesson. She initiates the first four interactional units in the first person and does most of the talking. Many of her turns of talk consist of several message units while Tiffany's turns are, with the exception of IU5, brief and confirmatory. Sarah uses a series of hand gestures and gaze patterns that indicate an explanatory stance (as in lines 20-29). Her downward intonation in lines 25, 31, 42, and 51 further emphasizes this stance as does her check for understanding in line 38.

Sarah further positions herself as the leader by making the suggestions for the lesson. She suggests using a script (lines 5-15), writing the script in advance (lines 2023), and videotaping (lines 53-56). Through her immediate acceptance of these 
suggestions (lines 11-12, 16, 48), Tiffany confirms Sarah's position as the leader.

However, her responses are limited, and she is given little opportunity for discussion. For example, Sarah asks, "are you thinking that you're going to do that with them $\uparrow$ " (lines 910). This question leaves Tiffany with only two possible positioning options. She can say yes and maintain her position as a collaborative and compliant teacher, or she can say no and risk positioning herself as resistant. Tiffany says “ye:ah" (line 11) with enthusiasm, perhaps to assert her position as a good teacher who is willing to try what Sarah suggests.

In IU2, Sarah does not pause long enough during her explanation of what she thinks should happen during the lesson to give Tiffany an opportunity to contribute beyond "uh-huh" and "okay." When she does pause, she doesn't ask Tiffany what she thinks about the suggestions. Rather, she asks "does that make sense $\uparrow$ " Again, Tiffany responds with an enthusiastic “ye:ah.” In lines 57-66, their body language and Sarah's tone signal that videotaping is not a request. In line 58, Sarah says "and you can say no" but she uses a rising intonation, which indicates doubt about whether that is a viable option. Tiffany smiles in response to this statement in a way that seems to indicate that she knows she can't really say no. In line 57, Sarah nods yes as she says “but I'm wondering if you would want me to video tape this lesson" and she ends the statement with a downward intonation. In line 53, Sarah again asks a yes/no question that most likely makes it difficult for Tiffany to say no.

Despite the asymmetrical manner of the conversation, it is evident that Sarah simultaneously positions herself as a collaborative equal. For example, she presents all of her suggestions as something she is wondering (lines 5, 20, 53) and the first two suggestions as a "thought” (lines 7, 14). Based on Sarah's extensive knowledge about 
coaching techniques and her recent close attention to Johnston's (2004) Choice Words, it can be assumed that she is using these phrases intentionally because she understands that they have the potential to open up conversations and to help deemphasize the hierarchical relationship between the teacher and the learner. Thus, Sarah may be beginning her suggestions with "I'm wondering" (line 20) and "this is just a thought that I had" (line 21) in order to position herself as a collaborator. However, these phrases did not serve the purpose of opening up the conversation. Indeed, as indicated above, it seems that Sarah offered few opportunities for Tiffany to contribute. It may be that positioning herself as the collaborator gave her the power to continue as the leader in the interaction, giving directives while appearing to make suggestions. It could also be that Sarah is somewhat uncomfortable with her position as the expert leader and wants to think of herself (and for others to think of her) as a collaborative partner.

In IU5, Tiffany expresses trepidation about how the lesson might go. This emotionally laden portion of the interaction illustrates Tiffany's sense of vulnerability (Kelchtermans, 2005; Lasky, 2005) over whether or not she will be seen as a competent teacher during her evaluation. Based on post-video interview comments (Interview, 2/22/13), she is nervous because she knows that she will be evaluated by the principal during this lesson. She is also unsure about being able to do the lesson without Sarah's assistance. This fear is also seen in the second video segment when Tiffany says, "Oh no. Now it's going to be really bad" (lines 14 and 15). Sarah briefly acknowledges Tiffany's concerns in lines 79 and 81 of segment one saying, "I know," and smiling. However, she seems uncomfortable with Tiffany's expression of emotion. She leans away from Tiffany and throws her hand over her mouth around lines 77 and 78. She moves on to the next 
interactional unit ("well" and looking over text in lines 83-84), returning to the lesson planning before Tiffany is finished talking. The message seems to be that Tiffany's emotional concerns, which are based on her knowledge of her students and her experiences within the classroom, are not as relevant to the discussion as what the text says about the framework for lesson planning.

Sarah later indicated that "Tiffany does most things on her own" (Interview, 2/22/13). It could be that acknowledging Tiffany's concerns about doing the lesson on her own would conflict with Sarah's desire to position herself as a collaborative partner and Tiffany as independent and competent. This tension over Tiffany's independence as a competent literacy professional versus her dependency on Sarah's ongoing "support" is further displayed in the second video segment. When Tiffany implies that the lesson will not go as well if Sarah is not present (lines 14 and 15), she positions her as an essential part of the classroom. Sarah initially resists this position stating, "It's not going to be bad because you're doing the lesson anyway." (lines 16 and 17). She, thus, positions Tiffany as an independent professional, but then she immediately asserts the importance of her presence when she expresses distress at not being able to be there for the lesson (lines 2426). Sarah claims that it is important for her to evaluate the lesson. If she cannot be there "to see how it works out" (line 31), then it is essential that they obtain video of the lesson so that they "can talk about it" (line 48).

Common notions about what it means to be a new teacher seem to be at work within this interaction. For instance, within a stage model of teacher development novice teachers are assumed to be universally in survival mode and in need of help (Dall'Alba, \& Sandberg, 2006; Grossman, 1992). In interviews (Interview 10/24/12), Sarah 
acknowledged that Tiffany's performance did not fit in with common conceptions of a first year teacher. In interviews and informal conversations, she described Tiffany as an exceptional novice teacher who was adept at reflection and understanding the purposes of her instructional practices, yet in this interaction she did not discursively position Tiffany as a contributing equal. Rather, she reverted to explaining, giving directions, and "supporting." Interestingly, Sarah chose to share this video clip with her fellow coaches for feedback at a monthly coaches' meeting. They noticed Sarah's explanatory stance, critiqued the amount of time that Sarah talked, and suggested that she might ask Tiffany more questions. Sarah explained that she dominated the conversation because Tiffany was frustrated as a new teacher and needed extensive modeling (field notes, 12/8/13). This claim did not match Sarah's previous statements about Tiffany’s professionalism and competence. It seems that Sarah fell back on common assumptions about new teacher development in order to defend her coaching decisions within the interaction.

Furthermore, these assumptions influenced the ways she interacted with Tiffany in the moment despite her collaborative intentions and her respect for Tiffany's areas of expertise.

\section{Reflection Meeting with Luke}

This approximately five minute video segment comes from the end of a 30 minute coaching session between Sarah and Luke, a $2^{\text {nd }}$ year social studies and language arts teacher in $6^{\text {th }}$ and $7^{\text {th }}$ grades. They co-planned a unit for social studies in which the students worked in small groups to research a topic related to the effects of industrialization and present what they learned in three ways: a poster, a PowerPoint, and a paper. Sarah attended approximately ten out of fifteen class sessions devoted to this 
unit. Luke taught all of the mini lessons, and Sarah worked to support student learning through conferring.

In the following six-minute interaction, they are unhappy with how the students' products turned out and have been discussing what they might do differently next time to help the students be more successful. The video starts, in IU1, with Sarah and Luke discussing how they might change the rubric in order for the students to feel successful. In IU2, Luke refers back to an instructional plan that he discussed earlier in the video that he thinks will also help the students feel more successful. He plans to confer with each group to help them make connections between their research topics, and he has some questions printed out on papers sitting in front of him that he hopes will help "push their thinking" (Interview, 5/16/13). In IU3, Sarah talks about how she can support Luke when he tries this sort of work with his students again. In IU4a, Sarah talks about how doing some modeling for students might have helped them to be more successful. In IU5, Luke talks about how classroom management issues, like making sure the students are prepared could also help them to be more successful. In IU4b, Luke comes back to the idea of modeling for the students and suggests that it is harder to model for social studies projects than it is in writing workshop. Sarah explains how he might model in social studies, and then they wrap up their meeting.

\begin{tabular}{|c|c|c|c|}
\hline $\begin{array}{l}\text { Table } \\
\text { Trans }\end{array}$ & ript of $R$ & lection Meeting with Luke & \\
\hline Line & Speaker & Transcript & Contextualization Cues \\
\hline \multicolumn{4}{|c|}{$\begin{array}{l}\text { Interactional Unit 1: Luke and Sarah discuss how to grade students' performance based on the unit } \\
\text { rubric }\end{array}$} \\
\hline $\begin{array}{l}1 \\
2 \\
3\end{array}$ & Luke & $\begin{array}{l}\text { I do agree } \\
\text { like| you know } \\
\text { if no one made it over here }\end{array}$ & $\begin{array}{l}\text { Throughout most of this exchange, } \\
\text { Luke is leaning forward with his } \\
\text { elbow on the gable and the side of } \\
\text { his face resting on a fist. Line } 3 \text { : } \\
\text { Luke points to rubric with his pencil. }\end{array}$ \\
\hline
\end{tabular}




\begin{tabular}{|c|c|c|c|}
\hline 4 & Sarah & hmm.mm & \\
\hline $\begin{array}{l}5 \\
6\end{array}$ & Luke & $\begin{array}{l}\text { like | I'm not going to have them all fail } \\
\text { because obviously that's a reflection on }\end{array}$ & \\
\hline 7 & Sarah & hmm.mm & Sarah shaking her head no \\
\hline 8 & Luke & you know & \\
\hline $\begin{array}{c}9 \\
10 \\
11\end{array}$ & Sarah & $\begin{array}{l}\frac{\text { No }}{\text { and I think| I think we want| }} \\
\text { I think we want them to grow [from }\end{array}$ & \\
\hline 12 & Luke & right & \\
\hline $\begin{array}{l}13 \\
14 \\
15\end{array}$ & Sarah & $\begin{array}{l}\text { the ] experience } \\
\text { and we don't want } \\
\text { them to feel defeated }\end{array}$ & \\
\hline 16 & Luke & right & \\
\hline $\begin{array}{l}17 \\
18 \\
19 \\
20 \\
21 \\
22\end{array}$ & Sarah & $\begin{array}{l}\text { and so I think } \\
\text { as you and I are reflecting on it right now } \\
\text { we're seeing places where we feel like } \\
\text { we could've been more specific } \\
\text { we could've given them more direction } \\
\text { and fewer steps at one time }\end{array}$ & $\begin{array}{l}\text { Sarah pointing with her pen to the } \\
\text { notes that she has taken in her } \\
\text { notebook during the meeting. }\end{array}$ \\
\hline 23 & Luke & I agree & \\
\hline $\begin{array}{l}24 \\
25 \\
26\end{array}$ & Sarah & $\begin{array}{l}\text { And so I think } \\
\text { I think that by doing that }|\underline{\text { next }}| \text { time } \\
\text { Then } \mid \text { [you know }\end{array}$ & $\begin{array}{l}\text { Sarah runs her finger down the notes } \\
\text { in her notebook as she says "doing } \\
\text { that" }\end{array}$ \\
\hline 27 & Luke & it'll look better & \\
\hline 28 & Sarah & $\begin{array}{l}\text { The results ] are probably going to be more } \\
\text { positive }\end{array}$ & \\
\hline 29 & Luke & yeah & \\
\hline \multicolumn{4}{|c|}{ Interactional Unit 2: Luke shares his plans for future instruction } \\
\hline $\begin{array}{l}30 \\
31 \\
32 \\
\end{array}$ & Luke & $\begin{array}{l}\text { And even like practicing with this } \\
\text { like trying to write } \\
\text { to answer something }\end{array}$ & $\begin{array}{l}\text { Puts his hand on the papers that he } \\
\text { has laid on in front of him. }\end{array}$ \\
\hline 33 & Sarah & hmm.mm & Smiles and nods. \\
\hline $\begin{array}{l}34 \\
35\end{array}$ & Luke & $\begin{array}{l}\text { like| hopefully by doing these } \\
\text { and by like conferring about things like these }\end{array}$ & Points to papers with pencil. \\
\hline 36 & Sarah & yes & \\
\hline $\begin{array}{l}37 \\
38\end{array}$ & Luke & $\begin{array}{l}\text { they'll get used to\| journal like journaling } \\
\text { or like going longer about it }\end{array}$ & \\
\hline 39 & Sarah & hmm.mm & \\
\hline $\begin{array}{l}40 \\
41\end{array}$ & Luke & $\begin{array}{l}\text { so it's not just like| you know } \\
\text { like [to:o }\end{array}$ & \\
\hline 42 & Sarah & just like] here's the answer & $\begin{array}{l}\text { Motions with her hand in the air like } \\
\text { two times horizontally like she is } \\
\text { writing two lines of print. }\end{array}$ \\
\hline 43 & Luke & [yeah & \\
\hline 44 & Sarah & and I'm done] & \\
\hline 45 & Luke & [yeah. & \\
\hline 46 & Sarah & and moving like that] & \\
\hline \multicolumn{4}{|c|}{ Interactional Unit 3: Sarah offers Luke continued support } \\
\hline $\begin{array}{l}47 \\
48 \\
49 \\
50 \\
51\end{array}$ & Sarah & $\begin{array}{l}\text { well | it | it makes me | um } \\
\text { I'm | I'm glad to see that } \\
\text { you're not discouraged } \\
\text { in that you'd| you'd want to give up } \\
\text { and not try | again }\end{array}$ & $\begin{array}{l}\text { Gaze directed down } \\
\text { Hands outward towards Luke } \\
\text { Sarah raises gaze; Luke lowers gaze. } \\
\text { Luke's gaze down, smiling. }\end{array}$ \\
\hline
\end{tabular}




\begin{tabular}{|c|c|c|c|}
\hline $\begin{array}{l}52 \\
53\end{array}$ & Luke & $\begin{array}{l}\text { [no } \\
\text { I know for sure }\end{array}$ & \\
\hline 54 & Sarah & I mean | I don't think I'm hearing that ] & $\begin{array}{l}\text { Tilts her head down but keeps gaze } \\
\text { on Luke and smiles. }\end{array}$ \\
\hline $\begin{array}{l}55 \\
56 \\
57\end{array}$ & Luke & $\begin{array}{l}\text { no } \\
\text { I know for sure } \\
\text { we're trying again }\end{array}$ & $\begin{array}{l}\text { Continues looking down and } \\
\text { smiling. }\end{array}$ \\
\hline 58 & Sarah & okay & Smiles and nods her head. \\
\hline 59 & Luke & so & \\
\hline 60 & Sarah & okay good | good. & \\
\hline 61 & Luke & yeah & \\
\hline $\begin{array}{l}62 \\
63 \\
64 \\
65 \\
66 \\
67 \\
68 \\
69 \\
70\end{array}$ & Sarah & $\begin{array}{l}\text { and I } \mid \text { and I think } \\
\text { I agree | I agree with you on } \\
\text { um | everything that you were thinking about } \\
\text { because those are the things } \\
\text { that I was thinking about } \\
\text { and | um |again |I think } \mid \text { you know } \\
\text { if you | if you want my support } \\
\text { the next time } \uparrow \\
\text { I'm happy to give you that support again }\end{array}$ & $\begin{array}{l}\text { Sarah gazes down. Luke directs gaze } \\
\text { back to Sarah. }\end{array}$ \\
\hline 71 & Luke & yeah & \\
\hline \multicolumn{4}{|c|}{ Interactional Unit 4a: Sarah proposes lack of modeling as problem with unit } \\
\hline $\begin{array}{l}72 \\
73 \\
74 \\
75 \\
76 \\
77 \\
78 \\
79 \\
\end{array}$ & Sarah & $\begin{array}{l}\text { um land maybe } \\
\text { we can just take it step by step } \\
\text { and see } \\
\text { and maybe the types of projects } \\
\text { might need to change } \downarrow \\
\text { you know maybe we can think } \\
\text { about a different way of } \\
\text { *we can keep those same projects* }\end{array}$ & $\begin{array}{l}\text { Gesturing with her hands in an } \\
\text { explanatory manner as she speaks, } \\
\text { holding gaze with Luke. }\end{array}$ \\
\hline 80 & Luke & yeah & \\
\hline $\begin{array}{l}81 \\
82 \\
83\end{array}$ & Sarah & $\begin{array}{l}\text { um } \mid \text { but we may want } \\
\text { to try to bring in } \\
\text { um| some exemplar models } \uparrow\end{array}$ & \\
\hline 84 & Luke & yeah probably $\mid$ probably & \\
\hline $\begin{array}{l}85 \\
86 \\
87 \\
88 \\
89 \\
90 \\
91 \\
92\end{array}$ & Sarah & $\begin{array}{l}\text { maybe even making a poster } \\
\text { to share with them } \\
\text { and | um |I think || } \\
\text { you know | } \\
\text { and and I know that } \\
\text { and you | I mean | } \\
\text { we want to model } \\
\text { we want to show them examples }\end{array}$ & $\begin{array}{l}\text { Gestures one hand, palm up towards } \\
\text { Luke. } \\
\text { squints while shaking her head first } \\
\text { slightly "no" and then slightly "yes" } \\
\text { Uses explanatory gestures. Luke } \\
\text { nodding. }\end{array}$ \\
\hline 93 & Luke & yeah & \\
\hline $\begin{array}{l}94 \\
95 \\
\end{array}$ & Sarah & $\begin{array}{l}\text { and I think we had really *high hopes* } \\
\text { [and }\end{array}$ & $\begin{array}{l}\text { *higher tone, said quickly, raises her } \\
\text { hands up by her head* }\end{array}$ \\
\hline 96 & Luke & yeah & $\begin{array}{l}\text { Luke looks off to the side and up a } \\
\text { bit, like he's thinking. }\end{array}$ \\
\hline 97 & Sarah & we ] just $*$ jumped in* & $\begin{array}{l}\text { *said quickly and emphasized by } \\
\text { making two fists in the air in front of } \\
\text { her* }\end{array}$ \\
\hline 98 & Luke & yeah & \\
\hline
\end{tabular}




\begin{tabular}{|c|c|c|c|}
\hline $\begin{array}{c}99 \\
100 \\
\end{array}$ & & $\begin{array}{l}\text { I think so too } \\
\text { probably }\end{array}$ & \\
\hline $\begin{array}{l}101 \\
102\end{array}$ & Sarah & $\begin{array}{l}\text { and we probably needed to step back } \\
\text { just for a little bit }\end{array}$ & $\begin{array}{l}\text { Luke has a slight smile, still looking } \\
\text { off, and starts rocking side to side a } \\
\text { little bit in a jittery way. }\end{array}$ \\
\hline 103 & Luke & yeah & $\begin{array}{l}\text { Fiddles with rubrics on the table. } \\
\text { Sarah laughs and gazes down and } \\
\text { then back up again. }\end{array}$ \\
\hline \multicolumn{4}{|c|}{ Interactional Unit 5: Luke proposes students lack of preparation as problem with unit } \\
\hline $\begin{array}{l}104 \\
105 \\
106 \\
107 \\
108 \\
109\end{array}$ & Luke & $\begin{array}{l}\text { yeah } \\
\text { well and also it was like the projects } \\
\text { like the biggest thing I could see } \\
\text { with the projects } \\
\text { were | um | like maybe making sure like| } \\
\text { requiring them to get the materials } \\
\text { and have them there | like }\end{array}$ & $\begin{array}{l}\text { Luke briefly rubs his forehead and } \\
\text { then looks off to the side and up as } \\
\text { he talks. Sarah's gaze directed } \\
\text { intently at Luke with her hands } \\
\text { folded in front of her chest. } \\
\text { Luke gazes directly at Sarah. }\end{array}$ \\
\hline 110 & Sarah & hmm.mm & Nodding \\
\hline $\begin{array}{l}111 \\
112 \\
113 \\
\end{array}$ & Luke & $\begin{array}{l}\text { from like day one } \downarrow \text { like| } \\
\text { hey you guys need to have a poster board } \\
\text { by like | tomorrow } \downarrow\end{array}$ & \\
\hline 114 & Sarah & right & Nodding emphatically \\
\hline 115 & Luke & And not wait three weeks & \\
\hline 116 & Sarah & right & \\
\hline $\begin{array}{l}117 \\
118 \\
119 \\
120 \\
\end{array}$ & Luke & $\begin{array}{l}\text { and then be like } \\
\text { okay| well this week's poster week } \\
\text { so you guys need to start } \\
\text { and | you know }\end{array}$ & \\
\hline 121 & Sarah & hm.mm & \\
\hline \multicolumn{4}{|c|}{ IU4b: Further discussion of modeling: Is it the best strategy for this type of social studies project? } \\
\hline $\begin{array}{l}122 \\
123 \\
124 \\
125\end{array}$ & Luke & $\begin{array}{l}\text { but| I mean | I don't know } \\
\text { but yeah | I | I mean } \\
\text { modeling is easy in writing workshop } \\
\text { because you're all doing the same thing }\end{array}$ & Gazes to the side and up as he talks \\
\hline 126 & Sarah & hm.mm & \\
\hline $\begin{array}{l}127 \\
128 \\
\end{array}$ & Luke & $\begin{array}{l}\text { but it would be hard to like } \\
\text { model a PowerPoint and a poster and a paper }\end{array}$ & $\begin{array}{l}\text { Meets Sarah's gaze with the word } \\
\text { "poster" }\end{array}$ \\
\hline $\begin{array}{l}129 \\
130 \\
131 \\
132 \\
133 \\
134 \\
135 \\
136\end{array}$ & Sarah & $\begin{array}{l}\text { However } \\
\text { I think that | um | } \\
\text { we could pick *one topic } \uparrow * \\
\text { and show that one topic } \\
\text { in all three ways so that } \\
\text { this is how this would look as a poster } \\
\text { project } \\
\text { this is how it would look as a PowerPoint } \\
\text { and this is how it would look as a paper }\end{array}$ & $\begin{array}{l}\text { Sarah looks up from the corner of } \\
\text { her eyes likes she's thinking and } \\
\text { opens her mouth wide before saying } \\
\text { "however" }\end{array}$ \\
\hline 137 & Luke & || yeah & Tentative tone \\
\hline $\begin{array}{l}138 \\
139 \\
140 \\
141 \\
142 \\
143 \\
144 \\
145\end{array}$ & Sarah & $\begin{array}{l}\text { and | and that way they could see } \\
\text { that the same information's being presented } \\
\text { but it's being presented in three different ways } \\
\text { so we could show the paper } \\
\text { and this is the traditional way } \\
\text { of how we would write this paper } \\
\text { and have our own voice in there } \\
\text { and this is what we would write }\end{array}$ & $\begin{array}{l}\text { Luke meets Sarah's gaze. Nods } \\
\text { throughout her explanation. }\end{array}$ \\
\hline
\end{tabular}




\begin{tabular}{|c|c|c|c|}
\hline $\begin{array}{l}146 \\
147 \\
148\end{array}$ & & $\begin{array}{l}\text { if we were to put it up on a poster } \\
\text { you know I } \\
\text { it would be the same type of information }\end{array}$ & \\
\hline 149 & Luke & right & \\
\hline $\begin{array}{l}150 \\
151 \\
152 \\
153\end{array}$ & Sarah & $\begin{array}{l}\text { but we would present it written in this way } \\
\text { but we would add pictures and captions } \\
\text { and things to accentuate that } \\
\text { or a timeline }\end{array}$ & \\
\hline 154 & Luke & right & downward glance \\
\hline $\begin{array}{l}155 \\
156 \\
157 \\
158\end{array}$ & Sarah & $\begin{array}{l}\text { then we would move to the PowerPoint } \\
\text { where } \mid \text { they would see very } \underline{\text { minimal on }} \text { on the } \\
\text { screen } \\
\text { maybe like a picture and just bulleted points } \\
\text { but what we say }\end{array}$ & \\
\hline 159 & Luke & right & \\
\hline 160 & Sarah & would be the majority of it & \\
\hline 161 & Luke & yeah & \\
\hline $\begin{array}{l}162 \\
163\end{array}$ & Sarah & and that's probably what we should've [done & $\begin{array}{l}\text { Sarah tilts head way to one side. } \\
\text { Luke smiles. }\end{array}$ \\
\hline 164 & Luke & right & \\
\hline $\begin{array}{l}165 \\
166 \\
167 \\
168 \\
169 \\
170\end{array}$ & Sarah & $\begin{array}{l}\text { for ] *this project* } \\
\text { but | but I think } \\
\text { that we could still do that for the next time } \\
\text { and just | you know | like I said | } \\
\text { pick one topic } \\
\text { and show it in those three different ways }\end{array}$ & $\begin{array}{l}\text { *higher pitch with slight rising } \\
\text { intonation and smile* }\end{array}$ \\
\hline 171 & Luke & yeah & \\
\hline 172 & Sarah & || does that sound okay $\uparrow$ & \\
\hline $\begin{array}{l}173 \\
174\end{array}$ & Luke & $\begin{array}{l}\text { No yeah } \\
* \text { I agree* }\end{array}$ & $\begin{array}{l}\text { Looks down at paper. } \\
\text { *said with tentative tone* }\end{array}$ \\
\hline 175 & Sarah & okay $\mid$ so $\mid$ all right & $\begin{array}{l}\text { Looks at me, like she's indicated that } \\
\text { they are finished. }\end{array}$ \\
\hline
\end{tabular}

In terms of content, this interaction is primarily an evaluation, or "reflection"

(lines 6 and 18), of the social studies unit for the purpose of planning for the "next time" (lines 25 and 167). It also serves as a debate about the effectiveness of modeling as a best practice (IU4a and $4 \mathrm{~b}$ ) and as a negotiation about whether or not Luke needs continued coaching support (IU3).

There are several tensions associated with the evaluation of the unit. First, there is a tension concerning whether to focus on product or process. A focus on product concerns the students' final projects. A focus on process concerns both the students' 
process of creating their products and the teachers' (Sarah and Luke) instructional process of facilitating students' progress and learning. They focused on process for the first half of the meeting but shifted to discussing product around minute sixteen when Sarah asked, "Do you feel that you are going to have students that actually do well on their projects based on the rubrics?" Focus on the final product is evident in IU1 in which they discuss the rubric and how "the results are probably going to be more positive" (line 28) if she and Luke are "more specific" (line 20) next time. They continue this focus in IU4a and $4 \mathrm{~b}$ when Sarah argues for the importance of providing "exemplar models" (line 83) of the final products.

Luke felt that this focus on the product led to an unfairly negative view of the unit, the students' learning, and his teaching. When I asked if he agreed with Sarah that modeling for the students would have been helpful, he answered,

I felt like she was being a little bit more negative or maybe just even focusing more on what didn't work as opposed to what did work. I mean, like things they did that were positive and beneficial to them as opposed to things that maybe we could have done differently. And I don't think we ever really have had that conversation where we sat down and discussed that maybe their projects didn't turn out the way we wanted, but what through the process, did we like. (Interview, 5/16/13)

This tension over product versus process concerns a larger ideological debate about the loci of knowledge and power, similar to the one highlighted in Nina's small story. Process is only visible within the classroom through direct observation of and interaction with students. The final product can be viewed outside of the classroom, isolated from practical experience and evaluated against external evaluative measures. 
When process is emphasized, the teacher's practical knowledge, based on classroom experiences and relationships with students, has more weight.

A closely related tension concerns where to place the blame for what went wrong in the unit and what the next steps should be. Luke first focuses, In IU2, on offering more support to students by reteaching in small groups. He argues that "hopefully by doing these [questions in small groups]" (line 35) the students will be able to extend their thinking and their writing. He asserts an identity as a competent professional by coming to the meeting with next steps planned and by emphasizing his knowledge of and compliance with best practices such as "conferring" (line 35) and "journaling" (line 37). He tactically uses the vocabulary, "the received language," of best practices and "transforms it into a song of resistance" (de Certeau, 1984, p. 18).

Sarah, however, ignores Luke's' suggestions thereby rejecting his attempt to assert an identity as a competent teacher. Instead, she claims that the problem with the unit was their failure to properly model for students and that the next step should be to "pick one topic and show it in those three different ways" (lines 169-170). Luke constructs two responses to this claim. First, he proposes that the students' lack of preparation may have been "the biggest thing" (line 106) that prevented the students' successful completion of the projects. This argument emphasizes student responsibility and removes some of the blame from him. Secondly, he argues that modeling may not be the best instructional strategy for this case saying, "Modeling is easy in writing workshop because you're all doing the same thing, but it would be hard to like model a PowerPoint and a poster and a paper" (lines 124-128). With this critique, he distances himself from any blame for not having modeled in the first place. 
This critique also brings into question whether modeling is a universal best practice or a contextually specific practice that works well in some instances but may not be the best instructional choice in every situation. Sarah positions herself in opposition to this critique and firmly asserts that modeling is a universal best practice. With emphasis on the conjunction "however" (line 129), Sarah announces her explanatory power as the more knowledgeable other and dominates the remainder of the discussion. Luke accepts her position, confirming Sarah's viewpoint with "yeah" or "right" and frequent nodding. But, this acceptance is reluctant as evidenced by his long pause and tentative tone in lines 137 and 174 and downward glances in lines 154 and 173. His disagreement is further evidenced in the fact that he did not institute modeling the next time he tried a projectbased unit, nor did he invite Sarah to try it with him (Interview, 5/16/13). This tension reflects ideologies about what counts as valuable knowledge as they negotiate what is most important for effective instruction: expert knowledge of best practices or contentspecific pedagogical knowledge.

Another tension within this interaction involves the emotional rules (Zembylas, 2005a) surrounding the offer and acceptance of "that support" (line 70) from the coach. In IU3, Sarah attributes negative emotions and instructional weakness to Luke when she states in lines 48-51, "I'm glad to see that you're not discouraged in that you'd want to give up and not try again." She implies that Luke has failed and, therefore, has reason to be discouraged and is in need of her continued support. She uses similar language when talking about the students when she says, "we don't want them to feel defeated" (lines 14-15). She seems to be positioning herself within Discourses of nurturing and developmental scaffolding and, conversely, positioning both Luke and his students as 
dependent on her support as they try out new skills and practices. Luke resists this position by asserting that "I know for sure we're trying again" (lines 53, 56, and 57). His resistance is further emphasized by a gaze directed down and away from Sarah, a playful tone, and a half smile that seems to express the absurdity of assuming that he would give up.

While Sarah uses the second person pronoun, you, to attribute negative emotions such as discouragement to Luke and his students, she uses the collective pronoun, we, to express positive emotions as in "we had really high hopes" (line 94). As such, Sarah presents herself as a positive person and as someone who does not need support. Furthermore, she implicitly establishes that positive displays of emotion are acceptable within the learning community but negative ones are not. Within this emotion talk, Sarah is working to maintain her identity as a competent and nurturing coach who has no reason to be discouraged and can be trusted to know what she is talking about. As she stated later, "I felt bad because it was something that I had encouraged Luke to try" (Interview 4/9/13). Her identity as a more knowledgeable other is at stake because something that she suggested did not work out well. She does not, however, express her discouragement in this interaction. Instead, she projects her own feelings of discouragement onto Luke, perhaps to decrease the threat to her credibility as a coach.

The emotion talk in IU3 highlights the vulnerability that both Luke and Sarah feel within their collaborative work. Luke and Sarah brought up this vulnerability later in a paired interview (Interview, 4/9/13). Luke spoke of the importance of "being open and honest and not being defensive and closed.” He said, "Why hide mistakes? ... I know I'm not perfect, but I try my best and that's all you can do." Sarah elaborated, "If you [a new 
teacher] show that you're making mistakes, sometimes that's scary because you think, okay there are things that I really suck at, and I might lose my job." Despite his claim that he is open to making mistakes, Luke takes steps throughout the video-recorded interaction to decrease his vulnerability. For instance, he does not use the "we" pronoun as Sarah does frequently throughout the interaction. As such, he asserts himself as the teacher responsible for the classroom and as nondependent on Sarah's support. Additionally, he aligns himself with best practices when it helps to make him less vulnerable (for example, in IU2) even though he questions the practice of modeling and its merits more generally.

Sarah and Luke navigate all of these tensions with discursive moves that construct a sense of collaborative agreement. For instance, Luke positions himself as easy to get along with and willing to try new things in the classroom and as compliant with best practices such as conferring, modeling, and journaling (IU2). When Luke does voice resistance, he couches his objections with phrases that indicate agreement. Although he hedges at times with words like "probably" (lines 84 and 100), he frequently confirms Sarah's comments with, "I agree" (lines 1, 23, and 174). Sarah also takes care to position herself as agreeable and collaborative. She hedges with the use of elaborate embedded clauses in lines 62-70 when she offers her continued support and again with words like "maybe" in lines 72 and 85. Furthermore, she maintains eye contact with Luke for the majority of the interaction, nods, and uses backchannels such as "hm.mm" and "right" to indicate that she is listening intently. Although she ultimately makes a unilateral decision about modeling as the most appropriate next step, she appears to include Luke in the decision making by offering a false choice in line 172, "Does that sound okay?" Clearly, 
Luke is positioned in a manner that would make it difficult for him to do anything but agree with Sarah. They seem to work very hard to maintain the aura of collaboration, but in the end, they have made little progress in resolving any of the tensions present in the interaction.

\section{Summary}

The ways in which Sarah and the teachers positioned themselves and one another in these interactions were heavily influenced by Discourses of best practice and teacher development, their need to maintain credibility, and their local norms for collaboration. Sarah aligned herself with the local best practices that are associated with the workshop model; worked to transfer knowledge of instructional techniques such as conferring, journaling, and modeling; and actively encouraged teachers to implement those practices. The teachers also aligned themselves with best practices in order to be seen as competent professionals who are compliant with the district's instructional initiatives. They simultaneously resisted the Discourse of best practices when it conflicted with their local, contextual knowledge based on daily, lived experience.

Furthermore, Sarah and the teachers were limited by Discourses of professional development and of development in a more general sense. For instance, their ideas about what it means to be a novice or veteran teacher, based on a stage model of professional development, influenced how they positioned one another. The heavy emphasis on best practices led to an understanding of teacher development as a progression along a continuum of implementation and fidelity to workshop methods. Their interactions were also influenced by prominent Vygotskian views of child development. For instance, 
Sarah was positioned as "the more knowledgeable other" (Vygotsky, 1978), and the teachers were positioned as deficient and in need of support.

Both Sarah and the teachers worked to establish and maintain their professional and relational credibility within a topography of vulnerability (Kelchtermans, 2005; Lasky; 2005) in which they felt that they needed to save face and avoid shame (Day \& Qing, 2009; Goffman, 1967). They established professional credibility through their professed alignment with best practices, and they established relational credibility through their efforts to conform to norms of collaboration. Sarah and the teachers appeared to value getting along and avoiding conflict over resolving disagreements and coming to a consensus. In these interactions, Sarah and the teachers worked so hard to agree with one another that the central tensions of their discussions were obscured. As such, the interactions were more about reducing feelings of vulnerability by asserting identities of competency and collaboration than they were about co-constructing a shared vision for instructional practice.

All of these positionings highlight how, despite best intentions, collaboration and professional learning were limited by powerful ideologies of best practices and development and by the traditional structures of schools and institutions, which devalue teachers' practical and emotional knowledge. However, they also highlight how coaches and teachers worked to resist these limiting Discourses, to appropriate best practices for their own purposes, to co-construct agentive identities as competent professionals, and to build collaborative relationships in the cracks of the institution (de Certeau, 1984). I will return to these issues of identity, power, and positioning again in chapter seven, but for 
now I turn to Westfield School to examine the complex positionings enacted by Grace, Katie, and Sophie. 


\section{CHAPTER VI}

\section{COACHING INTERCTIONS AT WESTFIELD PRIMARY SCHOOL}

At the time of this study, Grace had been at a literacy coach at Westfield School for three years. Like Sarah, Grace is a highly respected leader with a great deal of credibility based on a combination of expertise and trust. Her colleagues considered her to be highly knowledgeable in reading and writing workshop methods. As her principal, Donna, explained, "She's the expert. She's had, you know, years and years of training” (Interview, 10/24/12). The teachers trusted her not to evaluate them. Katie shared, "She was not judgmental to me. She was just very, like, calm and listened and would ask questions to me...but she kind of just led me to turn my thinking around without telling me I was wrong” (Interview 12/3/12).

Grace's daily work included literacy coaching in a variety of forms as well as other tasks. She held grade-level "coaching sessions” every Friday during the school day that lasted approximately 45 minutes to an hour in which she shared resources for reading, writing, or math workshop. These sessions, which both Grace and her principal considered to be a key part of her coaching role, were basically mini-workshops in which she shared "ideas" to help teachers "get their students further in workshop" (Grace, Interview, 10/17/12). She was also an official mentor for the two "brand new teachers" in her building with whom she "touched base" frequently, "went in [their classrooms] and modeled a framework... showed them how to differentiate... and helped them get the 
structures down" (Grace, Interview, 10/17/12). These coaching tasks aligned with a technical modeling of coaching (Joyce \&Showers, 1980) in that they were formalized, routine, and focused on transmitting knowledge of techniques.

In addition to coaching sessions and mentoring, she met informally with teachers at their initiative, often before or after school. She explained,

"I think they see me as a person for resources, you know, if they need those. I've had several come and ask. I don't think they're at the point of seeing, a lot of them are not at the point of seeming me as like that co-teacher, co-collaborator, planner that could help in that fashion.” (Interview, 10/17/12)

As Katie explained, Grace wears "many different hats" in her role (Interview, 12/3/12). She performed many daily tasks that are often associated with a literacy coach's job (Bean et al., 2010; Duessen et al., 2007). These included analyzing data, organizing interventions, leading problem-solving meetings, and providing daily interventions to small groups of students in reading, writing, and math.

Grace's personal goal as a literacy coach was to help "others to fulfill their potential" and "discover knowledge." She described coaching as "a job that, I guess, maybe defines their potential for them or helps them to discover that potential" (Interview 5/12/13). The teachers felt that Grace was successful in this goal. Katie shared, "I have some of that background knowledge that she has helped me develop" (Interview, 12/3/12). Similarly, Sophie explained how Grace helped her become more knowledgeable of workshop methods. She said, "She has all the resources and different ideas and what she's had success with, so that's helped" (Interview, 12/1012). The Discourse of best practices is apparent in these descriptions of coaching. However, the 
following interactions highlight how it was complicated as Grace, Katie, and Sophie negotiated what counts as relevant knowledge and what professional development means.

\section{Conversation with Katie}

Katie is a veteran teacher in her late thirties with sixteen years of experience teaching primary grades at Westfield Elementary School. Katie has been implementing reading and writing workshop in her $2^{\text {nd }}$ grade classroom for several years, and attributed much of her progress to Grace's support through coaching. She volunteered her classroom to be the lab classroom when Grace was training to be a literacy coach. During that year, Grace practiced doing coaching cycles with Katie and frequently worked in her classroom. Since then, Katie and Grace have become close friends and chat on a regular basis. These chats often include discussions that Grace considers to be informal coaching interactions, but they have not done any formal coaching cycles together since Grace's first year in the building.

Grace videotaped one of their after school chats, an approximately ten-minute event that was initiated by Katie and occurred in her classroom. In the first four minutes of the interaction, Katie expressed a concern that her students were not discussing new reading strategies during share time in readers workshop. Grace suggested that Katie should encourage students to use new strategies and tools during reading conferences conducted during independent reading time. The middle portion of the coaching event, from which the following transcript is taken (See Table 6.1), consisted of approximately five minutes in which Katie shared a small story about what usually occurs during her reading workshop. Grace interjected with explanations about proper workshop procedures. In the final minutes of the conversation, they summarized their discussion 
and outlined next steps, which included Grace observing students for time on task and Katie's organizing for more purposeful conferences.

The portion of the coaching event recorded in the following micro-transcript (See Table 6.1) consists of two simultaneously occurring conversational threads that are only loosely related to one another. The first conversational thread is Katie's self-initiated small story about what she does in her classroom during reading workshop, what problems she has encountered that prevent her from conferring with students, and possible solutions. The second conversational thread consists of Grace's interjections in which she gives Katie directions and brief explanations concerning procedural aspects of conferring and share time.

In IU1, Katie sets her small story in her classroom "over here at the guided reading table" (line 2) and "out" (line 11) with the students as they read independently. She then explains that she has trouble finding time for conferring because of her instructional priorities and a tight schedule. She suggests that one solution might be to have students work independently for a portion of their guided reading lesson so that she can confer with other students. In IU3, she explains her problem of conferring with the same students and suggests that she needs to "be more purposeful in her note taking" (Lines 74-75) so that she can "make sure I'm picking everyone" (Line 76). Next, she explains scheduling issues that make it difficult to find time for conferring and considers the possibility of adjusting the workshop schedule (IU5). In IU7, she offers an evaluation of the proposed solutions, suggesting that they will help to improve share time. Finally, she presents a coda to her story in which she reiterates her frustrations and hopes concerning share time (IU9). 
Grace interjects throughout Katie's small story with instructions about how to "be intentional" (lines 106. 110, 126, 128, and 179) about conferring with students. In IU2, she suggests that Katie needs a routine for scheduling conferences. She asks, in IU3, if Katie has "a tracking sheet" (line 80) for documenting when and with whom she has conferred. In IU5, Grace insists that routines and documentation are necessary to be intentional about conferring with students, and in IU8, she reiterates the importance of being "intentional about setting it up" (line 179).

Although Grace's interjections are somewhat related to Katie's previous interactional units, they do not directly address Katie's proposed problems and solutions. Vice versa, Katie incorporates elements from Grace's talk into her small story, yet her story maintains cohesion even if the interactional units initiated by Grace are removed. In essence, they are involved in parallel monologues rather than in meaningfully interactive dialogue. They appear to be having a two-way conversation, but are in actuality talking at each other, and they have separate purposes for their communication. As I highlight below, Katie's small story serves to focus the conversation on teacher knowledge situated within classroom experiences and to present an identity as a reflective, competent, compliant teacher. Grace, on the other hand, focuses the conversation on best practices for reading workshop and simultaneously positions herself as a collaborative equal and a more knowledgeable expert. The interaction is essentially about what Katie should be doing during reading workshop, whether or not she has lived up to those expectations in the past, and how she will do better in the future. 


\begin{tabular}{|c|c|c|c|}
\hline \multicolumn{4}{|c|}{ Table 6.1} \\
\hline \multicolumn{4}{|c|}{$\begin{array}{l}\text { IU1: Katie's Small Story } \\
\text { Problem/solution } 1\end{array}$} \\
\hline Line & Speaker & Transcription & Contextualization Cues \\
\hline $\begin{array}{l}1 \\
2 \\
3 \\
4 \\
5 \\
6 \\
7 \\
8 \\
9 \\
10 \\
11 \\
12 \\
13 \\
14\end{array}$ & Katie & $\begin{array}{l}\text { I love what I'm doing } \\
\text { over here at the guided reading table } \\
\text { and I know | } \\
\text { that it's worthwhile and beneficial } \\
\text { so then I just get anxious } \\
\text { to get my next group in } \\
\text { because I'm watching the clock } \\
\text { and I need to get better at | um || } \\
\text { giving them | } \\
\text { a little bit of independent time over here } \\
\text { then going out } \\
\text { instead of just staying here with them | } \\
\text { the whole time } \\
\text { so }\end{array}$ & \\
\hline \multicolumn{4}{|c|}{$\begin{array}{l}\text { IU2: Grace's Directions } \\
\text { "You need a routine schedule for conferring" }\end{array}$} \\
\hline $\begin{array}{l}15 \\
16 \\
17 \\
18 \\
19 \\
20 \\
21 \\
22 \\
23 \\
24 \\
25 \\
26 \\
27 \\
28 \\
29\end{array}$ & Grace & $\begin{array}{l}\text { sure } \\
\text { well I think } \\
\text { that allows you some conferring time } \\
\text { and teachers do that all different ways } \\
\text { some teachers do what you're saying } \\
\text { get this group started here } \\
\text { give them something } \\
\text { and then bop out there } \\
\text { do a conference } \\
\text { some people say } \\
\text { I'm going to do three conferences a day } \\
\text { and there's going to be one } \\
\text { at the beginning of workshop } \\
\text { one at the end } \\
\text { one in between my guided reading groups }\end{array}$ & \\
\hline 30 & Katie & right $\downarrow$ & \\
\hline $\begin{array}{l}31 \\
32 \\
33 \\
34\end{array}$ & Grace & $\begin{array}{l}\text { I've seen teachers } \\
\text { even take like Monday through Thursday } \downarrow \\
\text { do guided reading groups } \downarrow \\
\text { and then they spend all Friday conferring } \downarrow\end{array}$ & \\
\hline 35 & Katie & right $\downarrow$ & \\
\hline 36 & Grace & that kind of thing $\downarrow$ & \\
\hline $\begin{array}{l}37 \\
38 \\
39 \\
40 \\
41\end{array}$ & Grace & $\begin{array}{l}\text { so } \mid \text { I think } \\
\text { whatever system you use } \\
\text { but I think } \\
\text { it is important to think through } \\
\text { how many conferences are you doing } \uparrow\end{array}$ & \\
\hline 42 & Katie & right $\downarrow$ & \\
\hline 43 & Grace & in a week's time & \\
\hline 44 & Katie & making sure & \\
\hline $\begin{array}{l}45 \\
46\end{array}$ & Grace & $\begin{array}{l}\text { um | you probably } \\
\text { you know }\end{array}$ & \\
\hline
\end{tabular}




\begin{tabular}{|c|c|c|c|}
\hline 47 & & how many kids do you have $\uparrow$ & \\
\hline 48 & Katie & 23 & \\
\hline $\begin{array}{l}49 \\
50\end{array}$ & Grace & $\begin{array}{l}\text { so you're probably looking at } 2 \text { to } 2 / 12 \text { weeks } \\
\text { *reali:stically* }\end{array}$ & $*_{\text {in a sing-song tone }}$ \\
\hline 51 & Katie & $\overline{\text { right } \downarrow \text { yeah }}$ & \\
\hline $\begin{array}{l}52 \\
53 \\
54 \\
55 \\
56 \\
57\end{array}$ & Grace & $\begin{array}{l}\text { of touching base } \\
\text { with each person } \\
\text { I mean } \\
\text { I know when you read } \\
\text { some of the blogs and books } \\
\text { they'll say conference we:ekly }\end{array}$ & \\
\hline 58 & Katie & right $\downarrow$ & \\
\hline $\begin{array}{l}59 \\
60 \\
61\end{array}$ & Grace & $\begin{array}{l}\text { I personally never found that || } \\
\text { realistically } \\
\text { you know }\end{array}$ & \\
\hline \multicolumn{4}{|c|}{$\begin{array}{l}\text { IU3: Katie's Small Story continued } \\
\text { Problem/Solution } 2\end{array}$} \\
\hline $\begin{array}{l}62 \\
63 \\
64 \\
65 \\
66 \\
67 \\
68 \\
69 \\
70 \\
71 \\
72 \\
73 \\
74 \\
75 \\
76\end{array}$ & Katie & $\begin{array}{l}\text { well } \\
\text { and I find myself } \\
\text { going to the same kids } \\
\text { either the struggling learners } \\
\text { or I find myself } \\
\text { going to the ones who are a little off task } \\
\text { instead of } \\
\text { you know } \\
\text { the high readers } \\
\text { or the whatever } \\
\text { like 'cause I | } \\
\text { I find myself } \\
\text { and I need to be more | um || } \\
\text { purposeful in my note taking } \\
\text { and making sure I'm picking everybody }\end{array}$ & \\
\hline \multicolumn{4}{|c|}{$\begin{array}{l}\text { IU4: Grace's Directions } \\
\text { You need to document who you have conferred with }\end{array}$} \\
\hline $\begin{array}{l}77 \\
78\end{array}$ & Grace & $\begin{array}{l}\text { I was going to say } \\
\text { do you have like a class grid } \uparrow\end{array}$ & \\
\hline 79 & Katie & I d:o^ & \\
\hline $\begin{array}{l}80 \\
81\end{array}$ & Grace & $\begin{array}{l}\text { or tracking sheet } \\
\text { that you could do } \uparrow\end{array}$ & \\
\hline $\begin{array}{l}82 \\
83\end{array}$ & Katie & $\begin{array}{l}\text { I d:o } \uparrow \\
* I t ' s \text { on that pink clipboard }\end{array}$ & said in a higher, softer tone \\
\hline 84 & & & $\begin{array}{l}\text { (timid) } \\
\text { laughs between lines } 83 \& \\
84\end{array}$ \\
\hline $\begin{array}{l}85 \\
86\end{array}$ & Grace & $\begin{array}{l}\text { *it's okay* } \\
\text { that's being honest }\end{array}$ & rising tone (comforting) \\
\hline 87 & Katie & I know & \\
\hline \multicolumn{4}{|c|}{$\begin{array}{c}\text { IU5: Katie's Small Story Cont. } \\
\text { Problem/solution } 3\end{array}$} \\
\hline $\begin{array}{l}88 \\
89 \\
90 \\
91 \\
92 \\
\end{array}$ & Katie & $\begin{array}{l}\text { well | and } \\
\text { I | have kids leave for interventions right at 1:00 } \\
\text { so I like the idea of like } \\
\text { before my groups start } \\
\text { so then I could }\end{array}$ & \\
\hline
\end{tabular}




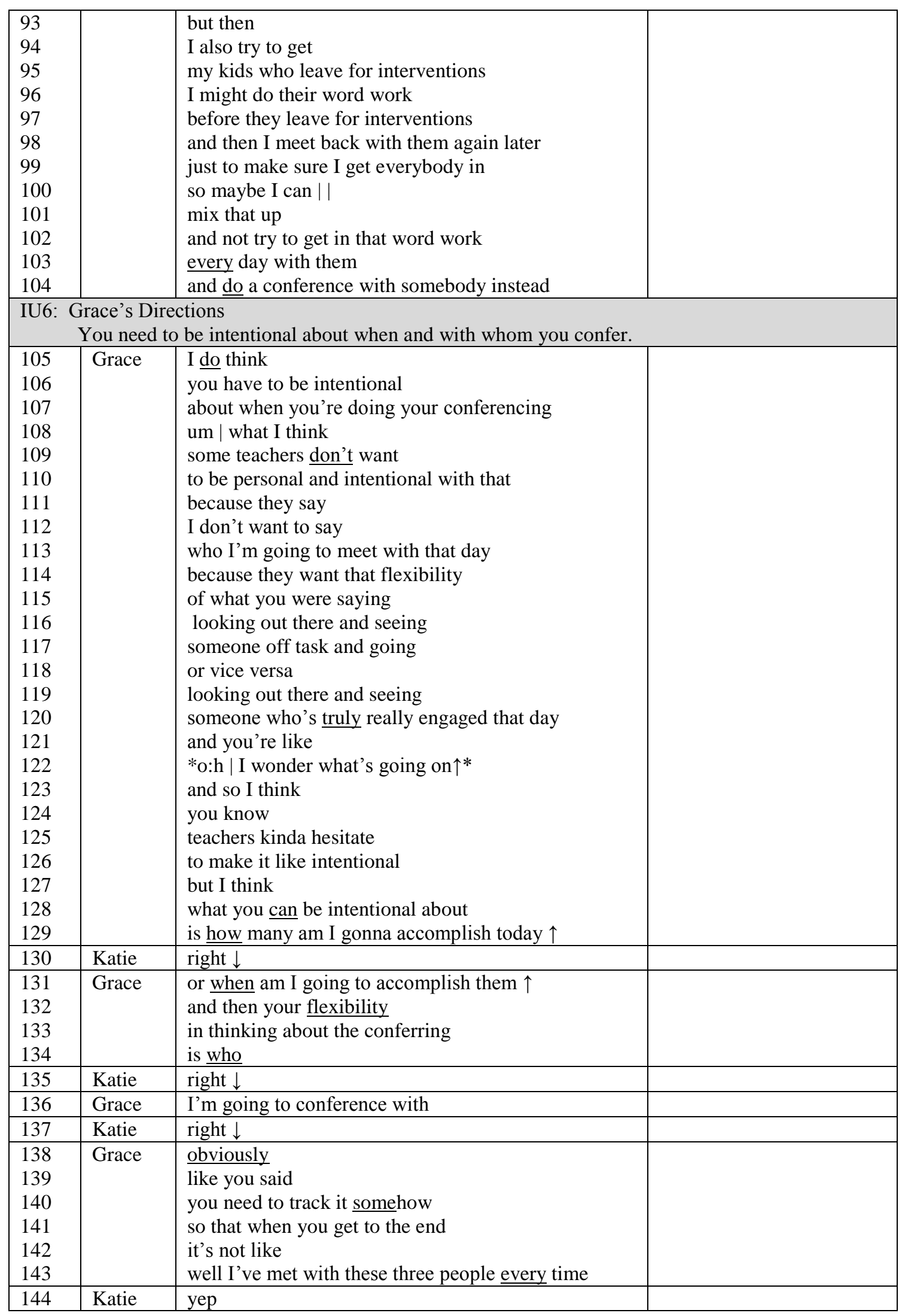




\begin{tabular}{|l|l|l|}
\hline 192 & & it's just \\
193 & we get together & \\
194 & and they're like & \\
195 & oh, I did this & \\
197 & and I'm like & \\
198 & argh, how many times & \\
199 & are we going to see a character trait card $\uparrow$ & \\
200 & or how many times & \\
201 & are we going to see that $\uparrow$ & \\
202 & I think it will \\
203 & raise the level of expectation for them & \\
204 & raise the level of what they're sharing & \\
\hline
\end{tabular}

In this interaction, Grace and Katie have agreed that more attention to conferring with students may help to improve share time. It is apparent, however, that they have different ideas about which information is most relevant for deciding on next steps. Katie focuses primarily on personal experiences in her own classroom, her feelings about her instruction, her in-the-moment decision making, and the details of her schedule. In contrast, Grace focuses on the appropriate procedures for conferring and share time and what she has observed outside of Katie's classroom.

This tension over relevancy is highlighted by Katie's word choices for initiating her turns of talk. In interaction units 3, 5, and 7, she begins her turn with the discourse marker "well” (lines 61, 88, and 152). As Jucker (1993) explained, "In a conversation, the relevant context is continually being negotiated" (p. 450), and well is often used to "indicate a shift in the relevant context" (p. 451). Katie uses well to reframe the conversation to include a different set of background assumptions. Namely, she reorients the conversation from a focus on procedures and outside experts to a focus on her own reflections of her classroom practice, consistently shifting the conversation back to her small story. For instance, in line 61, she says "well” to shift from Grace's focus on methods for scheduling weekly conferences to a focus on what she finds herself (lines 63, 
$66,73)$ doing in the classroom. She makes a similar shift in line 88 when she moves the conversation from a discussion about whether or not she has been documenting her conferences to a story about what she does with her students who leave for interventions during reading workshop. In IU7, she reframes Grace's explanation of how to be intentional about scheduling conferences back to her original concern about share time.

These moves illustrate the tension over what counts as relevant knowledge for instructional decision making. For instance, Katie draws on emotional understandings of what happens in her classroom. She says, "I love what I'm doing over here at the guided reading table" (lines 1-2)..."I just get anxious to get my next group in" (lines 5-6). In these lines, she uses emotional expression to explain her instructional priorities and to justify the decisions she has made during readers workshop. In IU9, she expresses frustration about what happens during share time, saying, "I'm like argh..." (lines 196197). When she states, "because I feel right now..." (line 191), she indicates that her emotional interpretations of current classroom experiences are an impetus for changing her practice. Grace, on the other hand, does not use emotional expressions as a basis for decision making but focuses instead on explanations of possible procedures for scheduling conferences and for being "intentional." Emotional ways of knowing are counted as less salient than procedural knowledge of best practices (Hargreaves, 2001; Hunt \& Handsfield, 2013; Zembylas, 2005a, 2005b).

Katie also draws on recent classroom experience and the details of her daily practice as relevant context for the discussion. For example, in IU3, she focuses on the details of the intervention schedule and how it affects her decisions about when and with whom she will confer. Grace attempts to position herself similarly in relation to 
classroom experience, perhaps because she realizes that the classroom context is valuable to Katie. In IU2, Grace tells stories about unidentified, and possibly imaginary, teachers as a way to suggest different ways of scheduling conferences (lines 18-34), and she mentions her previous classroom experience (lines 59-60). She also draws on resources such as "blogs and books" (line 56) but dismisses them based on her past teaching experience (lines 59-60). They are both drawing on classroom experience, but Katie's experience is real and recent while Grace's is depersonalized and distant. Thus, Grace is limited in her ability to align herself with practical classroom knowledge and experience even though she recognizes the relational value of positioning herself within the classroom.

Although Grace recognizes classroom experience as relevant content, she primarily focuses on the procedural aspects of conferring and share time. Her arguments encourage the correct way of implementing best practices for reading workshop. In IU2, she asserts the position that a teacher must have a "system" (line 38) for planning "how many conferences" (line 41) they are going to do each day. In IU4, she promotes the use of a "class grid" (line 78) or "tracking sheet" (line 80) for documenting conferences. In IU6, she argues that such planning and documentation is a necessary elemental of being "purposeful and intentional" (line 110) about instructional decisions made during reading workshop. While these are sensible suggestions, they devalue Katie's practical, in-themoment decision making in favor of a system for implementation and documentation. Grace implies that since Katie has not been using such a system she has failed to teach with intention and purpose. Furthermore, Grace presents best practices as the essential element of successful instruction. In line 177, she states, "that share time is just another 
opportunity to teach." She constructs share time as the active subject. Thus, it is the best practice that has the power to transform teaching and learning, and Katie's power only comes through the appropriate use of such strategies and tools.

Grace repeatedly claims that Katie needs to be more intentional about scheduling and documenting conferences, and she uses discursive tactics in order to make her argument more palatable. For example, she simultaneously positions herself as an authoritative expert and an unimposing colleague. One way she achieves this simultaneous positioning is with a tactical use of the phrase I think (lines 16, 39, 105, $108,123,127)$. This phrase, referred to as a comment clause (Kaltenböck, 2009) or modal expression (Aijmer, 1997; Facchinetti \& Adami, 2008), often indicates uncertainty and softens the force of a statement (Coates, 1983; Dehè \& Wichmann, 2010). As such, Grace's frequent use of the phrase helps to position her as non-authoritative. However, since Grace uses I think in the initial clause and with level stress, it may also serve as a "means of expressing emphasis and confidence" (Holmes, 1990, p. 187). Additionally, it could be a way to support her arguments with her own authority and expertise, which is highly respected by Katie (Katie, Interviews, $12 / 3 \& 5 / 23$; Grace, Interview, 5/21).

Grace further achieves this simultaneous positioning by presenting her directives and explanations as suggestions and by distancing herself from her claims. For instance, in IU2, Grace could have simply listed out the options for scheduling conferences, but instead she shared observations of other teachers. By doing so, she makes it seem that she is suggesting possibilities rather than insisting that Katie employ a system for scheduling conferences. She uses a similar tactic in IU6 when she says, "some teachers don't want to be purposeful and intentional" (lines 109-110). She creates a faceless group of teachers to 
criticize because she may not want to directly criticize Katie for being unintentional. Although she attempts to avoid an authoritative stance, Grace nevertheless positions herself as the expert who transmits knowledge about best practices.

In some ways, Katie resists her role as the passive recipient of knowledge. She tells stories about what has occurred in her classroom and what her hopes are for the future. These stories challenge the Discourse of best practices because they account for diverse ways of knowing. On a discursive level, she challenges Grace's expertise and authority by initiating turns of talk in ways that make it possible for her to regain the floor and continue her small story. Yet, she accepts the passive role during Grace's turns of talk, acknowledging her comments with "right" (lines 30, 35, 42, 51, 58, 130, 135, $137,150,163,180,187,190)$ and "yep" (lines 144 and 175).

Katie is not in the position to explain. Rather, she is in the position to judge herself in relation to best practices, or what should be done as outlined by Grace and the professional learning community. Each time she presents a problem, she is explaining why she has not lived up to the expectations of best practice, and each solution she shares is a pledge for how she will do better in the future (see IU1, 3, and 5). This self judgment is most evident in IU3 in which she explains, "I find myself going to the same kids" (lines 63-64) and then declares, "I need to be more purposeful in my note taking" (lines 74-75). The phrase I find myself, which she uses three times, gives the interaction a confessional tone and signals that she knows she has done wrong and needs to change. This confessional tone continues into IU4 when she admits, in lines 83-84, that she does not always document conferences. Grace is then in the position of accepting the confession. She says, "It's okay. That's being honest" (lines 85-86) in a comforting tone 
in order to protect Katie from the shame and guilt of not living up to the expectations of best practice (Kletchermens, 2005; Zembylas, 2003).

This confessional tenor further highlights the asymmetrical nature of the interaction. Grace and Katie are wrapped up in what Foucault (1983) referred to as pastoral power. Within such a system of power, experts (often teachers, religious leaders, managers, etc.) seek to understand others' thoughts, emotions, and needs in order to look after them in ways which helps lead the individual into the fold (Bell \& Taylor, 2003; Boler; 1999; Fenwick, 2003). As such, Grace is the one who has the authority to evaluate and comfort, while Katie is in the subordinate position of seeking absolution. Katie acquiesces to this pastoral power by revealing her flaws through public self evaluation. At the same time, these confessions allow Katie to present herself as a reflective professional and, thus, maintain her image as a "good" teacher even though she has deviated from best practices.

Although the interaction is largely asymmetrical and monological, there is an appearance of agreement in the end. Katie concedes, "I think that will help me with the whole share out time" (lines 154-156) and "I think it will raise the level of expectation for them, raise the level of what they're sharing" (lines 201-204). She agrees that "it totally makes sense" (line 176). Yet, Katie is vague about which courses of action she believes will be helpful. There is no clear referent for that in line 155 or it in lines 176 and 201. These pronouns could refer to Grace's system of intentional planning and documenting of conferences or it could refer to any of the solutions that Katie mentioned in interactional units 1,3, and 5. Katie's vague referential pronouns allow her to agree with Grace and 
acknowledge the efficacy of the coaching interaction without committing to Grace's suggested course of action.

In the segment of the discussion immediately following this transcription, Grace summed up what their next steps of action would be, but these steps were never taken. Grace did not observe and co-confer as they had planned, and Katie did not change how she planned and documented conferences. In a later interview (5/23/13), Katie explained that she tried to conference more and that it did improve share time. But, she did so on her own terms, continuing to rely on in-the-moment decision making rather than on the procedures for scheduling and documenting that Grace advised. Although Grace asserted power as an authoritative expert during the coaching interaction, her power had limited influence in the classroom. Katie ultimately applied what she considered relevant to her daily work and ignored the procedural aspects of reading workshop, which she did not find meaningful.

\section{Reflection Meeting with Sophie}

Sophie is a first-grade teacher in her mid twenties. As a first year teacher, she is expected to work with the coach as part of the new teacher induction program. Grace worked closely with Sophie during the first semester because she "wanted help with the first time with readers workshop... and then she started wanting some help with getting math workshop looking like reading workshop" (Grace, paired Interview, 4/25/13). Grace helped Sophie by modeling mini lessons, teaching small groups, providing resources, and explaining "the architecture of all that" (Grace, Interview, 4/25/13). Sophie was grateful for Grace's support both in and out of her classroom. When I asked her about her opinion about the mentoring program, she shared, 
I have really liked having a mentor. I think that, like I told Grace, 'I probably would've cried a lot this year if I didn't have you.' Because it's so easy to just like either text her or just stop in and be like okay, 'Okay. This is my problem, or I don't know what to do with this.' And she always has the resources and ideas or advice, so it's been really helpful, I think. (Interview, 4/25/13)

Grace rarely visited Sophie's classroom during the second semester. She explained that she felt that she had laid sufficient ground work for Sophie to develop an initial understanding and implementation of the workshop model. She shared that in the first semester "we had full-on workshop going in math and reading in her room" (Interview, 4/25/13), so she felt confident that Sophie could sustain workshop with less support and guidance. In retrospect, Grace decided that she "did not appropriately gradually release" Sophie from support and did not focus "enough on the why" (Interview, 4/25/13). With frustration, she explained, "It was just like all of the sudden that connection that we had and was working was kind of falling apart" (Interview, 4/25/13). She was further concerned that Sophie may have made too many changes to the workshop model and, thus, abandoned best practices in favor of less desirable strategies. She recounted,

The last couple of months, she's never been at the guided reading table whenever I look in there. She's doing stations, and the word work station is just a worksheet. The listening station is just like a smiley face thing rather than bringing the journal to the station to do a journal response. (Interview, 4/25/13)

Grace was highly discouraged by Sophie's decisions in the second semester. As she shared, "I feel like that's my failure story of the year" (Interview, 4/25/13). 
During the second semester, Sophie was required to reflect on a videotape of a lesson in her classroom to fulfill requirements for the new teacher induction program. For this requirement, she chose to have Grace video record a writing workshop lesson on developing characters for realistic fiction. She chose writing workshop for the observation because Grace had never attended her writing workshop before, and she wanted to be sure that she was "doing it right" (paired Interview, 4/25/13). They met before the lesson, and Sophie requested that Grace watch for time on task and engagement for the students who were working independently while Sophie conferred or worked with small groups. The following transcript comes from an approximately twenty-five minute post-lesson discussion that occurred in Grace's office in March of 2013. They were watching the video of the lesson and simultaneously sharing their thoughts about the video. The transcribed portion below was approximately five minutes long and began at minute sixteen of the discussion (See Table 6.2).

The interaction focuses on what Sophie should do to improve independent writing time during workshop. In IU1, Grace initiates the interaction by summarizing what they have decided so far based on the observation of the video and by asking what else Sophie might like to change. Sophie answers that she may want to implement strategy groups. After a long pause while they continue to watch the video, Sophie shares in IU2 that she has "cut down the amount of independent writing time" (line 32). Grace disapproves of this decision and argues that most of the students can "handle a thirty, forty minute structured independent time" (lines 88-89). Then, Grace presents strategies for extending independent writing time: teaching another mini lesson (IU3a, 3b, and 3c) and writing partnerships (IU3d). Sophie attempts to participate in the conversation by interjecting 
stories about what she has done in the classroom (IU4a, 4b, and 4c), but Grace mostly ignores her and continues on with her suggestions for extending independent writing time.

\begin{tabular}{|c|c|c|c|c|}
\hline \multicolumn{5}{|c|}{$\begin{array}{l}\text { Table } 6.2 \\
\text { Transcription of Reflection Meeting with Sophie }\end{array}$} \\
\hline Time & Line & Speaker & Transcript & Contextualization Cues \\
\hline \multicolumn{5}{|r|}{ 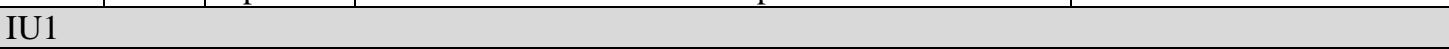 } \\
\hline \multirow[t]{9}{*}{ 16:09 } & $\begin{array}{l}1 \\
2 \\
3 \\
4 \\
5\end{array}$ & Grace & $\begin{array}{l}\text { besides possibly having multiple planners } \\
\text { or having the story paper ready for them } \\
\text { is there anything else } \\
\text { that you would want } \\
\text { to change for next time } \uparrow\end{array}$ & $\begin{array}{l}\text { Gaze directed mostly at } \\
\text { the video with a glance } \\
\text { back to her notes. }\end{array}$ \\
\hline & $\begin{array}{c}6 \\
7 \\
8 \\
9 \\
10 \\
11 \\
12 \\
13 \\
14 \\
15\end{array}$ & Sophie & $\begin{array}{l}\text { um | one thing I }|| \mid \\
\text { um } \mid \text { trying like the task groups } \\
\text { because there are } \\
\text { like if } \\
\text { Mark, Joshua, Nolan } \\
\text { that I know } \\
\text { have trouble putting their ideas on paper } \\
\text { where I could have just hit that } \\
\text { as a group } \\
\text { instead of going to individuals }\end{array}$ & $\begin{array}{l}\text { Her gaze is directed at the } \\
\text { video on the iPad. } \\
\text { Grace takes notes. } \\
\text { Directs gaze at Grace. } \\
\text { Directs gaze back at } \\
\text { video. }\end{array}$ \\
\hline & 16 & Grace & hm.mm & \\
\hline & $\begin{array}{l}17 \\
18 \\
19\end{array}$ & Sophie & $\begin{array}{l}\text { um }|| \mid \text { so I've been trying to } \\
\text { play around with that } \\
\text { but }\end{array}$ & \\
\hline & $\begin{array}{l}20 \\
21\end{array}$ & Grace & $\begin{array}{l}\text { so } \\
\text { *using strategy groups to help them* }\end{array}$ & $\begin{array}{l}\text { *said a little under her } \\
\text { breath as she writes it } \\
\text { down in her notes* }\end{array}$ \\
\hline & $\begin{array}{l}22 \\
23\end{array}$ & Sophie & $\begin{array}{l}\text { or yeah } \\
\text { what did I call them } \uparrow\end{array}$ & \\
\hline & $\begin{array}{l}24 \\
25\end{array}$ & Grace & $\begin{array}{l}\text { task groups } \downarrow \\
* \text { that's fine too* }\end{array}$ & $\begin{array}{l}\text { shaking her head slightly } \\
\text { *in a higher pitched, } \\
\text { comforting tone* }\end{array}$ \\
\hline & 26 & Sophie & oh & $\begin{array}{l}\text { laughs } \\
\text { looks at me/the camera }\end{array}$ \\
\hline & $\begin{array}{l}27 \\
28 \\
29 \\
30\end{array}$ & Grace & $\begin{array}{l}\text { *yeah } \\
\text { you know } \\
\text { that they need help } \\
\text { with those specific tasks* }\end{array}$ & $\begin{array}{l}\text { *said in a quiet voice* } \\
\text { Both of their gazes } \\
\text { directed at the video }\end{array}$ \\
\hline \multicolumn{5}{|c|}{ 17:03: A long pause while they continue to watch the video } \\
\hline \multicolumn{5}{|l|}{ IU2 } \\
\hline $17: 30$ & $\begin{array}{l}31 \\
32 \\
33 \\
34 \\
35 \\
\end{array}$ & Sophie & $\begin{array}{l}\text { one thing I've had to do } \\
\text { is cut down the amount of independent writing } \\
\text { time } \downarrow\|\| \\
\text { beca:use } \| \\
\text { once they hit that } \\
\text { like } 20 \text { minute mark }\end{array}$ & $\begin{array}{l}\text { Gazes directed at the } \\
\text { video. } \\
\text { shaking head } \\
\text { Grace takes notes, gaze } \\
\text { directed at paper. }\end{array}$ \\
\hline
\end{tabular}




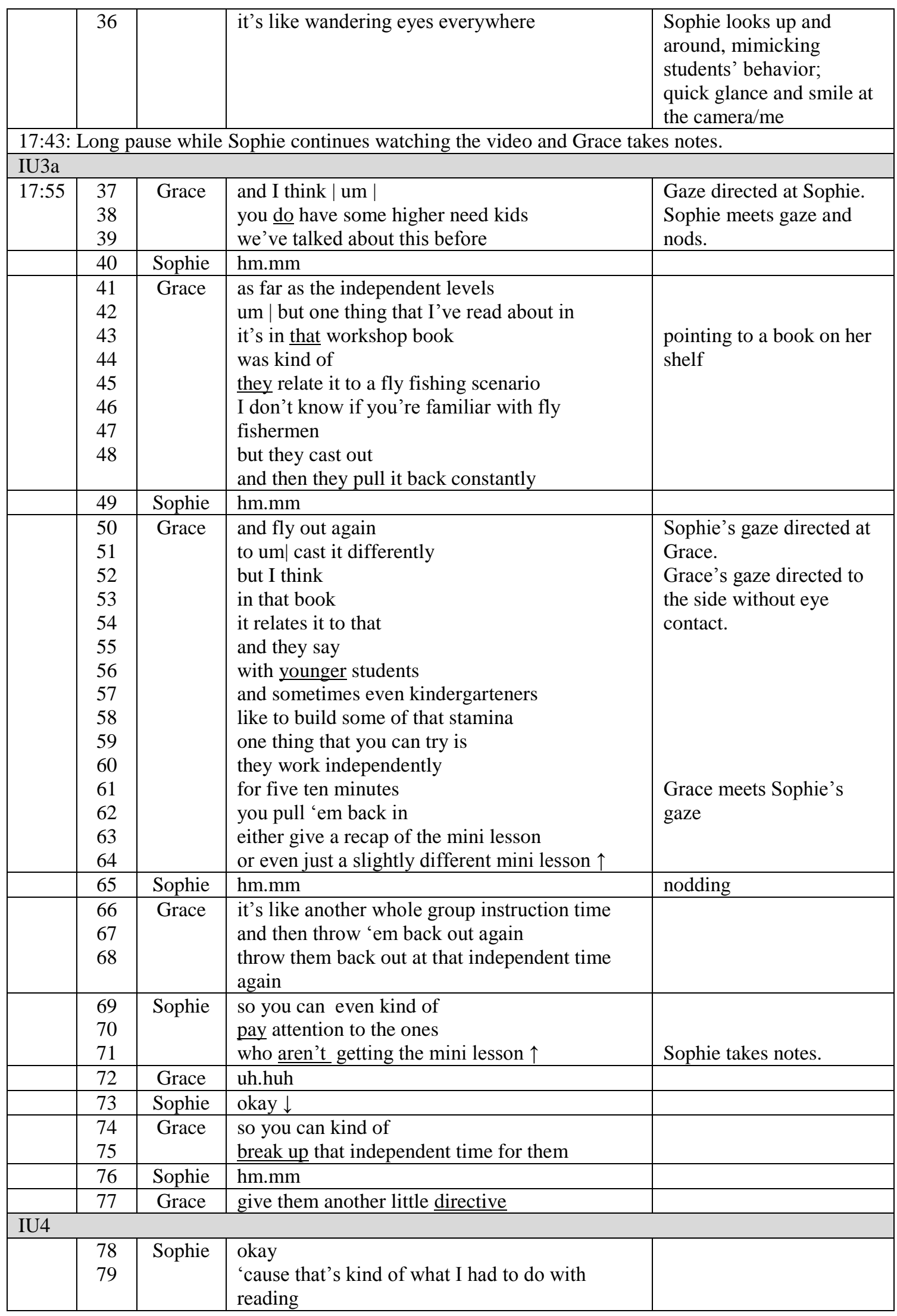




\begin{tabular}{|c|c|c|c|c|}
\hline & 80 & Grace & hm.mm & \\
\hline \multicolumn{5}{|l|}{ IU3b } \\
\hline & $\begin{array}{l}81 \\
82 \\
83 \\
84 \\
85 \\
86\end{array}$ & Grace & $\begin{array}{l}\text { directive instruction time } \\
\text { and um } \\
\text { at this time of the year } \\
\text { like you were saying } \\
\text { there's probably only a slight few } \\
\text { that might need to do that }\end{array}$ & \\
\hline & 87 & Sophie & hm.mm & \\
\hline & $\begin{array}{l}88 \\
89\end{array}$ & Grace & $\begin{array}{l}\text { there might be others in your room that can } \\
\text { handle } \\
\text { a } 3040 \text { minute [ structured independent time }\end{array}$ & \\
\hline \multicolumn{5}{|l|}{ IU5a } \\
\hline & $\begin{array}{l}90 \\
91 \\
92 \\
93 \\
94 \\
95 \\
96\end{array}$ & Sophie & $\begin{array}{l}\text { yeah } \\
\text { 'cause yesterday ] } \\
\text { we got done } \\
\text { and a majority of the class } \\
\text { was like } \\
\text { *we're done } \uparrow \text { we have to stop } \uparrow * \\
\text { and I was like }\end{array}$ & $\begin{array}{l}\text { *double voiced in } \\
\text { student's voice with a } \\
\text { higher pitched tone* } \\
\text { makes a surprised face }\end{array}$ \\
\hline & 97 & Grace & and that's a nice feeling & \\
\hline \multicolumn{5}{|l|}{ IU3c } \\
\hline & $\begin{array}{c}98 \\
99 \\
100 \\
101 \\
102\end{array}$ & & $\begin{array}{l}\text { so } \\
\text { if you know } \\
\text { that there are those kids out there } \\
\text { that are kind of starting to lose that stamina } \\
\text { that might be a time to pull }\end{array}$ & \\
\hline & 103 & Sophie & a group $\downarrow$ & \\
\hline & 104 & Grace & a strategy group & \\
\hline & 105 & Sophie & hm.mm & \\
\hline & $\begin{array}{l}106 \\
107 \\
108 \\
109 \\
110 \\
111 \\
112 \\
\end{array}$ & Grace & $\begin{array}{l}\text { give em a boost } \\
\text { give em an instructional focus } \\
\text { for a few minutes } \\
\text { send em back } \\
\text { or cast em back } \\
\text { throw em back out there } \\
\text { see if }\end{array}$ & $\begin{array}{l}\text { Grace gazes down at } \\
\text { video. Sophie gaze at } \\
\text { Grace. }\end{array}$ \\
\hline \multicolumn{5}{|l|}{ IU5b } \\
\hline & $\begin{array}{l}113 \\
114 \\
115 \\
116 \\
117 \\
118 \\
119 \\
120 \\
121 \\
122\end{array}$ & Sophie & $\begin{array}{l}\text { that's kind of } \\
\text { yesterday } \\
\text { I kind of let them go for awhile } \\
\text { and then I had the ones } \\
\text { that you could tell were struggling } \\
\text { like if they kept asking questions } \\
\text { come up with me } \\
\text { and then I was able to let them go } \\
\text { and yesterday } \\
\text { their writing was a lot better quality too }\end{array}$ & $\begin{array}{l}\text { Grace directs gaze toward } \\
\text { Sophie. Sophie's gaze } \\
\text { straight forward, not } \\
\text { making eye contact. }\end{array}$ \\
\hline & 123 & Grace & good & smiles and nods \\
\hline \multicolumn{5}{|l|}{ IU3d } \\
\hline & $\begin{array}{l}124 \\
125 \\
126 \\
\end{array}$ & Grace & $\begin{array}{l}\text { the other thing } \\
\text { um | that can help boost some of that } \\
\text { independent time } \\
\text { is some partnerships }\end{array}$ & gazes directed at video \\
\hline
\end{tabular}




\begin{tabular}{|c|c|c|c|}
\hline 127 & Sophie & hm.mm & \\
\hline $\begin{array}{l}128 \\
129 \\
130 \\
131 \\
\end{array}$ & Grace & $\begin{array}{l}\text { and / um } \\
\text { allowing them to get together } \\
\text { and ask some questions of a partner } \\
\text { or at least share their work with a partner }\end{array}$ & Sophie taking notes. \\
\hline 132 & Sophie & $\mathrm{hm} . \mathrm{mm}$ & \\
\hline $\begin{array}{l}133 \\
134 \\
135 \\
136 \\
137 \\
\end{array}$ & Grace & $\begin{array}{l}\text { can be some first steps for partnerships } \\
\text { and that can allow them to } \\
\text { even though they're working hard } \\
\text { and their brain is working during that time } \\
\text { it's a break from that same independent thinking }\end{array}$ & $\begin{array}{l}\text { gazes going back between } \\
\text { video and making eye } \\
\text { cocntact }\end{array}$ \\
\hline 138 & Sophie & hm.mm & \\
\hline 139 & Grace & s:o & \\
\hline $\begin{array}{l}140 \\
141 \\
142 \\
143 \\
\end{array}$ & Sophie & $\begin{array}{l}\text { and I think } \\
\text { that will help a lot of mine } \\
\text { because then they'll have that chance to talk } \\
\text { like a lot of em need that }\end{array}$ & \\
\hline $\begin{array}{l}144 \\
145 \\
146 \\
147 \\
148 \\
149 \\
150 \\
151 \\
152 \\
153\end{array}$ & Grace & $\begin{array}{l}\text { hm.mm }\|\| \| \\
\text { and just like what we worked on in reading } \\
\text { those have to be established } \\
\text { and correct ways to talk } \\
\text { and possibly some prompting cards } \\
\text { along with those } \\
\text { like we've done } \\
\text { in the math and reading workshop } \\
\text { so that they have a focus during that time } \\
\text { you want it to be productive for them }\end{array}$ & nodding \\
\hline 154 & Sophie & right $\downarrow$ & \\
\hline $\begin{array}{l}155 \\
156 \\
157 \\
\end{array}$ & Grace & $\begin{array}{l}\text { you just want them to be } \\
\text { thinking about their writing in a different way } \\
\text { it just stimulates their brain in a different way }\end{array}$ & \\
\hline
\end{tabular}

Sophie and Grace are in some degree of conflict concerning what counts as the relevant contexts and appropriate sources of knowledge for their discussion. This conflict is somewhat surprising given that the interaction is centered on a video of recent classroom instruction for the purpose of reflection on instructional practices. In such circumstances, it would be reasonable to expect that classroom experiences and teacher knowledge would be key focal points for the discussion. Indeed, Sophie attempts to focus the discussion on her practical classroom knowledge, but Grace focuses more on her own understandings of best practices for writers workshop, outside expertise, and procedural knowledge. For example, in IU5, Sophie attempts to refocus the discussion on successful 
events that occurred in the classroom "yesterday" (lines 91 and 114). In both cases, Grace briefly acknowledges Sophie's success, saying, "and that's a nice feeling" (line 97 and "good" (line 123). She transitions quickly, however, back to her suggestions for expanding independent writing time. Within this explanation, she draws on outside expertise when she attributes her suggestion to the authors of "that workshop book" (line 43). She also draws on local understandings of best practice when she refers to "that stamina" (line 101) and "that independent time" (line 125) and to other commonly discussed instructional strategies such as "partnerships" (line 126) and "prompting cards" (line 148).

In a similar vein, there is tension about who gets to be the expert. Sophie tries to assert an identity as a competent teacher and problem solver whose expertise lies in firsthand knowledge of her students. For instance, in IU1, she justifies her instructional decision making with an example about specific students, "Mark, Joshua, and Nolan" (line 10), and she emphasizes her practical knowledge with the phrases "because there are" (line 8) and "that I know" (line 11). Similarly, In IU2, she justifies her decision to "cut down the amount of independent writing time" (line 32) with a story about how there are "wandering eyes everywhere" (line 36) "once they hit that like 20 minute mark" (lines 34-35). In interactional units 5a and 5b, she interrupts Grace's suggestions for improving independent writing time to share success stories about how she has already been successful. She explains that "yesterday" (lines 91 and 114) the students didn't want to stop writing and that "their writing was a lot better quality too" (line 122) because she met with them in small groups. As such, Sophie resists a role as the passive recipient of Grace's instructions and attempts to reposition herself as someone who is actively 
making sense and problem solving based on deep personal knowledge of her classroom and her students.

Grace, however, does not recognize Sophie's identity as a competent teacher with expertise, and she consistently repositions her as a novice. For example, Grace corrects her in line 21, thereby asserting her expert knowledge of best practices and repositioning Sophie as a novice. Furthermore, she ignores Sophie's attempts to bring up the successful events from the previous day's instruction in IU4, 5a, and 5b. In IU3d, Sophie agrees with Grace's idea to use partnerships, stating, "and I think that will help a lot of mine because then they'll have that chance to talk, like a lot of them need that" (lines 140-143). Instead of acknowledging Sophie's agreement and expert knowledge of her students, Grace corrects her again. She assumes that Sophie will incorrectly implement the partnerships in an unstructured way, and so she insists, "you want it to be productive for them" (line 153). Grace is attempting to interact within an explanatory participant structure in which it would be more appropriate for Sophie to reply with a simple confirmation such as hm.mm or right. Thus, Grace treats Sophie's interjections as unwarranted interruptions.

Grace may be taking up this explanatory stance because she does not agree with the instructional decisions that Sophie has made and feels like she needs to help her reset her course. Her disagreement is clear within the twelve second pause between interactional units 2 and 3. During this time, Grace wrote notes on the Reflecting Conference Guide (See Figure 6.1), which is a required documentation for the new teacher induction program. Under the question What support do you need from me or others?, Grace wrote, "independent writing time: 20 minute stamina" and "partnerships" 
(See Figure 6.1). This is telling because Sophie was not, in fact, asking for support in these areas. Rather, she was sharing a story about an instructional decision that she made. She did so in a confident tone as indicated by her emphasis and strong downward intonation (lines 31-32). Sophie clearly was not asking for help with increasing stamina during independent writing time. Grace began to suggest instructional strategies to increase independent writing time because she disapproved of Sophie's decision to decrease it. She also argued that Sophie's interpretation was inaccurate and that many of her first graders could actually "handle" (line 88) a longer period of independent writing.

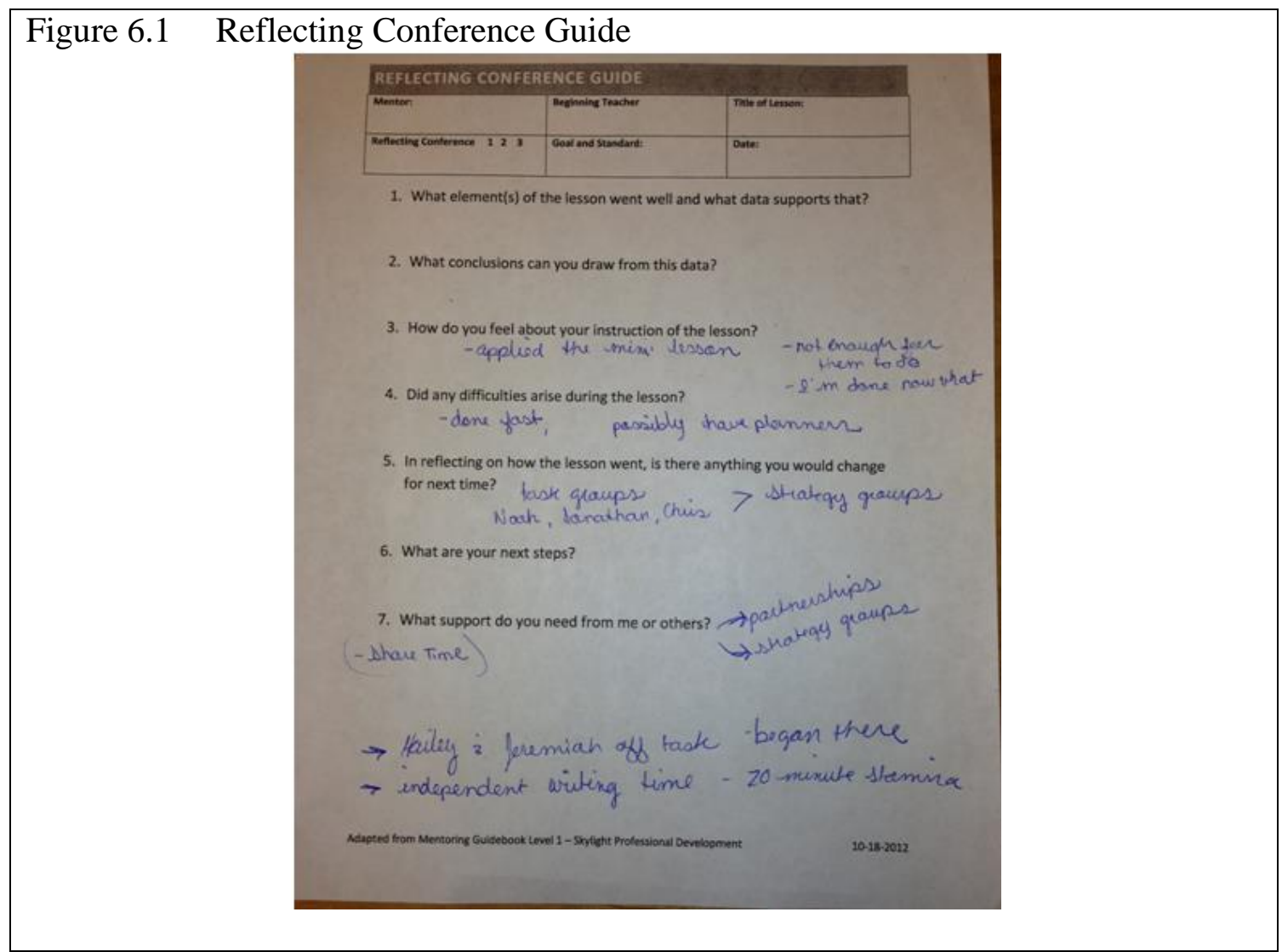

Grace explained her disagreement with Sophie's instructional decision making when I spoke with her later (Interview, 4/25/13). She said that Sophie is making hasty and unnecessary changes to her reading and writing curriculum based on an unusually 
difficult first grade class. She is afraid that Sophie will reject best practices and align herself with other $1^{\text {st }}$ grade teachers who do not implement workshop according to Grace's desired framework. She distrusts Sophie's classroom experience because she is too novice to have an adequate understanding of what is appropriate for first graders.

Since Sophie is, in fact, a first year teacher, it is seems reasonable for Grace to position her as a novice. However, novice status does not necessarily mean that she has nothing to offer, that she is incapable of making sense and problem solving, or that she has no valuable expertise (Dall'Alba, \& Sandberg, 2006; Grossman, 1992). Moreover, I argue that Grace does not position Sophie as a novice solely because she is a first year teacher, but also because Sophie's instructional decisions contradict Grace's understandings of best practice. She positions two of the other first grade teachers, who have many years of experience, as novices as well because they do not adhere to her definitions of best practice. These teachers are also seen as "new" to the workshop model and in need of support and guidance. Moreover, she believes that the veteran teachers' influence is "dangerous" (Interview, 4/25/13) because they encourage the use of stations and worksheets. Thus, even veteran teachers' practical knowledge and classroom experiences do not count as legitimate when they are not clearly aligned with best practice.

This interaction has an emotional tenor that resonates in relation to being positioned as a novice and to feelings of vulnerability. This tenor is most apparent in IU1d when Sophie uses the incorrect term, "task groups" (line 7) to identify a locally valued practice, “strategy groups" (line 21). When Grace corrects Sophie's terminology in line 21, she challenges Sophie's identity as a competent and knowledgeable teacher. 
Sophie immediately recognizes this challenge and sheepishly says, "Or yeah, what did I call them?" (lines 22-23). With this statement, she acknowledges that she has made a mistake. Grace then says, "That's fine, too" (lines 24-25) in a higher pitched, comforting tone and reassures her, "you know that they need help with those specific tasks" (lines 28-30). They both seem to understand that Sophie is in danger of losing face (Goffman, 1967). That face threat is intensified by my presence as the researcher, which is evidenced by Sophie's look at the camera in line 26 .

Furthermore, as I highlighted with Katie, pastoral power (Foucault, 1983) is at work because Grace has the authority to evaluate and comfort. Sophie, however, is less complicit than Katie was because she does not participate in self confession. Instead, she resists by asserting that she is already implementing best practices and achieving student success. She is less willing to admit weakness than Katie was in the previous transcript. Sophie's resistance may contribute to her inability to successfully position herself as a teacher with expertise and relevant knowledge. In order to align herself with the Discourse of reflective teacher, she would need to share her classroom experiences in a manner that focuses on what she has done wrong and on what she will do in the future to make amends. Her tactic, however, is to focus on the present and recent past to exhibit how she is already competent and compliant.

Even though Grace and Sophie are in conflict over what counts as relevant knowledge and who can claim expertise, the interaction does not seem contentious. Grace uses a variety of discursive tactics to maintain the appearance of collaboration, which obscures the ultimate lack of consensus. For instance, she attempts to establish that she is listening to Sophie when she says, "like you were saying" (line 84). She builds a sense of 
common ground by highlighting past conversations and co-teaching experiences. She says, "we've talked about this before" (line 39), "just like what we worked on in reading" (line 145). Sophie seems less concerned about "making nice" (Evans, 2001) since she resists the position of passive listener. Overall, the goal of the interaction does not seem to be to reach a consensus. Rather, Sophie's goal appears to be to establish a positive professional identity and to resist negative assessments of her teaching while Grace's goal is to help Sophie align her thinking and teaching with best practices.

\section{Summary}

Grace, Katie, and Sophie positioned themselves and one another within these interactions in relation to Discourses of best practices and teacher development. Their positionings were also influenced by their need to maintain credibility, decrease vulnerability and risk, and conform to local norms of collaboration and reflection. Although they were constrained by these Discourses, they simultaneously resisted them in unique ways as they negotiated what counts as relevant context and who has the right to speak about instructional practice.

They also positioned themselves and each other in relation to Discourses of development. Their interactions were limited in complicated ways by Discourses of development as a technical progression, as a stage model, and as vertical, monological, and individual. These Discourses, which are discussed in greater detail in the next chapter, played a significant role in how they negotiated what counts as relevant knowledge and experience, what constitutes expertise, and who has the power to evaluate instructional practices. 
Since teacher development and professional identity were closely associated with best practices, it was necessary for the teachers to align themselves with workshop methods in order to be viewed as "good" teachers. Sophie was less successful at aligning herself with best practices and asserting a positive teacher identity. Katie, on the other hand, was able to position herself positively by using tactics of reflection and confession. In both cases, a state of vulnerability was apparent in which the teachers felt the need to protect themselves from the shame and guilt often associated with deviating from best practices in education (Kelchtermans, 2005; Lasky, 2005; Schutz \& Zembylas, 2009; Zembylas, 2003).

Grace, Katie, and Sophie positioned themselves and one another in multiple and complex ways. The teachers, in particular, simultaneously resisted and accepted Discourses of best practice and development. This simultaneity allowed for alternative ways of knowing, understanding, and being to overflow into the dominant Discourses of the institution "by introducing into them the plural mobility of goals and desires" (de Certeau, 1984, p, xxii). In the next chapter, I will explore in more detail the coaches' and teachers' tactical "ways of making do" (p. 18) as they moved within "the established scientific fields" (p. 5) of best practices and development. 


\section{CHAPTER VII}

\section{COACHES AND TEACHERS AS FRAGMENTED SELVES}

As I have shown in chapters five and six, the coaches and teachers who participated in this study positioned each other in multiple and complex ways within coaching interactions. They simultaneously accepted and resisted powerful Discourses of best practices and teacher development. This sort of multiple, and sometimes conflicting, social positioning is a common experience in today's post modern world in which people co-construct “fragmented selves” (Day, Kington, Stobbart, \& Sammons, 2006; Deleuze \& Guattari, 1987; Pachler, Makoe, Burns, \& Blommaert, 2008) that are "produced, negotiated, and reshaped through discursive practices (Zembylas, 2003, p. 13). These "identities can be multiplex, strategic, logically inconsistent or incommensurable" (Lemke, 2012, p. 64) and, as Britzman (1992) argued, "because identity is negotiated with others within situational and historical constraints, its invention is dependent upon contradictions that cannot be reconciled" (p. 42).

The coaches and teachers in this study did not present stable, convergent, coherent selves within each interaction (Day et al., 2006), but instead positioned themselves and each other in seemingly contradictory ways in relation to the constraining Discourses and structures of their professional learning community. It was this contradictory positioning, this "interdiscoursivity" (Bloome et al., 2005, p.145) or "heterodiscoursia" (Matusov, 
2011, after Bahktin), that allowed them to tactically appropriate the Discourses for their own purposes and to insert other ways of knowing into the interactions. As de Certeau (1984) theorized, it is with "a degree of plurality and creativity" (p. 30) that "a tactic boldly juxtaposes diverse elements in order, suddenly, to produce a flash shedding a different light on the language of a place and to strike the hearer" (p. 38). Within this framework, the teachers' and coaches' multiple positionings can be viewed as "crosscuts, fragments, cracks and lucky hits in the framework of a system...the practical equivalents of wit” (p. 38).

\section{The Commodification of Best Practices}

Coaches and teachers used best practices as a commodity to support identities as "good" teachers and "good" coaches. Sarah and Grace aligned themselves with the local best practices that are associated with the workshop model, worked to transfer knowledge of instructional techniques to teachers, and encouraged the implementation of those techniques in the classroom. They frequently took an explanatory stance and gave directives about how to correctly implement aspects of workshop. The teachers aligned themselves with the Discourse of best practices by using the locally approved vocabulary of workshop methods and procedures (e.g. conferring, modeling, journaling, independent writing, frameworks, etc.). This alignment, achieved through discursive positioning, while tactical, was not necessarily intentional (de Certeau, 1984). Rather, it occurred in relation to the ebb and flow of the in-the-moment interactions between coaches and teachers (Davies \& Harré, 1990; Erickson, 2004) within a Discourse of best practices that has become a normalized, taken-for-granted part of being a teacher. Participation in this Discourse enhanced their professional image because it aligned with dominant 
perceptions regarding what "good" teachers do in today's educational climate (Davies, 2003; Day \& Gu, 2010; Day \& Sachs, 2004; Edwards \& Nicoll, 2006: Fenwick, 2003; Pachler et al., 2008).

This climate is increasingly influenced by what researchers have called new managerialism (Davies, 2003), fast capitalism (New London Group, 2000), neoliberalism (Fenwick, 2003), and post professionalism (Day \& Gu, 2010). These powerful ideologies "embed values of individualism, technicism, self-regulation and enterprise" (Fenwick, 2003, p. 336), emphasize standardization and uniformity of instructional practices (Pachler et al., 2008), and operate within systems of "management, surveillance and control” (Davies, 2003, p. 91). Teachers are constructed as consumers of knowledge produced by experts outside of the classroom (Cochran-Smtih \& Lytle, 2006; Shannon, 2001) and as technicians whose success is defined by others such as policy makers and administrators (Day \& Gu, 2010).

It is a "culture of compliance" (Eaude, 2011, p. 37) in which outside experts prescribe and mandate "evidence-based" or "scientifically-based" practices that teachers must effectively choose between in order to prove professional competency (Britzman, 2003; Cochran-Smith \& Lytle, 2006; Davies, 2003; Fenwick, 2003; Shannon, 2004; Webster, 2009). As Shannon (2004) argued, teachers are given the false illusion of choice when, "We [as educators] are free to choose, but not free to develop our choices" (p. 21). This element of a best practices Discourse was apparent in chapter six when Grace obscured her directives within a list of things that a teacher might do. Although she appeared to merely offer suggestions, the teachers' choices were limited to practices that aligned with the districts' conceptions of best practice. Within such limited 
understandings of what counts as best practice, "the notion of teachers' knowledge is at risk of becoming reduced to performative, pre-determinable items" (Fenwick, 2003. p. 349). In other words, educators are increasingly expected to set aside their professional and practical knowledge in order to perform according to high-stakes standards and assessments and to earn their status as highly qualified teachers.

There is nothing inherently wrong with aligning oneself with particular methods, but it is problematic when teachers are expected to suspend their professional judgment (Davies, 2003; Shannon, 2001; Webster, 2009). Such deprofessionalization promotes uncritical consumption of commodified best practices produced by textbook companies and educational consultants (Hargreaves, 2003; Shannon, 2001), erodes teachers' professional autonomy, and decreases ownership in instructional decision making (Hyslop-Margison \& Sears, 2010). In their interactions with teachers, Sarah and Grace often drew upon this depersonalized Discourse of best practices even though it sometimes conflicted with their desire to encourage teachers to think deeply about their practice.

Although Sarah often claimed to support critical thinking and reflection, she frequently positioned herself within the preceding interactions in ways that fostered compliance with best practices over critical professional judgment. For example, when Luke wondered if modeling was always an appropriate instructional strategy, she could have engaged in a dialogical conversation about its strengths and weaknesses. Such a conversation could have acknowledged Luke's practical experience and content-area expertise, promoted an inquiry stance, and supported a shared mission. Instead, she launched an explanation about how to implement modeling in his social studies classroom. Although it was not her conscience intention, she positioned Luke's ways of 
knowing as less valuable than the research-based practice of modeling. In other words, she drew upon a technical model of coaching that "reduced questions about ends, goals, and values in teaching to questions of means, techniques, and procedures" (Hargreaves \& Dawe, 1990, p. 234).

\section{The Productive Consumption of Best Practices}

Despite the dominance of this Discourse, the teachers did not simply consume the best practices pushed by Grace and Sarah as representatives of the district's initiatives. Rather, they inserted other ways of knowing into the dominant Discourse by telling stories of their own professional judgment within their classrooms. Even when they appeared to comply with prescribed procedures for implementing workshop methods, they often reworked them in terms of their understandings and goals. Through creative consumption, they appropriated best practices for their own purposes and transformed them into tools for building images as "good" teachers. As de Certeau (1984) theorized, this sort of consumption "is devious, it is dispersed, but it insinuates itself everywhere, silently and almost invisibly, because it does not manifest itself through its own products, but rather through its ways of using the products imposed by a dominant economic order" (p. xii-xiii).

Their subtle tactics and resistances illustrate how the Discourse of best practices "can only exist as one of the heterogeneous forces acting on teachers. Their philosophies of teaching, even if apparently erased, will nonetheless be visible in the palimpsest of meaning making and practices that make up classroom practice" (Davies, 2003, p. 101). In other words, even though the coaches and teachers were limited by and often reproduced dominant Discourses, they simultaneously resisted and appropriate them in 
ways that reflected their beliefs and identities. As de Certeau (1984) argued, there is a "multitude of 'tactics' articulated in the details of everyday life" (p. xiv) that teachers can use to construct an "antidiscipline" (p. xv) within the cracks of the powerful disciplines of surveillance and control (Foucault, 1977). Even though the teachers' choices were limited, they found "poetic ways of 'making do' (bricolage)" and were able to construct a "re-use of marketing structures" (de Certeau, 1984, p. xv).

\section{Selling Best Practices}

From their positions outside of the classroom, it was more difficult for the coaches to resist the dominant Discourse of best practices. Teachers had the power to "make do" in the classroom, creatively "poaching" in the Discourse of best practices to suit their own goals (de Certeau, 1984). Grace and Sarah, on the other hand, were separated from the classroom and struggled to maintain their identities as teachers. For instance, Sarah was frustrated that students, and sometimes other teachers, asked her if she was "really a teacher" (Interview, 4/9/13). Since the coaches had little day-to-day classroom experience to call their own, they drew on what de Certeau (1984) referred to as the "expert's discourse" in which the specialist is cut away from common, everyday life and can only "profit from knowledge by exchanging it against the right to speak in its name" (de Certeau, 1984, p. 13). From this position, they had little choice but to act as representatives, or sales people, of workshop methods. In a sense, they became evangelists within what Hargreaves and Skelton (2012) have referred to as a "performance training sect" (p. 132). They explained,

Performance training sects are like evangelical religious sects in which there is certainty about the knowledge of effective practice, an unchallengeable monopoly 
over the truths of effective instruction among the sect's leaders, an insistence on faithfulness or fidelity to the sect's instructional or professional beliefs, demanding standards and training rituals of obeisance and acceptance, and excommunication or banishment of non-believers. (p. 132)

Within this view, ideals of collaborative inquiry and self-driven learning are set aside in favor of promoting particular ways of understanding and practicing that are defined from afar according to dominant notions about what constitutes best practices. Within such a "normative cloak of professionalism" (Britzman, 2000, p. 202), complex questions concerning the consumption and production of knowledge are pushed aside. Questions such as what and whose knowledge is most valuable; which research base to use; and who gets to select best practices are ignored (Cochran-Smith \& Lytle, 2006; Davies, 2003; Fenwick, 2003; McWilliam, 2002; Shannon, 2001). Obscuring these essential questions leaves out the moral and political aspects of coaching and teaching (Hargreaves, 2001) and "asserts the unitary meanings we desire at the expense of recognizing the complicated constructs we live" (Britzman, 1992, p. 152).

\section{Tactical Positionings within Discourses of Development}

In addition to the Discourse of best practices, the coaches and teachers further positioned themselves and each other in relation to Discourses of teacher development. First, the influence of a best practices Discourse encouraged a technical conception of professional development in which the implementation of reading and writing workshop methods is considered to be the ultimate goal. They also drew on a Discourse of teacher development as a series of predetermined and universal stages between novice and veteran. Furthermore, the coaches and the teachers extended understandings of child 
development, such as the zone of proximal development (ZPD) (Vygotsky, 1982) and scaffolding (Wood et al., 1976) to teacher learning.

As Matusov (1998) argued, development is not an objective process; rather it is socially constructed and rooted in complex negotiations of values. Discourses of development are not neutral but "can be read as both a site of knowledge production and a system of power relations" (McWilliam, 2002, p. 290). Therefore, it is important to consider development in terms of power, positioning, and identity and in relation to broader social, historical, and political contexts (Lewis et al., 2007). Within the coaching interactions in this study, understandings of what learning and development mean influenced the participants' negotiations concerning what counts as relevant knowledge and who has the authority to make instructional decisions.

\section{Development and Best Practices}

Within a technical view of coaching, in which the coaches' role is to support the implementation of best practices, the possibilities of professional development are limited. Development is seen as a continuum from deficiency to mastery of skills (Cochran-Smith \& Lytle, 2006; Fenwick, 2003), and teachers' learning is conceptualized as linear and hierarchical with predetermined endpoints and a predictable trajectory (Day $\& \mathrm{Gu}, 2010)$. Development was often constructed in these terms in the coaching interactions. For instance, as noted in chapter six, Grace attempted to redirect Katie and Sophie along the path of correctly implementing workshop methods and procedures. The teachers' experience, learning, and professional sense making only counted as progress when it aligned with the Discourse of best practices. Similarly, Sarah often focused on 
teachers' compliance and ability to apply specific, learned skills as an evidence of their progress rather than on other possible evidences of professional growth.

This techno-rational model of professional development nudges out other possibilities for professional learning such as action research and teacher inquiry (Cochran-Smith \& Lytle, 2006) and attempts to erase the ambiguities and uncertainties that are an inherent part of learning and collaborating. It excludes the "difficult knowledge... where teacher learning and practice are bound up in working through one's deepest desires and resistances" (Fenwick, 2003, p. 351). de Certeau (1984) described this view of development as a "flattening out" of everyday people's unpredictable movements and tactics. It turns what are opportunistic and artistic processes into a "relic in place of performances...the sign of their erasure" (p. 35). The techno-rational viewpoint reduces complex developmental trajectories into "a line that can be seized as a whole by the eye and read in a single moment, as one projects onto a map the path taken by someone walking through a city" (p. 35). It ignores the process of becoming, or how people move through the institutional spaces of schools, and focuses instead on mapping out a rule-governed, "proper place" (p. xix).

\section{A Stage Model of Development}

Another prominent Discourse in this study constructed development as stages of expertise along a continuum from novice to expert. Such stage-model conceptions of development "paint a too conceptually simple and decontextualised picture of the relationship between, for example, context and experience" (Day \& Gu, 2010, p. 27; Edwards \& Nicoll, 2006), and they discount the complex ways that teachers construct their experiences within shifting cultural contexts (Britzman, 2003; Day \& Gu, 2010). 
This Discourse of development played out in complicated ways in the coaching interactions. For example, Sarah described novice teachers as more susceptible to feelings of discouragement and vulnerability and, thus, more willing to accept her support than veteran teachers. This view implies that veteran teachers are more resistant to coaching and to implementing best practices despite the fact that the veteran teachers in this study willingly collaborated and actively worked to implement workshop methods. Both coaches described veterans' experience as a liability that could interfere with the successful implementation of new best practices. As Sarah argued, "With a veteran teacher, it's easy to go back to things that you've always done if something new doesn't work...I think when you're a newer teacher you don't have something that set in place that you've done forever" (Interview, 4/9/13).

At times, the teachers in this study resisted their positions within this view of development. Novice teachers found opportunities to assert identities as competent professionals. For example, Luke denied feelings of discouragement and demonstrated expertise in workshop vocabulary in an attempt to redefine his novice status. Similarly, Sophie spoke with confidence about her past instructional decision making and her recent successes in the classroom.

\section{The ZPD and Deficit Positionings}

Within a Vygotskian Discourse of development, Sarah was the expert, who must provide scaffolding in the zone of proximal development to the less-competent teachers. Sarah identified strongly with this Discourse and frequently referred to Vygotsky during a book study that occurred before school for several weeks. She admired his emphasis on the social co-construction of knowledge and believed that her coaching practice was 
guided by his philosophies. Based on her understandings of Vygotsky's theories, she argued that "sometimes you are that expert other" within coaching interactions and it is “just a natural part of having experience" (Interview, 5/21/13). This philosophy, which deemphasized power relations to focus on benevolent support, was an important part of her coaching identity. I did not ask her about being a more expert other, but she knew from previous conversations with me and others whom I had interviewed that I was critical of the construct. Thus, she brought up the topic in order to assert her perspective on expertise and power within coaching interactions, which further indicated that she felt strongly about Vygotskyian constructs such as the ZPD.

Vygotsky's theories have provided invaluable contributions to the field of education and, in many ways, are highly applicable to coaching due to his revolutionary conceptions of learning as a socially-mediated process. However, as I argued in chapter two, there are significant limitations within his developmental theories that are important to consider, especially when applying them to adult professional learning. For instance, the ZPD assumes a deficit gap between the child and adult, or when applied to coaching, the teacher and the coach (Matusov, 2011) and emphasizes "vertical improvement" from a state of deficiency to a state of enlightenment (Engetsröm, 2005, p 45). As such, teachers are positioned as in need of help and support (Edwards \& Nicoll, 2006; McWilliam, 2002). As McWilliam (2002) argued, "because development is always predicated on the idea that someone is knowledge-able while someone else is knowledge deficient, such communication cannot be a conversation among equals" (p.290).

This deficit positioning was seen throughout the coaching interactions, particularly in chapter five within Sarah's discussions with novice teachers and her offers 
of support. It seems to be common sense that new teachers need help, but as Engetsröm (2005) argued, learning is "not just the more competent pulling up the less competent. It is always also a question of entirely different worlds meeting" (p. 45). As such, understanding one another and negotiating what is learned and how are essential elements of development in which both the novice and the expert learn from one another through shared participation (Matusov, 1998, 2011). Furthermore, development "is always an ideology" (Matusov et al., 2007, p. 417), so it is important to attend to questions such as what counts as progress, knowledge, and expertise.

\section{Constructing Identities as "Good" Teachers and Coaches}

Within a deficiency Discourse of development, professional learning and growth are represented as individualistic and self-regulatory (Fenwick, 2003). The teacher, through a process of continual self-improvement, is responsible for closing the perceived deficiency gap and achieving predefined outcomes (Pachler et al., 2008; Fenwick, 2003). As Zembylas (2003) pointed out, "In the United States and England, school teachers teach in contexts that encourage individualism, isolation, a belief in one's own autonomy, and the investment of personal resources" (Zembylas, 2003, p. 119). A teacher may have the support of the coach to help them implement best practices (Hargreaves \& Skelton, 2012), but they maintain the burden of proving their professional credibility and worth within a culture of performance based on measurable outcomes such as student achievement data (Pachler et al., 2008) and fidelity of implementation (Fenwick, 2003; MacGillivray et al., 2004).

Within this view, teachers are developed towards being a particular kind of "good" teacher, one that will not upset the dominant Discourses at play in local, state, 
national, and global contexts (Devos, 2010; Fenwick, 2003; McWilliam, 2002). As Edwards and Nicoll (2006) argued, "Professional development becomes a form of identity work" (p. 124) in which "a particular pedagogic identity is positioned as the pedagogic identity, attempting to mobilize an audience to practice in particular ways" (Edwards \& Nicoll, 2006, p. 126). Coaches unwittingly become "part of the politics of delivery" (Hargreaves \& Skelton, 2012), and coaching becomes "a technology for the production of worker identities" (Devos, 2010, p. 1222). In order to be recognized as "good" coaches and maintain their authoritative positions within the "discourse of the expert" (de Certeau, 1984), they must work to construct "particular sorts of teachers" (Devos, 2010, p. 1222) through their coaching.

Take, for example, the model of the "good" teacher as reflective. Within this model, 'a certain sort of autonomous worker-learner, 'a reflective practitioner,' is valorized, drawing on understandings from humanist psychology about the nature of identity" (Nicoll \& Harrison, 2003, p. 27). Teachers are required to internalize "a normalizing gaze" (Foucault, 1977, p. 184) in which they shape their identities through technologies such as "examination, confession, guidance and correction" (Bell \& Taylor, 2003, p. 340). In chapter six, I highlighted how Katie enacted this model of the "good" teacher when she "reflected" about the mistakes she had made in the classroom and how she might change her instruction. Such self-reflection can be an asset for teachers as it can foster growth and agency; however, in Katie's situation, the only accepted path of self improvement was one that would align her most closely with workshop methods and procedures. Although she was able to tactically and effectively position herself as a "good" teacher, there were limited options. She could be the reflective teacher and/or the 
compliant teacher. As MacLure (1993) argued, "The holistic ideology of self-discovery or self-improvement may actually mask a narrowing down of the range of options as to what a person may be or become, into a small set of coercive identities" (p. 321).

\section{Conditions of Vulnerability}

The teachers and coaches struggled to live up to these ideals of the "good" educator within conditions of increasing vulnerability (Hargreaves, 1998; Kelchtermans, 2009). Kelchtermans (2005) defined vulnerability as a "structural condition" (p. 998) in which "one's professional identity and moral integrity, as part of being 'a proper teacher', are questioned" (p. 997). de Certeau (1997), although speaking about universities, accurately described the current condition of vulnerability among K-12 teachers as follows,

Among teachers, a feeling of insecurity has emerged. It coexists with the consciousness of their exteriority with respect to the place where culture develops-- factories, the mass media, technical centers, corporate enterprises...Teachers float on the surface of culture, defending themselves all the more in that they know they are becoming an endangered species. They stiffen, and they are inclined to enforce the law on the boundaries of an empire of which they remain unsure. (de Certeau, 1997, p. 59)

This vulnerability was evident within the coaching interactions as coaches and teachers positioned themselves in relation to best practices in ways that asserted their identities as competent professionals. In these in-the-moment interactions, it seems that the coaches and teachers were mostly unaware of how they reacted discursively to defend themselves against emotions such as shame, guilt, and fear. They did, however, show 
awareness of their professional vulnerability in other situations. For instance, the coaches often joked about the possibility that they would all be kindergarten teachers next year because their coaching positions might be cut. These jokes indicated insecurity in their positions as leaders and served as a way to safely express their emotions about the devaluing of their work. Teachers' vulnerability stemmed from the precarious nature of their professional credibility, and as such, they frequently expressed a fear of "looking stupid" in front of coaches, colleagues, administrators, and me as the researcher.

Teachers often experience emotions such as fear, guilt, and shame within such conditions of vulnerability (Boler, 1999; Fenwick, 2003; Kelchtermans, 2005; Zembylas, 2003). As Zembylas (2003) argued, teachers may feel a sense of "powerless and personal inadequacy" (Zembylas, 2003, p. 121) if they deviate from prescribed norms of teacher professionalism and district-sanctioned best practices. In the coaching interactions, teachers actively defended themselves against such feelings of vulnerability by asserting identities as "good" teachers and, in Katie's case, by preemptively confessing her deficiencies. It is important to note that these emotional positionings were not simply "natural" or involuntary reactions to the environment or to the coaching interactions. Rather, emotions were socially co-constructed through their in-the-moment, discursive negotiations and in relations to broader ideological Discourses concerning best practices and development. Teachers and coaches only needed to actively avoid shame, fear, and guilt because they were co-constructing their identities in relation to idealized, universalistic, and individualistic notions of the "good" teacher and "best" practices. Within other, less constraining Discourses, they may have been able to co-construct their identities and emotions differently. For instance, we might ask what identities and 
emotions would have been possible within critical, feminist, or poststructuralist developmental and pedagogical Discourses (Devos, 2010).

\section{Norms of Collaboration and "Making Nice"}

The coaches' and teachers' efforts to decrease their vulnerability negatively influenced their collaborative efforts. Collaboration requires a certain amount of risk taking and discomfort. When coaches and teachers are insecure in their positions and feel that they need to protect and defend their professional identities, it can be daunting to take such risks. As Hargreaves (1998) argued, "It is naïve to advise teachers to be stronger risk-takers, unless we also consider the context in which risks must be taken" (p. 327). For Sarah, Grace and the teachers, the context included constraining Discourses of best practices and development in which they felt the need to prove their effectiveness and compliance. Their vulnerability was experienced in relation to a culture of performance anxiety in which teachers are judged according to predetermined and fixed visions of effective teaching.

As such, the local norms of compliance hindered the productive sort of vulnerability that is possible within contexts of mutual respect in which teachers and coaches may interact as critical friends (Sachs, 1997). As Hargreaves (1998) argued, "Professional development, where colleagues learn from one another's differences...necessarily involves moments of discomfort and anxiety, of challenges to the self' (p. 324). Such challenges, however, are difficult to withstand when there are strict guidelines about what constitutes an appropriate and effective teaching self. When the characteristics and practices of a "good" teacher are predetermined and certain, there are limited options for constructing agentive identities. 
Since vulnerability was a negative condition within their learning communities, the coaches and teachers worked to avoid it in their interactions by supporting an image as compliant professionals. They utilized what Evans (2001) referred to as the Discourse of "making nice," which "emphasizes comfort and conflict avoidance" (p. 107) and is common among White, middle-class, female teachers. The coaches and teachers often held the appearances of agreement even though there were significant tensions concerning important issues such as what counts as relevant knowledge and what it means to be a "good" teacher. They consistently utilized discursive moves such as confirmations, positive evaluations, head nodding, and gesture mirroring in order to obscure conflicts and to further cement identities as "good" teachers who are compliant and get along well with others. These "making nice" moves are somewhat necessary for communication, but they can be problematic when they obscure the challenges, uncertainties, and ambiguities that are essential elements of meaningful professional development.

In addition, the coaching interactions were often monological (Bakhtin, 1981) in that the coaches and teachers maintained their own perspectives and did not openly acknowledge any gaps in their mutual understandings. As such, the coaches and teachers talked at each other instead of deeply engaging in conversations. Indeed, the interactions seemed to be predicated on monological notions of development and learning in which "someone who knows and posses the truth instructs someone who is ignorant of it and in error" (Bakhtin, 1984, p. 81). Such monological coaching interactions leave out opportunities for "mutual surprise...mutual wonder about each other... and mutual respect of one another's agency of decision-making" (Matusov, 2011, p. 103). 
Hargreaves and Dawe (1990) referred to such limited forms of collaboration as “contrived collegiality" (p. 238). Within systems of contrived collegiality, decision making and curriculum development are outside of the teachers' purview and are instead left to outside experts and policy makers. Theory is separated from teachers' practice and experience in a way that obscures any doubts they may have about instructional mandates or "research-based" practices. Therefore, "collaborative" conversations are reduced to explanations of technical details of implementation and leave out critiques or discussions of purposes. Within this limited framework of professional development, coaches "may be fostering training, not education, instructional closure rather than intellectual openness, dispositional adjustment rather than thoughtful critique" (p. 229).

\section{Summary}

In this chapter, I have presented an extended theorization of how the literacy coaches and teachers reproduced dominant Discourses of best practices, teacher development, collaboration, and credibility while simultaneously resisting and appropriating them. These simultaneous positionings are notable because they affect coaches' and teachers professional and personal identities. Furthermore, they allow for complex power negotiations in which both coaches and teachers can maintain agency despite powerfully dominant ideologies about effective teaching and learning. In the concluding chapter, I present such implications about literacy coaching and research in more detail. 


\section{CHAPTER VIII}

\section{CONCLUSION}

Throughout this study, I attempted to shed light on how literacy coaches and teachers discursively positioned themselves in relation to each other and to dominant Discourses. As I conducted this exploration, I encountered deep complexities as the coaches and teachers defied simple understandings or categorizations. Often, what I saw within the coaching interactions seemed to directly conflict with the stories told in research interviews or with my perceptions of the participants and their relationships. For instance, I wondered how the literacy coaches could dominate coaching conversations yet be highly respected as active listeners by the teachers. I came to understand that they could simultaneously enact conflicting positions and identities and simultaneously assert and resist power. This understanding was important because it helped me to move beyond simple conceptions about effective literacy coaching to explore the complex ways that coaches and teachers negotiate what professional learning means.

Therefore, it is not my intention to develop a model of literacy coaching or to suggest how literacy coaches and teachers should interact with each other or structure their professional learning. Moreover, I do not wish to evaluate how the coaches and teachers positioned one another or suggest that they were doing a "bad" job. Instead, my aim is to highlight how educators and policy makers might deepen their understandings of powerful ideologies such as best practices and development, acknowledge complicity 
in reproducing those Discourses, and work to limit their constraining power.

Furthermore, I wish to point out the potential of valuing educators' practical and emotional ways of knowing.

To this end, I first return to my research questions and give a brief overview of my findings for each one, situating them within the larger body of literacy coaching research. Then, I share implications for coaching practice, for research on literacy coaching, and for microethnographic research. Finally, I discuss the limitations of the study and share some final thoughts about what I have learned about literacy coaching, professional learning, and research processes through this endeavor.

\section{Summary of Findings}

\section{Research Question 1}

My primary research question was: How do literacy coaches and teachers discursively negotiate issues of identity, power, and positioning during coaching interactions? This is a very complex question, and therefore, there is no simple answer. As I illustrated within my analyses of the coaching interactions, the literacy coaches and teachers multiply positioned themselves and each other in relation to dominant Discourses. Moreover, they simultaneously resisted these dominant Discourses by calling forth other ways of knowing and understanding into their interactions.

Several prominent Discourses circulated within the coaches' daily work and within the specific coaching interactions that I documented in this study. These Discourses constrained the teachers and coaches, yet they often resisted them in surprising ways. The Discourse of best practices limited what counted as relevant knowledge and context for making instructional decisions, and there was a heavy 
emphasis on the "correct" way to implement workshop methods. Yet, the teachers also inserted other ways of knowing rooted in their classroom practice. A Discourse of development as a linear, hierarchical, individual progression towards the implementation of best practices limited the possibilities for change and innovation. Yet at times, the coaches and teachers recognized that such simplified understandings of development were inadequate for promoting deep learning and meaningful collaboration. Furthermore, the coaches' efforts to establish credibility, along with local norms of collaboration such as "making nice," kept the interactions at a surface level and promoted what Hargreaves \& Dawe (1990) called “contrived collegiality” (p. 227).

The literacy coaches' and teachers' identities were constrained by these dominant Discourses in a variety of ways. Most prominently, the Discourse of best practices influenced their enactment of identities as "good" coaches and teachers. Throughout the interactions, tensions arose related to what it means to be a "good" teacher and who gets to define it. Ultimately, teachers and coaches were more likely to be deemed "good" if they conformed to workshop methods. However, coaches and teachers simultaneously enacted other identities as they positioned and repositioned themselves and each other in relation to conflicting Discourses. For instance, the coaches worked to construct identities as non-evaluative, collaborative partners, and the teachers worked to assert identities as competent professionals who could make decisions based on their practical knowledge and professional judgment. Although the coaches' institutional identities as experts and promoters of best practice were the most visible across the coaching interactions shared in this study, it is uncertain which identities were emphasized in other environments. In fact, given the teachers' overwhelmingly positive reviews of the literacy coaches' work, 
it is likely that the coaches were more successful at enacting their collaborative identities in other settings that were less formal and outside of my research gaze.

Because the literacy coaches directed much of the flow and content of the interactions, it would be easy to assume that the literacy coaches were more powerful than the teachers. However, as my analysis has shown, power circulated between the coaches and teachers in interesting ways, and neither coaches nor teachers can be easily understood as asserting power or as lacking agency. In de Certeauian terms, coaches and teachers each simultaneously used strategies, associated with powerful dominant Discourses, and tactics, associated with contextualized ways of knowing. For instance, the coaches were strategic when they used the best practices Discourse to support their expert status and maintain credibility. They aligned themselves with workshop methods, assuming "a proper place" (de Certeau, 1984, p. 55) within the district's initiatives for school reform. Unlike the teachers, however, they lacked the "proper place" of having their own classroom. As such, they used tactics to gain access to instructional spaces and the teachers' trust. Teachers, on the other hand, strategically maneuvered within the classroom, making the ultimate decisions about what occurred in their classrooms on a daily basis. They were tactical in their interpretations of workshop methods and in their efforts within the coaching interactions to position themselves as "good" teachers. Power relations consisted of a constant push and pull between conflicting Discourses and multiple identities as coaches and teachers navigated through shifting social positions.

These findings support and extend other research on literacy coaching that has acknowledged issues of identity, power, and positioning (Coburn \& Woulfin, 2012; Hargreaves \& Skelton, 2012; MacGillivray et al., 2004; MacPhee, 2013; Mangin \& 
Dunsmore, 2013; Rainville \& Jones, 2008). For instance, several researchers have acknowledged the political nature of literacy coaching and argued for the importance of attending to the ways that power circulates within coaching relationships (Coburn \& Woulfin, 2012; Hargreaves \& Skelton, 2012; MacGillivray et al., 2004; Mangin \& Dunsmore, 2013). These researchers have also highlighted how the powerfully dominant Discourse of best practices can limit coaches' and teachers' collaborative work. I extended this line of research by applying a microethnographic lens to such issues, which sheds light on specific ways that dominant Discourses are discursively produced and resisted within real-time coaching interactions.

My findings further support and extend literacy coaching research that has focused on the shifting and multiple nature of coaches' identities as they move across contexts and between relationships with teachers (MacPhee, 2013; Rainville \& Jones, 2008; Stevens \& Hinchman, 2011). Such an emphasis highlights the complex interpersonal work that coaches and teachers do as they position themselves and each other in multiple ways, and it illustrates that coaching is more complicated than enacting a particular role or taking up a certain stance. This study extends this line of research by highlighting the simultaneity of coaches' and teachers' identities as they maneuver within competing Discourses to be viewed as "good" teachers and coaches.

\section{Research Question 2}

A secondary research questions was: How do literacy coaches and teachers enact emotions within their discursive negotiations of identity, power, and positioning? Emotions related to vulnerability were the most evident within the coaching interactions. The participants discursively and tactically positioned themselves to reduce feelings of 
shame, guilt, and fear associated with their attempts to maintain identities as "good" teachers and coaches. They rarely explicitly stated these emotions, however, as the "emotional rules" (Zembylas, 2005) of the learning community diminished the value of emotional ways of knowing in favor of a rational, "research-based" Discourse of best practices. Moreover, positive emotions, such as hope and care, were more readily accepted than negative emotions. To claim negative feelings, such as discouragement, was to admit professional weakness and to accept a position as deficient and in need of help.

While many researchers have acknowledged that emotions play an important role in literacy coaches' daily work and their interactions with teachers (Gibson, 2005; Gibson, 2006; Hays \& Harris, 2003; Kissel et al., 2011; Mangin \& Dunsmore, 2013; Mangin \& Stoelinga, 2011; McKinney \& Girogis, 2009; Smith, 2007), few have specifically explored emotions in literacy coaching (Hunt \& Handsfield, 2013). This study deepens the understanding of how coaches and teachers "do emotions" (Zembylas, 2005, p. 211) to discursively position themselves and each other in relation to dominant Discourses.

\section{Research Question 3}

Finally, I asked: How are physical, social, and ideological spaces shaped by and reflected in interactions between literacy coaches and teachers? Within the coaching interactions, the coaches and teachers constantly negotiated what counts as relevant knowledge and where knowledge should be produced. The dominant Discourses favored "best practice" knowledge that was produced by experts outside of the school. Although the teachers often aligned themselves with the Discourse of best practice, they also 
asserted the value of their own knowledge, which they produced through their daily work with students in the classroom. Control over what occurs in the classroom was contested as well. The coaches attempted to promote the implementation of best practices, but the teachers made the ultimate decisions about instructional practice, sometimes creatively appropriating workshop methods for their own purposes. Furthermore, coaches and teachers negotiated which spaces in time were most relevant. The teachers often focused on past and present classroom experience while the coaches frequently oriented their conversations to the future. This difference in orientation often led to a disjuncture in their interactions, and coaches and teachers talked at instead of to each other because they did not have a shared understanding of relevant context.

Much of the research on literacy coaching considers space as a backdrop for professional learning (Asaf, 2005; McKinney \& Giorgis, 2009; Scott et al., 2012; Smith, 2007) without acknowledging how space operates in the production of and resistance to dominant Discourses within literacy coaching interactions. My findings support the few studies that have treated space more robustly within literacy coaching research (Crafton \& Kaiser, 2011; Hunt \& Handsfield, 2013; McLean et al., 2010; Stevens \& Hinchman, 2011) by similarly illustrating how literacy coaches and teachers discursively negotiate spaces to co-construct new understandings and diverse social positionings.

The microanalytical lens that I employed in this study allowed me to give a more detailed account of how coaches and teachers produce and are influenced by space within schools. Few researchers have considered the political dimensions of literacy coaching (Coburn \& Woulfin, 2012; Hargreaves \& Skelton, 2012; Hibbert et al., 2008; Hunt \& Handsfield, 2013; Ferguson, 2011; MacGillivray et al., 2004; Mangin \& Dunsmore, 
2013), and even fewer have included video data of coaches' work with teachers (Rainville \& Jones, 2008) or employed discourse analysis (Crafton \& Kaiser, 2011; Hargreaves \& Skelton, 2012; Hinchman \& Stevens, 2011; McLean et al., 2010). This study is among the first to combine these approaches to closely analyze how dominant Discourses circulate within and across in-the-moment coaching interactions and how coaches and teachers reproduce, resist, and appropriate them. As such, it provides valuable insights into how professional development through literacy coaching is enacted and experienced at a micro-level in relation to broader ideological structures.

\section{Limitations}

While the findings discussed above are significant, there are several limitations to this research concerning the methods and scope of the project. First, throughout the study, I became aware of the complex ways in which my use of the video camera complicated social positionings (Erickson, 1982). As the researcher, I felt that the coaches and teachers were less comfortable when I was behind the video camera than when I was taking field notes by hand. At times, as I set up the camera, the participants commented about how it made them nervous. Other times, teachers glanced at the camera during recording. The video camera seemed to bring with it an air of extra authority, and I wonder if the coaches and teachers modified their interactions in reaction to its gaze, performing their best interpretations of "good" teacher or coach for me, the videographer. As Shrum, Duque, and Brown (2005) found in their digital video research on globalization and science, the camera became "an actor in the drama of the project" (para. 22). I also struggled with details of video recording such as camera placement, angle, and shot length (Roschelle, 2000; Shrum, Duque, \& Brown, 2005). I decided to set 
the camera up on a tripod to keep the frame frozen and focused on the coaches and teachers. How would my data have been co-constructed differently if I had held the camera in my hand, moving the frame or zooming in and out?

Furthermore, I acknowledge that the interactions that I have shared in this study only represent a small portion of the literacy coaches' and teachers' work together, and thus, I am only able to offer a partial story of how the literacy coaches and teachers positioned themselves and each other. As Britzman (1999) explained, "Every telling is constrained, partial, and determined by the discourses and histories they prefigure" (p. 32). It was clear as I analyzed the data that even though there were consistencies across the coaching interactions, they were necessarily only partially representative of how the coaches and teachers made sense of their collaborative professional learning. Although there were missed opportunities for inquiry and collaboration in the interactions that I have shared, the coaches, teacher, and administrators all spoke positively about what they accomplished and the close relationships between coaches and teachers. Thus, I am left asking myself what I did not see. What other ways of knowing, understanding, and interacting circulated among the coaches and teachers outside of my research gaze? It is possible, as de Certeau (1984) argued that other, less powerful and less visible Discourses were also in circulation alongside the dominant Discourses. As he argued, "It remains to be asked how we should consider other, equally infinitesimal, procedures, which have not been 'privileged' by history but are nevertheless active in innumerable ways in the openings of established technological networks" (p. 49).

These reflections about the limitations of my work acknowledge how my "own guilty readings of other people's dramas" (Britzman, 1999, p. 33) affected what I was 
able to see and how I interpreted the data. As such, my findings are not meant to be representational or generalizable to all literacy coaches or their interactions with teachers. Likewise, I do not intend to suggest a set of appropriate identities and tactics for literacy coaches and teachers to enact. Rather, these findings are meant to stress the political and emotional nature of literacy coaching interactions and to highlight the differences, conflicts, uncertainties, and ambiguities that are an inherent part of literacy coaches' work. Moreover, these findings encourage a move away from essentialist ideas about what it means to develop as an educational professional and what constitutes the "good" teacher or "good" coach.

\section{Implications for Practice}

Despite its limitations, this study has several important implications for literacy coaching, which are also relevant for other fields such as continuing professional development, instructional leadership, and professional learning in general.

\section{The Consumption and Production of Knowledge}

The coaches and teachers in this study were often at odds concerning what counts as relevant knowledge and the location of expertise. Coaches most often valued knowledge of best practices that was produced by experts outside of the school while teachers frequently drew on locally contextualized knowledge and practical experiences within classrooms. The coaches and teachers, however, were not always aware of their own tactical negotiations concerning the consumption and production of knowledge.

Therefore, coaches and teachers may benefit from uncovering the dominant Discourses that influence their work and from opening a dialogue about what counts as relevant knowledge. Such explorations of discursive practice can orient coaches and 
teachers to what Britzman (2003), drawing on Bakhtin, referred to as "the dialogic, a discursive practice that can produce knowledge capable of deconstructing” (p. 230) dominant Discourses. She argued, "Students [and in this case coaches and teachers] can learn how social and historical practices produce and shape what is taken and refused as knowledge" (p. 230). Just as narrative discourse analysis can assist teachers in analyzing their interactions with students (Juzwik \& Ives, 2010), microethnographic discourse analysis may be a constructive way for coaches and teachers to analyze their interactions and to develop an understanding that knowledge is co-constructed. The coaches and teachers in this study were not interested in engaging in such analysis, largely due to time constraints. Such analysis could, however, be plausible within university-based preparation programs for literacy coaches and district-supported professional development engagements.

Furthermore, I encourage literacy coaches, teachers, administrators, and policy makers to question the effectiveness of redelivery models of coaching, which focus on training for the implementation of particular instructional practices. As I have illustrated in this study, best practices had varied meanings for each participant, and teachers appropriated best practices for their own intents and purposes. More importantly, attempts to control teachers' implementation of particular methods resulted in missed opportunities for meaningful professional inquiry and collaboration. Literacy coaching spaces that enable coaches and teachers to work together to evaluate, choose, and define best practices have greater transformative potential. As Hargreaves \& Dawe (1990) argued, best practices... 
are not merely different technical procedures to be selected according to their proven efficiency or inefficiency. They embody particular and disputable educational purposes, they suit teachers with particular kinds of personality and educational beliefs, and they are more appropriate for some contexts than others. (p. 236)

As such, it is critical that coaches and teachers have opportunities to define what counts as relevant knowledge for themselves and their students within their unique contexts, using outside expertise as a guide rather than as a dictate (Davies, 2003; Hargreaves, 1991). Coaches and teachers should be "key players in the creation of new knowledge" (Sugrue, 2008, p. 87) within spaces that value various ways of knowing and allow for teacher inquiry and research (Cochran-Smith \& Lytle, 2006). Within such spaces, coaches might act as advocates for teachers' knowledge production rather than as supporters of the uncritical consumption of particular methods.

Such work requires coaches, administrators, and policy makers to avoid "technicizing teacher knowledge" (Fenwick, 2003, p. 351), or reducing the goals of professional learning to the implementation of particular practices or alignment to standards (Britzman, 2007; Fenwick, 2003; Lofthouse \& Leat, 2013). Instead, they can work to develop dialogic inquiry spaces for coaches and teachers (Crafton \& Kaiser, 2011; Jewett \& MacPhee, 2012) in which they collaboratively experiment with classroom practices, engage in deep conversation and educational theory, and challenge one another's beliefs (Lofthouse \& Leat, 2013). Within these spaces, coaches and teachers might also engage in "critical identity work" (MacPhee, 2013, p. 321), negotiation of the 
curriculum (Crafton \& Kaiser), and discussions of power and positioning (Hunt \& Handsfield, 2013).

\section{Development as Breaking Away}

Within the context of this study, the dominant view of teacher development was as a linear, hierarchical, step-wise progression towards the implementation of best practices. The end goal of this development was nonnegotiable and universal in the sense that it teachers were expected to implement best practices in a particular way. There are, however, other possibilities for understanding development. If coaches and teachers are active producers of knowledge, they can determine their own trajectories. They can become "poets of their own acts, silent discoverers of their own paths in the jungle of functionalist rationality" (de Certeau, 1984, p. xviii). In this sense, development is viewed as a "breaking away" (Engeström, 1996, p. 126), as “opening toward new possibilities that cannot be determined in advance" (Leander \& Boldt, 2013, p. 32). For coaches, this view of development means shifting from a focus on the implementation of particular best practices to collaboratively "asking questions such as why are changes in this direction good, good for whom, good at whose and at what expense, what are the limits of these benefits and so forth" (Matusov et al., 2007, p. 403). Moreover, such a shift requires that the goals of development are not taken for granted but are evaluated in terms of shared values and concerns (Matusov et al., 2007) and the coaches' and teachers' beliefs, values, personal knowledge, and identities (MacPhee, 2013).

The coaches and teachers were also heavily influenced by a Vygotskian (1978) sociocultural view of child development in which learners are guided through the zone of proximal development (ZPD) by a more knowledgeable other. As I explained in detail 
earlier, Vygotsky's developmental theories have made a highly valuable contribution to the field of education, and his views of learning as socially mediated are important for understanding how coaches and teachers co-construct meaning. However, as several other researchers have noted (Dyson, 1999; Smagorinsky, 2011; Rogoff, 1990; Roth \& Radford, 2010; Matusov, 1998; Moll, 1990; Searle, 1992), the concept of ZPD, when interpreted in simplistic terms, positions learners as deficient, teachers (or in this case, coaches) as experts, and learning as a dyadic process of transmitting pre-existing cultural understandings. Despite these limitations, it is possible for literacy coaches to act from an expanded view of ZPD as "situated development" (Smagorinsky, 2011, p. 56), one that understands the ZPD "not only as zones of agreement but also of tensions, disagreements, misunderstandings, conflict and subversion" (Roth \& Radford, 2010, p. 306). From such an expanded view, literacy coaches may act as "a knowledgeable and supportive other" (MacPhee, 2013, p.321) rather than as a more knowledgeable other and, thus, more fully acknowledge and value teachers' contributions to knowledge production and instructional decision making. This stance does not completely alleviate tensions over who gets to be the expert and what counts as relevant knowledge, nor does it erase the influences of dominant Discourses. However, this small shift in thinking could be a starting point for more symmetrical interactions in which teachers' ways of knowing and understanding have greater weight.

\section{Trust within Spaces of Discomfort and Ambiguity}

The literacy coaches in this study worked hard to establish credibility, which was achieved, in part, by gaining the trust of the teachers. The teachers trusted the coaches not to be pushy or make them feel stupid. This trust, as established within Discourses of best 
practice and development, was partially defined by collaborative norms of "making nice" (Evans, 2001) and staying within the parameters of local understandings of the most effective workshop methods. This sort of trust does not align well with notions of development as breaking away into something new as described above. In order to promote more transformative professional development, literacy coaches may need to develop a more robust sense of trust that "allows people to be more honest about themselves and their practice and to be prepared to engage in dialogue" (Lofthouse \& Leat, 2013, p. 15). A first step towards this goal may be to openly acknowledge the power relations that are inherent in the relationships between coaches and teachers. It may not be enough for coaches to simply take a co-learner stance because structural conditions and the cultural histories of schools make power differentials apparent and, as such, they are felt by teachers regardless of coaches' desire to be seen as unthreatening and nonjudgmental.

Furthermore, it is critical for coaches and teachers to have a safe space where they can wrestle with the ambiguities and uncertainties of professional learning. As Lofthouse and Leat (2013) argued, it can be difficult to build such spaces in the current educational climate with its heavy emphasis on standards, best practices, and highly qualified teachers. It may first be necessary for policy makers and administrators to support and encourage professional learning that values local, contextualized, and emotional ways of knowing. With proper institutional supports, coaches can employ certain "moves" (Jewett $\&$ MacPhee, 2012, p. 17) that engender trust such as active listening, using positive language, focusing on student learning, and avoiding judgment (Jewett \& MacPhee, 2012; Lofthouse \& Leat, 2013; Mangin \& Stoelinga, 2011; Matsumura et al., 2010). It is 
important to note, however, that such moves do not remove issues of power and positioning, and so it is also vital to openly acknowledge and discuss them.

\section{Emotional Ways of Knowing}

My findings suggest that literacy coaches and other educators may benefit from paying attention to emotions, to the "plural mobility of goals and desires" (de Certeau, 1984, p. xxii) that are always and necessarily present within their work and interactions. As Lemke (2012) argued, "Every literate practice is always also an affective experience, and how we feel about an event, meaning or action plays a critical role in co-determining our next action, the next meaning" (p. 58). In other words, emotions play a critical role in the co-construction of knowledge, and as such, they influence coaches' and teachers' understandings of themselves, each other, and their work. Despite the prominence of emotions, the literacy coaches and teachers in this study rarely acknowledged them explicitly, and only positive emotions were readily accepted. Although they were often unaware of the ways in which they used emotions, they were still an important part of their discursive positionings. As such, literacy coaches and teachers may benefit from bringing their emotions and the "emotional rules" of their learning community to the level of conscious awareness. Such awareness may help to create transformative spaces, where emotional ways of understanding and knowing are equally relevant to dominant Discourses of rationality.

The most prevalent emotional experience in this study revolved around a condition of professional vulnerability that encouraged feelings of shame, guilt, and fear. This type of vulnerability is common in today's educational climate, which draws on market Discourses to conceptualize teachers as technicians who must be held accountable 
to a particular set of professional standards and practices. Within such conditions of vulnerability, it was difficult for coaches and teachers to move beyond their concerns about maintaining an image as a "good" teacher or coach. Therefore, it is important to improve educators' working conditions so that they may safely and freely apply their professional judgment based on multiple ways of knowing and understanding. As Hargreaves (1998) argued, "It is absolutely vital that teachers are given the basic security of being trusted and valued...so that they are not afraid to fail, and are keen and ready to experiment, to take risks, and to try new approaches which support the moral purposes they pursue together" (p. 326).

I acknowledge that it is difficult to move past these conditions of vulnerability given the current high-stakes climate of education in which teachers are under increasing scrutiny and pressure to comply with "best practices" and "high standards." It is likely that many coaches and teachers will be working in schools and districts that strongly emphasize particular instructional programs and methods. However, coaches may still trust and value teachers and their ways of knowing by carefully choosing their focusing points and questions within coaching interactions. For instance, when teachers in this study were in conflict with district initiatives for best practice, the coaches often attempted to redirect them towards particular ways of doing, understanding, or believing. Alternatively, literacy coaches may value teachers' ways of knowing by actively listening to teachers' explanations for their instructional decisions and engaging in deep discussions about how those decisions intersected with their identities, personal beliefs, and educational theory. 


\section{Implications for Research}

In addition to the practical implications listed above, my findings point to implications for research in literacy coaching and for research employing microethnographic approaches to discourse analysis. For instance, the field of literacy coaching research may benefit from employing a wider variety of theoretical frames and further exploring issues of power, positioning, and identity. Microethnographic research could be enhanced by examinations of how the technical details of video recording affect data generation and by the inclusion of emotions in the microanalysis of social interactions.

\section{Research on Literacy Coaching}

As I highlighted in Chapter Two, much of the research on literacy coaching relies on underdeveloped theoretical frameworks or is atheoretical. Such research focuses on the roles and responsibilities of literacy coaches and deemphasizes the political nature of their daily work. Another large body of literacy coaching research relies on sociocultural philosophies based in Vygotsky’s (1962) research (Biancarosa et al., 2010; Blackstone, 2007; Casey, 2006; Collet 2012; McLean et al., 2012; Stover et al., 2011) and most often neglects issues of identity, power, and positioning. Only a few researchers (Coburn \& Woulfin, 2012; Hargreaves \& Skelton, 2012; Hunt \& Handsfield, 2013; MacGillivray et al., 2004; Mangin \& Dunsmore, 2013; Rainville \& Jones, 2008; Stevens \& Hinchman, 2011) have begun to explore literacy coaching through other theoretical lenses that may begin to address the complexities of literacy coaching.

There are many underexplored theoretical frames that hold great possibility for exploring the complex work of literacy coaches. Further research from a poststructuralist 
perspective has the potential to address the political nature of literacy coaching because of its attention to Discourse, power, and agency. Work by feminist poststructuralists such as Britzman (2003) and Boler (1999) may be particularly fruitful due to their attention to emotion, alternate ways of knowing, and view of power as "power with" rather than "power over" (Bloome et al., 2005, p. 154). In a similar vein, there is a large body of work on teacher emotion (Boler, 1999; Hargreaves, 2001; Keltchermens, 2005; Lasky, 2005; Zembylas, 2005) that can help researchers make sense of literacy coaching and professional learning. Furthermore, Cultural Historical Activity Theory (Engeström, 1996) may be helpful to researchers because it extends sociocultural theory, in which coaching has strong roots, to include issues of power and identity (Lewis et al., 2007), and there is some promising work in that direction (Lofthouse \& Leat, 2013). Finally, there is a large body of work on continuing professional development (CPD) (Day \& Gu, 2010; Elmore, 2002; Hargreaves, 1998) that is highly relevant to literacy coaching because of its focus on developing a shared vision for professional learning among all stake holders

Since literacy coaching is highly contextualized, there is a need to analyze coaching interactions that consist of different kinds of positionings. In my analysis, coaches and teachers were often positioned in ways that prioritized coaches' expert knowledge of best practices and deemphasized teachers' contextual, classroom knowledge. This sort of assymetrical positioning is not inevitable, however, and it would be beneficial to explore literacy coaching interactions in which coaches and teachers position themselves as more collaborative equals within school cultures that promote critical professional inquiry. It may also be valuable to explore how literacy coaches and 
teachers in other contexts are constrained by similar dominant Discourses of best practices and development or other Discourses. Additionally, we need further exploration into how literacy coaches and teachers resist dominant Discourses and achieve a level of agency in their professional learning. As de Certeau (1984) argued, "If it is true that the rid of 'discipline' is everywhere becoming clearer and more extensive, it is all the more urgent to discover how an entire society resists being reduced to it" (de Certeau, 1984, p. xiv).

\section{Microethnographic Research}

As I explained above, the act of video recording influences data generation. The presence of the camera, participants' interactions with it, and technical considerations affect what the researcher sees. Microethnographic analysis of video data requires complex decisions such as how the footage is shot, how to choose video clips for analysis, and how to transcribe the video (Erickson, 2011). While the complexity of video-generated data has been explored by a few researchers (Baker \& Green, 2007; Bezermer \& Mavers, 2011; Derry et al, 2010; Erickson, 2011; Lomax et al., 2011), the field of microethnographic research could benefit from further explorations of how the details of video recording affect what is made visible to the researcher.

Furthermore, microethnographic discourse analysis would likely be enhanced by the inclusion of emotions. Since emotion "circulates and, in the process, produces identities and transforms signs" (Lewis \& Tierney, 2013), any study of how people coconstruct meaning and/or perform identities is also a study of how they co-construct and do emotion. Close attention to the discursive use of emotions may lead to fuller understandings of how participants position themselves and each other and of particular 
research settings. Moreover, emotions can provide a link between the micro, in-themoment interactions that are the focus of microethnographic research and the larger scale contexts and ideologies in which they occur. This connection is possible because emotions reveal volumes about participants' values, the norms of the community, and how people make sense of their worlds (Lemke, 2012).

\section{Final Thoughts}

I have pointed out several constraining Discourses within the coaching interactions that I observed, and thus, painted a somewhat pessimistic view about the benefits of literacy coaching. However, I remain hopeful about the potential of literacy coaching as a way to enhance professional development, learning, and collaboration in schools. My hope is based in the coaches' and teachers' subtle tactics of resistance and appropriation and in the ways that they managed to insert other ways of knowing and being into the dominant Discourses.

It is worth quoting de Certeau (1984) at length on this matter. Within his philosophy of everyday practices, coaches and teachers can be seen as...

unrecognized producers, poets of their own affairs, trailblazers in the jungles of functionalist rationality" who "trace 'indeterminate trajectories'... sentences that remain unpredictable within the space ordered by the organizing techniques of systems. Although they use as their material the vocabularies of established languages...although they remain within the framework of prescribed syntaxes ... these 'traverses' remain heterogeneous to the systems they infiltrate and in which they sketch out the guileful ruses of different interests and desires. They circulate 
come and go, overflow and drift over an imposed terrain, like the snowy waves of the sea slipping in among the rocks and defiles of an established order. (p. 34) I interpret de Certeau's words as a challenge to literacy coaches and teachers to embrace multiplicities, uncertainties, and ambiguities and to recognize and carve out room for less dominant ways of knowing and being. Instead of acting as intermediaries between policy mandates and teachers, coaches can work with teachers to carve out spaces for tactical resistance. If coaches, teachers, and administrators can create "heterotopias...other spaces for play and invention" in which multiplicity is embraced (Hjorth, 2005, p. 388), they may be able to co-construct new, less constraining Discourses. Where best practices are not taken for granted as indisputable truth, innovation can occur. Where development is conceptualized as nonlinear, nonhierarchical, and dialogical, coaches and teachers can break away from constraining Discourses into something new, into something more. Where there are multiple pathways to becoming and being a "good" teacher, there is freedom from negative vulnerability and opportunities for collaborative risk taking. Where collaboration means being surprised by others, multiple ways of knowing can be honored and incorporated into the system. 


\section{REFERENCES}

Adler, P. A. \& Adler, P. (1998). Observational techniques. In N. K. Denzin \& Y.S. Lincoln (Eds.), Collecting and interpreting qualitative materials (pp. 79-109). Thousand Oaks, CA: Sage Publications.

Aijmer, K. (1997). I think: An English modal particle. Modality in Germanic languages: Historical and Comparative Perspectives, 1(2), 198-225.

Asaf, L. C. (2005). Exploring identities in a reading specialization program. Journal of Literacy Research, 37(2), 201-236.

Auerbach, C., \& Silverstein, L. (2003). Qualitative data: An introduction to coding and analysis. New York: New York University.

Baker, C. (1993). Literacy practices and social relations in classroom reading events. In C. Baker, \& A. Luke (Eds.), The critical sociology of reading pedagogy (pp. 141160). Amsterdam: John Benjamins.

Baker, W. D., Green, J. \& Skukauskaite, A., (2008). Video-Enabled Ethnographic Research: A Microethnographic Perspective. In G. Walford (Ed.), How to do educational ethnography. London: Tufnell Press.

Bakhtin, M. M (1981). Discourse in the novel. In M. Hoquist (Ed.). (C. Emerson \& M. Holquist, Trans.), The dialogic imagination (pp.259-422). Austin: University of Texas Press. (Original work published 1935).

Bakhtin, M.M. (1984). Problems of Dostoevsky's poetics. (C. Emerson, Ed. \& Trans.). Minneapolis, MN: University of Michigan Press.

Bamberg, M. (1997). Language, concepts, and emotions: The role of language in the construction of emotions. Language Sciences, 19(4), 309-340.

Bamberg, M. (2004). Talk, small stories, and adolescent identities. Human Development, 47, 366-369.

Bamberg, M., \& Georgakopoulou, A. (2008). Small stories as a new perspective in narrative and identity analysis. Text \& Talk, 28(3), 377-396). 
Barkhuizen, G. (2009). An extended positioning analysis of a pre-service teacher's better life small story. Applied Linguistics, 31(2), 282-300.

Bartlett, L., Frederick, M., Gulbrandsen, T., \& Murillo, E. (2002). The marketization of education: Public schools for private ends. Anthropology \& Education Quarterly, $33(1), 5-29$.

Barton, D. \& Hamilton, M. (1998). Local literacies Reading and writing in one community. London: Routledge.

Bean, R. M. (2004). The reading specialist: Leadership for the classroom, school, and community. New York: Guilford.

Bean, R. M., Draper. J. A., Hall, V., Vandermolen, J., \& Zigmond, N. (2010). Coaches and coaching in Reading First schools: A reality check. The Elementary School Journal, 111(1), 87-114.

Bean, R. M., Swan, A. L., Knaub, R. (2003). Reading specialists in schools with exemplary reading programs: Functional, versatile, and prepared. The Reading Teacher, 56(5), 446-455.

Beijaard, D., Meijer, P. C., \& Verloop, N. (2004). Reconsidering research on teachers' professional identity. Teaching and Teacher Education, 20, 107-128.

Bell, E., \& Taylor, S. (2003). The elevation of work: Pastoral power and the new age work ethic. Organization, 10(2), 329-349.

Biancarosa, G., Bryk, A. S., \& Dexter, E. (2010). Assessing the value-added effects of Literacy Collaborative professional development on student learning. Elementary School Journal, 111(1), 7-34.

Blachowicz, C., Buhle, R., Ogle D., Frost, S., Correa, A., Kinner, J. D. (2010). Hit the ground running: Ten ideas for supporting and preparing urban literacy coaches. The Reading Teacher, 63(5), 348-359.

Blackstone, P. (2007). The anatomy of coaching: Coaching through storytelling. Journal of Language and Literacy [Online], 3(1), 48-48.

Blamey, K., Meyer, C. K., \& Walpole, S. (2009). Middle and high school literacy coaches: A national survey. Journal of Adolescent and Adult Literacy, 52(4), 310323.

Bloome, D., Carter, S. P., Christian, B. M, Otto, S. \& Shuart-Faris, N. (2005). Discourse analysis and the study of classroom language and literacy events- $A$ microethnographic perspective. New Jersey: Lawrence Erlbaum. 
Boler, M. (1999). Feeling power: Emotions and education. New York, NY: Routledge.

Botzakis, S. (2008). "I've gotten a lot out of reading comics": Poaching and lifelong literacy. In Y. Kim, V. J. Risko, D. L. Compton, D. K. Dickinson, M. K. Hundley, R. T. Jiménez, et al. (Eds.), 57th year- book of the National Reading Conference (pp. 119-129). Oak Creek, WI: National Reading Conference.

Brayboy, B. M. J. (2005). Toward a Tribal critical race theory in education. The Urban Review, 37(5), 425-46.

Britzman, D. P. (1992). The terrible problem of knowing thyself: Toward a poststructural account of teacher identity. Journal of Curriculum Theorizing, 9(3), 23-46.

Britzman, D. P. (2000). Teacher education in the confusion of our times. Journal of Teacher Education, 51(3), 200-205.

Britzman, D. P. (2003). Practice makes practice; a critical study of learning to teach. Albany, NY: Suny Press.

Bucholtz, M. and Hall, K. (2007) Language and Identity, in A. Duranti (Ed.) A Companion to Linguistic Anthropology (369-394). Oxford, UK: Blackwell.

Buell, M., Han, M, Blamey, K. L., \& Vukelich, C. (2010). Facilitating change: Roles of the early childhood literacy coach. Asia-Pacific Journal of Research in Early Childhood Education, 4(2), 29-56.

Bullough, R. V. (2009). Seeking eudaimonia: The emotions in learning. In P. A. Sdhutz \& M. Zembylas (Eds.). Advances in teacher emotion research: The impact on teachers' lives (pp. 33-54). New York: Springer.

Burkins, J., \& Ritchie, S. (2007). Coaches coaching coaches. Journal of Language and Literacy Education, 3(1), 32-47.

Calkins, L. M. (2006). Units of study for teaching writing. Portsmouth, NH: FirstHand.

Calkins, L., Ehrenworth, M., \& Lehman, C. (2012). Pathways to the common core: Accelerating achievement. Portsmouth, NH: Heinemann.

Carspecken, P. F. (1996). Critical ethnography in educational research. New York, NY: Routledge.

Casey, K. (2006). Literacy coaching: The essentials. Portsmouth, NH: Heinemann.

Cazden, C. B. (1988). Classroom Discourse: The language of teaching and learning. Portsmouth, NH: Heinemann. 
Chaiklin, S. (2003). The zone of proximal development in Vygotsky's analysis of learning and instruction. In A. Kozulin, B. Gindis, V. S. Ageyev, \& S. M. Miller (Eds.) Vygotsky's educational theory in cultural context (pp. 39-64). New York, NY: Cambridge University Press.

Chiseri-Strater, E. (1996). Turning in upon ourselves: Positionality, subjectivity, and reflexivity in case study and ethnographic research. In P. Mortensen \& G. Kirsch (Eds.), Ethics and responsibility in qualitative studies of literacy (pp. 115-133). Urbana, IL: NCTE.

Clandinin, D. J., \& Connelly, F. M. (2000). Narative inquiry: Experience and story in qualitative research. San Francisco, CA: Jossey-Bass.

Coates, J. (1983). The semantics of the modal auxiliaries. London: Croom Helm.

Coburn, C. E., \& Woulfin, S. L. (2012). Reading coaches and the relationship between policy and practice. Reading Research Quarterly, 47(1), 5-30.

Cochran-Smith, M., \& Lytle, S. L. (2006). Troubling images of teaching in no child left behind. Harvard Educational Review, 76(4), 668-697.

Coffey, A., \& Atkinson, P. (1996). Making sense of qualitative data. Thousand Oaks, CA: Sage Publications.

Cogan, M. (1973). Clinical supervision. Boston, MA: Houghton Mifflin.

Collet, V. S. (2012). The gradual increase of responsibility model: Coaching for teacher change. Literacy Research and Instruction, 51(1), 27-47.

Collins, P. H. (2000). Black feminist thought. New York, NY: Routledge.

Costa, A. L. \& Garmston, R. J. (1994). Cognitive coaching: A foundation for renaissance schools. Norwood, MA: Christopher-Gordon.

Crafton, L., \& Kaiser, E. (2011). The language of collaboration: Dialogue and identity in teacher professional development. Improving Schools, 14(2), 104-166.

Cresswell, J. W. (2009). Research design: Qualitative, quantitative, and mixed methods approaches. Los Angeles, CA: Sage.

Cross, D. I., \& Hong, J. Y. (2009). Beliefs and professional identity: Critical constructs in examining the impact of reform on the emotional experiences of teachers. In P. A. Sdhutz \& M. Zembylas (Eds.). Advances in teacher emotion research: The impact on teachers' lives (pp. 273-296). New York: Springer. 
Crotty, M. (1999). The foundations of social research: Meaning and perspective in the research process. Thousand Oaks, CA: Sage Publications.

Dall'Alba, G., \& Sandberg, J. (2006). Unveiling professional development: A critical review of stage models. Review of Educational Research, 76(3), 383-412.

Darby, A. (2008). Teachers' emotions in the reconstruction of professional selfunderstanding. Teaching and Teacher Education, 24, 1160-1172.

Davies, B. (2003). Death to critique and dissent? The policies and practices of new managerialism and of 'evidence-based practice'. Gender and Education, 15(1), 91103.

Davies, B., \& Harré, R. (1990). Positioning: The discursive production of selves. Journal for the Theory of Social Behavior, 20(1), 44-63.

Davies, B. \& Harré, R. (1999). Positioning and personhood. In R. Harré \& L. van Langenhove (Eds.), Positioning theory: Moral contexts of intentional actions (pp. 32-52). Oxford: Blackwell.

Day, C., Kington, A., Stobart, G., \& Sammons, P. (2006). The personal and professional selves of teachers: stable and unstable identities. British Educational Research Journal, 32(4), 601-616.

Day, C., \& Gu, Q. (2010). The new lives of teachers. New York, NY: Routledge.

Day, C., \& Qing, G. (2009). Teacher emotions: Well being and effectiveness. . In P. A. Schutz \& M. Zembylas (Eds.). Advances in teacher emotion research (pp. 15-31). New York, NY: Springer.

Day, C., \& Sachs, J. (2004). Professionalism, performativity and empowerment: Discourses in the politics, policies and purposes of continuing professional development. In C. Day \& J. Sachs (Eds.) International handbook on the continuing professional development of teachers (pp. 3-32). Berkshire, England: Open University Press.

De Alba-Johnson, N. F., Rodriguez, M., Arias, L., Johnson, C. Z., McConnell, S., McEvoy, M., Horst, K., \& Passe, A. (2004, April). Is professional training enough? The effect of coaching in the practice of early literacy instruction. Paper presented at the annual meeting of the American Educational Research Association, San Diego, CA.

De Certeau, M. (1997). Culture in the Plural. Minneapolis, MN: University of Minnesota Press. 
de Certeau, M. (1984). The practice of everyday life. Berkeley, CA: University of California Press.

Dehé, N., \& Wichmann, A. (2010). The multifunctionality of epistemic parentheticals in discourse: Prosodic cues to the semantic-pragmatic boundary. Functions of Language, 17(1), 1-28.

Deleuze, G., \& Guattari, P. F. (1987). A thousand plateaus: Capitalism and schizophrenia (Vol. 2). Minneapolis, MN: U of Minnesota Press.

Denzin, N. K. (1984). On understanding emotion. New Brunswick, NJ: Transaction Publishers.

Denzin, N. K. (1989). Interpretive interactionism. Newbury Park, CA: Sage.

Denzin, N., \& Lincoln, Y. (2000). Introduction: The discipline and practice of qualitative research. In N. Denzin \& Y. Lincoln (Eds.), Handbook of qualitative research. Thousand Oaks, California: Sage Publications.

Devos, A. (2010). New teachers, mentoring and the discursive formation of professional identity. Teaching and Teacher Education, 26(5), 1219-1223.

DeWalt, K. M., \& DeWalt, B. R. (2002). Participant observation: A guide for fieldworkers. Walnut Creek, CA: Altamira Press.

Dewey, J. (1933). How we think. Boston, MA: DC Heath.

Dole, J. A. (2004). The changing role of the reading specialist in school reform. The Reading Teacher, 57(5), 462-471.

Dole, J., \& Donaldson, R. (2006). What am I supposed to do all day? Three big ideas for the reading coach. The Reading Teacher, 59(5), 486-488.

Dole, J.A., Liang L.A, Watkins, N.M., \& Wiggins, C.M. (2006). The state of reading professionals in the United States. The Reading Teacher, 60(2), 194-199.

Dowell, M. M. S. (2012). Addressing the complexities of literacy and urban teaching in the USA: Strategic professional development as intervention. Teaching Education, 23(1), 25-50.

Duessen, T., Coskie, T., Robinson, L., \& Autio, E. (2007). “Coach” can mean many things: Five categories of literacy coaches in Reading First. Issues \& Answers. REL 2007-No. 005. Regional Educational Laboratory Northwest.

Dyson, A. H. (1999). Transforming transfer: Unruly children, contrary texts, and the 
persistence of the pedagogical order. Review of Research in Education, 24, 141171.

Dyson, A. H. (2003). The brothers and sisters learn to write: Popular literacies in childhood and school cultures. NY: Teachers College Press.

Eaude, T. (2011). Thinking through pedagogy for primary and early years. Exeter, UK: Learning Matters.

Edwards, R., \& Nicoll, K. (2006). Expertise, competence and reflection in the rhetoric of professional development. British Educational Research Journal, 32(1), 115-131.

Elish-Piper, L. \& L'Allier, S.K. (2010). Exploring the relationship between literacy coaching and student reading achievement in grades K-1. Literacy Research and Instruction, 49, 162-174.

Elmore, R.F. (2002). Bridging the gap between standards and achievement: The imperative for professional development in education. Washington DC: Albert Shanker Institute.

Emerson, R. M., Fretz, R. I., \& Shaw, L. L. (1995). Writing ethnographic fieldnotes. Chicago: The University of Chicago Press.

Engeström, Y. (1996). Development as breaking away and opening up: A challenge to Vygotsky and Piaget. Swiss Journal of Psychology, 55, 126-132.

Engeström, Y. (2005). Developmental work research: Expanding activity theory in practice. Berlin, Germany: Lehmanns Media.

Erickson, F. (1982). Audiovisual records as a primary data source. Sociological Methods and Research, 11(2), 213-232.

Erickson, F. (2004). Talk and social theory: Ecologies of speaking and listening in everyday life. Malden, MA: Polity Press.

Erickson, F. (2011). A history of qualitative inquiry in social and educational research. The Sage Handbook of Qualitative Research, 4, 43-59.

Eaude, T. (2011). Thinking through pedagogy for primary and early years. Exeter, UK: Learning Matters Ltd.

Evans, K. S. (2001). Will you still play with me if I stop making nice? Conflicting discourses in collaborative feminist literacy research. Journal of Literacy Research, 33(1), 99-136. 
Facchinetti, R., \& Adami, E. (2008). Intersubjective patterns of English modalised mental state verbs. English Text Construction, 1(2), 198-225.

Fairclough, N. (1995). Critical discourse analysis. London: Longman.

Fenwick, T. J. (2003). The 'good' teacher in a neo-liberal risk society: a Foucaultian analysis of professional growth plans. Journal of Curriculum Studies, 35(3), 335354.

Ferguson, K. (2011). Examining the relationship of power and resistance in literacy coaching in three school contexts. In P. J. Dunston, L. B. Gambrell, K. Headley, S. K. Fullterton, P. M. Stecker, V. R. Gillis, \& C. C. Bates (Eds.). $60^{\text {th }}$ yearbook of the Literacy Research Association (pp. 165- 178). Oak Creek, Wisconsin: Literacy Research Association, Inc.

Fine, M., \& Weis, L. (Eds.). (2000). Construction sites: excavating class, race, sexuality and gender. New York: Teachers College Press.

Fish, S. (1990). How to recognize a poem when you see one. In D. Bartholomae \& A. Petrosky (Eds.). Ways of reading: An anthology for writers (pp. 178-191). Boston, MA: Bedford Books.

Fishman, B., Marx, R., Best, S., \& Tal, R. (2003). Linking teacher and student learning to improve professional development in systemic reform. Teaching and Teacher Education, 19(6), 643-658.

Foucault, M. (1972). The archaeology of knowledge, New York, NY: Harper and Row.

Foucault, M. (1977). Discipline \& punish. New York, NY: Random House.

Foucault, M. (1980) Power/Knowledge: Selected interviews and other writings, 19721977. New York, NY: Pantheon.

Foucault, M. (1983). The subject and power. In H. Dreyfus \& P. Rabinow (Eds.), Michel Foucault: Beyond structuralism and hermeneutics. Chicago: University of Chicago Press.

Fountain, C. \& Wood, J. (2009). Florida Early Literacy and Learning Model: A systematic approach to improve learning at all levels. Peabody Journal of Education, 75(3), 85-98.

Fountas, I. C., \& Pinnell, G. S. (2001). Guiding readers and writers, Grades 3-6:

Teaching comprehension, genre, and content literacy, Westport, CT: Heinemann. 
Fullan, M. (2011). The six secrets of change: What the best leaders do to help their organizations survive and thrive. San Francisco, CA: Jossey-Bass.

Gardiner, W. (2012). Coaches' and new urban teachers' perceptions of induction coaching: Time, trust, and accelerated learning curves. The Teacher Educator, 47(3), 195-215.

Gee, J. P. (1999). An introduction to discourse analysis theory and method (2nd ed.). New York, NY: Routledge.

Gee, J.P., (2001). Identity as an analytic lens for research in education. In W.G. Secada (Ed.), Review of Research in Education (pp. 99-125). Washington D.C.: American Educational Research Association.

Gee, J. P. (2004). Situated language and learning: A Critique of traditional schooling. London: Routledge.

Gee, J. P. (2007). Social linguistics and literacies: Ideology in discourses. London: Routledge.

Gee. J. P. (2011a). An introduction to discourse analysis ( $2^{\text {nd }}$ ed.). New York: Routledge.

Gee, J. P. (2011b). How to do discourse analysis: A toolkit. New York: Routledge.

Gee. J. P. (2012). Social linguistics and literacies $\left(4^{\text {th }}\right.$ ed.). New York: Routledge.

Geertz, C. (1973). Thick description: Toward an interpretive theory of culture. In C. Geertz (Ed.), The interpretation of cultures (pp. 3-30). New York: Basic Books.

Gibson, S. A. (2006). Lesson observation and feedback: The practice of an expert reading coach. Literacy Research and Instruction, 45(4), 295-318.

Glaser, B. G., \& Strauss, A. L. (1967). The discovery of grounded theory. Chicago: Aldine.

Glazer, M. (1982). The threat of the stranger: Vulnerability, reciprocity, and fieldwork. In J.Sieber (Ed.), Ethics of Social Research: Fieldwork, Regulation, and Publication (pp. 49-70).New York: Springer-Verlag.

Glesne (2006). Becoming qualitative researchers: An introduction. Boston, MA: Pearson. Goldhammer, R. (1969). Clinical supervision: Special methods for the supervision of teachers. New York: Holt, Rinehart, and Winston.

Goffman, E. (1967). Interaction ritual: essays on face-to-face interaction. New York: Doubleday Anchor. 
Goffman, E. (1976). Replies and Responses. Language in Society, 5, 257-313.

Goffman, E. (1981). Forms of talk. Philadelphia, PA: University of Pennsylvania Press.

Goldhammer, R. (1969). Clinical supervision: Special methods for the supervision of teachers. New York, NY: Holt, Rinehart and Wilson.

Goldrick, L., Osta, D., \& Maddock, A. (2010). Race to the top: Phase two: Teacher induction and teaching and learning conditions. The New Teacher Center, 1-10.

Graves, D. H. (1983). Writing: Teachers and children at work. Exeter, NH: Heinemann Educational Books.

Green, J. L., \& Wallat, C. (1981). Mapping instructional conversations. In J.L. Green \& C. Wallat (Eds.), Ethnography and language in educational settings (pp. 161195). Norwood, NJ: Ablex.

Grossman, P. L. (1992). Why models matter: An alternate view on professional growth in teaching. Review of Educational Research, 62(2), 171-179.

Gumperz, J. J. (Ed.). (1986). Discourse strategies .Cambridge University Press.

Gumperz, J. J. \& Berenz, N. (1993). Transcribing conversational exchanges. In Jane Edwards \& Martin Lampert (Eds.), Talking data: Transcription and coding methods for language research (pp. 91-122). Hillsdale, NJ: Lawrence Erlbaum Associates.

Gunthner, S., 1997. The contextualization of affect in reported dialogues. In: Niemeier, S., Dirven, R. (Eds.), The language of emotions: Conceptualization, expression, and theoretical foundation. Philadelphia, PA: John Benjamins Publishing, pp. 247-275.

Gutiérrez, K. D., Larson, J., Enciso, P., \& Ryan, C. L. (2007). Discussing expanded spaces for learning. Language Arts, 85(1), 69.

Handsfield, L. J., Crumpler, T.P., \& Dean, T. R. (2010). Tactical negotiations and creative adaptations: The discursive production of literacy curriculum and teacher identities across space-times. Reading Research Quarterly 2 45(4), 405-431.

Hargreaves, A. (1998). The emotional politics of teaching and teacher development: with implications for educational leadership. International Journal of Leadership in Education Theory and Practice, 1(4), 315-336.

Hargreaves, A. (2001). Emotional geographies of teaching. Teachers College Record, 103(6), 1056-1080. 
Hargreaves, A. (2003). Teaching in the knowledge society: Education in the age of insecurity. New York, NY: Teachers College Press.

Hargreaves, A., \& Dawe, R. (1990). Paths of professional development: Contrived congeniality, collaborative culture, and the case of peer coaching. Teaching \& Teacher Education, 6(3), 227-241.

Hargreaves, A., \& Skelton, J. (2012). Politics and systems of coaching and mentoring. In S. Fletcher, \& C. A. Mullen (Eds.) The SAGE Handbook of Mentoring and Coaching in Education (pp. 122-138). Thousand Oaks, CA: Sage.

Harré, R. (1986). The social construction of emotions. New York: Basil Blackwell.

Harré, R. (2010). Foreward. In M. B. McVee, C. H. Brock, \& J. A. Glazier (Eds.). Sociocultural positioning in literacy: Exploring culture, discourse, narrative, and power in diverse educational contexts (pp. ix-xi). Cresskill, NJ: Hampton Press, Inc.

Harré, R., \& Moghaddam, F. (2003). Introduction: The self and other in traditional psychology and in positioning theory. In R. Harré \& F. Moghaddam (Eds.), The self and others (pp. 1-11). Westport, CT: Praeger.

Harré, R. \& Van Langenhove, L. (Eds.) (1999). Positioning Theory: Moral Contexts of Intentional Action. Malden: Blackwell.

Hartnett, S. (1998). Michel de Certeau's critical historiography and the rhetoric of maps. Philosophy and Rhetoric, 31(4), 283- 302.

Harrison, J., MacGibbon, L., \& Morton, M. (2001). Regimes of trustworthiness in qualitative research: The rigors of reciprocity. Qualitative Inquiry, 7(3), 323-345.

Haviland-Jones, J. M ., \& Kahlbaugh, P. (2000). Emotion and identity. In M. Lewis \& J. M. Haviland-Jones (Eds.). Handbook of emotions, $2^{\text {nd }}$ edition (pp. 293-305). New York: The Guilford Press.

Hawley, W. D., \& Valli, L. (1999). The essentials of effective professional development: A new consensus. In L. Darling-Hammond \& G. Sykes (Eds.), Teaching as the learning profession: Handbook of policy and practice (pp. 127- 150). San Francisco, CA: Jossey-Bass.

Hays, L. \& Davis-Harris, C. (2003). Using literacy coaching as a means to change science teachers' attitudes about teaching writing: A case study. Electronic Journal of Literacy through Science, 6(2), n.p.

Heath, S. B. (1983). Ways with words. New York: Cambridge University Press. 
Herron-Hruby, A., Hagood, M.C., \& Alvermann, D.E. (2008). Switching places and looking to adolescents for the practices that shape school literacies. Reading \& Writing Quarterly, 24(3), 311-334.

Heylen, D., \& op den Akker, R. (2006). Investigations into the distribution of back-channels in argumentative multi-party discourse and their functional determinants. Manuscript, HMI Research group, University of Twente. Retrieved from http://www.memetic-vre.net/MMAD/MMAD2206Heyleyn+Akker.pdf.

Hibbert, K. M., Heydon, R. M., \& Rich, S. J. (2008). Beacons of light, rays, or sun catchers? A case study of the positioning of literacy teachers and their knowledge in neoliberal times. Teaching and Teacher Education, 24, 303- 315.

Hirst, E. (2004). Diverse social contexts of a second-language classroom and the construction of identity. In K. M. Leander \& M. Sheehy (Eds.), Spatializing literacy research (pp. 39-66). New York: Peter Lang.

Hjorth, D. (2005). Organizational entrepreneurship with de Certeau on creating heterotopias (or spaces for play). Journal of Management Inquiry, 14(4), 386-398.

Hoffman, J. \& Pearson, J. D. (2000). Reading teacher education in the next millennium: What your grandmother's teacher didn't know that you granddaughter's should. Reading Research Quarterly, 35(1), 29-44.

Holland, D.,Lachicotte.W., Skinner, D., \& Cain, C. (1998) Identity and agency in cultural worlds. Cambridge, MA: Harvard University Press.

Holmes, J. (1990). Hedges and boosters in women's and men's speech. Language \& Communication, 10(3), 185-205.

Hyslop-Margison, E. J., \& Sears, A. M. (2010). Enhancing teacher performance: The role of professional autonomy. Interchange, 41(1), 1-15.

Hsieh, W. J., Hemmeter, M. L., McCollum, J. A., Ostrosky, M. M. (2009). Using coaching to increase preschool teachers' use of emergent teaching strategies. Early Childhood Research Quarterly, 24, 229-247.

Hunt, C. S., \& Handsfield, L. J. (2013). The emotional landscapes of literacy coaching: Issues of identity, power, and positioning. Journal of Literacy Research, 43(1), 47-86.

Hymes, D. (1996). Ethnography, linguistics, narrative inequality: Toward an understanding of voice. London: Taylor \& Francis. 
Ippolito, J. (2010). Three ways that literacy coaches balance responsive and directive relationships with teachers. The Elementary School Journal, 111(1), 164-190.

International Reading Association. (2004). The role and qualifications of the reading coach in the United States: A position statement of the International Reading Association. Newark, Delaware.

Jaworski, A., \& Coupland, N. (1999). Introduction: Perspectives on discourse analysis. In A. Jaworski \& N. Coupland (Eds.), The Discourse Reader (pp. 1-44). London: Routledge.

Jewett, P., \& MacPhee, D. (2012). A dialogic conception of learning: collaborative peer coaching. International Journal of Mentoring and Coaching in Education, 1(1), $12-23$.

Johnson, R. B., \& Christensen, L. B. (2004). Educational research: Quantitative, qualitative, and mixed approaches. Boston, MA: Allyn and Bacon.

Johnston, P. H. (2004). Choice words: How our language affects children's learning. Portland, ME: Stenhouse.

Jones, T., Barksdale, M. A., Triplett, C. F., Potts, A., Lalik, R., \& Smith, C. (2010). Complexities in the Roles of Reading Specialists. International Journal of Education, $2(2), 1-21$.

Joyce, B., \& Showers, B. (1980). Improving inservice training: The message of research. Educational Leadership, 37(5), 379.

Joyce, B. \& Showers, B. (2002). Student achievement through staff development, $3^{\text {rd }}$ edition. Alexandria, VA: ASCD.

Jucker, A. H. (1993). The discourse marker well: A relevance-theoretical account. Journal of Pragmatics, 19(5), 435-452.

Juzwik. M. M., \& Ives, D. (2010). Small stories as resources for performing teacher identity: Identity-in-interaction in an urban language arts classroom. Narrative Inquiry, 20(1), 37-61.

Kaltenböck, G. (2009). Initial I think: main or comment clause?. Discourse and Interaction, 2(1), 49-70.

Kamberelis, G., \& Dimitriadis, G. (2005). On qualitative inquiry. New York: Teachers College Press, Columbia University. 
Kamberelis, G., \& Scott, K. D. (1992). Other people's voices: The coarticulation of texts and subjectivities. Linguistics and Education, 4, 359-403.

Kawulich, B. B. (2005). Participant observation as a data collection method. Forum: Qualitative Social Research, 6(2), 43.

Kelchtermans, G. (2005). Teachers' emotions in educational reforms: Self-understanding, vulnerable commitment and micropolitical literacy. Teaching and Teacher Education, 21(8), 995-1006.

Kennedy, E. \& Shiel, G. (2010). Raising literacy levels with collaborative on-site professional development in an urban disadvantaged school. The Reading Teacher, 63(5), 372-383.

Kim, M. (2012). Intertextuality and narrative practices of young deaf students in classroom contexts: A microethnographic study. Reading Research Quarterly, 47(4), 404-426.

Kissel, B., Mraz, M., Algozzine, R., \& Stover, K. (2011). Early literacy coaches' role perceptions and recommendations for change. Journal of Research in Childhood Education, 25(3), 288-303.

Kleinman, S. (1991). Experiencing fieldwork. Newbury Park, CA: Sage.

Knight, J. (1994). Instructional coaches make progress through partnership: Intensive support can improve teaching. Journal of Staff Development, 25(2), 32-37.

Kretlow, A. G., Wood, C. L., \& Cooke, N. L. (2011). Using in-service and coaching to increase Kindergarten teachers' accurate delivery of group instructional units. The Journal of Special Education, 44(4), 234-246.

Kristeva, J. (1980). Desire in language: A semiotic approach to literature and art. Oxford: Blackwell.

Lapadat, J. C., \& Lindsay, A. C. (1999). Transcription in research and practice: From standardization of technique to interpretive positionings. Qualitative Inquiry, 5(1), 64-86.

L'Allier, S. K., Elish-Piper, L., \& Bean, R. M. (2010). What matters for elementary literacy coaching? Guiding principles for instructional improvement and student achievement. The Reading Teacher, 63, 544-554.

Lasky, S. (2005). A sociocultural approach to understanding teacher identity, agency and professional vulnerability in a context of secondary school reform. Teaching and teacher education, 21(8), 899-916. 
Larson, J., \& Gatto, L.A. (2004). Tactical underlife: Understanding students' perceptions. Journal of Early Childhood Literacy, 4(1), 11-41.

Lather, P. (1991) Getting smart: Feminist research and pedagogy with/in the postmodern. New York: Routledge.

Lave, J., \& Wenger, E. (1991) Situated Learning: Legitimate peripheral participation Cambridge, UK: Cambridge University Press.

LeBaron, C. (2005). Considering the social and material surround: Toward microethnographic understandings of nonverbal behavior. In V. Manusov (Ed.), The sourcebook of nonverbal measure (pp. 493-506). Mahwah, NJ: Erlbaum.

Leander, K. M. (2002). Locating Latanya: The Situated Production of Identity Artifacts in Classroom Interaction. Research in the Teaching of English, 37, 198-250.

Leander, K. M. (2004). "They took out the wrong context": Uses of time-space in the practice of positioning. ETHOS, 32, 188-213.

Leander, K., \& Boldt, G. (2013). Rereading “A Pedagogy of Multiliteracies”: Bodies, texts, and emergence. Journal of Literacy Research, 45(1), 22-46.

Leander, K., \& Wells Rowe, D. (2006). Mapping literacy spaces in motion: A rhizomatic analysis of a classroom literacy performance. Reading Research Quarterly, 41(4), $428-460$.

Lefebvre H. (1974). The production of space. Oxford: Blackwell.

Lemke, J. L. (1992). Intertextuality and educational research. Linguistics and Education, 4, 257-267.

Lemke, J. L. (2012). Thinking about feeling: Affect across literacies and lives. In O. Erstad, \& J. Sefton-Green (Eds.) Learning lives: Transactions, technologies, and learner identity. (pp. 57-69). Cambridge, UK: Cambridge University Press.

Lewis, C., Enciso, P., \& Moje, E. B. (2007). Introduction: Reframing sociocultural research on literacy. In C. Lewis, P., Enciso, \& E. B., Moje (Eds.), Reframing sociocultural research on literacy: Identity, agency, and power (pp. 1-11). Mahwah, NJ: Lawrence Erlbaum Associates.

Lewis, C., \& Tierney, J. D. (2011). Mobilizing emotion in an urban English classroom. Changing English, 18(3), 319-329.

Lincoln, Y. S., \& Guba, E. G. (2000). Paradigmatic controversies, con-tradictions, and 
emerging confluences. In N. K. Denzin, and Y. S. Lincoln (Eds.), Handbook of qualitative research (pp. 163-188). Thou-sand Oaks, CA: Sage.

Lockwood, J. R., McCombs, J. S., \& Marsh, J. (2010). Linking reading coaches and student achievement: Evidence from Florida middle schools. Educational Evaluation and Policy, 32(3), 372-388.

Lofthouse, R., \& Leat, D. (2013). An activity theory perspective on peer coaching. International Journal of Mentoring and Coaching in Education, 2(1), 8-20.

Luttrell, W. (2003). Pregnant bodies, fertile minds. New York: Routledge.

Lynch, J. \& Ferguson, K. (2010). Reflections of elementary school literacy coaches on practice: Roles and perspectives. Canadian Journal of Education, 33(1), 199-277.

MacGillivray, L., Ardell, A. L., Curwen, M. S., Palma, J. (2004). Colonized teachers: Examining the implementation of a scripted reading program. Teaching Education, 15(2), 131-144.

MacLure, M. (1993). Arguing for your self: Identity as an organising principle in teachers' jobs and lives. British Educational Research Journal, 19(4), 311-322.

MacPhee, D. A. (2013). Professional development as the study of self: Using selfknowledge to mediate the act of teaching. In P. J. Dunston \& S. K. Fullerton (Eds.) $62^{\text {nd }}$ Yearbook of the Literacy Research Association (pp. 311-323).

Mangin, M. M., \& Dunsmore, K. (2013). Conflicting storylines in teacher leadership: How one literacy coach struggled to position herself and her work. The New Educator, 9(3), 226-248.

Mangin, M. M., \& Stoelinga, S. R. (2011). Peer? Expert? Teacher Leaders Struggle to Gain Trust While Establishing Their Expertise. Journal of Staff Development, $32(3), 48-51$.

Marsh, J. A., Sloan-McCombs, J., Lockwood, J. R., Martorell, F., Gershwin, D., Naftel, S., Vi-Nhuan, L., Shea, M., Barney, H., \& Crego, A. (2008). Supporting literacy across the Sunshine State: A study of Florida middle school reading coaches. Santa Monica, CA: The RAND Corporation.

Marsh, J. A., McCombs, J. S., \& Martorell, F. (2010). How instructional coaches support data-driven decision making. Educational Policy, 24(6), 872-907.

Marsh, J. A., McCombs, J. S., \& Martorell, F. (2012). Reading coach quality: Findings from Florida middle schools. Literacy Research and Instruction, 51(1), 1-26. 
Matsumura, L.K., Garnier, H.E., Correnti, R., Junker, B., Bickel, D.D. (2010). Investigating the effectiveness of a comprehensive literacy coaching program in schools with high teacher mobility. The Elementary School Journal, 111(1), 3562.

Matusov, E. (1998). When solo activity is not privileged: Participation and internalization models of development. Human Development, 41(5-6), 326-349.

Matusov, E. (2011). Irreconcilable differences in Vygotsky's and Bakhtin's approaches to the social and the individual: An educational perspective. Culture \& Psychology, 17(1), 99-119.

Matusov, E., DePalma, R., \& Drye, S. (2007). Whose development? Salvaging the concept of development within a sociocultural approach to education. Educational Theory, 57(4), 403-421.

Matusov, E., \& Hayes, R. (2000). Sociocultural critique of Piaget and Vygotsky. New Ideas in Psychology, 18(2), 215-239.

McLean, C. A., Mallozzi, C.A., Hu, R., Dailey, L.B. (2010). Literacy coaching and Reading First "redelivery": a discourse analysis. Teacher Development, 14(2), 253-268.

McClave, E. Z. (2000). Linguistic functions of head movements in the context of speech. Journal of Pragmatics, 32(7), 855-878.

McKenna, M. C., \& Walpole, S. (2008). The literacy coaching challenge: Models and methods for grades $K-8$. New York: The Guilford Press.

McKinney, M., \& Giorgis, C. (2009). Narrating and performing identity: Literacy specialist's writing identities. Journal of Literacy Research, 41, 104-149.

McVee, M. B. (2010). Positioning theory and sociocultural perspectives: Affordances for educational researchers. In M. B. McVee, C. H. Brock, \& J. A. Glazier (Eds.). Sociocultural positioning in literacy: Exploring culture, discourse, narrative, and power in diverse educational contexts (pp. 1-21). Cresskill, NJ: Hampton Press, Inc.

McWilliam, E. (1994). In broken images: Feminist tales for a different teacher education. New York: Teachers College Press.

McWilliam, E. (2002). Against professional development. Educational Philosophy and Theory, 34(3), 289-299.

Mehan, H. (1979). Learning lessons. Cambridge: Harvard University Press. 
Merriam, S. B. (1995). What can you tell from an $\mathrm{N}$ of 1?: Issues of validity and reliability in qualitative research. PAACE Journal of Lifelong Learning, 4, 51-60.

Merriam, S. B. (Ed.). (2002). Qualitative research in practice: Examples for discussion and analysis. San Francisco: Jossey-Bass.

Mertens, D. (1998). Research methods in education and psychology: Integrating diversity with quantitative and qualitative approaches. Thousand Oaks, CA, Sage.

Meyer, D. K. (2009). Entering the emotional practices of teaching. In P. A. Schutz \& M. Zembylas (Eds.). Advances in teacher emotion research: The impact on teachers' lives (pp. 73-91.). New York: Springer.

Moje, E. (2004). Powerful spaces: Tracing the out-of-school literacy spaces of Latino/a youth. In K. M. Leander \& M. Sheehy (Eds.), Spatializing literacy research and practice (pp. 15-38). New York, NY: Peter Lang.

Moje, E. B. \& Luke, A. (2009). Literacy and identity: Examining the metaphors in history and contemporary research. Reading Research Quarterly, 44(4), 415-437.

Moll, L. C. (1990). Vygotski's Zone of Proximal Development: Rethinking its instructional implications. Infancia y Aprendizaje: Journal for the Study of Education and Development, (51), 157-168.

Morgan. D. N., Saylor-Crowder, K., Stephens, D., Donnelly, A., DeFord, D. E., \& Hamel, E. (2003). Managing the complexities of a state-wide initiative. Phi Delta Kappan, 85(2), 139-144.

Mraz, M., Algozzine, B., \& Watson, P. (2008). Perceptions and expectations of roles and responsibilities of literacy coaching. Literacy Research and Instruction, 47(3), $141-157$.

Mraz, M., Kissel, B., Algozzine, B., Babb, J., \& Foxworth, K. (2011). A collaborative professional development initiative supporting early literacy coaches. NHSA Dialog, 14(3), 1-11.

Neufeld, B. \& Roper, D. (2003). Coaching : A strategy for developing instructional capacity. Washington, D.C.: Aspen Institute.

Neuman, S. B., \& Cunningham, L. (2009). The impact of professional development and coaching on early language and literacy instructional practices. American Educational Research Journal, 46(2), 532-566.

Neuman, S. B., \& Wright, T. S. (2010). Promoting language and literacy development for 
early childhood educators: A mixed-methods study of coursework and coaching. The Elementary School Journal, 111(1), 63-86.

Newmann, F. M., King, M. B., \& Youngs, P. (2000). Professional development that addresses school capacity: Lessons from urban schools. American Journal of Education, 108, 259-299.

No Child Left Behind (NCLB) Act of 2001, Pub. L. No. 107-110, § 115, Stat. 1425 (2002).

Ochs, E. (1979). Transcription as a theory. In E. Ochs \& B. Schieffelin (Eds). Developmental pragmatics. New York: Academic Press.

Ogden, R. (2006). Phonetics and social action in agreements and disagreements. Journal of Pragmatics, 38(10), 1752-1755.

Otaiba, S. A., Hosp, J. L., Smartt, S., \& Dole, J. A. (2008). The challenging role of a reading coach: A cautionary tale. Educational and Psychology Consultation, 18, 124-155.

Pachler, N., Makoe, P., Burns, M., \& Blommaert, J. (2008). The things (we think) we (ought to) do: Ideological processes and practices in teaching. Teaching and Teacher Education, 24(2), 437-450.

Parrott, W. G. (2003). Positioning and the emotions. In R. Harrè \& F. Moghaddam (Eds.). The self and others: Positioning individuals and groups in personal, political, and cultural contexts (pp. 29-43). Westport, CT: Praeger.

Peshkin, A. (1998). In search of subjectivity: One's own. Educational Researcher, 17(7), $17-21$.

Peterson, D. S., Taylor, B. M., Burnham, B., \& Schock, R. (2009). Reflective coaching conversations: A missing piece. The Reading Teacher, 62(6), 500-509.

Pillow, W. (2003). Confession, catharsis, or cure? Rethinking the uses of reflexivity as methodological power in qualitative research. Qualitative Studies in Education, 16(2), 175-196.

Poglinco, S.M., Bach, A.J., Hovde, K., Rosenblum, S., Saunders, M., \& Supovitz, J.A. (2003). The heart of the matter: The coaching model in America's choice schools. Philadelphia: Consortium for Policy and Research in Education.

Powell, D. R., Steed, E. A., \& Diamond, K. E. (2009). Dimensions of literacy coaching with Head Start teachers. Topics in Early Childhood Education, 30(3), 148-161. 
Rainville, K. N. (2007). Situated identities, power, and positioning: Inside the practices ' of three literacy coaches in New Jersey (Doctoral dissertation, Columbia University).

Rainville, K. N. \& Jones, S. (2009). Situated identities: Power and positioning in the work of a literacy coach. The Reading Teacher, 61(6), 440-448.

Reutzel, D. R., \& Cooter, R. B. (1991). Organizing for effective instruction: The reading workshop. The Reading Teacher, 44(8), 548-554.

Richardson, V. \& Placier, P. (2001). Teacher change. In V. Richardson (ed.) Handbook of Research on Teaching (4th ed.), pp. 905-947. Washington, DC: American Educational Research Association.

Robb, L. (2000). Redefining staff development. Portsmouth, NH: Heinemann.

Rogoff, B. (1990). Apprenticeship in thinking: Cognitive development in social context. New York, NY: Oxford University Press.

Rosenstein, B., \& Sheva, B. (2002). Video use in social science research and program evaluation. International Journal of Qualitative Methods, 1(3), 22-43.

Rossman, G. B., \& Rallis, S. (2003). Learning in the field: An introduction to qualitative research. Thousand Oaks, CA: Sage Publications.

Roth, W. M., \& Radford, L. (2010). Re/thinking the zone of proximal development (symmetrically). Mind, culture, and activity, 17(4), 299-307.

Sachs, J. (1997). Renewing teacher professionalism through innovative links. Educational Action Research, 5(3), 449-462.

Sacks, H., Schegloff, E., \& Jefferson, G. (1974). A simplest systematic for the organization of turn taking in conversation. Language, 50, 696-735.

Schegloff, E. (1982). Discourse as an interactional achievement: Some use of" uh-huh" and other things that come between sentences. In D. Tannen (ed.) Analyzing Discourse: Text and Talk. Georgetown University Roundtable on Languages and Linguistics 1981 (pp. 71-93). Washington, DC: Georgetown University Press.

Schon, D. A. (1983). The reflective practitioner: How professionals think in action. New York: Basic Books.

Schutz, P. A., \& Zemblyas, M. (Eds.) (2009.) Advances in teacher emotion research: The impact on teachers' lives (pp. 3-11). New York: Springer. 
Scott, S. E., \& Cortina, K. S., \& Carlisle, J. F. (2012). Understanding coach-based professional development in Reading First: How do coaches spend their time and how do teachers perceive coaches' work? Literacy Research and Instruction, 51(1), 68-85.

Searle, J. (1992). The rediscovery of the mind. Cambridge: MIT Press.

Seloni, L. (2008). Reconceptualization of academic literacy socialization in an intercultural space: A micro-ethnographic inquiry of first year multilingual doctoral students in the U.S. Unpublished PhD Dissertation. State University of Ohio, USA.

Serafini, F. (2001). The reading workshop. Portsmouth, HN: Heinemann.

Shannon, P. (2001). iShop, you shop: Raising questions about reading commodities. Portsmouth, NH: Heinemann.

Shannon, P. (2004). The practice of democracy and Dewey's challenge. Language Arts, $82(1), 16-25$.

Sheehy, M. \&, Leander, K. M. (2004). Introduction. In K. M. Leander \& M. Sheehy (Eds.), Spatializing literacy research and practice (pp. 1-14). New York, NY: Peter Lang.

Shenton, A. K. (2004). Strategies for ensuring trustworthiness in qualitative research projects. Education for Information, 22(2), 63-75.

Showers, B., \& Joyce, B. (1996). The evolution of peer coaching. Educational Leadership, 53(6), 12-16.

Shrum, W., Duque, R., \& Brown, T. (2005). Digital video as research practice: Methodology for the millennium. Journal of Research Practice, 1(1), Article-M4.

Smagorinsky, P. (2011). Vygotsky and literacy research: A methodological framework. Rotterdam, The Netherlands: Sense Publishers.

Smith, A. T. (2007). The middle school literacy coach: Considering roles in context. National Reading Conference Yearbook, 56, 53-67.

Soja, E. (2004). Preface. In K. M. Leander \& M. Sheehy (Eds.), Spatializing literacy research and practice (pp. ix-xv). New York, NY: Peter Lang.

Solomon, R. C. (1993). The passions: Emotions and the meaning of life. Indianapolis, IN: Hackett Publishing Company. 
Spradley, J. P. (1980). Participant observation. New York: Holt Rinehart and Winston.

Steckel, B. (2009). Fulfilling the promise of literacy coaches in urban schools: What does it take to make an impact? The Reading Teacher, 63(1), 14-23.

Stephens, D., Donnelly, A., Morgan, D., DeFord, D., Hamil, E., Crowder, K., et al. (2011). The impact of literacy coaches on teachers' beliefs and practices. Journal of Literacy Research, 43(3), 215-249.

Stevens, E. Y., \& Hinchman, K. A. (2011, December). One beginning literacy specialist's positioning of her identity: A critical discourse analysis. Paper presented at the Literacy Research Association Conference, Jacksonville, FL.

Stover, K., Kissel, B., Haag, K., Shoniker, R. (2011). Differentiated coaching: Fostering reflection with teachers. The Reading Teacher, 64(7), 498-509.

Strauss, A., \& Corbin, J. (1990). Basics of qualitative research: Techniques and procedures for developing grounded theory. Thousand Oaks, CA: Sage.

Street, B. (1998). New literacies in theory and practice: What are the implications for language in education? Linguistics and Education, 10, 1-34.

Sturtevant, E. G. (2006). The literacy coach: A key to improving teaching and learning in secondary schools. Washington, D.C.: Alliance for Excellent Education.

Sturtevant, E. G., \& Linek, W. M. (2007). Secondary literacy coaching: A Macedonian perspective. Journal of Adolescent and Adult Literacy, 51(3), 240-250.

Sugrue, C. (2004). Rhetorics and realities of CPD across Europe: From cacophony towards coherence? In C. Day \& J. Sachs (Eds.) International handbook on the continuing professional development of teachers (pp. 67-93). Berkshire, England: Open University Press.

Sweeny, D. (2011). Student-centered coaching: A guide for K-8 coaches and principals. Thousand Oaks, CA: Corwin.

Tan, S. L., \& Moghaddam, F. M. (1999). Positioning in inter-group relations. In R. Harré \& L. van Langenhove (Eds.), Positioning theory: Moral contexts of intentional actions (pp. 178-194). Oxford: Blackwell.

Teemant, A. ,Wink, J., \& Tyra, S. (2010). Effects of coaching on teacher use of sociocultural instructional practices. Teaching and Teacher Education, 27(4), 683-693. 
Toll, C. A. (2005). The literacy coach's survival guide: Essential questions and practical answers. Newark, DE: International Reading Association.

Toll, C. A. (2006). The literacy coach's desk reference: Processes and perspectives for effective coaching. Urbana, IL: National Council of Teachers of English.

Toll, C. A. (2007). Lenses on literacy coaching: Conceptualizations, functions, and outcomes. Norwood, MA: Christopher-Gordon Publishers, Inc.

U.S. Department of Education. (2009). Race to the Top Program Executive Summary. Washington D.C.

Vanderburg, M. \& Stephens, D. (2010). The impact of literacy coaches: What teachers value and how teachers change. The Elementary School Journal, 111(1), 141-163.

Van Langenhove, L., \& Harré, R. (1999). Introducing positioning theory. In R. Harré \& L. van Langenhove (Eds.), Positioning theory: Moral contexts of intentional actions (pp. 14-31). Oxford: Blackwell.

Vogt, M. E. \& Shearer, B. A. (2007). Reading specialists and literacy coaches in the real world ( $2^{\text {nd }}$ edition). New York: Pearson.

Volosinov, V. (1973). Marxism and the philosophy of language. (I. Matejka \& I. R. Titunik, Trans.). New York: seminar (Original work published 1929).

Vygotsky, L. S. (1962). Thought and language. Cambridge, MA: MIT Press.

Vygotsky, L. S. (1978). Mind in society: The development of higher psychological processes. Cambridge, MA: Harvard University Press.

Walker-Dalhouse, D., Risko, V. J., Lathrop, K. \& Porter, S. (2010). Helping diverse struggling readers through reflective teaching and coaching. The Reading Teacher, 64(1), 70-72.

Walpole, S. \& Blamey, K.L. (2008). Elementary literacy coaches: The reality of dual roles. The Reading Teacher, 62(3), 222-231.

Walpole, S. \& McKenna, M. C. (2004). The literacy coach's handbook. New York: Guilford. Walpole, S., McKenna, M. C., Uribe-Zarain, X., \& Lamitina, D. (2010). The relationships between coaching and instruction in the primary grades: Evidence from high-poverty schools. Elementary School Journal, 111, 115-140.

Walpole, S., McKenna, M. C., \& Morrill, J. (2011). Building and rebuilding a statewide support system for literacy coaches. Reading and Writing Quarterly, 27(3), 261280. 
Walpole, S., McKenna, M. C., Uribe-Zarain, X., \& Lamitina, D. (2010). The relationships between coaching and instruction in the primary grades: Evidence from high-poverty schools. The Elementary School Journal, 111(1), 115-140.

Watson, C. (2007). Small stories, positioning analysis, and the doing of professional identities in learning to teach. Narrative Inquiry, 17(2), 371-389.

Webster, S. R. (2009). How evidence-based teaching practices are challenged by a Deweyan approach to education. Asia-Pacific Journal of Teacher Education, 27(2), 215-227.

Webster-Wright, A. (2009). Reframing professional development through understanding authentic professional learning. Review of educational research, 79(2), 702-739.

Weedon, C. (1987). Feminist practice \& poststructuralist theory. Oxford: Blackwell. West, L., \& Staub, F. C. (2003). Content-focuses coaching: Transforming mathematics lessons. Portsmouth, NH: Heinemann.

Whitmore, K. F., Martens, P., Goodman, Y., \& Owocki, G. (2005). Remembering critical lessons in early literacy research: A transactional perspective. Language Arts, 82(5), 296-307.

Wodak, L.A., \& Kroger, R. (2000). Doing discourse analysis. Methods for studying action in talk and text. Thousand Oaks, CA: Sage Publications.

Wood, D., Bruner, J. S., \& Ross, G. (1976). The role of tutoring in problem solving. Journal of Child Psychology and Psychiatry, 17(2), 89-100.

Yngve, V. (1970). On getting a word in edgewise. In Papers from the sixth regional meeting of the Chicago Linguistic Society (pp. 567-77), Chicago, IL: Chicago Linguistic Society.

Zembylas, M. (2003). Interrogating "teacher identity": Emotion, resistance, and selfformation. Educational Theory. 53(1), 107-127.

Zembylas, M. (2005a). Discursive practices, genealogies, and emotional rules: A poststructuralist view on emotion and identity in teaching. Teaching and Teacher Education, 21, 935-948.

Zembylas, M. (2005b). Teaching with emotion: A postmodern enactment. Greenwich: CT: Information Age Publishing. 
APPENDIX A

\section{RESEARCH JOURNAL ENTRY}


February 22, 2013

I am feeling really overwhelmed (what else is new) and uncomfortable about the microanalysis of the first video segment of Tiffany and Sarah "co"planning. The problem is that it is a very asymmetrical interaction with Sarah taking the lead almost entirely and disregarding Tiffany's comments when she does make them. However, this positioning doesn't fit the story that either one of the participants tell themselves about their relationship. I don't want Sarah to think that I am judging her negatively, but I suppose that maybe I am. I don't think she wants to look at her power honestly. I want to paint them fairly by acknowledging the positive aspects of their relationship, but I will not ignore positionings because they may contradict the participants' understandings. I think that the challenge is to honor their viewpoints, respect the stories they tell about themselves, but also acknowledge the subtleties of those stories. It is really messy territory, and I'm feeling trepidations about revealing the story that I'm seeing unfolding and about the possibility of my misrepresenting the participants due to my own agendas. How can I make all the relevant agendas clear in my analysis and in the reporting of my findings? 
APPENDIX B

TRANSCRIPT CONVENTIONS 


\section{Transcription Key:}

|= one second pause

$\downarrow \uparrow=$ lowering or rising intonation

$\underline{\text { Underline }}=$ emphasis

$:=$ extended vowel

*phrase* = change in pitch or intonation, described in contextual cues column

[ ] Overlapping turns of talk 
APPENDIX C

FULL TRANSCRIPT OF SPECIAL EDUCATION MEETING 


\begin{tabular}{|c|c|c|}
\hline \multicolumn{3}{|c|}{ Sub-event 1: Interaction with Tiffany and Danielle about Modeling in Reading Conferences } \\
\hline Line & Speaker & Transcription \\
\hline \multicolumn{3}{|c|}{ Interactional Unit (IU) 1} \\
\hline 1 & Sarah $\rightarrow$ Group & so what's your thinking about that video $\uparrow$ \\
\hline $\begin{array}{l}2 \\
3 \\
4\end{array}$ & Tiffany $\rightarrow$ Sarah & $\begin{array}{l}\text { I like how she carried } \\
\text { like | a book with her } \uparrow \\
\text { to show her } \mid \text { own examples } \uparrow\end{array}$ \\
\hline 5 & Sarah $\rightarrow$ Tiffany & hm.mm \\
\hline $\begin{array}{l}6 \\
7 \\
8\end{array}$ & Tiffany $\rightarrow$ Sarah & $\begin{array}{l}\text { and to show how she would do it } \\
\text { like for her topic words } \\
\text { which is | you know | exactly what he was doing with his }\end{array}$ \\
\hline 9 & Sarah $\rightarrow$ Tiffany & hm.mm \\
\hline 10 & Tiffany $\rightarrow$ Sarah & so | I thought that was good \\
\hline \multicolumn{3}{|l|}{ IU2 } \\
\hline $\begin{array}{l}11 \\
12 \\
13 \\
14 \\
15 \\
16 \\
17 \\
18 \\
19 \\
20 \\
21 \\
22 \\
23\end{array}$ & Sarah $\rightarrow$ Tiffany & $\begin{array}{l}\text { and I think that's something that you can do } \\
\text { when you're doing a read aloud } \uparrow \text { with the kids } \\
\text { if you have } \\
\text { even like in science or social studies } \\
\text { you have a text that you've read aloud | } \\
\text { um | then that's your thinking } \uparrow \\
\text { and so if you can model that } \\
\text { and actually have that as part of your read aloud } \\
\text { you do a think aloud as you go along } \\
\text { you can model how you stop } \\
\text { and ask those questions of yourself } \\
\text { or you make that prediction on a sticky note } \\
\text { and you know then you can bring it }\end{array}$ \\
\hline \multicolumn{3}{|l|}{ IU3 } \\
\hline $\begin{array}{l}24 \\
25 \\
26 \\
27\end{array}$ & Danielle $\rightarrow$ Sarah & $\begin{array}{l}\text { you know } \\
\text { we do that in like our mini lessons } \\
\text { but it's like I don't ever think to do that in my conferring } \\
\text { you know }\end{array}$ \\
\hline 28 & Sarah $\rightarrow$ Danielle & hm.mm \\
\hline $\begin{array}{l}29 \\
30 \\
31 \\
32\end{array}$ & Danielle $\rightarrow$ Sarah & $\begin{array}{l}\text { to bring my own mentor text with me } \\
\text { and sayl you know } \\
\text { this is what | } \\
\text { here's what I did }\end{array}$ \\
\hline 33 & Sarah $\rightarrow$ Danielle & hm.mm \\
\hline $\begin{array}{l}34 \\
35\end{array}$ & Danielle $\rightarrow$ Sarah & $\begin{array}{l}\text { you can do that in } \\
\text { you know }\end{array}$ \\
\hline 36 & Sarah $\rightarrow$ Danielle & yeah \\
\hline $\begin{array}{l}37 \\
38\end{array}$ & Danielle $\rightarrow$ Tiffany & $\begin{array}{l}\text { yeah } \\
\text { I like that part of it too }\end{array}$ \\
\hline \multicolumn{3}{|l|}{ IU4 } \\
\hline $\begin{array}{l}39 \\
40 \\
41 \\
42 \\
43 \\
44\end{array}$ & Sarah $\rightarrow$ Danielle & $\begin{array}{l}\text { and sometimes } \\
\text { that can be your carry over } \\
\text { you know } \\
\text { when you think about } \\
\text { what is your focus for the kids right now } \\
\text { during your mini lesson }\end{array}$ \\
\hline $\begin{array}{l}45 \\
46\end{array}$ & Sarah $\rightarrow$ Group & $\begin{array}{l}\text { you know } \\
\text { during the read aloud }\end{array}$ \\
\hline 47 & Sarah $\rightarrow$ Danielle & um $\mid$ and then being able to take it to the conferring part \\
\hline
\end{tabular}




\begin{tabular}{|l|l|l|}
\hline 48 & & you know \\
49 & & because that's something then \\
\hline 50 & Sarah $\rightarrow$ Group & kind of like in writers workshop \\
51 & & we're giving them strategies to write with \\
52 & & in reading we give them these strategies \\
53 & & they might not use all of them | um always \\
54 & & but if you're focusing in on one \\
55 & & you would see a little bit of evidence \\
56 & & of them trying it \\
57 & & you know \\
58 & & in those stories \\
59 & & so if questioning was the focus that you had \\
60 & & you would hope that you would see them \\
61 & & doing some of that \\
\hline 62 & Sarah $\rightarrow$ Danielle & and then yeah \\
63 & & you could bring your own \\
\hline
\end{tabular}

\begin{tabular}{|c|c|c|}
\hline \multicolumn{3}{|c|}{$\begin{array}{l}\text { Sub-event 2: Interaction with Danielle about Language Use in Conferences and Conferencing in } \\
\text { Content Areas }\end{array}$} \\
\hline Line & Speaker & Transcription \\
\hline \multicolumn{3}{|c|}{ Interactional Unit (IU) 1} \\
\hline $\begin{array}{l}1 \\
2 \\
3 \\
4 \\
5 \\
6 \\
7 \\
8\end{array}$ & Danielle $\rightarrow$ Sarah & $\begin{array}{l}\text { I wrote down } \\
\text { just the wording that she used was } \\
\text { "is that something you might want to do } \uparrow " \\
\text { and [laugh] with junior high } \\
\text { that's not really something you could ask them } \\
\text { because they're going to be like } \\
\text { no:o } \| \text { I don't want to do that } \\
\text { but you know }\end{array}$ \\
\hline $\begin{array}{l}9 \\
10 \\
11\end{array}$ & Sarah $\rightarrow$ Danielle & $\begin{array}{l}\text { can you think about what we talked } \\
\text { in the architecture of a conference though } \\
\text { what might you say | differently } \uparrow\end{array}$ \\
\hline 12 & Danielle $\rightarrow$ Sarah & can I give you a tip $\uparrow$ \\
\hline $\begin{array}{l}13 \\
14 \\
15 \\
16 \\
17 \\
18 \\
19 \\
20\end{array}$ & Sarah $\rightarrow$ Danielle & $\begin{array}{l}\text { yes } \mid \text { or } \\
\text { so as readers we know that one thing we can do is } \\
\text { so as you read today } \\
\text { continue asking those questions } \\
\text { but if they don't get answered } \\
\text { take it with you to the next } \\
\text { you know } \\
\text { text or the next story }\end{array}$ \\
\hline \multicolumn{3}{|l|}{ IU2 } \\
\hline $\begin{array}{l}21 \\
22 \\
23 \\
24 \\
25 \\
26 \\
27 \\
28\end{array}$ & Danielle $\rightarrow$ Sarah & $\begin{array}{l}\text { and she was complimenting him throughout } \\
\text { it wasn't | you know | just at the beginning } \\
\text { she kept on going back } \\
\text { and she said } \\
\text { you know } \\
\text { carry that good thinking on your next book } \\
\text { and also those questions that you don't have answered } \\
\text { carry it on to your book }\end{array}$ \\
\hline 29 & Sarah $\rightarrow$ Danielle & hm.mm \\
\hline
\end{tabular}




\begin{tabular}{|c|c|c|}
\hline IU3 & & \\
\hline $\begin{array}{l}30 \\
31 \\
32\end{array}$ & Danielle $\rightarrow$ Sarah & $\begin{array}{l}\text { and I think that is more } \\
\text { I could use this more in my science } \\
\text { you know }\end{array}$ \\
\hline 33 & Sarah $\rightarrow$ Danielle & hm.mm \\
\hline $\begin{array}{l}34 \\
35\end{array}$ & Danielle $\rightarrow$ Sarah & $\begin{array}{l}\text { science and social studies } \\
\text { that type of a conference }\end{array}$ \\
\hline $\begin{array}{l}36 \\
37 \\
38\end{array}$ & Sarah $\rightarrow$ Danielle & $\begin{array}{l}\text { hm.mm } \\
\text { but you still saw } \\
\text { like she did the research }\end{array}$ \\
\hline 39 & Danielle $\rightarrow$ Sarah & yeah \\
\hline $\begin{array}{l}40 \\
41 \\
42 \\
43 \\
44 \\
45 \\
46 \\
47 \\
48 \\
49 \\
50 \\
51 \\
52 \\
53 \\
54 \\
55 \\
56 \\
57 \\
58\end{array}$ & Sarah $\rightarrow$ Group & $\begin{array}{l}\text { you know } \\
\text { she asked him share um | } \\
\text { you know } \\
\text { talk to me about your post its } \\
\text { you know } \\
\text { there was no } \mid \text { judgment } \\
\text { there was no like direct } \\
\text { it was just } \\
\text { talk to me about what you've done so far } \\
\text { so she's doing a little research } \\
\text { and then she did } \\
\text { I mean } \\
\text { she complimented him } \\
\text { and then she showed examples of how she did it too } \\
\text { and then gave him a suggestion of } \\
\text { you could put them on the front of your next book } \\
\text { to remind you } \\
\text { you have that question } \\
\text { so she really covered } \uparrow\end{array}$ \\
\hline 59 & Danielle $\rightarrow$ Sarah & hm.mm \\
\hline $\begin{array}{l}60 \\
61 \\
62 \\
63 \\
64 \\
65 \\
66 \\
67 \\
68 \\
69 \\
70 \\
71 \\
72 \\
73 \\
74 \\
75 \\
76 \\
77 \\
78 \\
79 \\
80 \\
81 \\
82\end{array}$ & Sarah $\rightarrow$ Group & $\begin{array}{l}\text { you know } \\
\text { everything in there } \\
\text { and I think } \\
\text { one of the things | um } \\
\text { when we talk about that architecture | is } \\
\text { you know } \\
\text { we talk about } \\
\text { having them practice it } \\
\text { right then and there } \downarrow \\
\text { and | |you know } \\
\text { the type of conference that you just sa:w } \\
\text { is not really } \\
\text { I mean } \\
\text { she did not have him practice writing a question } \\
\text { but she could see he did it } \uparrow \\
\text { so she physically put that post it } \\
\text { like on the next book } \\
\text { to show him what to do } \\
\text { so | um | you know } \\
\text { not always | } \\
\text { is there something you can physically have them do right then } \uparrow \\
\text { but | giving them that | um | tip or that link to take back with them } \uparrow \\
\text { and then being able to check back in with them }\end{array}$ \\
\hline
\end{tabular}


yeah

\begin{tabular}{|c|c|c|}
\hline \multicolumn{3}{|c|}{ Sub-event 3: Nina's small story about conferring as accountability } \\
\hline Line & Speaker & $\begin{array}{ll}\text { Transcription } \\
\end{array}$ \\
\hline \multicolumn{3}{|c|}{ Interactional Unit (IU) 1} \\
\hline 1 & Sarah $\rightarrow$ Group & anything else you noticed in this conference $\uparrow \mid$ that \\
\hline $\begin{array}{l}2 \\
3 \\
4 \\
5 \\
6\end{array}$ & Nina $\rightarrow$ Sarah & $\begin{array}{l}\text { I liked that it wasn't } \\
\text { a five minute conference } \downarrow \\
\text { it was } \\
\text { you know } \\
2 \text { or } 3 \text { minutes }\end{array}$ \\
\hline 7 & Sarah $\rightarrow$ Nina & hm.mm \\
\hline $\begin{array}{l}8 \\
9 \\
10\end{array}$ & Nina $\rightarrow$ Sarah & $\begin{array}{l}\text { And to the point } \\
\text { And it didn't just go on and on and on } \\
\text { I like that } \downarrow\end{array}$ \\
\hline \multicolumn{3}{|r|}{ 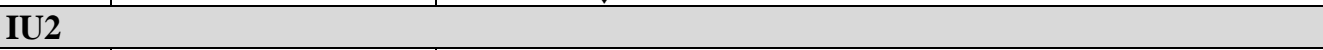 } \\
\hline Line & Speaker & Transcription \\
\hline $\begin{array}{l}11 \\
12\end{array}$ & Nina $\rightarrow$ Sarah & $\begin{array}{l}\text { "cause I have kind of found that } \\
\text { we have been conferring in our language arts class } \uparrow\end{array}$ \\
\hline 13 & Sarah $\rightarrow$ Nina & hm.mm \\
\hline $\begin{array}{l}14 \\
15\end{array}$ & Nina $\rightarrow$ Sarah & $\begin{array}{l}\text { and | Luke and I have each taken half of the class } \\
\text { and every day at the beginning of the hour }\end{array}$ \\
\hline 16 & Sarah $\rightarrow$ Nina & hm.mm \\
\hline $\begin{array}{l}17 \\
18 \\
19\end{array}$ & Nina $\rightarrow$ Sarah & $\begin{array}{l}\text { w:e confer with each student } \\
\text { about what they're reading } \\
\text { their independent reading book }\end{array}$ \\
\hline 20 & Sarah $\rightarrow$ Nina & hm.mm \\
\hline \multicolumn{3}{|l|}{ IU3 } \\
\hline $\begin{array}{l}21 \\
22\end{array}$ & Nina $\rightarrow$ Sarah & $\begin{array}{l}\text { and it kinda makes them accountable } \downarrow \\
\text { s:o they're not sitting there fake reading } \mid \text { or }\end{array}$ \\
\hline 23 & Sarah $\rightarrow$ Nina & hm.mm \\
\hline $\begin{array}{l}24 \\
25 \\
26 \\
27 \\
28 \\
29 \\
30 \\
31 \\
32\end{array}$ & Nina $\rightarrow$ Sarah & $\begin{array}{l}\text { you know } \\
\text { and we know } \\
\text { we can tell if they're comprehending } \\
\text { like I've done } \\
\text { I've changed, } \\
\text { I had kids } \\
\text { probably } 5 \text { or } 6 \text { ki:ds change books } \downarrow \\
\text { because they're not comprehending it } \\
\text { and I can tell }\end{array}$ \\
\hline 33 & Sarah $\rightarrow$ Nina & hm.mm \\
\hline $\begin{array}{l}34 \\
35 \\
36 \\
37\end{array}$ & Nina $\rightarrow$ Sarah & $\begin{array}{l}\text { you know } \\
\text { I'm like hey you know what } \uparrow \\
\text { this is probably a little bit too hard for you } \\
\text { let's try to find another book }\end{array}$ \\
\hline 38 & Sarah $\rightarrow$ Nina & right \\
\hline \multicolumn{3}{|l|}{ IU4 } \\
\hline $\begin{array}{l}39 \\
40 \\
41\end{array}$ & Nina $\rightarrow$ Group & $\begin{array}{l}\text { but } \mid \text { you know } \\
\text { we're trying to have our conferences between } 2 \text { and } 3 \text { minutes } \\
\text { and that's all }\end{array}$ \\
\hline 42 & Sarah $\rightarrow$ Nina & hm.mm \\
\hline 43 & Nina $\rightarrow$ Sarah & I mean \\
\hline
\end{tabular}




\begin{tabular}{|c|c|c|}
\hline $\begin{array}{l}44 \\
45\end{array}$ & & $\begin{array}{l}\text { you have to so you can } \\
\text { you know }\end{array}$ \\
\hline 46 & Sarah $\rightarrow$ Nina & right \\
\hline $\begin{array}{l}47 \\
48\end{array}$ & Nina $\rightarrow$ Sarah & $\begin{array}{l}\text { try to touch base with every kid } \downarrow \\
\text { but }\end{array}$ \\
\hline 49 & Sarah $\rightarrow$ Nina & hm.mm \\
\hline \multicolumn{3}{|c|}{ IU5 } \\
\hline $\begin{array}{l}50 \\
51 \\
52\end{array}$ & Nina $\rightarrow$ Sarah & $\begin{array}{l}\text { I like that's it's not } \\
\text { you know } \\
\text { it's a touching base with them } \downarrow\end{array}$ \\
\hline 53 & Sarah $\rightarrow$ Nina & $\mathrm{hm} . \mathrm{mm}$ \\
\hline $\begin{array}{l}54 \\
55\end{array}$ & Nina $\rightarrow$ Sarah & $\begin{array}{l}\text { And making sure they're understanding it } \\
\text { And stuff like that }\end{array}$ \\
\hline 56 & Sarah $\rightarrow$ Nina & yeah \\
\hline $\begin{array}{l}57 \\
58 \\
\end{array}$ & Nina $\rightarrow$ Sarah & $\begin{array}{l}\text { because that's kind of what we're doing } \\
\text { in language arts class }\end{array}$ \\
\hline \multicolumn{3}{|c|}{ IU6 } \\
\hline $\begin{array}{l}59 \\
60 \\
61 \\
62 \\
63 \\
64 \\
65 \\
66 \\
67 \\
68 \\
69 \\
70 \\
71 \\
72 \\
73 \\
74 \\
75 \\
76 \\
77 \\
78 \\
79 \\
80 \\
81 \\
82\end{array}$ & Sarah $\rightarrow$ Nina & $\begin{array}{l}\text { hm.mm } \\
\text { and there are } \\
\text { I mean } \\
\text { there is that touch base type of conference } \\
\text { and then } \\
\text { you know } \\
\text { there's like this type of conference } \\
\text { she is focusing on the strategy of questioning } \\
\text { and so she's giving him that strategy to continue to use } \downarrow \\
\text { and I think } \\
\text { even with their independent books } \\
\text { you can talk about them } \\
\text { you know } \\
\text { have you used some strata.... } \\
\text { you know } \\
\text { strategies in your reading } \uparrow \\
\text { you know } \\
\text { what did you tr:y } \\
\text { to help you understand the story better } \uparrow \\
\text { you know } \\
\text { to see if they've even tri:ed } \\
\text { sometimes they just give up } \\
\text { but have you tried some things } \\
\text { that would help you understand the story better } \uparrow\end{array}$ \\
\hline \multicolumn{3}{|c|}{ IU7 } \\
\hline $\begin{array}{l}83 \\
84 \\
85 \\
86 \\
87 \\
88\end{array}$ & Nina $\rightarrow$ Sarah & $\begin{array}{l}\text { yeah } \\
\text { and we do that at the very end | at the end we } \\
\text { you know } \\
\text { okay do you have a prediction } \uparrow \\
\text { you know } \\
\text { tell us | tell me about a character or something }\end{array}$ \\
\hline $\begin{array}{l}89 \\
90\end{array}$ & Sarah $\rightarrow$ Nina & $\begin{array}{l}\text { hm.mm } \\
\text { sure }\end{array}$ \\
\hline $\begin{array}{l}91 \\
92\end{array}$ & Nina $\rightarrow$ Sarah & $\begin{array}{l}\text { we try to do that at the end of each conference } \\
\text { so }\end{array}$ \\
\hline
\end{tabular}




\begin{tabular}{|l|l|l|}
\hline \multicolumn{2}{|c|}{ Sub-event 4: Talk Time during Conferences } \\
\hline Line & \multicolumn{1}{|c|}{ Speaker } & \multicolumn{1}{|c|}{ Transcription } \\
\hline Interactional Unit (IU) 1 & \multicolumn{2}{|l|}{} \\
\hline 1 & Sarah $\rightarrow$ Group & one of the things that \\
2 & & what did you notice about the |uh| \\
3 & & amount of time the teacher spoke \\
4 & & and the amount of time that the student spoke \\
5 & & during the conference $\uparrow$ \\
\hline 6 & Tiffany $\rightarrow$ Sarah & the teacher talked more than the student \\
\hline 7 & Sarah $\rightarrow$ Group & yeah \\
8 & & and that was one thing I noticed \\
9 & & I mean I've watched it a couple of times \\
10 & & um ||personally my feeling is \\
11 & & she talked too much \\
12 & & that it would've been \\
13 & & you know \\
14 & & it would've been nice \\
15 & to hear from the student \\
16 & & just a little bit more \\
17 & & I know that she was | um instructing a little bit there \\
18 & & but I think \\
19 & & it would've been nice \\
20 & & to hear him and some of his thinking about \\
21 & & you know \\
22 & & is there a question $\uparrow$ \\
23 & & instead of saying \\
24 & & you know \\
25 & & it looks like you've read so much of this story \\
26 & & and you haven't had your question answered \\
27 & & maybe even posing another question to him \\
28 & & like is there a question \\
29 & towards the end of your book \\
30 & that hasn't been answered yet $\uparrow$ \\
31 & & and have him find that question \\
33 & and then use that question \\
34 & & as the one that he takes with him \\
35 & & but I noticed that too \\
36 & she talked a little bit more \\
\hline
\end{tabular}

\begin{tabular}{|l|l|l|}
\hline \multicolumn{2}{|c|}{ Sub-event 5: Discussion about Noticing and Naming } \\
\hline Line & \multicolumn{1}{|c|}{ Speaker } & \multicolumn{1}{c|}{ Transcription } \\
\hline IU1 & \multicolumn{2}{|c|}{} \\
\hline 1 & Amy $\rightarrow$ Sarah & it also seemed like too \\
2 & & like I remember the one \\
3 & & where he put something down about how alligators swam really fast \\
4 & & a:nd she was like oh I noticed you marked this \\
5 & & and I know sometimes I'm guilty too \\
6 & & of talking too much to the kid \\
7 & & because I'm like \\
8 & & are they getting it $\uparrow$ are they getting it $\uparrow$ \\
9 & & um | instead of maybe saying \\
10 & & oh you marked this because you found this really interesting \\
\hline
\end{tabular}




\begin{tabular}{|c|c|c|}
\hline $\begin{array}{l}11 \\
12 \\
13 \\
14 \\
\end{array}$ & & $\begin{array}{l}\text { she kind of told him why he marked it } \\
\text { instead of saying } \\
\text { okay so why did you mark this } \uparrow \\
\text { a:nd [you know }\end{array}$ \\
\hline 15 & Sarah $\rightarrow$ Amy & kind of helping him \\
\hline $\begin{array}{l}16 \\
17 \\
18 \\
19 \\
20\end{array}$ & Amy $\rightarrow$ Sarah & $\begin{array}{l}\text { instead of saying ] } \\
\text { I thought that was really interesting } \\
\text { she kind of almost seemed like } \\
\text { told him why he marked things } \uparrow\end{array}$ \\
\hline \multicolumn{3}{|c|}{ IU2 } \\
\hline $\begin{array}{l}21 \\
22 \\
23 \\
24 \\
25 \\
26 \\
27 \\
28 \\
29 \\
30 \\
31 \\
32 \\
33 \\
34 \\
35 \\
36 \\
37 \\
38 \\
39 \\
40 \\
41 \\
42 \\
43 \\
44 \\
45 \\
46 \\
47 \\
48 \\
49 \\
50\end{array}$ & Sarah $\rightarrow$ Amy & $\begin{array}{l}\text { hm.mm } \\
\text { and sometimes } \\
\text { I and this goes back to our } \\
\text { the book we're reading } \\
\text { and the chapter that we just read } \\
\text { was on noticing and naming things } \\
\text { and I think } \\
\text { for younger kids sometimes } \\
\text { and older kids too } \\
\text { that sometimes } \\
\text { and I had actually wrote that down } \\
\text { um / written that down here } \\
\text { that she named what was done for him } \\
\text { like she names that the sticky note was a 'wow' sticky note } \\
\text { and she named it } \\
\text { and I'm wondering } \\
\text { if she named it for him } \\
\text { because maybe he didn't know why } \uparrow \\
\text { he had marked it } \\
\text { and she's trying to get him to realize } \\
\text { that here are different reasons why we might put a post it note in } \\
\text { that it's a 'wow' } \\
\text { or it's a } \\
\text { you know } \\
\text { I compared something } \\
\text { you know } \\
\text { I thought about something else } \\
\text { and I wrote down because it was interesting and } \\
\text { I mean I don't know } \\
\text { that was just my thought }\end{array}$ \\
\hline \multicolumn{3}{|c|}{ IU3 } \\
\hline 51 & Amy $\rightarrow$ Sarah & [It could be \\
\hline $\begin{array}{l}52 \\
53 \\
54 \\
55 \\
56\end{array}$ & Danielle $\rightarrow$ Sarah & $\begin{array}{l}\text { I've done that a lot] } \\
\text { with inferring } \\
\text { like kids are inferring } \\
\text { but they don't really know what they're } \\
\text { you know }\end{array}$ \\
\hline 57 & Sarah $\rightarrow$ Danielle & hm.mm \\
\hline 58 & Danielle $\rightarrow$ Sarah & they don't know that they're doing it \\
\hline 59 & Sarah $\rightarrow$ Danielle & yeah \\
\hline $\begin{array}{l}60 \\
61 \\
62\end{array}$ & Danielle $\rightarrow$ Sarah & $\begin{array}{l}\text { and to tell them } \\
\text { well you just did it } \\
\text { you know }\end{array}$ \\
\hline
\end{tabular}




\begin{tabular}{|c|c|c|}
\hline 63 & & [that was inference \\
\hline $\begin{array}{l}64 \\
65\end{array}$ & Amy $\rightarrow$ Danielle & $\begin{array}{l}\text { I had the same discussion] } \\
\text { [with one of my kids }\end{array}$ \\
\hline $\begin{array}{l}66 \\
67 \\
68 \\
69 \\
70 \\
\end{array}$ & Sarah $\rightarrow$ Danielle & $\begin{array}{l}\text { yeah] } \\
\text { and that's a hu:ge strategy } \\
\text { I mean } \\
\text { that's a [huge skill } \\
\text { but it's hard }\end{array}$ \\
\hline 71 & Danielle $\rightarrow$ Sarah & That's the hardest] thing right now \\
\hline $\begin{array}{l}72 \\
73 \\
74\end{array}$ & $\begin{array}{l}\text { Sarah } \rightarrow \text { Danielle } \\
\text { Sarah } \rightarrow \text { Group }\end{array}$ & $\begin{array}{l}\text { right } \\
\text { and itr them to recognize that that's what they're doing } \\
\text { to make them aware that they can make inferences }\end{array}$ \\
\hline 75 & Danielle $\rightarrow$ Sarah & yeah \\
\hline 76 & Sarah $\rightarrow$ Group & I would say that that's really important \\
\hline \multicolumn{3}{|l|}{ IU4 } \\
\hline $\begin{array}{l}77 \\
78 \\
79\end{array}$ & Amy $\rightarrow$ Sarah & $\begin{array}{l}\text { especially cause when you infer } \\
\text { it's more of that abstract thought too }\end{array}$ \\
\hline 80 & Sarah $\rightarrow$ Amy & hm.mm \\
\hline $\begin{array}{l}81 \\
82 \\
83\end{array}$ & Amy $\rightarrow$ Sarah & $\begin{array}{l}\text { and a lot of the students that are in the CIM groups } \\
\text { not necessarily have that ability } \uparrow \\
\text { or be super strong in that ability }\end{array}$ \\
\hline 84 & Sarah $\rightarrow$ Amy & hm.mm \\
\hline 85 & Amy $\rightarrow$ Sarah & to think abstractly yet \\
\hline \multicolumn{3}{|c|}{ IU3b } \\
\hline $\begin{array}{l}86 \\
87 \\
88 \\
89 \\
90 \\
91 \\
92 \\
93\end{array}$ & $\begin{array}{l}\text { Sarah } \rightarrow \text { Amy } \\
\text { Sarah } \rightarrow \text { Danielle }\end{array}$ & $\begin{array}{l}\text { yeah } \\
\text { and I'm just wondering } \\
\text { when you do that } \uparrow \\
\text { I'm just asking a question } \downarrow \\
\text { but } \mid \text { um do you restate what they just told you } \uparrow \\
\text { so they can hear it back again } \uparrow \\
\text { you know } \downarrow \\
\text { so that it }\end{array}$ \\
\hline $\begin{array}{l}94 \\
95 \\
96\end{array}$ & Danielle $\rightarrow$ Sarah & $\begin{array}{l}\text { at times } \\
\text { probably not every time } \\
\text { but }\end{array}$ \\
\hline $\begin{array}{l}97 \\
98 \\
99 \\
100\end{array}$ & Sarah $\rightarrow$ Danielle & $\begin{array}{l}\text { I'm just wondering } \\
\text { if that might be a good thing to do for them } \\
\text { so that } \\
\text { [when you said this }\end{array}$ \\
\hline 101 & Danielle $\rightarrow$ Sarah & so in their own words] \\
\hline $\begin{array}{l}102 \\
103 \\
104 \\
105 \\
106 \\
107 \\
108 \\
109\end{array}$ & Sarah $\rightarrow$ Danielle & $\begin{array}{l}\text { that was inference } \\
\text { yeah } \\
\text { so they can recognize it again } \\
\text { I mean if they do it again } \\
\text { they can hear their own words } \\
\text { and you've } \\
\text { you know } \\
\text { [you've already repeated it to them }\end{array}$ \\
\hline $\begin{array}{l}110 \\
111\end{array}$ & Danielle $\rightarrow$ Sarah & $\begin{array}{l}\text { yeah } \\
\text { that's a good idea] }\end{array}$ \\
\hline $\begin{array}{l}112 \\
113 \\
\end{array}$ & Sarah $\rightarrow$ Danielle & $\begin{array}{l}\text { so yeah } \\
\text { because }\end{array}$ \\
\hline
\end{tabular}




\begin{tabular}{|l|l|l|}
\hline 114 & & I don't know \\
115 & & but I think \\
116 & & sometimes they probably already forgot what they said \\
\hline 117 & Danielle $\rightarrow$ Sarah & yeah \\
118 & & so instead of saying that was an inferences \\
119 & & saying you said da,da,da,da \\
\hline 120 & Sarah $\rightarrow$ Danielle & yeah yeah \\
121 & & just kind of restating what they said \\
122 & & allright \\
\hline
\end{tabular}

\begin{tabular}{|c|c|c|}
\hline \multicolumn{3}{|r|}{ Sub-event 5: Discussion about Noticing and Naming } \\
\hline Line & Speaker & Transcription \\
\hline \multicolumn{3}{|c|}{ IU1: Request to see Sarah do a conference } \\
\hline 1 & Sarah $\rightarrow$ Group & so we'll watch another one $\uparrow$ \\
\hline 2 & Danielle $\rightarrow$ Sarah & I'd love to watch you \\
\hline 3 & Sarah $\rightarrow$ Group & you want to watch m:e $\uparrow$ \\
\hline 4 & Group $\rightarrow$ Sarah & ye:ah \\
\hline 5 & Sarah $\rightarrow$ Group & re:ally^ \\
\hline \multicolumn{3}{|c|}{ IU2: Request to see a local teacher do a conference or to see a produced content area conference } \\
\hline $\begin{array}{l}6 \\
7 \\
8 \\
9\end{array}$ & Amy $\rightarrow$ Sarah & $\begin{array}{l}\text { in Heidi's class } \\
\text { did Heidi do the conference } \uparrow \\
\text { or did you do the conferencing } \uparrow \\
\text { you said you videotaped it }\end{array}$ \\
\hline $\begin{array}{l}10 \\
11 \\
12 \\
13\end{array}$ & Sarah $\rightarrow$ Group & $\begin{array}{l}\text { um | this particular one } \\
\text { um| I did } \\
\text { um | Heidi did math } \\
\text { but I did a science one }\end{array}$ \\
\hline 14 & Amy $\rightarrow$ Sarah & so did you videotape Heidi doing math $\uparrow$ \\
\hline $\begin{array}{l}15 \\
16 \\
\end{array}$ & Sarah $\rightarrow$ Amy & $\begin{array}{l}\text { I did } \\
\text { but I didn't ask her if I could share it with you }\end{array}$ \\
\hline 17 & Amy $\rightarrow$ Sarah & okay \\
\hline 18 & Sarah $\rightarrow$ Amy & so I'd rather [ask her first but \\
\hline $\begin{array}{l}19 \\
20 \\
21 \\
22 \\
\end{array}$ & Amy $\rightarrow$ Sarah & $\begin{array}{l}\text { well if you'd ask her later } \uparrow] \\
\text { because I } \\
\text { when we watch all these videos } \\
\text { I'm like not seeing math ones }\end{array}$ \\
\hline 23 & Sarah $\rightarrow$ Amy & no \\
\hline 24 & Amy $\rightarrow$ Sarah & I know that this system's set up for reading \\
\hline $\begin{array}{l}25 \\
26 \\
27 \\
\end{array}$ & Sarah $\rightarrow$ Amy & $\begin{array}{l}\text { no } \\
\text { I'm sure she would be fine } \\
\text { but I would rather ask her first }\end{array}$ \\
\hline $\begin{array}{l}28 \\
29 \\
30 \\
31 \\
32 \\
33 \\
34 \\
35 \\
36 \\
37 \\
38\end{array}$ & Amy $\rightarrow$ Sarah & $\begin{array}{l}\text { yeah } \\
\text { I just didn't know } \\
\text { like if they do } \\
\text { I know this whole thing is about } \\
\text { like the reading conferring } \\
\text { that's why they put the videos out | the company } \\
\text { but I didn't know } \\
\text { if there was a lot out there } \\
\text { where you could watch } \\
\text { people do |conferring in math } \\
\text { and an actually good | source }\end{array}$ \\
\hline
\end{tabular}




\begin{tabular}{|l|l|l|}
\hline 39 & & not like a you tube video \\
40 & & that you watch someone doing it or something \\
\hline 41 & Sarah $\rightarrow$ Amy & right \\
42 & & there are \\
43 & & um and we're trying to get more videos \\
\hline 44 & Amy $\rightarrow$ Sarah & or science or social studies \\
\hline $\begin{array}{l}\text { Note. As the sub-event ends, Sarah is still trying to find video, and she gives a brief description before } \\
\text { she starts playing it. }\end{array}$
\end{tabular}

